UNIVERSIDADE DE SÃO PAULO

FACULDADE DE FILOSOFIA LETRAS E CIÊNCIAS HUMANAS

DEPARTAMENTO DE LETRAS MODERNAS

PROGRAMA DE PÓS-GRADUAÇÃO EM ESTUDOS DA TRADUÇÃO

\title{
ANÁLISE E TRADUÇÃO DE IL VENTRE DI NAPOLI DE MATILDE SERAO
}


UNIVERSIDADE DE SÃO PAULO

FACULDADE DE FILOSOFIA LETRAS E CIÊNCIAS HUMANAS

DEPARTAMENTO DE LETRAS MODERNAS

PROGRAMA DE PÓS-GRADUAÇÃO EM ESTUDOS DA TRADUÇÃO

\section{ANÁLISE E TRADUÇÃO DE IL VENTRE DI NAPOLI DE MATILDE SERAO}

Dissertação apresentada ao Programa de Pós-graduação em Estudos da Tradução do Departamento de Letras Modernas da Faculdade de Filosofia, Letras e Ciências Humanas da Universidade de São Paulo para a obtenção do título de Mestre em Letras

Orientador: Prof. Dr. Maurício Santana Dias

São Paulo

2015 


\section{Agradecimentos}

Ao professor Maurício Santana Dias pela oportunidade em participar do Programa de Pós-graduação em Estudos da Tradução e poder traduzir a obra desta grande autora que é Matilde Serao.

Às professoras Roberta Barni e Cecilia Casini pelas valiosas sugestões apontadas no exame de qualificação.

Às amigas Elizabete Pereira Kutner e Natali Gaudio pelas dicas e pelo incentivo.

Ao colega Nico por ter me ajudado a entender a história da Itália e a Questione Meridionale através de um novo ponto de vista.

A Heder Honório pela tradução do abstract para o inglês e pelas constantes trocas de ideias.

E por fim, agradeço a todos os cidadãos napolitanos que me acolheram com gentileza e generosidade na minha única viagem a Nápoles em janeiro de 2013. Eles me deram a certeza de que havia feito a escolha certa e me fizeram enxergar o termo "ventre" não como a representação daquele emaranhado de becos e ruelas, mas como o retorno a nossas origens. 


\section{ÍNDICE}

$\begin{array}{ll}\text { Introdução } & 7\end{array}$

1- O Sul da Itália no contexto do Risorgimento e da unificação 12

1.1- $\quad$ A Questão Meridional 12

$\begin{array}{ll}\text { 1.2- } & \text { Nápoles e as reformas urbanísticas }\end{array}$

2 - Vida e obra de Matilde Serao 21

3 - Serao e o Verismo 23

3.1 - Características gerais do Verismo 23

3.2 - Outros autores do Naturalismo e do Verismo: semelhanças e diferenças 25

3.3 - As características gerais da obra $O$ ventre de Nápoles 29

4 - Reflexões teóricas sobre a tradução de $O$ ventre de Nápoles 37

$\begin{array}{ll}\text { Conclusão } & 46\end{array}$

Tradução de Il ventre di Napoli

$\begin{array}{lr}\text { Bibliografia } & 135\end{array}$

$\begin{array}{lr}\text { Anexos } & 138\end{array}$ 


\title{
RESUMO
}

Esta dissertação tem como objetivo apresentar uma tradução comentada e anotada para o português brasileiro da obra $I l$ ventre di Napoli, da escritora e jornalista italiana Matilde Serao (1856-1927). O livro está dividido em três partes: Vinte anos atrás, escrito em 1884, Agora, escrito em 1903, e A alma de Nápoles, escrito entre 1903 e 1905.

A introdução à tradução contém ainda uma análise da obra da autora bem como do período histórico em que esta foi escrita.

Palavras-chave: Matilde Serao; literatura italiana; tradução literária; Verismo

\begin{abstract}
This thesis has the purpose of presenting a commented and annotated translation, into Brazilian Portuguese, of the novel Il ventre di Napoli, by the Italian author and journalist Matilde Serao (1856-1927). The book is divided into three parts: Vinte anos atrás [Twenty years ago], written in 1884, Agora [Today], written in 1903, and A alma de Nápoles [The soul of Naples], written between 1903 and 1905.
\end{abstract}

The introduction to the translation also includes an analysis of both the work of the author, and the historical period when it was written.

Keywords: Matilde Serao; Italian literature; literary translation; Verismo

\section{RIASSUNTO}

Questa tesi ha l'obiettivo di presentare una traduzione al portoghese brasiliano, con commenti e note, dell'opera Il ventre di Napoli, della scrittrice e giornalista italiana Matilde Serao (1856-1927). Il libro è diviso in tre parti: Vent'anni fa, scritto nel 1884, Adesso, scritto nel 1903, e L'anima di Napoli, scritto tra il 1903 e il 1905.

L'introduzione alla traduzione contiene sia un'analisi dell'opera della scrittrice che del periodo storico in cui fu scritta.

Parole chiavi: Matilde Serao; letteratura italiana; traduzione letteraria; Verismo 
- Vês esta Nápoles bela, sorridente, voluptuosa com suas colinas floridas, seu mar divino, suas cores esplendorosas? Tu a amas, não é mesmo? - Sim, porque nasci aqui - sussurrou a outra.

- Eu a odeio, com suas ruas cheias de gente, seus perfumes de flores, de carnes, de vinhos espumantes, com suas noites estreladas e provocantes. Odeio porque é a síntese do pecado e da dor. Lá longe, lá longe onde aqueles finos para-raios se elevam no ar, ficam os bairros nobres: lá estão a corrupção e a dor. Aqui embaixo, onde mais casas se amontoam, onde se tornam mais escuras, ficam os bairros populares: corrupção e dor. É pecadora como a cidade de Sodoma, pecadora como Gomorra, é uma mulher pecadora como a Madalena. Mas sente-se torturada em seu pecado, inunda de lágrimas o seu leito, se contorce na noite fatal de Getsêmani. Oh cidade triunfante, maldita e agonizante! $!^{1}$

Napule è mille culure, Napule è mille paure Napule è a voce de' creature che saglie chianu chianu

E tu sai ca nun si sule Napule è nu sole amaro Napule è addore e mare Napule è na carta sporca e nisciuno se ne importa

E ognuno aspetta a 'ciorta Napule è na' camminata, inte e viche miezo all' ato Napule è tutto nu' suonno e a sape tutto 'o munno

Ma nun sann' a verità

(Napul'è , Pino Daniele)

\footnotetext{
${ }^{1}$ Tradução do seguinte trecho do romance Fantasia, de Matilde Serao:

Vedi questa Napoli bella, sorridente, voluttuosa nei suoi colli fioriti, nel suo mare divino, nei suoi colori smaglianti? Tu l'ami nevvero?

— Sì, perchè ci sono nata - disse a bassa voce l'altra.

- Io la odio, nelle sue vie piene di gente, nei suoi profumi di fiori, di carni, di vini spumanti, nelle sue notti stellate e provocanti. La odio perchè è il riassunto del peccato e del dolore. Laggiù, laggiù dove quei parafulmini sottili si elevano nell'aria, sono i quartieri nobili: vi è la corruzione e il dolore. Qui sotto, dove più le case si ammassano, dove più diventano brune, qui sono i quartieri popolari: corruzione e dolore. Essa è peccatrice come la città di Sodoma, peccatrice come Gomorra, essa è donna peccatrice come la Maddalena. Ma si tortura nel suo peccato, inonda di lagrime il suo letto, si torce nella fatale notte di Ghetsemani. O città trionfante, maledetta e agonizzante! (Tradução da autora)
} 


\section{Introdução}

Em 1927, quando morreu Matilde Serao, a cidade de Nápoles parou para acompanhar seu cortejo fúnebre. Em seus setenta e um anos de vida, Serao obteve não apenas o reconhecimento dos napolitanos, mas de inúmeros intelectuais da época, como Gabriele D’Annunzio, Giosuè Carducci, Benedetto Croce, Edith Wharton e até mesmo de Mussolini. (SNYDER, 2012: 1) No prefácio à obra La via della penna e dell'ago, Antonio Ghirelli considera a sua vida um "autêntico milagre artístico e existencial". D’Annunzio dedicou a ela seu segundo romance Giovanni Episcopo (1891) e Carducci a considerava "a maior escritora de prosa da Itália". Em 1924, Mussolini escreveu uma carta a Serao na qual afirmava que havia lido todos os seus livros e que encontrava "muita vida" em sua obra. Entretanto, a simpatia do Duce por sua obra não impediu que a redação do jornal Il Giorno, do qual era diretora, fosse depredado por grupos fascistas. Era admirada até pela norte-americana Edith Wharton, que segundo afirmam, não tinha o hábito de reconhecer o valor de suas colegas escritoras. (SNYDER, 2012: 1)

Essa fama explica-se, pois além de autora de inúmeros livros, que incluíam romances, novelas e contos, foi jornalista e, juntamente com seu marido Edoardo Scarfoglio, fundou o jornal Il Mattino, em 1892, que até hoje é o periódico mais importante do Sul da Itália. Após a separação de Scarfoglio, fundou outro jornal, em 1904: Il Giorno, que continuou existindo por algum tempo depois de sua morte.

A trajetória de sua vida foi peculiar e está relacionada à própria história da Itália. Nasceu em 1856, na ilha de Patras, na Grécia, onde seu pai, favorável à Unificação da Itália, havia se refugiado. Entretanto, após a proclamação do Reino da Itália, em 1861, retornou com sua família a Nápoles, onde passaria praticamente toda sua vida e viria a falecer em 1927.

Embora sua família fosse de origem modesta, teve acesso à educação, o que não era comum para as mulheres da época. Durante a juventude, foi funcionária dos telégrafos, trabalho que abandonou em 1877 para dedicar-se à carreira jornalística.

Em 1885, casou-se com o também jornalista Edoardo Scarfoglio, com quem teve quatro filhos. O casal fundou, em março de 1892, o jornal Il Mattino, para o qual colaboravam também Gabriele D’Annunzio e Francesco Saverio Nitti. Entretanto, 
vários acontecimentos tornaram a vida do casal atribulada e, consequentemente, alvo de comentários nas crônicas da época. O primeiro caso no qual se envolveram foi a Investigação Saredo, que tinha como objetivo elucidar a atuação da chamada "camorra administrativa", ou seja, a situação de corrupção e clientelismo que assolava a prefeitura da cidade de Nápoles, nas duas últimas décadas do século XIX, segundo denúncias do jornal socialista La Propaganda. Scarfoglio foi acusado de ter recebido dinheiro para escrever artigos em defesa dos acusados no processo.

O segundo caso diz respeito à vida privada do casal. Entre suas muitas aventuras extraconjugais, Scarfoglio envolveu-se com a cantora francesa Gabrielle Bessard, com quem teve um filho. Em 1894, a jovem, desesperada com o abandono do amante, suicidou-se diante da casa de Serao e Scarfoglio, deixando a criança aos cuidados deles. Algum tempo depois, Serao separou-se definitivamente do marido, o que marcou também o fim da parceria profissional.

Todos esses episódios de sua vida privada e os consequentes comentários acabaram deixando de lado, por um certo período, o imenso legado de Matilde Serao tanto para a literatura e para o jornalismo quanto para a história da emancipação feminina.

Apesar da importância e do reconhecimento de sua obra na Itália e da forte presença italiana no Brasil, que sempre demonstrou interesse na cultura italiana de um modo geral, a tradução de Matilde Serao é escassa em português: além do conto Uma florista, presente em uma coletânea de contos italianos, ${ }^{2}$ temos o apenas o romance Adeus, amor. ${ }^{3}$

A presente dissertação pretende cobrir esta lacuna com a apresentação da tradução de uma de suas obras mais renomadas, $O$ ventre de Nápoles, que possui uma estrutura bastante peculiar. Está dividida em três partes: Vinte anos atrás, escrito em 1884, Agora, escrito em 1903, e A alma de Nápoles, escrito entre 1903 e 1905. Vale lembrar que o título da obra faz referência ao romance $O$ ventre de Paris, de Émile

2 CAVAlHEIRO, E. Maravilhas do Conto italiano. Introdução e notas de Edgard Cavalheiro; Organização Diaulas Riedel; Seleção: Aldo Bagnotti. São Paulo: Editora Cultrix, 1963. O nome do tradutor não é mencionado.

${ }^{3}$ SERAO, Matilde. Adeus, amor! Porto Alegre: Livraria do Globo, 1924. O nome do tradutor não é mencionado. 
Zola, cujo estilo influenciou fortemente Serao. Embora se trate de uma coletânea de artigos escritos para serem publicados em jornais, não pode ser classificada como uma reportagem. Trata-se de uma obra híbrida, como destaca Giuseppe Montesano:

Nel Ventre di Napoli la Serao buttava a cuocere nella stessa pentola sondaggio sociologico e choses vues alla Hugo, lacerto narrativo e saggio di costume, appello al lettore e ritratto dal vero, inchiesta giornalistica e schizzo antropologico, secondo una tecnica che può essere accostata a un dissestato montaggio stilistico. (MONTESANO, 2008: 13)

A primeira parte da obra, escrita logo após a epidemia de cólera que se abateu sobre a cidade, traz a descrição da situação de miséria da população. Trata-se de uma resposta ao ministro do Interior Agostino Depretis que afirmara ser necessário "sventrare Napoli". A segunda parte é predominantemente dedicada às críticas da reforma urbanística empreendida pelo governo, que, de acordo com Serao, apenas serviram para ocultar a pobreza e não atacaram a verdadeira causa dos problemas da cidade. A terceira parte, visivelmente inspirada no cristianismo de Tolstoi, exalta a filantropia de políticos e personalidades de Nápoles, mostrando como esta poderia ser uma solução para a cidade.

Benedetto Croce, grande admirador de Serao, assim define a obra:

(...) pagine tirate d'un fiato, descrizioni rapide, aneddoti narrati con semplicità, calorosa eloquentissima perorazione a pro del popolo napoletano, piena di quell'affetto materno del quale ella possiede il segreto... E io confesso di preferire i bozzetti e le novelle, e fin gli articoli del Ventre di Napoli, scorretti e quasi improvvisati ma spontanei, al quadro sapiente, ch'è troppo sapiente, del Paese di Cuccagna. (CROCE apud BIANCHI, 2008: 24)

Seguindo uma linha de pensamento semelhante à de Croce, Patricia Bianchi, em sua introdução à edição de 2008 de $I l$ ventre di Napoli, afirma que Serao, "mesmo entre seus desníveis linguísticos entre o velho e o novo vai em busca de uma opção estilística original”. (BIANCHI, 2008: 31) Destaca também que a principal diferença entre suas obras anteriores e Il ventre é justamente a inserção de termos dialetais e populares, que hoje já são conhecidos em outras regiões da Itália. Toda a produção literária e jornalística de Serao tem, porém, uma característica em comum: o uso inapropriado da pontuação, já que boa parte de suas obras não passava por revisão. (BIANCHI, 2008: 30) 
Além das escolhas linguísticas, Bianchi esmiúça como foi feita a publicação da obra. A primeira parte, que inclui os nove artigos publicados no jornal "Capitan Fracassa" de Roma, foi publicada inicialmente em dezembro de 1884, em Milão. Em 1906, surge a segunda edição, com o acréscimo dos artigos de Agora e de A alma de Nápoles, que já haviam sido publicados no periódico napolitano "La settimana. Rassegna di arti, lettere e scienze", entre 1903 e 1905. A versão utilizada para a tradução aqui apresentada é a segunda edição, publicada pelo editor Francesco Perrella, de Nápoles. Nessa edição, disponibilizada pelo site www.liberliber.it, foram mantidos asteriscos para marcar as divisões entre os diferentes artigos, ao contrário da edição impressa de 2008, que manteve apenas a divisão em capítulos. Na tradução, foram mantidos os asteriscos.

Diante do desafio que representa a tradução de uma obra de tal complexidade, as reflexões de Aubert em As (in)fidelidades da tradução, sobretudo em relação aos referentes e às dimensões temporais, têm sido de fundamental importância. Levando-se em conta que a obra em questão foi escrita há mais de um século e se concentra na descrição da realidade de um espaço bem delimitado (a cidade de Nápoles), é importante analisar o "grau de amarração" do texto, ou seja, resgatar o referente de partida e buscar seus equivalentes na língua/cultura de chegada (AUBERT, 1993). Isso se revela particularmente importante, por exemplo, quando nos defrontamos com os nomes de profissões, atividades ou costumes dos habitantes de Nápoles, como ficará explicitado nos exemplos apresentados.

Deve-se mencionar também que o conceito de "negociação", apresentado por Umberto Eco, foi um dos norteadores deste trabalho. Com este termo, Eco refere-se a diversas questões cruciais para a teoria da tradução, como a "fidelidade" à obra de partida e a iniciativa do tradutor. (ECO, 2003: 17)

Uma característica importante que foi levada em conta no processo de tradução é a presença constante de elementos típicos da oralidade. Como o livro foi escrito como resposta à declaração do Ministro do Interior Agostino Depretis ${ }^{4}$ que afirmou, em 1884, ser necessário "sventrare Napoli" para combater a epidemia de cólera, em vários momentos a autora dirige-se diretamente a ele, como já fica evidente na abertura da

\footnotetext{
${ }^{4}$ Agostino Depretis (1813-1887) - foi por nove vezes presidente do Conselho de Ministros do Reino da Itália. Na época em que Serao escreveu $O$ Ventre de Nápoles, Depretis era Ministro do Interior.
} 
obra. Patrícia Bianchi destaca que os recursos da oralidade estão presentes também no uso recorrente de verbos no imperativo (Esagerate venti volte quello che vi ho detto) ou em constantes perguntas dirigidas aos leitores.

O fato de a tradução estar voltada para a leitura do público contemporâneo não significa que o texto final resultará em uma simplificação ou em um apagamento das características do texto original.

Por fim, a questão da recorrência de termos e frases em dialeto merece algumas considerações. Snyder, tradutor para o inglês de $O$ ventre de Nápoles, chama a atenção para o fato de que "frequentemente a frase precedente ou seguinte ao termo dialetal é uma perífrase ou contém informações suficientes que permitem ao leitor saber seu significado”. (SNYDER, 2012: 6) Mesmo assim, na tradução para o português optou-se pela manutenção do termo em itálico (como está no texto de partida) e a inserção de notas de rodapé com a tradução. 


\section{1- O Sul da Itália no contexto do Risorgimento e da unificação}

\section{1- A Questão Meridional}

As diferenças culturais e econômicas entre o Norte e o Sul da Itália ainda são bastante visíveis nos dias de hoje. O estudo do que se convencionou chamar de Questione Meridionale começou logo após a Unificação, em 1861, quando os contrastes tornaram-se mais evidentes. A preocupação com a miséria de uma população que ficou à margem do processo de desenvolvimento econômico que se observava principalmente no Norte teve seus reflexos na literatura já em meados do Ottocento: as obras veristas dos sicilianos Giovanni Verga e Luigi Capuana estão entre as mais conhecidas. Matilde Serao, embora tenha características próprias que serão analisadas nos capítulos seguintes, também segue essa tendência.

Buscando entender a origem e uma possível solução para o problema, pensadores e intelectuais italianos dedicaram muitas obras ao tema. Entre eles destacam-se o sardo Antonio Gramsci, os lucanos Giustino Fortunato e Francesco Saverio Nitti e o pugliese Gaetano Salvemini.

Segundo Gramsci, enquanto o poder político do Norte esteve baseado nas Comuni, ou seja, em cidades autônomas, o Sul foi governado por sucessivos reinos: dos suábios, dos Anjou, dos espanhóis e dos Bourbons. Com a unificação, todas essas diferenças vieram à tona e as consequências foram imediatas: migração do capital do Mezzogiorno para o Norte, onde seria empregado na indústria que começava a se desenvolver, e migração dos habitantes, que buscavam trabalho em outros países. $\mathrm{O}$ Brasil, por exemplo, recebeu cerca de um milhão e duzentos mil imigrantes italianos entre 1876 e 1920, dos quais aproximadamente quinhentos mil eram provenientes de regiões meridionais (os números mais expressivos eram da Campânia, seguida da Calábria, Basilicata, Sicília, Puglia e Sardenha). (VIEIRA, 2011: 14)

Gramsci apontava ainda que a única solução possível para a Questione Meridionale era a revolução comunista, com a união entre os operários das fábricas e os camponeses: "Il proletariato settentrionale, emancipando se stesso dalla schiavitù capitalistica, emanciperà le masse contadine meridionali asservite alla banca e all'industrialismo parassitario del settentrione." (GRAMSCI, 1966: 11) 
Giustino Fortunato, nascido em 1848, em Rionero in Vulture, província de Potenza, enfatizava em sua abordagem os aspectos econômicos, geográficos e históricos do Sul e, diversamente de Gramsci, sempre refutou o meridionalismo revolucionário e temia uma revolta camponesa. Tendo isso em vista, fez de sua obra uma constante "advertência para que as classes dirigentes não se afastassem do fio condutor que finalmente levaria finalmente o país à modernidade". (MANCINO, 1999: 15) Embora evidenciasse a importância dos fatores geográficos desfavoráveis no atraso econômico do Sul, não deixou de lado causas históricas e políticas. Segundo ele, a Itália meridional "permaneceu organizada feudalmente, embora o feudo, em um primeiro momento politicamente, e em um segundo momento, juridicamente tendesse a desaparecer". (MANCINO, 1999: 16)

Francesco Saverio Nitti, nascido em Melfi, província de Potenza, em 1868, além de ter deixado inúmeras obras sobre economia e finanças, foi eleito deputado em 1904. Em sua análise sobre a questão urbanística napolitana, rejeitava a ideia de que o turismo poderia ser uma solução para os problemas da cidade e apontava a necessidade de desenvolvimento industrial, que seria alcançado através de uma adequada política de investimentos. Vale lembrar que Matilde Serao era uma das defensoras do turismo como fonte de recursos para Nápoles, ideia aprofundada no artigo "O que fazer?" da terceira parte de $O$ ventre de Nápoles.

As diferenças entre o Norte e o Sul da Itália também foram analisadas à luz de ideias baseadas no racismo científico que começava a ganhar força no final do século XIX na Europa. Um episódio relatado por Serao ajuda a explicar melhor o fato: ao falar sobre o hábito napolitano de jogar na loteria, a autora afirma que qualquer acontecimento cotidiano poderia sugerir números para os supersticiosos que acreditavam na Smorfia, a arte napolitana de interpretar sonhos e situações da vida real. Em seguida, menciona episódios da crônica policial da época que haviam inspirado números, entre eles o de Salvatore Misdea, que havia assassinado sete soldados.

Misdea era um soldado calabrês que servia em um quartel de Nápoles. Em 13 de abril de 1884, disparou contra seus companheiros, matando oito e ferindo treze. Alguns meses mais tarde, foi condenado à morte por fuzilamento. Segundo os relatos, Misdea, cansado das constantes ofensas por sua origem calabresa, decidiu vingar-se de seus companheiros. O médico Cesare Lombroso, considerado o fundador da criminologia 
científica, participou de seu processo defendendo a tese de que ele era um criminoso nato, relacionando suas características físicas a seu caráter, que de acordo com o cientista, era agressivo e desejoso de vingança: assimetria do crânio ("típica dos delinquentes natos"), a forma do maxilar ("típica dos loucos") e a distância dos dentes, ("típica das raças africanas e dos macacos"). As teorias de Lombroso foram fundamentais para a condenação à morte de Misdea. Na mesma direção de Lombroso, estavam as teorias de Alfredo Niceforo, que afirmava que duas "estirpes muito distintas habitavam a Itália": uma no Norte e outra no Sul. Ambos tiveram bastante influência na época em que viveram. (DANIELE, 2010: 1)

Em relação a essa vertente de cunho evidentemente racista, Gaetano Salvemini (1955: 60) afirmava:

Nego assolutamente che il carattere dei meridionali diverso da quello dei settentrionali abbia alcuna parte nella diversità di sviluppo dei due paesi. Spiegare la storia di un paese con la parola razza è da poltroni e da semplicisti.

Quando se fala sobre o Sul durante o Risorgimento não se pode deixar de lado a questão do brigantaggio. A miséria e o estado de abandono da população camponesa do Sul da Itália são as principais causas que explicam esse complexo fenômeno, caracterizado pela existência de grupos armados com os mais diversos objetivos, que incluíam desde saques e roubos até a luta contra o poder recém instituído do Reino da Itália. Reunia camponeses, ex-militares do Exército Borbônico ou aqueles que se recusavam a alistar-se no Exército Nacional e contava inicialmente com amplo apoio da população. Entre 1861 e 1865, várias províncias foram palcos de sangrentas lutas entre os briganti e o governo, o que acabou culminando na violenta repressão realizada pelo general Enrico Cialdini. Enviado a Nápoles com poderes excepcionais, o militar chegou a contar com uma tropa de cento e cinquenta mil homens, o que representava dois quintos das forças armadas italianas da época, e foi responsável pelo massacre de milhares de camponeses. Calcula-se que em cerca de dez anos de combates contra os grupos de briganti, morreram em torno de vinte mil pessoas. (CALICE, 2000, p.30)

Além de tudo o que foi exposto não podemos deixar de lado a questão da religião, que ocupa um papel central em $O$ ventre de Nápoles. O antropólogo Ernesto de Martino (DE MARTINO,1982), em seu ensaio Sud e Magia, nos mostra como as condições históricas fizeram surgir no Sul da Itália um tipo de religiosidade 
extremamente peculiar, onde a tradição cristã se mescla a superstições populares e ritos pagãos. Estudando a jettatura, ele explica que

Or questa perdurante potenza del negativo si traduce, dal punto di vista esistenziale, nella ricorrente esperienza della precarietà dei beni vitali elementari, nella insicurezza delle prospettive, nel caos di cozzanti interessi particolaristici e individualistici, e in generale nell'ininterrotta pressione di forze non dominabili - naturali o sociali che siano - prementi da tutte le parti e schiaccianti l'individuo senza che la cultura nel suo complesso e la società nella sua tessitura offrano la possibilità di comportamenti realistici efficaci per fronteggiare il negativo e ridurlo a misura umana. Ora proprio qui si inserisce il particolare rilievo che assumono, nel sud, il ricorso alle tecniche protettive della bassa magia, la accentuazione magica del cattolicesimo, la molteplicità dei raccordi intermedi magico-religiosi, il largo spirito di compromesso, la scarsa capacità d'espansione della cultura di vertice; (DE MARTINO,1982: 165)

Todas estas questões criaram um universo peculiar, que Matilde Serao soube captar com habilidade, como poderá ser percebido na tradução anexa. Ela faz constantes referências à jettatura, que segundo De Martino, originou-se de uma combinação de uma antiga tradição de magia com o racionalismo iluminístico.

A explicação de Serao está muito próxima à citação de De Martino: é a falta de perspectivas que induz o napolitano a acreditar no sobrenatural e apegar-se a sortilégios e superstições:

Exagere vinte vezes tudo o que lhe disse: talvez, não fosse verdade. Esta mistura confusa de fé e engano, de misticismo e sensualidade, este culto externo tão pagão, esta idolatria, o assustam? Lamenta estas coisas, dignas dos selvagens? Mas quem fez algo pela consciência do povo napolitano? Quais ensinamentos, quais palavras, quais exemplos pensou-se em dar a esta gente tão expansiva, tão fácil de conquistar, tão naturalmente entusiasta? $\mathrm{Na}$ verdade, em meio à miséria profunda da sua vida real, eles não tiveram outro conforto a não ser as ilusões da própria fantasia e outro refúgio além de Deus.

O ventre de Nápoles também pode ser considerada, como já se disse, uma obra de fundamental importância para o estudo da Questão Meridional. Entretanto, ao contrário dos autores citados, Serao não busca explicações para os problemas da cidade, mas dedica-se sobretudo, como cronista, a descrever a situação de pobreza da população e, em alguns momentos, propõe soluções ou critica o descaso do governo. Não enxerga a Questão Meridional sob uma ótica revolucionária, como Gramsci, e mantém uma posição conservadora principalmente em relação às desigualdades sociais: um exemplo disso é um dos últimos artigos intitulado "Cristo diz...", no qual deixa claro que "ricos e pobres sempre existirão". Além disso, Serao não analisa o Mezzogiorno como um todo, mas concentra-se na cidade de Nápoles, que é sempre o personagem principal de toda sua obra. 


\subsection{Nápoles e as reformas urbanísticas}

Nápoles é uma das cidades mais antigas da Europa, fundada no século VIII a.C., e que preserva no traçado das ruas e nas construções elementos de sua longa história e dos diferentes povos que a governaram. Seu centro histórico é considerado, desde 1995, Patrimônio Cultural da Humanidade pela UNESCO, e possui uma área de aproximadamente $17 \mathrm{~km}^{2}$ que conserva o traçado viário da época grega. Os chamados decumani (plateia em grego), que atravessam a cidade de leste a oeste, paralelamente ao mar, são a Via dei Tribunali (decumano maior), San Biagio dei Librai (decumano inferior) e Via della Sapienza, Via dell'Anticaglia e via Santi Apostoli (decumano superior). Essas ruas são cortadas de norte a sul pelos chamados cardini (stenopoi em grego), dentre os quais se destaca a Via del Duomo, a que mais sofreu modificações durante as reformas urbanísticas do final do século XIX. ${ }^{5}$

Durante a Idade Média, a cidade foi governada pelos reis normandos, dentre os quais o mais célebre foi Federico II, responsável pela fundação, em 1224, da universidade que leva seu nome.

Em 1861, quando foi proclamado o Reino da Itália, Nápoles era a cidade mais populosa da Itália, com cerca de 450 mil habitantes. Havia sido capital do Reino das Duas Sicílias, que ocupava praticamente metade do território atual da Itália. Em 1734, após um longo domínio espanhol, Carlos de Bourbon assume o trono do Reino de Nápoles e da Sicília. Apenas em 1816 o Reino adquire o nome de Reino das Duas Sicílias. Durante o período borbônico, a cidade conheceu um grande desenvolvimento socioeconômico e foi palco de muitos avanços tecnológicos, inclusive da construção da primeira ferrovia da Itália, em 1839. As guerras de unificação, porém, foram particularmente prejudiciais aos camponeses do Sul: o derramamento de sangue, a devastação da lavoura e o aumento da miséria tiveram como consequência o início do processo de emigração da população.

A situação nas cidades, no entanto, não era melhor. Serao destaca a epidemia de cólera de 1884 em Nápoles, que despertou a necessidade de elaborar um novo projeto urbanístico para a cidade.

\footnotetext{
${ }^{5}$ Nos Anexos encontramos dois mapas do centro histórico de Nápoles. Comparando o primeiro, de 1800 , e o segundo, atual, podem ser vistas algumas das transformações pelas quais passaram as ruas durante $o$ "sventramento" promovido pelo governo de Agostino Depretis.
} 
De fato, nesse período, a urbanização e os problemas decorrentes disso eram amplamente discutidos em todo o mundo. Buscando controlar o acelerado crescimento de algumas dessas cidades, projetos urbanísticos foram colocados em prática em diversas partes do mundo, como em Paris e no Rio de Janeiro.

Como afirma Maria Stela Brescianni (1982: 9) em sua obra sobre Londres e Paris no final do século XIX, com o constante crescimento populacional, as massas humanas que viviam em condições insalubres e o espetáculo da pobreza despertavam ao mesmo tempo "admiração e temor". Diante disso, tornava-se necessária a criação de estratégias de controle social.

Nesse mesmo período, ocorria, em todo o mundo, um acelerado desenvolvimento científico e tecnológico. E é justamente nesse contexto que surge a "utopia higienista" que propunha novas formas de abordagem do espaço urbano em função das teorias médicas então dominantes na Europa. De acordo com essa mentalidade, a população pobre oferecia perigo não só pela possibilidade de contestação à ordem social, mas também pelo risco de contágio de doenças. (SOARES, 2013: 5) Seria portanto necessário disciplinar essa população tendo como base critérios médicos.

A aglomeração de um grande número de pessoas em casas que muitas vezes possuíam apenas um cômodo era vista como um incentivo aos vícios e considerada uma ameaça à moral e aos costumes cristãos, como destacado em várias passagens por Serao:

Certamente não será possível manter em pé as casas, onde se aglomeram em pequenos quartos ao menos quatro pessoas, além de galinhas, pombos, gatos esfomeados e cães sarnentos; onde as pessoas cozinham em cubículos, comem no quarto e morrem no mesmo cômodo em que os outros dormem e comem;

Mesmo alguns anos após a reurbanização realizada pelo governo e a construção de casas populares, o problema persistia e a autora deixa evidente mais uma vez a preocupação com a promiscuidade resultante da concentração de muitas pessoas em cubículos:

Então, encontra-se o pior e melhor remédio: duas famílias em uma casa de vinte e sete liras, apertadas, apertadas, três ou quatro ocupando um quarto, com uma pequena cozinha comum e assim, adeus ar, adeus luz, adeus higiene! Frequentemente uma família subloca um quarto a estudantes, a homens sozinhos e a vida é comum e tanto no primeiro, como no segundo caso a aglomeração, os contatos, o viver uns sobre os outros, conduz, novamente, à sujeira, à doença, ao vício, à corrupção e à depravação. 
Antes disso, entre 1851 e 1870, em Paris, durante o governo de Napoleão III, o prefeito Haussman empreendeu uma reforma na cidade que transformou o antigo traçado tortuoso das ruas e abriu longas avenidas. Os críticos da reforma afirmavam que a "nova" cidade que surgiu era uma criação artificial e estava distante da realidade e do dinamismo da população que circulava pelo espaço urbano.

A epidemia de cólera que dizimou boa parte da população napolitana levou o Ministro Agostino Depretis a pronunciar a célebre frase, que gerou duras críticas de Matilde Serao: Bisogna sventrare Napoli (É preciso desventrar Nápoles).

Levado adiante pelo prefeito Nicola Amore, o projeto de saneamento foi aprovado em 1885 e três anos mais tarde foi fundada a Sociedade para o Saneamento de Nápoles. Inúmeros edifícios históricos foram destruídos para a construção do Corso Umberto I, das praças Nicola Amore e Borsa. Além desses logradouros, foi construída a Galleria Umberto I, em um dos bairros mais duramente atingidos pelas epidemias de cólera entre 1835 e 1884 . A construção do edifício, que até hoje abriga lojas, cafés e restaurantes, deu-se em uma região da cidade que, embora estivesse degradada, estava bastante próxima de outros edifícios importantes: o Palácio Real, a Igreja de São Francisco de Paula e o Maschio Angioino, bem como da Rua Toledo, considerada por Serao como a rua mais importante da cidade, uma "profunda e palpitante artéria" na qual se desenrolaram os acontecimentos mais marcantes da história de Nápoles. (Ver Anexo 6)

Na segunda parte de $O$ ventre de Nápoles, intitulada Agora, escrita em 1903, a autora já descreve as primeiras impressões sobre as reformas urbanísticas empreendidas na cidade. Mais uma vez, as críticas são inúmeras. De um modo geral, ela afirma que a reforma tivera um objetivo puramente estético, mas esse efeito fora obtido apenas parcialmente, pois para quem olhasse com atenção as novas avenidas abertas, que partiam justamente da estação de trem, e os edifícios recém-construídos, veria que por trás deles surgiam "massas de casas imundas, decadentes, miseráveis, de todos os tamanhos, marcadas por todas as chagas da pobreza e do vício". O objetivo de promover saneamento também não fora alcançado: segundo Serao, a nova avenida ${ }^{6}$ servia apenas como um frágil "biombo" que apenas escondia a mesma situação de miséria e criminalidade a que estava sujeita a população vinte anos antes.

\footnotetext{
${ }^{6}$ Atual Corso Umberto I.
} 
O cronista João do Rio e o escritor Lima Barreto, que acompanharam as reformas urbanísticas no Rio de Janeiro, têm uma visão bastante semelhante à de Serao. Lima Barreto destaca em suas crônicas que a reforma que ficou conhecida como "Bota Abaixo" e que desalojara a população de baixa renda de seus cortiços na então capital do Brasil servia apenas aos interesses da elite econômica, buscando embelezar a cidade, com a construção de largas avenidas e suntuosos edifícios como nas capitais europeias, sem atender às demandas por melhoria das condições de moradia e saneamento.

Assim como os cronistas brasileiros, Serao destaca o drama das pessoas desalojadas de forma arbitrária de suas casas e que não têm sequer condições de pagar o aluguel das casas populares que estavam sendo construídas:

Preferiram, obstinadamente, suas velhas, destruídas e imundas casas que, por dezoito anos, esperaram a picareta, pela qual pagavam nove ou dez liras por mês de aluguel - é TUDO o que pode pagar o povo napolitano NOVE ou DEZ LIRAS por mês! - e nos últimos dois anos, pouco a pouco recuaram, dirigindo-se às mesmas espeluncas, e expulsos pelas demolições, retornaram, retornam à noite para morar nas ruínas, e ficam de joelhos diante dos demolidores, para não serem perseguidos pelos guardas, pelos policiais, e choram, e gritam, fazem escândalo, não querem ir embora, não sabem ir embora, e alguns deles, oh misericórdia, moram, agora, nas grutas sob o monte Echia ${ }^{7}$ que se eleva sobre santa Luzia, e às vezes uma destas grutas desmorona sobre as cabeças, sobre os corpos destes miseráveis lucianos que dormem, e os mata.

Vemos, portanto, que embora discordasse do projeto higienista que colocou em prática a reforma urbanística e criticasse os seus resultados, Serao compartilhava da crença científica dominante na época, segundo a qual a tendência do indivíduo é o resultado do meio em que vive:

Povo: povo verdadeiro, numeroso, obscuro, em multidões temíveis, cujos rostos mostram os cansaços e as tristezas, com vozes roucas, enfraquecidas pela fome e pelas doenças, com os germes hereditários que um atavismo, ah, de pobreza, aqui colocou, com os instintos do mal exaltados pela longa existência de misérias, e de pranto, com a inclinação ao mal sim, ao mal, que aqui colocou este centenário e cruel abandono obstinado da sua infeliz sorte

Ela reivindicava, porém, transparência nos gastos públicos e alegava que apenas a abertura de uma avenida e a construção de jardins públicos e chafarizes não eram suficientes para mudar a realidade da cidade:

Tenho diante dos olhos e espero poder comunicar, sempre que for o caso, um elenco de projetos, de propostas, de coisas feitas pela metade ou a se fazer, onde os gastos, às vezes inúteis, às vezes extravagantes, quase sempre imprudentes, são altíssimos. Eu não

\footnotetext{
${ }^{7}$ Primeiro núcleo habitado da cidade de Nápoles, cuja história remonta ao século VIII a.C.
} 
sou a tutora da Prefeitura, graças a Deus, e nem você, amigo leitor, para sua sorte: mas algum soldo, destes milhões, é seu e meu. Interessemo-nos por estes poucos centavos, teus, meus, leitor, porque são uma parte destes milhões.

A questão das reformas urbanísticas é o tema principal dos artigos das duas primeiras partes do livro. Já na terceira parte, “A alma de Nápoles”, a questão deixa de ser discutida e Serao dedica-se a outros temas, mas sempre girando em torno do cotidiano da parcela mais pobre da população napolitana. 


\section{2 - Vida e obra de Matilde Serao}

Segundo Cristine Farruggia (2005: 17), a maioria dos críticos considera que a obra de Matilde Sero pode ser dividida em quatro fases: no início, seus contos e novelas descrevem sobretudo a pequena burguesia napolitana e ainda apresentam características do Romantismo. Na segunda, da qual fazem parte Il ventre di Napoli e Il Paese di Cuccagna, adere ao Verismo e fica evidente a influência da linguagem jornalística em sua obra. Posteriormente, dedica-se a romances de tendência "psicológico-espiritual" inspirada no francês Paul Bourget ${ }^{8}$. E, por fim, retorna ao Verismo, mas, segundo os críticos, não consegue compor obras comparáveis às já citadas.

A primeira obra narrativa de Matilde Serao, intitulada Opale, publicada em 1878 sob o pseudônimo Tuffolina, ainda estava ligada ao Romantismo. Narra a história de Filippo, que busca dar sentido a sua vida através de uma relação amorosa com Claudia. A narrativa se conclui com o suicídio da jovem em um lago. Dessa fase também podese destacar a coletânea de novelas Dal vero (1879), na qual já se delineiam alguns dos elementos que seriam marcantes nas obras posteriores, como por exemplo a descrição do cotidiano da parcela mais pobre da população de Nápoles. Leggende Napoletane, publicado em 1881, embora faça parte da fase considerada romântica e seja uma obra de cunho fantástico, baseada na imaginação, mostra "a beleza da paisagem em contraposição à indiferença dos homens". (FARRUGIA, 2005: 38)

A fase verista de Serao inaugura-se com a publicação do romance Cuore infermo no jornal La Stampa, de Turim, em 1881. A partir de então, as técnicas aprendidas em sua carreira de jornalista ("a cordialidade expressiva, a capacidade de observação, a habilidade de reconstruir ambientes e situações, a fusão de destaque realista com participação emotiva") estarão cada vez mais presentes em sua narrativa. (FARRUGIA, 2005: 51). Para isso contribui de forma significativa sua permanência em Roma, entre 1882 e 1888, quando trabalhou ativamente no jornalismo, como redatora do Capitan Fracassa e colaboradora da Nuova Antologia, da Domenica Letteraria e da Cronaca Bizantina.

\footnotetext{
${ }^{8}$ Escritor francês (1852-1935). Contrário ao Naturalismo e ao Racionalismo, tendências dominantes na época, foi autor de romances que discutiam problemáticas espirituais como Le sens de la mort e Nos actes nous suivent. Politicamente, aproximou-se do movimento Action Française, que defendia a volta da monarquia.
} 
Dessa fase, destacam-se ainda Piccole anime (1883), cujo tema central é a infância, bem como Fantasia (1883), que contrapõe duas personagens femininas que revelam muito sobre a visão conservadora de Serao sobre a posição da mulher na sociedade: Lucia, jovem voluntariosa e sonhadora, e Caterina, submissa e ligada à família. A amizade que mantinham desde os tempos do colégio não impediu que Lucia seduzisse o marido de Caterina que, transtornada com a traição, acabou se suicidando. O romance foi bem recebido, mas foi alvo de duras críticas por parte de Edoardo Scarfoglio, seu marido, que alegava uma forte influência francesa, sobretudo de Madame Bovary, de Flaubert. (FARRUGIA, 2005: 67)

Mas as obras consideradas pelos críticos como as mais representativas do Verismo de Serao são, sem dúvida, Il ventre di Napoli e Il paese di Cuccagna. Este último, publicado em 1890, foi fruto de grande empenho literário e trata da paixão dos napolitanos pelo jogo da loto, que muitas vezes traz como consequência ruína e desgraça.

Na primeira década do século XX, Serao afasta-se do Verismo e, seguindo a influência do francês Paul Bourget, adere a uma tendência espiritualística e recebe por isso muitas críticas negativas. Nessa fase, compôs Addio, amore! (1890), que alcançou enorme sucesso, inclusive no exterior, bem como Gli amanti e Le amanti, que são coletâneas de histórias de amor sob uma "ótica sensual e idealista” (FARRUGIA, 2005: 298).

Posteriormente, retoma algumas características do Verismo, como a minuciosa descrição do ambiente e a perspectiva coral, com as obras La ballerina (1899), Suor Giovanna della Croce (1901) e Storie di due anime (1904).

Em relação ao posicionamento político, Serao inicialmente tentou aproximar-se de Mussolini. Entretanto, logo em seguida seu jornal Il Giorno iniciou uma campanha antifascista, que provocou seu afastamento definitivo do Duce. Como consequência, não foi indicada para o Nobel de Literatura, que acabou sendo entregue a Grazia Deledda, em 1926. (FARRUGIA, 2005: 299). Nesse mesmo ano, Serao publica Mors tua, na qual denuncia o nacionalismo militarista que, segundo ela, sacrifica os povos em nome de guerras que servem a interesses políticos. 


\section{3 - Serao e o Verismo}

\section{1 - Características gerais do Verismo}

O Naturalismo narrativo é o resultado de um movimento de escritores, dentre os quais se destaca Zola, na França, que se esforçavam em utilizar as premissas da ciência positivista na elaboração de romances. Na década de 1860, Zola publicou a obra Thérèse Raquin, na qual apresenta uma análise detalhada de um personagem feminino, e em seguida inicia a série de romances Rougon-Macquart, que tratam sobre a história de uma família. Em 1880, publica o ensaio $O$ romance experimental, no qual define o método narrativo naturalista. O naturalismo de Zola é "laico, democrático e progressista, e visa, através da realidade social, a uma melhoria das condições de vida". (FERRONI, 2008: 57)

$\mathrm{Na}$ mesma época, essas novas tendências também se faziam sentir na Itália. Autores como Dall'Ongaro e Carducci e movimentos como a Scapigliatura afastam-se do romantismo e do realismo moderado de Manzoni e buscam novos caminhos literários. Já por volta de 1860, o termo Verismo começa a ser usado, para designar uma literatura que se aproximava do "verdadeiro". (FERRONI, 2008: 57) Enquanto na França, os escritores focalizavam o cotidiano de miséria dos trabalhadores urbanos, na Itália os principais narradores do Verismo concentravam-se na vida rural. (FARRUGIA, 2005: 44)

Croce define o Verismo como um movimento histórico que se desenvolveu na metade do século XIX em correlação com o desenvolvimento das ciências naturais, psicológicas e sociológicas. (CROCE, 1943: 12) Ao contrário de outros críticos, ele não considera o Verismo italiano uma simples "imitação exótica" das manifestações literárias que ocorriam na França e na Inglaterra naquele período:

Il verismo si affermò in Italia, perché l'Italia partecipava alla vita moderna; e se venne preceduto da quello francese e inglese e ne risentì l'influsso, questo fatto indica bensì la situazione storica in cui esso sorse, ma non designa punto l'inferiorità del suo valore artistico. (CROCE, 1943: 14)

Segundo Pellini, assim como "naturalismo", o termo verismo foi usado em uma ampla gama de acepções, incluindo todas as obras italianas inspiradas nos métodos de Zola e Flaubert. De forma mais restrita, em referência às obras de Capuana, Verga e De Roberto. (PELLINI, 2010: 10) 
Em meados do Ottocento, os centros culturais mais ativos da Itália eram Florença, cujo cenário era caracterizado por um "realismo moderado", e Milão, a cidade que estava assumindo o papel preponderante do ponto de vista econômico e editorial. Já no Sul do país, as condições eram bem diferentes:

Se le condizioni particolari della Sicilia stimolavano la grande narrativa verista in altre zone del Mezzogiorno (e in primo luogo a Napoli, che aveva perduto il suo ruolo di capitale del regno borbonico) si sviluppava una narrativa meno rigorosa, ma comunque incline a osservare la realtà locale in modo nuovo, a rivelarne la diversità rispetto alle condizioni del resto del paese, a mostrare la sua irriducibilità a un modello nazionale omogeneo e unitario. (FERRONI, 2008: 94)

Não por acaso, são os sicilianos Giovanni Verga e Luigi Capuana os nomes mais conhecidos do Verismo na Itália. O desenvolvimento de temáticas semelhantes que privilegiavam o interesse pelo "substrato patológico dos sentimentos, pelas degenerações e pelas monstruosidades, pelo amor sob o aspecto sexual, pelo homemanimal ou animalizado e pelas classes sociais que viviam na extrema pobreza da vida espiritual” levou Croce a considerá-los “irmãos na arte”. (CROCE, 1943: 103)

Mas, acima de tudo, o que assinala a diferença dos romances naturalistas e veristas em relação aos romances românticos é a construção narrativa: as coincidências, as revelações que ocorriam no momento oportuno ou o topos do reconhecimento, tão comuns nos romances do Romantismo, não mais estarão nessa nova arte proposta por Zola e Verga.

Segundo os críticos, era justamente essa negação da subjetividade romântica que impedia a criação artística no Naturalismo e no Verismo.

A questão da língua também era muito importante para os veristi. O dialeto assume um papel importante na narrativa, já que transmite a objetividade e o realismo almejados pelos autores. (FARRUGIA, 2005: 47) Ao contrário das outras obras de Serao, $O$ ventre de Nápoles é caracterizado por inúmeras inserções dialetais, sobretudo quando se refere a alimentos, profissões ou mesmo na reprodução de trechos de diálogos, como veremos mais adiante. Bianchi define esse dialeto como uma "linguagem de comunicação popular, distante do pitoresco e de reminiscências literárias”. (BIANCHI, 2008: 29)

Outro elemento importante na construção literária do Verismo é o discurso indireto livre, que garante a impessoalidade narrando a história a partir da perspectiva dos personagens. Não era um recurso novo, pois já havia sido utilizado por Jane Austen e também por Flaubert, em Madame Bovary, porém Zola e Verga utilizarão toda a sua 
potencialidade. (PELLINI, 2010: 66) Este recurso é usado por Serao em $O$ ventre de Nápoles sobretudo quando descreve os costumes, sentimentos e aspirações do povo napolitano, como nesta passagem em que trata sobre a grande comoção causada pelo jogo da loteria:

Nas portas, nos bassi, nas esquinas, os números são discutidos pelos grupos e subgrupos; o bilhete é decidido. Não sai: haviam se enganado, deviam jogar este ou aquele outro número, que saíram.

Além dos já citados Verga e Capuana na Sicília, o Verismo contava com representantes em outras regiões da Itália: Grazia Deledda, na Sardenha, Misasi na Calábria, Fucini, Pratesi e Lorenzini na Toscana, Cagna, Giacosi, De Marchi e De Amicis, no Piemonte. Farrugia destaca ainda que, como o Verismo possuía fortes "caracterizações regionais" e em pleno Ottocento as regiões conservavam ainda maiores diversidades, consequentemente os autores desenvolviam temas diferentes. (FARRUGIA, 2005: 47)

As peculiaridades de Serao e a comparação com outros autores da mesma tendência literária serão aprofundadas no próximo tópico.

\section{2 - Outros autores do Naturalismo e do Verismo: semelhanças e diferenças}

Uma das influências mais marcantes de Matilde Serao e que já se revela no próprio título do livro é sobretudo Émile Zola e sua obra $O$ ventre de Paris. Publicado em 1873, o romance gira em torno do personagem Florence que, após anos preso em Caiena por questões políticas, retorna a Paris e vai trabalhar como fiscal no Mercado da cidade. Nesse local, desenvolve-se boa parte da trama do romance e Zola dedica-se a minuciosas descrições do ambiente que se revela ao mesmo tempo exuberante com seus contrastes e nauseante com seus restos de alimentos em decomposição. Flores, frutas, legumes, carnes de aves e peixes formam o cenário do romance e relacionam-se às características físicas e psicológicas dos personagens. Uma clara referência a este aspecto é a seguinte passagem, na qual Serao descreve os mercados e vendedores ambulantes de Nápoles:

Aqui o romance experimental poderia até aplicar a sua tradicional sinfonia dos odores, já que somos submetidos a músicas inconcebíveis: o óleo frito, o salame estragado, o queijo forte, a pimenta amassada no pilão, o vinagre ácido, o bacalhau ensopado. 
Pellini afirma ainda que este destaque às sensações surgiu da própria concepção da ciência positivista, que passa a dar importância ao corpo e a suas reações. Na obra de Zola, o homem não é um ser puramente racional, mas alguém que vive sob influência de seus instintos. Paradoxalmente, o romance que confia ao olhar a tarefa de reproduzir fielmente a realidade acaba concedendo espaço a outros sentidos: "la vista, principe dei sensi, strumento della ragione, cede il passo alle percezioni confuse, e spesso inquietanti, dell'udito e dell'odorato" (PELLINI, 2010: 42).

Pellini enfatiza também que um fenômeno antropológico da época é responsável por essa nova abordagem literária: o surgimento da moderna metrópole, na qual "multiplicaram-se vertiginosamente as solicitações sensoriais, com seus sons ensurdecedores, seus odores inebriantes ou asquerosos, visões fantasmagóricas" (PELLINI, 2010: 42).

Ele destaca ainda que, entre os escritores italianos, Serao é quem mais se aproxima do modelo de Zola, sobretudo nas descrições exuberantes e na capacidade de captar os sons, odores e cores de uma grande cidade. (PELLINI, 2010: 43) De fato, a vivacidade e a minúcia das descrições de $O$ ventre de Nápoles tornam a obra quase visual, o que leva Farrugia (2005: 337) a compará-las às telas de Vincenzo Migliaro (1858-1938), artista napolitano pertencente à corrente verista da pintura e que se dedicava a retratar as contradições da cidade, dando destaque à paisagem e aos habitantes dos bairros mais miseráveis e abandonados. (Anexos 3, 4 e 5)

Entretanto, mesmo sendo admiradora da técnica do romance naturalista, pode-se observar que Serao deixa transparecer certa ironia quando descreve os mercados abertos de Nápoles, que considera sujos e incompatíveis com as noções de higiene e civilidade que predominam em uma cidade moderna, em sua afirmação: "de resto, tudo é belíssimo, para o pintor e para o romancista”.

A mesma crítica irônica pode ser percebida quando trata das crenças religiosas e das superstições populares e menciona as disputas dos habitantes dos becos para construir os mais belos oratórios e que acabavam culminando em violência: "essas pitorescas competições causam o êxtase dos artistas - essa raça de egoístas - que dedicam a vida à contemplação de seu Buda: a arte". Quando se refere aos mendigos que dormem sob o abrigo das colunas da igreja de São Francisco de Paula, uma das mais famosas de Nápoles, Serao é mais contundente: 
É também pitoresco para um romancista, circular nas ruas após a meia-noite: e encontrar homens que dormem sob o pórtico de são Francisco de Paula, com a cabeça apoiada nas bases das colunas: homens que dormem sobre os bancos dos jardins, na praça Município; meninos e meninas, que dormem nos degraus das igrejas de são Ferdinando, santa Brigida, Nossa Senhora das Graças, especialmente nesta última, que possui uma larga escadaria e alguns amplos terraços, no centro da rua Roma. (...)

Mas na realidade é muito, muito cruel que tudo isto ainda exista, e que seres humanos estejam submetidos a esta situação, e que homens de coração o suportem.

A metáfora do "ventre" também possui uma outra função: antes das reformas urbanísticas que as transformaram definitivamente, tanto Nápoles quanto Paris possuíam ruas estreitas e tortuosas, como tripas.

Croce porém afirma que o romance no qual fica mais evidente a influência de Zola é Il paese di Cuccagna:

In questo romanzo compie quasi una silloge artistica dei suoi molteplici studi sulle classi della società napoletana. Vi si trovano ripresi motivi già noti: l'usuraia popolana, la ragazza che si lascia sfruttare dall'amante, la vecchia aristocratica discesa nell'ambiente borghese, il lustrascarpe che vive pel lotto e che dichiara di non aver mai sentito bisogno di aver moglie perché egli ha, per compagnia e trattenimento, "la giocata'; e vi sono svolti parecchi aneddoti e figure, ch'erano stati con pochi tocchi accennati nel Ventre di Napoli. (...) La Serao ha voluto questa volta imitare la struttura del romanzo zoliano; e come in alcuni romanzi dello Zola l'acquavite, il danaro o il fornicare che si sottrae alla procreazione sono la forza nemica che trae a rovina una $o$ più classi sociali o l'intera società, e il romanzo offre una serie di esempi, tolti da vari strati ed ambienti, nei quali si segue il sicuro lavorio di quella forza malefica che opera come un fato. (CROCE, 1943: 52)

Além de Zola, Verga é outra influência importante na sua obra. A preocupação com a descrição da realidade e a incorporação de elementos da linguagem popular e até mesmo de termos dialetais aproximam, sem dúvida, o autor siciliano de Serao.

Entretanto, como narradora não adota uma postura de distanciamento. Demonstra empatia sobretudo por suas personagens femininas ao descrever suas vidas atribuladas, enfatizando os mais íntimos sentimentos tanto daquelas que pertenciam às classes mais abastadas quanto às classes populares, em uma época em que a sociedade ainda não permitia à mulher expressar livremente seu pensamento. (FARRUGIA, 2010: 359) Mesmo em $O$ ventre de Nápoles, dedica boa parte da obra para descrever o drama das mulheres de todas as profissões e condições: a mãe que não tem como alimentar o filho, a operária, a prostituta, a criada que se divide entre dois ou mais trabalhos.

Outro grande nome do Verismo é sem dúvida Luigi Capuana, que Croce considera o mais ardente defensor da "doutrina da impessoalidade" na Itália. Essa 
doutrina tem como base aquilo que o crítico considera um grave vício: a assimilação da arte às ciências naturais. Croce segue criticando a impessoalidade, que considera uma ilusão.

Capuana, descrito como mais dotado de "reflexão e cultura" do que Verga, iniciou sua carreira como crítico literário e seguidor das ideias de Francesco De Sanctis. (CROCE, 1943: 104) Como romancista e teórico do Verismo, defendeu a submissão da arte ao "método positivo das ciências naturais". Não por acaso, as curiosidades e as investigações científicas ocupam grande espaço em seus romances Giacinta e Profumo. (CROCE, 1943: 108)

Outro autor que, assim como Serao, tem como principal ponto de partida de sua obra os aspectos da vida napolitana é Salvatore Di Giacomo. Também foi jornalista, tendo colaborado com os jornais Corriere del Mattino, Pro Patria e Gazzetta, e foi fundador da revista de topografia e arte napolitana Napoli nobilíssima. Entretanto, diferente dela, que Croce define como uma "passional e exuberante escritora", Di Giacomo sente-se atraído pelos "espetáculos trágicos, humorísticos, macabros". (CROCE, 1943: 74)

Como afirma Farrugia, porém, o Verismo de Serao "é bastante peculiar, muito diferente daquele de Verga e Capuana, já que é uma alternância entre o distanciamento e a participação dos eventos narrados". Além disso, é um Verismo que começou em "pequenas doses", mantendo inicialmente algumas características românticas, para atingir a forma definitiva em $O$ ventre de Nápoles. (FARRUGIA, 2010: 411) Tampouco possui o tom trágico e fatalista das obras de Verga: embora seus personagens também sejam os "vencidos", Serao mostra que existe esperança e salvação para estas pessoas e não deixa de observar, com certa ironia, que a tradição, a religiosidade e a superstição podem ser um consolo para eles. (FARRUGIA, 2010: 414)

Apesar de tudo, em uma entrevista concedida ao jornalista Ugo Ojetti, Serao afirma que não se considerava uma escritora verista. Esta afirmação talvez esteja de certa forma relacionada a outra revelação feita pela autora na mesma ocasião: ela não se sentia à altura de outros escritores pelo fato de ser mulher. (FARRUGIA, 2010: 416)

Prese quindi a parlare più lentamente, perché l'emozione le aveva per un momento fatto gonfiare la gola. "Il romanzo - disse - il romanzo verista come lo intendo io, sì che l'avrei voluto scrivere, e lo avrei anche potuto; ma ...". Il volto della scrittrice si incupì 
improvvisamente e un'ombra passò su quel volto grasso, come se una tenda, sulla finestra che affacciava nella Galleria, si fosse abbassata.

"E' il romanzo della grande ingiustizia - disse - della suprema ingiustizia sociale, il romanzo della donna umiliata nel suo tragico crollo: il romanzo che nessuno ha scritto. Ed io l'avrei scritto. Ma ... mannaggia chesta ccà ...; tutta colpa di questa!". E la Signora prese il lembo della gonna e lo scosse con ira e dispetto. (GHIRELLI apud FARRUGIA, 2010: 18)

Para concluir, podemos citar duas afirmações que contribuem para esclarecer ainda mais as particularidades e a originalidade do Verismo de toda a obra de Serao:

Certo è un verismo diverso da quello degli altri veristi dell'epoca. Il suo è un verismo corale che promuove il fatto sociale dei bassi di Napoli all'altezza di arte, che si focalizza sulla figura femminile e la utilizza come oggetto di studio e di analisi come nessun altro autore contemporaneo seppe fare. (FARRUGIA, 2010: 420)

A segunda citação, de Tommaso Scappaticci, sustenta que o valor da obra seraoiana está não apenas no fato de que "oferece uma clara reprodução dos costumes e preconceitos da época, mas também mostra as mudanças culturais em um período iniciado com as esperanças alimentadas pela unificação e, em seguida, com o desenvolvimento do positivismo científico". (SCAPPATICCI apud FARRUGIA, 2010; 324). De fato, como podemos observar nas reproduções dos quadros a seguir, as descrições de Serao encontram eco nas obras dos pintores veristas ou impressionistas, bem como daqueles que compunham paisagens e desejavam eternizar a aparência de Nápoles antes do “desventramento.” (FARRUGIA, 2010: 421) Descrições minuciosas que fornecem ao leitor a sensação de realmente "ver a miséria napolitana, sentir o mau cheiro dos becos ou de tocar os farrapos dos mendigos". (FARRUGIA, 2010: 422) E nestas características estão as peculiaridades do verismo regional de Serao.

\section{3 - As características gerais da obra $O$ ventre de Nápoles}

Em $O$ ventre de Nápoles, ficam evidentes duas características fundamentais da literatura de Serao: o amor quase maternal à cidade de Nápoles e o estilo jornalístico. Christine Farrugia afirma que a autora "cria um retrato autêntico da cidade", transformando-a em um verdadeiro personagem, "um protagonista com vícios e virtudes”. Segundo Ghirelli, Serao captou de uma forma que só encontra comparação nas canções napolitanas as contradições dessa cidade, bela, mas vítima de invasões, terremotos e epidemias ao longo de sua história. (GHIRELLI apud FARRUGIA, 2010: 84). 
Como já foi destacado anteriormente, a obra possui uma estrutura peculiar. Está dividida em três partes: a primeira delas, chamada "Vinte anos atrás", é composta por nove artigos publicados originalmente no jornal Capitan Fracassa e recolhidos em uma edição de Fratelli Treves, de Milão, em 1884. Anos depois, foram acrescentadas a segunda e a terceira partes: "Agora" (1903) e "A alma de Nápoles” (1903-1905).

Quem melhor analisa e define as principais qualidades e defeitos da obra de Serao é Benedetto Croce: "ella è tutta osservazione realistica e sentimento; o meglio, osservazione mossa da sentimento" (CROCE, 1943: 34). Segundo o autor, essas características aparecem principalmente em $O$ Ventre de Nápoles, considerada por ele a melhor obra da autora. Croce destaca porém incorreções linguísticas e exagero no uso de termos dialetais como os principais pontos negativos do estilo de Serao:

Così calda, rapida, vivace è quest'arte della Serao. Sembra che il suo stile abbia assorbito l'eloquio abbondante, il gesticolare espressivo, i colori violenti, la commozione subitanea e irrefrenabile ch'è nella vita e nelle creature che essa ritrae. E, certamente, non tutti i suoi quadri sono di pari valore, e quà e là alcuni difetti li macchiano. Ma io non mi fermerò a notare qualche scorrezione di lingua, qualche imprecisione, qualche dialettismo non necessario; e neppure indugerò su quel che di scucito e di troppo cronachistico si nota in alcune novelle (...), o sulle tracce di frettolosità che si vedono in altre (...). Mi preme piuttosto mettere in chiaro, poiché ciò concorre a dare la fisionomia dell'arte della Serao, che, quando essa si allontana dalle cose viste o tenta toni troppo alti, le sue corde suonano falso. (CROCE, 1943: 48)

Em relação às questões linguísticas, Antonio Palermo também enfatiza o uso de "regionalismos lexicais, sintáticos e semânticos", bem como de "francesismos", que se deviam a suas "intensas leituras de Goncourt, Balzac, Flaubert e Zola”. Nesse sentido, desviava-se totalmente da tradição manzoniana. (PALERMO, 1990: 223)

Croce afirma preferir "os artigos de Il ventre di Napoli, incorretos e quase improvisados, mas espontâneos, do que o quadro sapiente de Il paese di Cuccagna". (CROCE, 1943: 54) Além de $O$ ventre de Nápoles, Croce elogia ainda suas últimas obras La ballerina e Suor Giovanna della Croce, nas quais "abandona o psicologismo e o misticismo e volta à vida vivida." (CROCE, 1943: 71) Esse caráter de improvisação e espontaneidade pode ser atribuído a sua produção literária considerada por Palermo "fluvial", pois se estendeu por praticamente meio século, em "um fluxo que não conheceu interrupções”. (PALERMO, 1990: 223)

Essa arguta capacidade de observação da realidade destacada por Croce é predominante nas duas primeiras partes de $O$ ventre de Nápoles. Já na terceira parte, A 
alma de Nápoles, ela volta-se para "a Fé, para o Desconhecido, para o Sobrenatural, para o Mistério". (CROCE, 1943: 70) Influenciados pelo cristianismo, os artigos finais caracterizam-se pela apresentação de exemplos de pessoas que haviam exercido a filantropia, como Teresa Ravaschieri, ou o assistencialismo à população, como fez o deputado Ettore Ciccotti. Croce analisa da seguinte forma essa tendência da autora:

Lo stesso giudizio poco favorevole è da stendere ai conati di letteratura mistica, che la Serao, contrariando la sua migliore ispirazione, ha voluto fare seguendo l'esempio di scrittori francesi e dell'italiano Fogazzaro, e non senza curiosi miscugli con reminiscenze di religione popolare o piccolo-borghese napoletana. (CROCE, 1943: 70)

Tais mudanças no estilo e na temática são compreensíveis, já que o período de tempo em que foram escritas as três partes da obra são muito grandes. Croce destaca ainda que a própria Serao justificava tal mudança afirmando que o naturalismo, com o "abuso da ciência" havia deixado de lado a fantasia. (CROCE, 1943: 70) Dessa fase, fazem parte também Le amanti, Gli amanti, Addio, amore, Castigo e Nel paese di Gesù, na qual narra as suas impressões de uma viagem à Palestina realizada em 1893.

Uma das características mais evidentes nas três partes de $O$ ventre de Nápoles é o uso recorrente de recursos da oralidade, dirigindo-se ao leitor sempre através do uso do pronome de tratamento voi. Já no artigo inicial, ela responde à celebre afirmação do Ministro do Interior Agostino Depretis de que seria "necessário desventrar Nápoles": “mas o senhor não conhecia, excelentíssimo Depretis, o ventre de Nápoles".

Nos artigos seguintes, Serao continua estabelecendo uma conversação com seu leitor, através de questionamentos, como no exemplo a seguir:

O senhor se surpreende com os oratórios? Espanta-se com a pequena procissão de mulheres descalças e descabeladas, que carregam uma imagem da Virgem e cantam salmos? A superstição do povo napolitano - oh, pobre gente que vive mal, mas com tanta bondade, que morre de um modo tão miserável e com tanta resignação! - a superstição desse povo causou uma dolorosa impressão em todos. Acreditava que houvesse cessado a superstição? Como pôde acreditar nisso? Então não se recorda de mais nada?

O uso constante de verbos no imperativo também é um recurso bastante utilizado pela autora para estabelecer contato e empatia com seu leitor:

Agora, faça as contas. Em cada beco há uma dona Carmela, em cada rua uma dona Raffaela, em cada praça uma agência autorizada; e em algumas ruas escuras, entre outros negócios, uma agência de penhor. Faça as contas, multiplique, pense na miséria, pense na loteria: de um lado a ganância e a astúcia: de outro a honestidade e a ingenuidade, a necessidade, a miséria. 
Além disso, Serao inclui vários relatos para comprovar seus argumentos e conferir maior dramaticidade. Na maioria das vezes, afirma que são casos que ela própria presenciou:

A criada napolitana recebe dez liras por mês, sem almoço: pela manhã caminha duas ou três milhas da sua casa à casa de seus patrões, sobe e desce as escadas quarenta vezes por dia, retira do poço vinte baldes de água, executa os trabalhos mais extenuantes, passa o dia sem comer e à noite arrasta-se para casa, exausta, como uma sombra. Existem também aquelas que assumem dois serviços ao mesmo tempo, por seis liras cada um, e correm de uma casa para outra, sendo continuamente advertidas pelas demoras. Conheci uma chamada Annarella, que se ocupava de três casas por dia, por cinco liras: à noite estava atordoada, não comia, morta de cansaço e às vezes nem se despia, para poder dormir logo.

Em uma passagem, ela chega a inserir um diálogo que chama de "Questionário" para exemplificar a má qualidade da alimentação dos cidadãos napolitanos:

\section{Questionário:}

Guisado de carne? - O povo napolitano não come nunca.

Carne assada? - Às vezes, aos domingos, ou nas grandes festas, mas é de porco ou de cordeiro.

Caldo de carne? - O povo napolitano o ignora.

Vinho? - Algumas vezes aos domingos: o asprino, por quatro soldos o litro, ou o maraniello a cinco soldos: este mancha a toalha de azul.

Água! - Sempre: e de má qualidade.

Inúmeros são os casos, desde os corriqueiros aos mais bizarros, que ela afirma ter visto ou ouvido falar: para demonstrar a solidariedade e a generosidade do povo napolitano, defendida incansavelmente em toda a obra, ela relata a história da mulher que deu à luz em pleno largo do Conselho e foi ajudada pelos populares. Em outra passagem, exemplifica a paixão pelos jogos de azar, falando sobre o homem que morreu de desgosto, pois durante anos havia apostado os mesmos números e, na única vez em que se esqueceu de jogar, estes foram sorteados.

Serao também não esconde suas impressões e seus sentimentos sobre as mais variadas situações que apresenta, o que se revela na profusão de adjetivos de alguns trechos:

E outra vez eu lhes direi o que vi, ali atrás, com uma triste e longa curiosidade, com uma coragem desesperada e, com a angústia mais opressora, do meu humilde porém fiel coração de napolitana! 
Os sentimentos de vergonha e de indignação também estão sempre presentes, recurso utilizado para acentuar o caráter de denúncia e atrair a atenção do leitor:

Como mulher, não posso dizer-lhe o que são essas ruas, pois nelas a abjeção torna-se tão profunda, tão miserável, a natureza humana se degrada a tal ponto, que sinto as faces queimarem de vergonha.

Bianchi afirma que essa observação é feita não apenas com os olhos, mas com os demais sentidos: o olfato para os odores muitas vezes nauseantes das comidas, o tato para a sujeira das ruas e o paladar para o sabor forte dos alimentos. Nota-se também o uso da memória nos trechos citados, pelos termos "lembro-me de" e "conheci uma". A própria Serao reconhecia que a memória era fundamental no seu trabalho de criação literária:

Io scavo nella mia memoria, nella memoria dove $\mathrm{i}$ ricordi sono disposti a strati successivi, come le tracce della vita geologica nella crosta terrestre, e vi do le note come le trovo, senza ricostruire degli animali fantastici... Dal primo giorno che ho scritto, io non ho mai voluto e saputo essere altro che una fedele e umile cronista della mia memoria. (FARRUGIA, 2005: 84)

Bianchi destaca também a recorrência do pronome eu nas três partes da obra, porém mais frequente nos textos de 1884. Dessa forma, Serao, pouco afeita à narração de experiências autobiográficas em seus contos e romances, acaba se tornando narradora, testemunha e praticamente protagonista de uma experiência da cidade (BIANCHI, 2008: 25).

Vemos, portanto, que $O$ ventre de Nápoles nada tem da arte impessoal que "não chora e não ri, que não deixa entrever simpatias ou antipatias, que não colore passional e sentimentalmente as próprias representações", que segundo Croce era o ideal do Verismo e nunca foi alcançado. (CROCE, 1943: 106)

Outro recurso utilizado, característico também em outros autores do Verismo, como Verga, é o discurso indireto livre, do qual extraímos um exemplo:

Um caso frequente de piedade é o seguinte: uma mãe muito fraca ou debilitada pelo trabalho dá à luz um bebê, mas não tem leite. Sempre tem uma amiga ou uma vizinha ou alguma desconhecida caridosa, que oferece o seu leite; amamentará dois, que importa?

Outra característica comum às três partes é o tom de denúncia. A falta de transparência nos gastos públicos, a reputação duvidosa dos governantes de Nápoles, o projeto urbanístico que privilegiava o embelezamento da cidade e deixava de lado as 
reais necessidades da parcela mais pobre da população são alguns dos alvos das denúncias recorrentes na maioria dos artigos. Nas duas primeiras partes, o tema central são as reformas que visavam a revitalização da cidade, já na terceira parte, diante da proximidade das eleições, Serao faz longas reflexões sobre a honra, que culmina no artigo intitulado "Guerra aos ladrões" em que afirma:

E, a propósito das não iminentes mas próximas eleições administrativas sabem o que diz Nápoles? Nápoles diz isto: A mim pouco importa que na Câmara Municipal haja clericais, borbônicos, moderados, liberais, democratas, socialistas ou anarquistas: tudo isto me é indiferente. Eu quero homens honestos: quero consciências seguras: quero almas austeras. As suas opiniões políticas não me interessam: apenas seus sentimentos morais me interessam. Não quero ladrões, no Comune; e ladrões não são apenas aqueles que levam meu dinheiro, o meu pobre e escasso dinheiro, mas todos aqueles que ajudam os ladrões ou que fecham os olhos e permitem que eu seja roubada.

Na terceira parte, além disso, o estilo descritivo inicial dá lugar a uma crônica mais emotiva, principalmente quando toma como exemplos as vidas de personalidades de Nápoles, como o político Ettore Ciccoti e a filantropa Teresa Ravaschieri. Aqui vemos a repetição, recurso típico da oralidade, aliada ao uso de muitos adjetivos para definir o caráter desses personagens:

Flutuam as belas recordações na minha mente e Teresa Ravaschieri me aparece como em uma selva de vívidas rosas perfumadas, e cada uma delas é um benefício, cada uma delas é uma caridade, cada uma delas é um ato de amor! Quantas vezes, no seu contato espiritual, senti revigorar-se minha enfraquecida fé cristã: já que ela era uma cristã perfeita, humilde, lúcida, terna sem afetação, esperançosa sem ousadia, confiante sem hesitação.

O mesmo tom emocional se revela quando descreve o exemplo dos trabalhadores em greve de Torre Annunziata:

Centenas de episódios comoventes que causam piedade poderiam ser narrados sobre eles sobre o modo como eles se ajudam mutuamente: e como os mais fortes dão força aos mais fracos: e como as mulheres são mais ardentes e mais firmes: e como nenhum fraqueja, nenhum trai nem ousa trair. São cinco mil, mas a vontade é apenas uma. Como uma barra de ferro que não se entorta, que não se move, e não se rompe.

Outro ponto que merece ser ressaltado é a presença das figuras femininas. Diferentes das personagens de seus romances, em sua maioria jovens burguesas ou damas aristocráticas, as mulheres de $O$ ventre de Nápoles são as operárias, as vendedoras de água sulfurosa de Santa Luzia, as criadas que se dividem entre vários trabalhos, as mães que sofrem para alimentar seus filhos ou as prostitutas. Quando se refere a estas últimas, Serao utiliza sempre termos como "as desventuradas e desgraçadas mulheres do povo que exercem a profissão mais atroz e digna de 
compaixão", "infelizes desocupadas" ou "mulheres desonradas". A única figura feminina de origem aristocrática está justamente no último artigo da obra, que homenageia Teresa Ravaschieri, dama da sociedade napolitana que dedicou sua vida à filantropia.

Ao descrever as vidas atribuladas dessas mulheres, Serao deixa clara sua posição no que diz respeito ao papel da mulher na sociedade: apesar de exercer funções que na época eram destinadas principalmente aos homens e de ter sido pioneira no jornalismo, acredita que a mulher deve dedicar-se ao lar e à criação dos filhos, e no máximo, a profissões "adequadas a mulheres", como professora, enfermeira ou escritora. Para ela, era inadmissível que a pobreza obrigasse as mulheres a trabalharem e a deixarem de lado o cuidado com os filhos. Em $O$ ventre de Nápoles, a única menção clara a esse fato está presente na seguinte passagem:

E como a miséria é constante, a mulher, a esposa, a mãe, ou seja, todas aquelas que pariram e amamentaram por diversas vezes e deveriam trabalhar em casa, procuram trabalho fora.

Christine Farrugia (2005: 135) fornece inúmeros exemplos da visão conservadora de Serao em relação à participação da mulher na política. Em 1887, publicou um artigo no Corriere di Roma intitulado "Votazione femminile", no qual se mostrava contrária à concessão de voto às mulheres e a qualquer participação feminina na política.Entretanto, é inegável que sua obra e sua carreira contribuíram para abrir caminho para outras mulheres tanto no jornalismo quanto na literatura.

Outra característica que merece ser destacada e que, com certeza, mais a aproxima do Verismo é o uso de termos científicos ("miasmas") ou nomes de substâncias ("ácido nítrico") bem como a constante comparação dos aspectos da cidade a partes do corpo humano, que já começa no próprio título, e se amplia no uso do léxico das doenças de degeneração do corpo: câncer, gangrena, putrefação, agonia e agonizar. (BIANCHI, 2008: 29)

Quando descreve os hábitos e superstições dos habitantes de Nápoles, deixa claro que sua concepção de modernidade e civilização estava alinhada com os princípios da ciência positivista. O hábito de jogar na loteria, comum em todas as camadas da população, mas visto pelos mais pobres como uma possibilidade de superar a miséria, é considerado por Serao “o verdadeiro câncer” do povo napolitano. 
Farrugia (2005: 19) destaca também que $O$ Ventre de Nápoles e Il paese di Cuccagna são as obras mais veristas da autora. De fato, na segunda obra são desenvolvidos temas que já haviam sido tratados na primeira, especialmente em relação ao jogo da loto. Entretanto, Il paese di Cuccagna foi o resultado de dois anos de intenso trabalho, e é repleto de descrições e detalhes, ao passo que a outra obra foi composta em forma de artigos jornalísticos diretos, sintéticos e objetivos.

Para concluir as reflexões sobre a obra, vale mencionar uma citação que Cristine Farrugia utiliza para definir a obra de Serao: "a literatura se transforma em vida, pois se concentra naquilo que é humano." (FARRUGIA, 2005: 169) E, sem dúvida, é em $O$ Ventre de Nápoles que esta frase encontra sua confirmação. 


\section{4 - Reflexões teóricas sobre a tradução de $O$ ventre de Nápoles}

A tradução de uma obra como $O$ ventre de Nápoles apresenta inúmeros desafios, primeiramente porque o seu objeto é demarcado por um período (passagem do século XIX para o século XX) e um local específicos (a cidade de Nápoles). Dessa forma, a incidência de termos culturalmente marcados é bastante grande e, diante disso, o tradutor tem, grosso modo, duas opções: a "domesticação", optando por uma tradução que privilegie o seu objetivo, ou seja, o texto de chegada, que vise aproximar o público leitor contemporâneo ao texto; ou o "estranhamento", uma tradução que mantenha as características do texto de partida.

O caminho escolhido pela tradução aqui apresentada tentou uma "conciliação" entre essas duas visões de tradução, partindo do princípio de que o tradutor não deve agir como o "moço de recados", mas como um "árbitro, buscando o entendimento, o acordo extrajudicial entre as partes" (AUBERT, 1993: 85), ou como afirma Umberto Eco, como o "negociador".

Isso, entretanto, não exclui o fato de que possam existir perdas durante $o$ processo, pois nem sempre a negociação é um acordo que distribui de forma igualitária vantagens e desvantagens entre as partes. (ECO, 2013: 94) Sobre isso trataremos mais adiante.

Quando tratamos da tradução de Il ventre di Napoli, é importante lembrar também, como afirma Umberto Eco "que o tradutor não deve apenas conhecer a língua mas também a história e a topografia de cada cidade". (ECO, 2013: 193) Nesse ponto, cabem algumas observações sobre a tradução de nomes de ruas, bairros ou regiões da cidade. Um caso em particular merece destaque: é muito comum, não apenas em Nápoles, mas também em outras cidades italianas, que certas ruas levem o nome dos profissionais que exerciam suas atividades no local, como fica exposto no trecho seguinte:

Da questa via partono tante altre viottole, che portano i nomi delle arti: la Zabatteria, i Coltellai, gli Spadari, i Taffettanari, i Materassari, e via di seguito. Sono, queste viottole - questa è la sola differenza - molto più strette dei Mercanti, ma egualmente sporche e oscure;

Dessa rua partem inúmeras outras ruelas, que levam os nomes das profissões:

Zabatteria, Coltellai, Spadari, Taffettanari, Materassari, e assim por diante. 
Essas ruelas são - e esta é a única diferença - muito mais estreitas do que a dos Mercanti, mas igualmente sujas e escuras;

Para esta questão, foi escolhida a manutenção dos nomes em italiano e a inserção de uma nota explicativa. Havia também a possibilidade da tradução dos nomes das ruas (sapateiros, mercadores etc.), entretanto, no caso de taffettanari e materassari, seria necessária a criação dos neologismos "tafetaneiros" e "colchoeiros". Em relação aos nomes de santos, optou-se por uma solução diferente. Todos os nomes foram traduzidos, com exceção do santo padroeiro San Gennaro, nome consagrado e que já faz parte do universo cultural da coletividade italiana e de seus descendentes em parte do Brasil.

As reflexões de Umberto Eco (2013: 198) sobre a hipotipose também ajudam a compreender melhor alguns elementos presentes no processo de tradução. A hipotipose é definida como o "efeito retórico pelo qual as palavras podem tornar evidentes fenômenos visivos". De um modo geral, Eco afirma que a hipotipose não oferece dificuldades para o tradutor, exceto no caso em que uma descrição verbal sugira uma imagem visual e exija uma experiência anterior. Em $O$ ventre de Nápoles, as descrições das ruas e das reformas pelas quais passaram são fundamentais para a compreensão e consequentemente para a tradução, já que a cidade é a protagonista da obra. Em algumas passagens, como na que será citada logo adiante, conhecer a cidade, caminhar pelos becos minuciosamente descritos pela autora e entender qual o impacto do “sventramento" promovido pelas reformas urbanísticas do final do século XIX revelouse essencial.

O segundo desafio diz respeito à definição do gênero textual da obra. Como já foi destacado na Introdução, $O$ ventre de Nápoles é uma obra híbrida, que inclui a observação sociológica, o ensaio de costumes e a investigação jornalística (MONTESANO, 2008: 13). Além disso, foi escrita em três épocas diversas, apresentando, por isso, variações estilísticas. Na primeira parte, escrita em 1884, concentra-se a maior incidência de termos culturalmente marcados, pois a autora dedica-se a descrever os hábitos da população napolitana, incluindo alimentação, moradia e religiosidade.

Vale também fazer algumas considerações a respeito da pontuação peculiar no processo de tradução. Em sua introdução à edição de 2008, Patricia Bianchi (2008: 31) 
destaca que o "uso inapropriado de pontuação" é constante em toda a obra de Serao. Entretanto, na presente tradução, optou-se pela manutenção dessa pontuação, da qual fornecemos um exemplo:

Nem o tempo que tudo modifica e tudo transforma: nem os homens enlouquecidos que deliram para mudar as coisas, de acordo com seu pensamento e capricho: nem os costumes que mudam bizarramente, mesmo que reapareçam em novas formas: nem os fatos regulados pelas misteriosas correntes do destino.

Podemos observar neste trecho o uso dos dois pontos por duas vezes consecutivas na mesma frase, desaconselhado pelos manuais de estilística atuais, mas bastante utilizado na prosa literária e em todo o decorrer da obra $O$ ventre de Nápoles. ${ }^{9}$ Temos também casos em que o sujeito foi separado do verbo: "O monge que adivinhou apenas um par, tem esperança de viver em paz" (...)

Encontramos não apenas as imprecisões relacionadas à pontuação, mas Bianchi menciona também formas ortográficas pouco usadas: "birrarie" (no lugar de "birrerie"), "adorazioni cucinarie" ("culinarie") ou "aiutatore del popolo". (BIANCHI, 2008: 31) Nas ocorrências citadas, não foram acrescentadas notas de rodapé às traduções.

Observam-se, além disso, períodos longos e repetições de palavras, como no trecho a seguir:

Il Rettifilo doveva salvare il popolo napoletano: e poichè gli occhi che guardano poco e fugacemente, poichè le labbra che domandano, non sempre sono esaudite da labbra che conoscano la verità, poichè il difetto di cui tutti siamo malati, è la fretta, poichè noi siamo, anche, malati di superficialità, poichè nessuno ha il tempo di fare quel che vorrebbe, nel mondo, poichè nessuno ha la volontà necessaria a eseguire tutto quello che vorrebbe, poichè tutto ci sfugge, per esser profondi, così, noi possiam credere che, veramente, il Rettifilo abbia dato al popolo napoletano tutto quello che gli mancava, e, sovra tutto, lo posson credere tutti coloro che passano qui un giorno o un mese!

A Avenida ${ }^{10}$ devia salvar o povo napolitano: e como os olhos que observam de forma fugaz, os lábios que perguntam, nem sempre recebem a resposta de lábios que conhecem a verdade, como o defeito do qual todos nós padecemos é a pressa, como também padecemos de superficialidade, como ninguém tem tempo de fazer aquilo de que gostaria, no mundo, como ninguém possui a vontade necessária para concretizar tudo o que gostaria, como tudo nos escapa, para sermos profundos, assim, conseguimos

\footnotetext{
${ }^{9}$ Elisa Tonani, "I due punti alcuni particolari usi". Accademia della Crusca, novembro 2009, acessado 30/07/2014. Neste artigo, a autora destaca que Carlo Emilio Gadda utilizava os dois pontos para garantir maior força expressiva em sua prosa.

${ }^{10}$ Refere-se ao Corso Umberto I.
} 
acreditar que, de fato, a Avenida tenha dado ao povo napolitano tudo o que lhe faltava, e, sobretudo, conseguem acreditar aqueles que passam aqui um dia ou um mês!

No decorrer da obra, podem ser encontrados inúmeros exemplos semelhantes e a alternativa seguida foi aquela apontada por Umberto Eco. Ao descrever sua experiência durante a tradução de $O$ Conde de Monte Cristo, de Alexandre Dumas, romance de cerca de mil páginas, Eco afirma que, embora em alguns momentos questionasse as passagens que julgava longas e redundantes e se seria necessário mantê-las em uma tradução feita nos dias de hoje, optou por mantê-las. (ECO, 2013: 123) Eco justifica sua opção afirmando que Dumas fazia longas descrições não apenas porque era pago por linhas, mas também porque era uma estratégia necessária para criar suspense e a sensação fundamental nesse romance de que a "vingança é um prato que se come frio". No caso de $O$ ventre de Nápoles, as repetições e os períodos longos foram mantidos, já que foram empregados pela autora para criar um efeito semelhante ao da oralidade e estabelecer um diálogo com seu leitor.

Além das reflexões apresentadas até aqui sobre as alternativas para determinadas questões, será feita a análise das modalidades de tradução tal como propostas por Aubert, em 1998, em sua reformulação do modelo de Vinay e Darbelnet. Para a análise apresentada a seguir selecionamos quarenta e seis termos culturalmente marcados da tradução da obra para o português.

O modelo de Vinay e Darbelnet foi inicialmente elaborado em 1958 e tem como objetivo preparar dados a partir da diferenciação linguística entre o texto de partida e o texto traduzido para fins de quantificação e estatísticas. Esse modelo consistia em um conjunto denominado "procedimentos técnicos de tradução", que incluía uma escala que partia do "grau zero" de proximidade com o texto de partida (empréstimo) até a adaptação, o procedimento considerado mais distante. Em 1980, este modelo foi revisto e assumiu um caráter descritivo e, dessa forma, o termo procedimento foi alterado para modalidade. (AUBERT, 1998: 103)

Um exemplo do uso da adaptação, ou seja, a substituição de um elemento cultural por outro próprio da cultura receptora, está na opção de tradução de altarini que, como a própria autora explica, são pequenos altares dedicados não apenas a santos, mas também a divindades pagãs, como as sibilas, que podem ser encontrados em diversos pontos da cidade de Nápoles ainda nos dias de hoje. Optou-se pelo uso de um termo bastante comum na cultura de chegada: oratórios, peças destinadas ao culto 
privado e público que se proliferaram pelo Brasil por influência dos colonizadores portugueses. Pode-se dizer também que neste caso ocorreu o que Eco considera a negociação de uma "vistosa violação de um abstrato princípio de literalidade". (ECO, 2013: 91)

Um processo semelhante ocorreu com o termo fondaco. No Vocabolario Treccani, as definições são múltiplas: palavra de origem árabe (funduq), designava um conjunto de edifícios onde os comerciantes estrangeiros depositavam as mercadorias e, em alguns casos, se alojavam. Em algumas regiões da Itália, ainda hoje o termo é usado para referir-se a um empório ou depósito de mercadorias ou a "certos locais destinados a habitações pobres". Esta última definição é a que mais se aproxima do significado encontrado em $O$ ventre de Nápoles, como é possível verificar na seguinte passagem:

un piccolo fondaco, una piccola Corte dei Miracoli, con le sue vanelle, e le sue botteghe brulicanti di ombre e le case brulicanti di poveri e d'infelici.

uma pequena vila, uma pequena Corte dos Milagres, com suas vielas, e seus estabelecimentos repletos de sombras e as casas repletas de pobres e infelizes.

Observa-se também uma grande incidência da transcrição, já que as vinte e uma ocorrências de termos no dialeto napolitano foram mantidas, com sua respectiva tradução em uma nota de rodapé. Um exemplo que merece especial atenção é o termo basso. No Vocabolario Treccani, encontramos a seguinte definição de basso: "A Napoli, negli edifici, vano aperto a livello della strada, per abitazione di povera gente (nel dialetto napol., vàscio)." "11 Podemos ver também a descrição dada por Serao:

E, difatti, nessuna compassione e nessun ribrezzo più grande che il cacciar il viso a fondo in questi bassi ove vive e mal vive il popolo, in questi bassi che sono già oscuri, oppressi, angusti nelle vie più grandi e che nei vicoli, in cento vicoli, in mille vicoli diventano delle stamberghe sotterranee, quasi diventano degli antri ove si agitano e brulicano le vite umane, piccole, grandi, decrepite. Il basso è una bottega rudimentale, un terraneo, piuttosto, senza finestra, senza cesso, senz'altro sfogo che una porta, talvolta angusta che, d'inverno, deve star chiusa, che, di notte, non può stare aperta;

De fato, nada desperta maior compaixão e maior repugnância do que mergulhar nestes bassi onde vive o povo mal, nestes bassi que já são escuros, oprimidos, estreitos tanto nas ruas maiores quanto nos becos, em cem becos, em mil becos tornam-se refúgios subterrâneos, tornam-se antros onde pululam e se agitam as vidas humanas, pequenas, grandes, decrépitas. O basso é um estabelecimento rudimentar, térreo, quase, sem janela, sem privada, com apenas uma porta de saída, tão estreita que, no inverno, deve estar fechada, que, à noite, não pode estar aberta;

\footnotetext{
${ }^{11}$ Para maiores informações ver Anexo 3.
} 
Em relação a isso, seguimos a reflexão de Umberto Eco sobre o diálogo em francês que abre Guerra e Paz de Tolstoi. Segundo ele, a intenção do autor era fazer seus leitores entenderem que os aristocratas russos da época napoleônica usavam o francês, pois representava cultura e refinamento apesar de ser a língua do inimigo. (ECO, 2013: 169) Eco destaca que nas traduções dessa obra o estranhamento causado pelo diálogo em francês deve ser mantido, dando como exemplo uma possível tradução para o chinês. Nesse caso, uma alternativa seria a tradução para o inglês, porém seria perdida a referência a um momento histórico preciso (os russos estavam em guerra contra os franceses). Em $O$ ventre de Nápoles, a opção de Serao pelo dialeto napolitano revela seu desejo de colocar-se ao lado da população desfavorecida da cidade. Por esse motivo, na tradução para o português, as ocorrências em dialeto foram mantidas, com a devida explicação na nota de rodapé. Em outros casos, que serão mostrados a seguir, a nota revelou-se desnecessária, pois a própria autora encarregou-se da explicação:

- tarallaro, o popular vendedor de biscoitos

- As cabeleireiras do povo, as chamadas capere, que ganham um soldo por dia,

- A iguaria mais apreciada é o soffritto: preparado com pedaços de carne de porco cozida com óleo, tomate e pimentão vermelho, formando uma pasta densa e vermelha,

Obviamente, como destaca Eco, a perda em alguns momentos é inevitável (ECO, 2013: 94). Como exemplo, podemos citar a descrição feita por Serao sobre a usurária D. Carmela:

Donna Carmela è una donna grassa e grossa che esercita per lo più una professione di lusso, rammenda merletti, trapuntisce le grandi coltri di bambagia che si usano in Napoli (...)

Donna Carmela é uma mulher grande e gorda que exerce na maior parte do tempo uma profissão de prestígio, remenda as rendas, borda os grandes mantos de lã que se usam em Nápoles (...)

$\mathrm{Na}$ tradução, perdeu-se o jogo de palavras que resultava na aliteração "grassa e grossa".

O único exemplo de decalque encontrado foi o termo napolitanismo, como se pode verificar no trecho a seguir:

Ivi è il Lavinaio, la grande fonte, dove si lavano i cenci luridi della vecchia e povera 
Napoli: il Lavinaio, che è il grande ruscello, dove il luridume viene a detergersi superficialmente; tanto che per insultare bonariamente un napoletano, sul proprio napoletanismo, gli si dice. - Sei proprio del Lavinaio.

Nesse ponto localiza-se o Lavinaio, a grande fonte, onde se lavam os trapos imundos da velha e pobre Nápoles: o Lavinaio, um grande riacho, onde a imundície se dissolve superficialmente; tanto que para insultar amigavelmente um napolitano, sobre seu próprio napolitanismo, costuma-se dizer. - Você é mesmo do Lavinaio.

Também é importante acrescentar algumas reflexões sobre a tradução literal em todo o decorrer desta dissertação. Como já foi destacado na Introdução, o que norteou este trabalho foi principalmente o conceito de negociação proposto por Umberto Eco. Houve a preocupação em tornar o texto acessível ao leitor brasileiro contemporâneo, mas sem apagar as características da obra e de seu tempo. Portanto, em alguns casos a melhor alternativa revelou-se a tradução literal, em outros, porém, foram necessárias alterações sintáticas para que o segmento se tornasse compreensível para o português brasileiro:

Nessuna donna che mangi, nella strada, vede fermarsi un bambino a guardare, senza dargli subito di quello che mangia: e quando non ha altro, gli dà del pane.

Na rua, não há mulher que, ao perceber que uma criança a olha, não lhe dê imediatamente o que estiver comendo: e quando não tiver outra coisa, lhe dá o pão.

Para finalizar, apresento a tabela com os resultados finais da análise das modalidades:

\begin{tabular}{|l|l|l|}
\hline Modalidades & $\mathbf{n}^{\mathbf{0}}$ & \% \\
\hline Omissão & 0 & 0 \\
\hline Transcrição & 32 & 69,5 \\
\hline Empréstimo & 0 & 0 \\
\hline Decalque & 1 & 2,1 \\
\hline Tradução literal & 4 & 8,6 \\
\hline Transposição & 2 & 4,3 \\
\hline Explicitação & 0 & 0 \\
\hline Modulação & 0 & 0 \\
\hline
\end{tabular}




\begin{tabular}{|l|l|l|}
\hline Adaptação & 7 & 15,2 \\
\hline Erro & 0 & 0 \\
\hline Total & 46 & 100 \\
\hline
\end{tabular}

Vemos que a modalidade mais utilizada foi a transcrição, seguida da adaptação. Não é possível, no entanto, considerar o resultado deste levantamento como uma regra para todas as traduções com grande incidência de termos culturalmente marcados. Afinal de contas, assim como toda obra literária, toda tradução é única. 


\section{Conclusão}

Embora se mostrasse conservadora em relação ao papel da mulher na sociedade e na política, Matilde Serao exerceu um papel muito importante na emancipação feminina, pois foi a primeira mulher na Itália a fundar e dirigir um jornal. Além disso, se considerarmos que, diferente da literatura em língua inglesa, na qual temos nomes como Jane Austen, na literatura italiana as escritoras foram em menor número, Matilde Serao, bem como Deledda, Neera e Sibilla Aleramo exerceram um papel muito importante abrindo caminho para outras autoras que se destacariam posteriormente, como Natalia Ginzburg, Elsa Morante, Dacia Maraini e Susanna Tamaro.

Matilde Serao é verista, porém seu Verismo apresenta características originais que a distinguem dos dois grandes autores veristas italianos: Giovanni Verga e Luigi Capuana. $O$ ventre de Nápoles, sua obra considerada verista por excelência pelos críticos, dá grande destaque às figuras femininas e coloca-se como uma narradora não apenas observadora, mas participante.

Embora mais de um século tenha se passado, os escritos de Serao revelam-se mais atuais do que nunca. A presente tradução, além de contribuir para a divulgação da obra da autora no Brasil, acende o debate sobre o espaço urbano e serve para refletir sobre o modo como estão organizadas nossas cidades e que um projeto urbanístico vai e deve ir muito além de um embelezamento superficial.

A questão da criminalidade organizada e do descaso do poder público, já denunciados por Serao no final do Ottocento, também estão presentes nas obras atuais de Roberto Saviano. O jornalista napolitano, que em 2006 ganhou notoriedade ao lançar o livro Gomorra, apresenta em detalhes todo o sistema que sustenta a Camorra, a máfia napolitana. Em virtude disso, o escritor recebeu ameaças dos chefes do crime organizado e vive desde então sob escolta policial. Embora tenha um estilo jornalístico muito semelhante ao de Serao, Saviano vai adiante e estuda as relações do crime organizado no mundo, afirmando que o Sul da Itália paga o preço com mortes e violência, quando na verdade o Norte também está envolvido.

De qualquer forma, a imagem que prevalece é a de uma cidade fascinante, contraditória, multifacetada. De fato, como Serao escreve na abertura de sua obra e Pino 
Daniele em sua canção, Nápoles é uma cidade que "todos conhecem, mas não sabem a verdade":

Napule è tutto nu' suonno e a sape tutto 'o m unno

Ma nun sann' a verità 


\section{O ventre de Nápoles}

(Vinte anos atrás - Agora - A alma de Nápoles)

Matilde Serao 


\section{À baronesa Júlia de Rothschild}

Pavillon de Pregny - Genebra

Minha amiga,

A senhora que amou e ainda ama Nápoles, com o coração ardente, a mente elevada e esclarecida: ao desejar o bem a esta admirável cidade, demonstra com veemência toda a bondade presente em seu espírito.

Apenas à senhora, portanto, desejo dedicar este livro de ternura, piedade e tristeza - por

Nápoles.

E espero também que continue dedicando apreço a esta sua amiga.

Matilde Serao. 
Este livro foi escrito em três épocas diversas.

A primeira parte, em 1884, quando em uma cidade distante, a mim chegava de Nápoles todo o sentido de horror, de terror, de piedade, pelo flagelo que a atravessava, semeando a doença e a morte: e que a dor, a ânsia, a aflição que dominam, em quem escreve, qualquer cuidado, de arte, digam quanto sofreu profundamente, então, o meu coração de napolitana.

A segunda parte, foi escrita vinte anos depois, ou seja apenas dois anos atrás, e se relaciona à primeira, com um sentimento mais tranquilo, mas, oh céus, mais desconfiado, mais cético que um melhor futuro social e civil, possa algum dia ser assegurado ao povo napolitano, do qual quem escreve se orgulha e se vangloria de ser fraterna emanação.

A terceira parte é de ontem, é de hoje: nem preciso esclarecê-la, pois é como as outras: expressão de um coração sincero, de uma alma sincera: expressão terna e dolorida: expressão nostálgica e triste de um ideal de justiça e de piedade, que desça sobre o povo napolitano e o eleve ou o exalte!

NAPOLI, outono de 1905

\section{Matilde Serao}




\section{Vinte anos atrás}

\section{É PRECISO DESVENTRAR NÁPOLES}

A frase é correta, mas o senhor não conhecia, excelentíssimo Depretis ${ }^{12}$, o ventre de Nápoles. Isto é um erro, pois o senhor é o Governo e o Governo tudo deve saber. Não são feitas para o Governo, certamente, as reles descrições coloridas dos cronistas com intenções literárias, que falam da rua Caracciolo, do mar verde claro, do céu azul cobalto, das senhoras encantadoras e dos tons violáceos do por do sol: toda essa retórica que descreve o golfo e as colinas floridas, da qual já nos arrependemos e continuamos a nos arrepender, humildemente ajoelhados diante da pátria que sofre; toda essa diminuta e fácil literatura fragmentária é útil para aquela parcela do público que não deseja ser incomodada com relatos de misérias. Mas o governo devia conhecer a outra parte; o governo ao qual chega a estatística da mortalidade e dos crimes; o governo ao qual chegam os relatórios dos prefeitos, dos delegados de polícia, dos inspetores, dos representantes; o governo ao qual chegam os relatórios dos diretores dos presídios; o governo que sabe tudo: quanta carne se consome em um dia e quanto vinho se bebe em um ano, em uma cidade; quantas mulheres desonradas, digamos assim, existem, e quantos de seus amantes foram advertidos, quantos mendigos não podem entrar nas obras de caridade e quantos vagabundos dormem na rua à noite; quantos proletários e quantos comerciantes existem; quanto rende o imposto sobre o consumo ${ }^{13}$, ou o imposto fundiário, ou quanto é penhorado no Monte di Pietà ${ }^{14}$ e quanto rende a loteria. Essa outra parte, este ventre de Nápoles, se o Governo não o conhece, quem deve conhecêlo? E se não servem para informar sobre tudo, para que servem esses bons funcionários, de alto e baixo escalão, para que serve essa imensa engrenagem burocrática que nos custa tanto? E, se o senhor não é a inteligência suprema do país, que tudo sabe e tudo resolve, por que é ministro?

$$
\begin{aligned}
& * \\
& * *
\end{aligned}
$$

\footnotetext{
12 Agostino Depretis (1813-1887) foi por nove vezes presidente do Conselho de Ministros do Reino da Itália. Na época em que Serao escreveu $O$ Ventre de Nápoles, Depretis era Ministro do Interior. O ensaio foi escrito como resposta a sua declaração de que era necessário "sventrare Napoli" para acabar com a epidemia de cólera.

${ }^{13}$ Dazio consumo: imposto instituído sobre o consumo de alimentos e bebidas em 1864 no Reino da Itália.

${ }^{14}$ Instituição financeira, sem fins lucrativos, também conhecida como Banco dos Penhores. Surgiu na Itália no século XV por iniciativa dos Franciscanos.
} 
Devem ter-lhe mostrado uma, duas ou três ruas dos bairros da parte baixa que lhe causaram horror. Mas o senhor não viu tudo; os próprios napolitanos que o conduziram não conhecem todos os bairros da parte baixa. A rua dos Mercanti, o senhor a percorreu inteira?

Deve ter cerca de quatro metros de largura, tanto que as carroças não conseguem passar, além de ser sinuosa e retorcida como uma tripa: as altíssimas casas a deixam imersa, durante os dias mais ensolarados, em uma luz baça e morta: no meio da rua há um córrego negro, fétido, que não se move, estagnado, feito de água sanitária, espuma de detergente suja, água de macarrão e água de sopa, uma mistura mal cheirosa que apodrece. Nessa rua dos Mercanti, uma das principais do bairro do Porto, encontra-se de tudo: lojas escuras, repletas de sombras, que vendem todo tipo de mercadoria, agências de penhor, casas de loteria; e a cada passo um portãozinho negro, um beco lamacento, um vendedor de frituras, de onde se espalha o fedor do óleo de má qualidade, um vendedor de frios, onde se sente o cheiro de queijo azedo e de toucinho estragado.

Dessa rua partem inúmeras outras ruelas, que levam os nomes das profissões: Zabatteria $^{15}$, Coltellai ${ }^{16}$, Spadari $^{17}$, Taffettanari ${ }^{18}$, Materassari ${ }^{19}$, e assim por diante. Essas ruelas são - e esta é a única diferença - muito mais estreitas do que a dos Mercanti, mas igualmente sujas e escuras; e cada uma delas possui um odor diverso: de couro velho, de chumbo derretido, de ácido nítrico, de ácido sulfúrico.

Várias ruas que vêm da parte alta da cidade levam ao bairro do Porto: são inclinadas, estreitas, com calçamento irregular. A rua de Mezzocannone está repleta de tintureiros: nos fundos de cada estabelecimento, arde na escuridão um fogo vivo sob um enorme caldeirão negro, onde os homens seminus mexem uma mistura fumegante; sobre a porta panos vermelhos e roxos são colocados para secar; sobre o calçamento irregular, escorre sempre uma escória de tintura multicolorida. Outra rua, conhecida como Degraus di Santa Barbara, também tem sua particularidade: dominada por mulheres desonradas que, por ócio de infelizes desocupadas, durante o dia, e por ódio profundo contra os homens, atiram da janela, sobre quem passa, cascas de figos, de melancia, lixo, talos de espigas, e tudo fica sobre estes degraus, de modo que as pessoas limpas não ousam mais passar por ali. Existe outra rua, que por trás do educandário de

\footnotetext{
15 Sapatarias.

${ }^{16}$ Fabricantes de facas, tesouras e similares.

${ }^{17}$ Fabricantes de espadas

${ }^{18}$ Fabricante e comerciantes de tafetá

${ }^{19}$ Fabricantes de colchões e travesseiros
} 
São Marcelino, conduz a Portanova, onde termina a rua dos Mercanti e começa a dos Lanzieri: não é uma rua de fato, é um beco, uma espécie de canal negro, que passa sob dois arcos e onde parece ter sido acumulado todo o lixo de um povoado africano. A um certo ponto, não é possível prosseguir: o chão é imundo e o estômago se contrai.

$$
\begin{gathered}
* \\
* *
\end{gathered}
$$

Em Vicaria ${ }^{20}$, o senhor já esteve?

Entre todas as ruas que cruzam o bairro, apenas uma é limpa, a rua do Duomo: as outras são representações da velha Nápoles: apertadas, escuras, com casas tão antigas que correm risco de desabamento mesmo com os reforços. Lá se encontra o beco do Sol, assim chamado porque a luz do sol não entra nunca; o beco do Sétimo Céu, que deve seu nome a uma pequena faixa de céu que aparece entre as altas e antiquíssimas casas. Em torno da praça SS. Apostoli, há três ou quatro ruelas: Grotta della Marra, Santa Maria a Vertecœli e beco da Campana, onde vivem pessoas magras e pálidas contaminadas pela própria sujeira e pela fábrica de tabaco ali existente. Os arredores de Castelcapuano $^{21}$, bem como de todo o bairro de Vicaria, parecem ser o seu próprio ambiente, ou seja, a podridão material e moral, de onde se avista o destino desta sociedade pobre e necessariamente corrompida: a prisão.

O bairro Mercato? Ah, sim, o bairro histórico onde Masaniello ${ }^{22}$ fez a revolução, onde decapitaram Conrado da $\mathrm{Suábia}^{23}$; obviamente, pois disso falaram os dramaturgos e poetas. Saindo da Ferrovia em carruagem e indo em direção à Marina cruza-se apenas um trecho. Para o diabo com a poesia e o drama! No bairro Mercato, nenhuma rua é limpa; parece que há anos não passa um varredor; e talvez toda essa sujeira tenha sido acumulada em apenas um dia.

Nesse ponto localiza-se o Lavinaio, a grande fonte, onde se lavam os trapos imundos da velha e pobre Nápoles: o Lavinaio, um grande riacho, onde a imundície se

20 É um dos bairros que fazem parte da subdivisão histórica da cidade, que remonta à época grecorromana. Os outros são: San Ferdinando, San Giuseppe, San Lorenzo, Porto, Pendino, Chiaia, Montecalvario, Avvocata, Stella, San Carlo all'Arena e Mercato.

${ }^{21} \mathrm{Um}$ dos castelos mais antigos de Nápoles, remontando à época normanda. Inicialmente, serviu de residência real e posteriormente foi transformado em Tribunal.

${ }^{22}$ Um dos líderes da revolta ocorrida em Nápoles, em 1647, contra a dominação espanhola.

${ }^{23}$ Conrado da Suábia (Wolfstein, 1252- Nápoles, 1268) foi duque da Suábia, rei da Sicília e rei de Jerusalém. Último da Dinastia Hohenstaufen, foi decapitado em Nápoles, na atual Piazza del Mercato. 
dissolve superficialmente; tanto que para insultar amigavelmente um napolitano, sobre seu próprio napolitanismo, costuma-se dizer. - Você é mesmo do Lavinaio. No bairro Mercato, encontram-se os sete becos da Duchesca, em um dos quais, pelo que li em um despacho, ocorreram trinta casos em uma hora; há os becos do Cavalcatoio e de Sant'Arcangelo a Baiano. Como mulher, não posso dizer-lhe o que são essas ruas, pois nelas a abjeção torna-se tão profunda, tão miserável, a natureza humana se degrada a tal ponto, que sinto as faces queimarem de vergonha.

$$
\text { * }
$$

Desventrar Nápoles? Acredita que será suficiente? Espera que bastará a abertura de três ou quatro ruas nos bairros populares para salvá-los? Verá, quando os estudos para esta santa obra de redenção estiverem concluídos, uma verdade resplandecente surgirá: é necessário reconstruí-la.

Certamente não será possível manter em pé as casas afetadas pela umidade, onde no térreo se encontra um lamaçal e no último andar morre-se de calor no verão e de frio no inverno; onde as escadas estão cobertas pelo lixo; em cujos poços, onde se consegue água a duras penas, caem todos os dejetos humanos e os animais mortos; e que, além disso, possuem um pot-bouille ${ }^{24}$, una espécie de viela ${ }^{25}$, um pátio interno onde as criadas atiram de tudo; e o sistema de latrinas, quando existe, é impossível de ser desinfetado.

Certamente não será possível manter em pé as casas, onde se aglomeram em pequenos quartos ao menos quatro pessoas, além de galinhas, pombos, gatos esfomeados e cães sarnentos; onde as pessoas cozinham em cubículos, comem no quarto e morrem no mesmo cômodo em que os outros dormem e comem; os porões, embora habitados por seres humanos, assemelham-se ao antigo, e atualmente desativado, cárcere subterrâneo da Vicaria.

Certamente não será possível manter em pé as passarelas que ligam os edifícios; nem aquelas ignóbeis construções de madeira que permanecem suspensas junto às casas, nem aqueles portõezinhos estreitos, nem as ruas sem saída, nem os

\footnotetext{
${ }^{24}$ Título de um romance de Émile Zola, que conta a história de várias famílias pobres que vivem em um edifício parisiense. Literalmente significa "panela que ferve".

${ }^{25}$ No texto em italiano, vinella, proveniente do termo em francês venelle.
} 
becos, nem os pórticos; não será possível manter em pé os galpões.

Certamente não será possível manter em pé certas casas onde no primeiro andar funciona uma casa de penhores, no segundo alugam-se quartos para estudantes, no terceiro fabricam-se fogos de artifícios: outras onde o térreo é um bilhar, o primeiro andar um hotel onde se paga três liras por noite, o segundo um abrigo de pobres mulheres e o terceiro um depósito de trapos.

Para combater a corrupção material e moral, para recuperar a saúde e a consciência dessas pobres pessoas, para ensinar-lhes como se vive - pois morrer eles sabem, como o senhor viu! - para dizer-lhes que eles também são nossos irmãos, que nós os amamos incondicionalmente, que desejamos salvá-los, não basta desventrar Nápoles: é necessário reconstruí-la quase por completo.

\section{II}

\section{O QUE ELES GANHAM}

Apesar de tudo, as pessoas que moram nesses quatro bairros populares, sem ar puro, sem luz, sem higiene, chafurdando nos córregos negros, despejando montes de lixo, respirando miasmas e bebendo água contaminada, não são bestiais, selvagens, ociosas; não são melancólicas na fé, nem mergulhadas no vício ou coléricas na desventura. Este povo, por sua natural nobreza de sentimentos, ama as casas brancas e as colinas: por isso no dia de Todos os Santos, quando as pessoas de bem de Nápoles levam coroas de flores aos mortos, na colina de Poggioreale, naquele cemitério repleto de flores, pássaros, perfumes e esculturas de mármore, é comum ouvir quem exclame: $o$ Gesù, vurria murì, pe sta ccà! ${ }^{26}$ Este povo ama as cores alegres, por isso adorna com guirlandas e pingentes os cavalos das carroças, enfeita-se com peninhas multicoloridas nos dias de festa, amarra lenços escarlates no pescoço, coloca um tomate sobre um saco de farinha, para obter um efeito pitoresco e criou um monumento de metal brilhante, madeira pintada, limões perfumados, copos e garrafas, um pequeno monumento que é uma festa para os olhos: a banca do vendedor de água.

Este povo que ama e faz a música, que canta suas canções de um modo amoroso e melancólico, provocando um aperto no coração e uma profunda saudade em quem está distante, possui uma sentimentalidade expansiva, que se difunde na harmonia musical. Não é, portanto, uma raça de animais, que se compraz na lama; não é uma raça inferior

\footnotetext{
${ }^{26}$ Em dialeto napolitano: Oh, Jesus, como gostaria de morrer para ficar aqui!
} 
que escolhe a baixeza e procura voluntariamente a imundície; não merece a sorte à qual foi submetido; saberia apreciar a civilização, visto que as poucas benfeitorias foram por eles rapidamente assimiladas; merece ser feliz.

Por necessidade, mora na parte baixa da cidade.

Sua miséria é tão constitucional, orgânica, intensa e profunda, que cem Obras de Caridade não seriam capazes de solucionar, que a filantropia, tão frequente, não conseguiria vencer; e, veja bem, não é a miséria do ocioso, é a miséria de quem trabalha quatorze horas por dia.

Esse trabalhador, esse operário não pode pagar mais do que quinze liras por mês pelo aluguel de uma casa: e deve ser um operário de sorte, há quem pague dez, sete ou cinco; estes últimos representam a maioria do povo. Há alguns anos, uma cooperativa construiu próximo a Capodimonte, um conjunto de casas operárias claras, limpas e pequenas, mas pelo menos higiênicas: por mais que tentassem abaixar os preços, não conseguiram vender seus pequenos apartamentos por menos de trinta e quatro liras por mês.

Nenhum operário foi morar lá.

Acabou sendo ocupada por funcionários com suas famílias, alguns aposentados, jovens casais pobres, enfim, uma média burguesia que deseja esconder a sua miséria e ter uma escadinha de mármore.

Aquele enorme edifício permanece ali para comprovar a miséria napolitana: aliás, os escrupulosos e burgueses que nele moram, ofendidos por aqueles que os acusavam de morar nas casas operárias, mandaram pintar em letras garrafais esta frase na entrada principal:

as casas da Cooperativa não são casas operárias. Frase cruel e soberba.

Trinta e quatro liras? Estas trinta e quatro liras um trabalhador napolitano ganha em um mês: quem leva uma lira para casa após uma jornada pode considerar-se feliz.

As remunerações são baixíssimas, em quase todas as profissões, em todos os ofícios. Nápoles é a cidade onde a obra tipográfica custa menos; todos sabem: os operários tipógrafos recebem um terço a menos do que recebem em outras cidades. Em Milão recebem cinco liras, em Roma quatro, e duas em Nápoles, tanto que é nesta abençoada e infeliz cidade onde mais facilmente nascem e vivem certos jornaizinhos paupérrimos, que em outros lugares não conseguiriam publicar nem mesmo três 
números. Os alfaiates, os sapateiros, os pedreiros e os carpinteiros são pagos da mesma forma; una lira, vinte e cinco soldos, no máximo, trinta soldos por dia por doze horas de trabalho, às vezes penosíssimo. Os fabricantes de luvas ganham noventa centavos por dia. Observe que a juventude elegante de Nápoles é a mais bem vestida da Itália: em Nápoles se fazem os mais belos sapatos, os mais belos móveis econômicos e as melhores luvas. Outros ofícios inferiores estabelecem a remuneração a setenta e cinco centavos, a doze soldos, a dez soldos. Por isso eles não podem pagar mais de cinco, sete ou dez liras por mês de aluguel. E como a miséria é constante, a mulher, a esposa, a mãe, ou seja, todas aquelas que pariram e amamentaram por diversas vezes e deveriam trabalhar em casa, procuram trabalho fora.

Felizes daquelas que encontram trabalho na Fábrica de tabaco, que sabem trabalhar e conseguem empregar-se como costureiras, modistas ou floristas! A remuneração é miserável, quinze, dezessete ou vinte liras por mês; mesmo assim podem ser consideradas sortudas. Mas é a minoria: todo o resto da imensa classe pobre feminina dedica-se aos trabalhos domésticos.

A criada napolitana recebe dez liras por mês, sem almoço: pela manhã caminha duas ou três milhas da sua casa à casa de seus patrões, sobe e desce as escadas quarenta vezes por dia, retira do poço vinte baldes de água, executa os trabalhos mais extenuantes, passa o dia sem comer e à noite arrasta-se para casa, exausta, como uma sombra. Existem também aquelas que assumem dois serviços ao mesmo tempo, por seis liras cada um, e correm de uma casa para outra, sendo continuamente advertidas pelas demoras. Conheci uma chamada Annarella, que se ocupava de três casas por dia, por cinco liras: à noite estava atordoada, não comia, morta de cansaço e às vezes nem se despia, para poder dormir logo.

Estas criadas ainda encontram tempo para amamentar um bebê, de costurar meias, mas são seres monstruosos, a piedade que inspiram é proporcional à repugnância. Têm trinta anos mas demonstram cinquenta, são curvadas, perderam os cabelos, os seus dentes são amarelados e enegrecidos, caminham como se fossem defeituosas, usam o mesmo vestido por quatro anos e um avental por seis meses.

Não se lamentam nem choram: vão morrer, com menos de quarenta anos, no hospital, de febre perniciosa, de pneumonia ou de qualquer terrível doença. E quantas foram levadas pelo cólera! 
E as outras profissões ambulantes femininas, lavadeiras, cabeleireiras, passadeiras diaristas, vendedoras de spassatiempo $^{27}$, empalhadoras de cadeiras (mpagliaseggie), que as expõem a todas as intempéries, a todos os acidentes, a inúmeras doenças, ofícios pesados ou insalubres, que não rendem a essas pobres infelizes mais de dez soldos, quinze soldos por dia. Quando ganham uma lira, as miseráveis economizam e se casam.

São feias, é verdade, também descuidadas: causam nojo, às vezes. Mas quem tanto ama a estética, deveria penetrar no segredo dessas existências, que são um poema de martírio cotidiano, de sacrifícios incalculáveis e de fadigas suportadas sem um murmúrio. Juventude, beleza, vestidos? Tiveram um instante de beleza e de juventude, foram amadas, casaram-se: depois, o marido, a miséria, o trabalho, as surras, o sofrimento e a fome. Têm filhos, mas precisam abandoná-los, o caçula entregue aos cuidados de uma irmãzinha, e como todas as outras mães, temem as carruagens, o fogo, os cães, as quedas. Estão sempre inquietas, agitadas, enquanto trabalham.

Lembro-me de uma mulher que tinha três filhos, um deles era especialmente muito bonito. $\mathrm{O}$ menino já tinha dois anos e ainda era amamentado, pois ela não tinha outra coisa para dar-lhe de comer: este pequeno esperava pela mãe, toda noite, sentado nos degraus do basso $^{28}$. O médico da assistência pública lhe dizia: «Pare de amamentálo, se não ele adoece.» Ela abaixava a cabeça: não podia tirar-lhe o leite. Um dia o menino pegou tifo e morreu. Descascando batatas, em uma cozinha, ela lamentava-se, murmurando: «figlio mio, figlio mio, io t'aveva da accidere, io t'aveva da fa murì! O che mamma cana che ssò stata! Figlio mio, e chi m'aspetta cchiù, la sera, mocc'a porta? ${ }^{29}$

$\mathrm{O}$ trabalho das crianças? Ah, as mães sentem-se muito felizes, quando o cocheiro de algum senhor admite como ajudante um garoto de doze anos, dando-lhe como pagamento apenas a comida; ou quando ele arruma ocupação em alguma oficina, onde o patrão o faz trabalhar como um animal e lhe dá apenas uma sopa no jantar; para o café da manhã, a bondosa mãe lhe dá um soldo.

As costureiras, as modistas, as floristas e fabricantes de envelopes admitem como aprendizes mocinhas de doze anos, que acabam sendo pequenas criadas que ganham cinco soldos por semana. Mas, em sua maioria, essas meninas ficam em casa ou na rua durante todo o dia.

\footnotetext{
${ }^{27}$ Sementes de melão ou melancia, favas e grãos de bico cozidos no forno.

${ }^{28}$ Basso: habitação tipicamente napolitana. Serao morou em um deles

${ }^{29}$ Em dialeto napolitano: Meu filho, meu filho, eu que te matei, eu que te fiz morrer! Oh, que mãe cruel que fui! E quem agora vai me esperar à noite?
} 
No campo, o filho é uma alegria, uma ajuda, uma fonte de prosperidade; em Nápoles representa uma preocupação a mais, uma pena materna, uma fonte de lágrimas e de fome.

Ouça com atenção quando uma operária napolitana fala de seus filhos. Ela diz le creature $^{30}$, e diz isso com uma doçura melancólica, uma piedade maternal e um amor tão dolorido que temos a impressão de conhecer de forma completa e profunda toda a intensidade da miséria napolitana.

\section{III - O QUE ELES COMEM}

Um dia, um empresário napolitano teve uma ideia. Sabendo que a pizza é uma das adorações culinárias napolitanas e que a colônia napolitana em Roma é imensa, pensou em abrir uma pizzaria na cidade. Ali podia-se encontrar pizzas de todos os tipos: pizza com tomate, pizza com muçarela e queijo, pizza com azeite e aliche, pizza com alho, óleo e orégano. O cobre das panelas e das formas reluzia, o forno não parava de arder; no início a presença do público era constante mas pouco a pouco começou a escassear. A pizza, distante de Nápoles, destoava do ambiente e representava uma indigestão; em Roma, a sua luz se ofuscou e desapareceu; planta exótica, morreu na solenidade romana.

De fato, é verdade: a pizza está na ampla categoria de alimentos que custam um soldo, e que fazem parte do café da manhã e do almoço, de boa parte do povo napolitano.

O pizzaiuolo que possui seu negócio faz, durante a noite, um grande número destas massas finas e redondas, de uma consistência densa, que se queimam mas não se cozinham, cobertas de tomate quase cru, alho, pimenta, orégano: estas pizzas cortadas em pedaços custam um soldo, são entregues a rapazes, que vão vendê-las em qualquer esquina, sobre uma banca ambulante e ali permanece durante quase todo o dia, com esses pedaços de pizza que ficam expostos ao frio e ao sol, cheios de moscas. Há também as fatias de dois centavos, para as crianças que vão à escola; quando o estoque acaba, mesmo que seja noite o pizzaiuolo providencia mais.

\footnotetext{
${ }^{30}$ No dialeto napolitano, significa criança.
} 
Durante a noite encontram-se também rapazes que carregam sobre a cabeça uma grande bandeja de estanho, dentro do qual estão as fatias de pizza. Eles circulam pelos becos e anunciam gritando que têm pizza com tomate e com alho, com muçarela e aliche. As pobres mulheres sentadas nos degraus do basso aproveitam para comprá-las e este pedaço de pizza é seu jantar (na verdade, o almoço).

Com um soldo, existem várias opções de almoço para o povo napolitano. No vendedor de frituras encontra-se um pacotinho de peixes que se chamam fragaglia e são o resto do cesto do vendedor de peixes: também no vendedor de frituras compra-se por um soldo, quatro ou cinco panzarotti, ou seja frituras nas quais se coloca um pedacinho de alcachofra, quando ninguém mais quer saber de alcachofra, um talinho de couve ou uma pitadinha de aliche. Por um soldo, uma velha vende nove castanhas cozidas, descascadas e banhadas em um líquido avermelhado: nesse caldo $o$ povo napolitano molha o pão e come as castanhas, como segundo prato; por um soldo, outra velha que arrasta um pequeno caldeirão em um carrinho, vende duas espigas de milhos cozidas. Em uma taberna, por um soldo, pode-se comprar uma porção de scapece, uma iguaria feita de abobrinhas ou berinjelas fritas no azeite e temperadas com vinagre, pimenta, orégano, queijo, tomate e oferecida na rua, em um recipiente grande e fundo, como una conserva, e do qual é retirada com uma colher. O povo napolitano leva o seu pedaço de pão dividido ao meio, sobre o qual joga a scapece. Nas tabernas, por um soldo, também se compra a spiritosa, que é feita de fatias de pastinaca ${ }^{31}$ cozidas na água e temperadas com um molho forte de vinagre, pimenta, orégano e pimentão. O proprietário fica na porta gritando: addorosa, addorosa, 'a spiritosa! ${ }^{32}$ Naturalmente, tudo isso é fortemente condimentado, de modo a satisfazer o mais fraco paladar meridional.

Quando tem dois soldos, o povo napolitano compra um prato de macarrão cozido e condimentado; em todas as ruas dos bairros populares há uma taberna, onde são colocados ao ar livre os caldeirões para cozinhar o macarrão, as panelas para o molho de tomate, as montanhas de queijo ralado, um queijo picante produzido em Cotrone $\mathrm{C}^{33}$.

\footnotetext{
${ }^{31}$ Legume semelhante à cenoura.

${ }^{32}$ Em dialeto napolitano: cheirosa, cheirosa, a spiritosa!

${ }^{33}$ Cidade da Calábria.
} 
Este aparato é, acima de tudo, muito pitoresco. Alguns pintores já retrataram essa cena, tornando-a bela e quase elegante, deixando o proprietário da taberna parecido com um pastor de Watteau; e na coleção de fotografias napolitanas, que os ingleses compram, ao lado da freira de casa, do ladrãozinho de lenços, da família de piolhentos, encontra-se também a banca do vendedor de macarrão. Estes pratos são vendidos em porções de dois e de três soldos; e o povo napolitano refere-se a eles pelo preço: nu doie e nu tre. ${ }^{34}$ A porção é pequena e o comprador briga com o vendedor porque quer um pouco mais de molho, um pouco mais de queijo e um pouco mais de macarrão.

Com dois soldos pode-se comprar um pedaço de polvo cozido na água do mar, temperado com pimentão fortíssimo. Esse comércio é feito pelas mulheres, na rua, com um fogareiro e uma pequena panela; com essa mesma quantia, compram-se os escargots com caldo, chamados de maruzze, e um biscoito para acompanhar. Por dois soldos o dono da taberna serve grandes colheradas de uma mistura quente e escura feita de restos de gordura de porco, miúdos, cebolinhas e pedaços de lula e a coloca sobre o pão do cliente, tomando cuidado para que esse caldo se deposite sobre o miolo e não escorra pelo chão, pois o comprador se preocupa muito com isso.

Quando tem três soldos por dia para almoçar, o bom povo napolitano, que se consome por saudades de sua família, não vai à taberna para comprar os alimentos prontos, mas almoça em sua própria casa, no chão, na soleira do basso, ou sentado em uma cadeira quebrada.

Com quatro soldos faz uma grande salada de tomates verdes crus e de cebolas; ou uma salada de batatas cozidas e beterrabas, de folhas de rabanete; ou com pepinos frescos.

As pessoas privilegiadas, que podem gastar oito soldos por dia, comem grandes pratos de sopa verde, feita de endívia, de couve ou de chicória, ou com todas essas verduras misturadas, a chamada minestra maritata; ou uma sopa de abóbora com muita pimenta, quando é época desse fruto; ou uma sopa de vagens com tomate; ou uma sopa de batatas cozidas com tomate.

Mas a maioria compra um rolo de massa de macarrão e o prepara com tomate e queijo. Essa massa, chamada monnezzaglia, de cor escura e de todos os tamanhos, é composta da coleta das sobras, ou seja, é o resto de toda a produção de massa.

\footnotetext{
${ }^{34}$ Em dialeto napolitano: O dois e o três.
} 
O povo napolitano é apaixonado por frutas, porém nunca gasta mais do que um soldo a cada compra. Em Nápoles, com um soldo é possível comprar seis peras um pouco estragadas, mas não importa; ou meio quilo de figos, um pouco amolecidos pelo sol; dez ou doze pequenas ameixas brancas, que pelo aspecto parecem ser daquelas que transmitem a febre; um cacho de uva escura, ou um melãozinho amarelo, pequeno, amassado, quase podre; ou duas fatias de melancia, daquelas não muito maduras, meio esbranquiçadas.

Outra iguaria apreciada pelo povo napolitano é o spassatiempo, feito com sementes de melão, favas e grãos de bico assados no forno; com um soldo pode-se comprar uma porção e beliscar durante parte do dia. Essas sementes irritam a língua e estufam o estômago, dando uma sensação de saciedade.

A iguaria mais apreciada é o soffritto: preparado com pedaços de carne de porco cozida com óleo, tomate e pimentão vermelho, formando uma pasta densa e vermelha, atraente aos olhos, e cortada em fatias que custam cinco soldos. Na boca, parece dinamite.

Questionário:

Guisado de carne? - O povo napolitano não come nunca.

Carne assada? - Às vezes, aos domingos, ou nas grandes festas, mas é de porco ou de cordeiro.

Caldo de carne? - O povo napolitano o ignora.

Vinho? - Algumas vezes aos domingos: o asprino, ${ }^{35}$ por quatro soldos o litro, ou o maraniello $^{36}$ a cinco soldos: este mancha a toalha de azul.

Água! - Sempre: e de má qualidade.

\footnotetext{
${ }^{35}$ Vinho produzido nas províncias de Caserta e Nápoles.

${ }^{36}$ Vinho da região da Campânia.
} 


\section{IV}

\section{OS ORATÓRIOS}

O senhor se surpreende com os oratórios? Espanta-se com a pequena procissão de mulheres descalças e descabeladas, que carregam uma imagem da Virgem e cantam salmos? A superstição do povo napolitano - oh, pobre gente que vive mal, mas com tanta bondade, que morre de um modo tão miserável e com tanta resignação! - a superstição desse povo causou uma dolorosa impressão em todos. Acreditava que houvesse cessado a superstição? Como pôde acreditar nisso? Então não se recorda de mais nada? Na epidemia de cólera de 1865 ocorreram procissões e orações públicas; no cólera de 1867, mais terrível e doloroso, ocorrido logo depois da guerra, de todas as paróquias saíam imagens da Virgem e dos santos protetores, as procissões encontravamse pelas ruas e misturavam-se: era como um mistério medieval e meridional. Assim como hoje Umberto de Savoia as encontra, há dezessete anos o grande rei Vittorio Emmanuele também as encontrou. $\mathrm{Na}$ assustadora erupção de 1872, por três dias seguidos a lava ameaçou Nápoles: as mulheres do povo foram à Catedral para levar a cabeça de são Gennaro, pois queriam circular com ela para fazer cessar a lava. Por um momento os nobres responsáveis pelas relíquias e os clérigos da catedral não permitiram. No quarto dia não saiu o sol; uma densa nuvem de cinzas cobriu Nápoles e começou a chover cinzas, como em Pompeia; as mulheres de todos os bairros populares realizaram procissões, chorando e gritando em uma lúgubre tristeza. Durante a epidemia de cólera de 1873, menos devastadora do que as anteriores mas mesmo assim perigosa, foram realizadas nos quatro bairros populares procissões à Nossa Senhora de Banchi Nuovi, à Virgem de Portosalvo no Porto, a Jesus de Colonna, da igreja no beco da Universidade. Que fugaz é nossa memória!

E a vida cotidiana? Olhando a nossa volta e observando o que acontece, mesmo superficialmente, não é possível acreditar que a exaltação religiosa do povo napolitano tenha acabado. Esses oratórios com velas acesas estão por todas as esquinas dos bairros populares, e em algumas festas. São feitos pelas crianças menores, na verdade: mas as mães sempre os vigiam, enquanto as irmãs mais velhas pedem o óbolo aos passantes, entre risos e orações. Para as festas maiores, com lanterninhas e guirlandas multicoloridas, as pessoas juntam suas economias durante um ano, e um beco sempre 
quer fazer melhor do que o outro: por conta dessa rivalidade acontecem discussões e brigas com facas. Essas pitorescas competições causam o êxtase dos artistas - essa raça de egoístas - que dedicam a vida à contemplação de seu Buda: a arte. Outro costume: quando uma mulher se salva de uma grave enfermidade, para agradecer a Deus, faz a promessa de sair pedindo esmolas, por todas as casas de seu bairro; sobe, desce, com as pernas frágeis, o rosto pálido, recebendo ásperas recusas e portas batidas na cara. Não importa, é preciso suportar, é a promessa. Tudo o que arrecada, leva à igreja. Quando uma criança adoece, é oferecida a são Francisco: após seu restabelecimento, o pequeno é vestido como um monge, com uma túnica simples, o cordão na cintura, os pezinhos nus nas sandálias e o alto da cabeça raspado. Quem nunca os viu nos bairros populares?

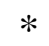

Com o milagre de san Gennaro, o senhor se maravilha? O senhor se surpreende com aquelas velhas moradoras do Cais que se dizem suas descendentes e invadem o altar mor, sem deixar que ninguém se aproxime, gritam o Credo, enquanto aguardam o milagre, e a cada vez que recomeçam a reza, elevam o tom até berrar, que se agitam como obsessivas, que o chamam de velho despeitado, velho impertinente, cara verde? Podemos enumerar muitas outras crenças: o pé de sant'Ana, que é colocado sobre o ventre das parturientes que não conseguem dar à luz; existe também o óleo que arde na lâmpada diante do corpo de são Tiago das Marcas, na igreja de Santa Maria Nova, que cura as dores de cabeça; ou o Crucifixo do Carmo, cujas chagas sangraram; o bastão de são Pedro venerado na igreja subterrânea de São Aspreno, primeiro bispo de Nápoles, no bairro Mercanti; a benta de São Biagio dos Livreiros que cura a dor de garganta; existem as panelle, pãezinhos benzidos de São Nicolau de Bari que não são atingidos pelos raios durante um temporal. Existem centenas de ossinhos, pedacinhos de véu, pedacinhos de roupa ou fragmentos de madeira que são relíquias. Todas as napolitanas carregam no pescoço, amarrado na cintura ou colocado sob o travesseiro um saquinho de relíquias, de orações impressas: este saquinho é preso às faixas do bebê, assim que ele nasce.

Acredita que para o napolitano a Virgem do Carmo seja suficiente? Eu contei duzentos nomes para a Virgem, e estes não são todos. Quatro ou cinco são considerados os mais importantes. Quando uma napolitana adoece ou corre um grave perigo, alguém de sua família faz promessa a uma destas Virgens. Depois cumpre a promessa trajando um vestido novo, benzido na igreja, que só deve deixar de usar quando estiver velho. 
Para a Virgem das Dores o vestido é negro, com listras brancas; para a Virgem do Carmo, é cinza com listras brancas; para a Imaculada Conceição, branco com listras azuis; para a Virgem de Salete, branco com listras cor-de-rosa. Quando não têm dinheiro para fazer o vestido, fazem o avental; se não cumprem a promessa, temem desventuras em casa.

E o sagrado se mistura ao profano. Para conseguir um marido, é necessário fazer a novena a são João, por nove noites, e rezar certas antífonas especiais, em uma varanda, sempre à meia-noite. Quem tiver a coragem de fazê-lo, na nona noite verá uma trave de fogo através do céu, sobre a qual dançará Salomé, a bailarina maldita: a voz que se ouve logo em seguida pronuncia o nome do marido. São Pascoal também é protetor das jovens que procuram um marido e é necessário repetir por nove noites a seguinte antífona: Ó beato são Pascoal - mandai-me um marido - belo, vermelho, colorido - como vós tal e qual - ó beato são Pascoal! - São Pantaleão também protege as jovens, mas em modo diverso: dá a elas os números da loteria para que possam adquirir o dote e casar-se. A jovem deve rezar durante noves noites, sozinha em um quarto, com a janela e a porta abertas, à meia-noite, e após a Ave-maria e o Pai Nosso proferir a seguinte antífona: meu são Pantaleão - pela vossa castidade - pela minha virgindade dai-me os números, por caridade! Na nona noite, ouvem-se passos: é o santo que chega, e através de batidas, revela os números. Após quatro ou cinco noites destes estranhos rituais, as jovens ficam tão exaltadas que passam a ter alucinações e convulsões. Algumas afirmam ter visto e ouvido qualquer coisa na nona noite, mas que lhes faltou fé e o milagre não aconteceu.

Todas as superstições espalhadas pelo mundo existem também em Nápoles, mas aqui são ampliadas, multiplicadas. Todos nós acreditamos na jettatura. ${ }^{37} \mathrm{Nem}$ falamos do óleo derramado, do espelho quebrado, da colher cruzada com a faca, da combinação vestida do avesso que provoca azar, do dinheiro marcado (corcundas) ${ }^{38}$, das aranhas, dos escorpiões, da galinha: velhas superstições, quem se importa com elas? Os napolitanos acreditam ainda nas sibilas ${ }^{39}$ : existe uma chamada Chiara Stella na Cento Strade, na direção de Corso Vittorio Emmanuele, e a siè Grazia, no Beco Mezzocannone, ambas muito famosas, além de muitas outras menores. As pessoas deixam a elas cinquenta centavos, duas ou cinco liras. Os napolitanos acreditam nos

\footnotetext{
${ }^{37}$ Influxo maléfico que segundo a crença popular algumas pessoas podem exercer sobre outras.

${ }^{38}$ Acreditava-se que os corcundas trouxessem sorte.

${ }^{39}$ Personagens da mitologia grecorromana, com poderes proféticos.
} 
espíritos. O espírito familiar napolitano que circula em todas as casas, é o monaciello, um garotinho vestido de branco quando traz sorte, vestido de vermelho, quando traz desventura. Muitas pessoas me garantiram tê-lo visto. No centro de Nápoles, na ladeira de Santa Teresa, um belíssimo palacete nunca mais foi alugado: está fechado há vinte anos, pois está ocupada pelos espíritos. O napolitano acredita nos espíritos que revelam os números, acredita nos assistidos: os assistidos são um tipo de gente muito estranha, alguns agem de boa fé, outros são aproveitadores. Comem pouco, bebem água, falam por enigmas, dormem sem comer e têm visões. Vivem sempre junto dos jogadores, mas nunca apostam. Às vezes os jogadores decepcionados agridem o assistido, para depois pedir-lhe perdão. Os monges também têm visões. Existia um muito famoso, em Marano de Nápoles: as pessoas faziam peregrinação até ele. Outro jovem igualmente famoso vivia no convento de São Martinho. Às vezes os jogadores sequestram, agridem e torturam o monge. Um deles chegou a morrer. Antes de expirar, pronunciou os números. As pessoas apostaram neles e acabaram sendo sorteados. Metade de Nápoles venceu na loteria, pois um jornal havia publicado esses números.

O povo napolitano, principalmente as mulheres, acredita na bruxaria. A feitiçaria encontra apóstolos fervorosos: as feiticeiras, ou bruxas, são inúmeras. Uma mulher deseja que seu marido, que vai para longe, permaneça fiel? A bruxa lhe dá um cordãozinho com nós, é necessário costurá-lo no forro do casaco do marido. E se quer conquistar o amor de um homem? A feiticeira queima uma mecha dos seus cabelos, mistura a certos ingredientes, fazendo um pozinho: esse preparo deve ser colocado no vinho do homem indiferente. Quer vencer um processo? É preciso amarrar, moralmente, a língua do advogado contrário: fazer quinze nós em um barbante, chamar o diabo, um esconjuro terrível. Quer que morra um amante infiel? Deve-se colocar dentro de um pequeno caldeirão algumas ervas venenosas, fervê-las diante de sua porta, à meia-noite. Quer que uma mulher rival morra? Deve-se espetar alfinetes em um limão fresco de modo a formar um desenho da rival, prender um pedaço do seu vestido e finalmente jogar tudo no seu poço. A feitiçaria possui um amplo desenvolvimento; uma literatura estranha, por vezes ignóbil, de esconjuros e orações; possui uma classificação, para as almas tímidas e para as almas corajosas: está espalhada em todos os bairros; possui um alívio para todas as necessidades sentimentais e brutais, para os bons e maus desejos.

Isto é tudo. Ou melhor, não é tudo. Exagere vinte vezes tudo o que lhe disse: talvez, não fosse verdade. Esta mistura confusa de fé e engano, de misticismo e sensualidade, este culto externo tão pagão, esta idolatria, o assustam? Lamenta estas 
coisas, dignas dos selvagens? Mas quem fez algo pela consciência do povo napolitano? Quais ensinamentos, quais palavras, quais exemplos pensou-se em dar a esta gente tão expansiva, tão fácil de conquistar, tão naturalmente entusiasta? Na verdade, em meio à miséria profunda da sua vida real, eles não tiveram outro conforto a não ser as ilusões da própria fantasia e outro refúgio além de Deus.

\section{V}

\section{A LOTERIA}

No sangue deste povo excepcionalmente meridional, se cruzam e se fundem as nobres, poéticas e ardentes heranças etruscas, árabes, sarracenas, normandas e espanholas. Por isso o rico sangue napolitano se inflama no ódio, arde no amor e se consome no sonho: a este povo, para quem a imaginação é a mais alta, álacre e inexaurível potência da alma, uma grande fantasia deve ser permitida.

É uma gente humilde, de bom coração, que seria feliz com pouco mas nada tem para ser feliz, que, suporta com doçura e paciência, a miséria, a fome cotidiana, a indiferença daqueles que deveriam amá-la, o abandono daqueles que deveriam salvá-la.

Embora seja feliz vivendo ao ar livre, um hábito herdado dos povos orientais, não tem ar; apaixonada pelo sol, não tem sol; apaixonada pelas cores vibrantes, vive na escuridão; por herança da bela civilização anterior, a grega, ama os pórticos brancos que se destacam contra o azul do céu, mas as tocas onde moram essas pessoas não parecem ter sido feitas para os humanos, e dos frutos da terra, fica com os piores, aqueles que no campo são dados aos porcos; e alguns alimentos não experimenta nunca.

No entanto, o povo napolitano renova a cada semana o seu grande sonho de felicidade, vive durante seis dias em uma esperança crescente, invasora, que vai se ampliando até sair dos limites da vida real: por seis dias, o povo napolitano sonha o seu grande sonho, de obter todas as coisas que não possui: uma casa limpa, ar puro e fresco, um belo raio de sol, uma cama branca e alta, uma cômoda brilhante, macarrão, carne e um litro de vinho todo dia, o berço para o bebê, o enxoval para a mulher e o chapéu novo para o marido.

Todas as coisas que a vida real não the pode dar, e que não lhe dará nunca, permanecem na sua imaginação, de domingo até o sábado seguinte; falam dos projetos e sentem-se tão seguros, que eles quase se tornam reais e por causa disso marido e mulher brigam ou se abraçam. 
Às quatro da tarde de sábado, a desilusão é profunda, a desolação não tem limites: mas no domingo pela manhã, a fantasia renasce, mais forte, o sonho semanal recomeça. A loteria, a loteria é o grande sonho, que consola a fantasia napolitana: é a ideia fixa dessas mentes inquietas; é a grande visão feliz que satisfaz o povo oprimido; é a profunda alucinação que arrebata as almas.

$$
\begin{aligned}
& * \\
& * *
\end{aligned}
$$

E é contagiosa esta doença do espírito: um contágio sutil e infalível, inevitável, cuja força de difusão não pode ser calculada. Do sapateiro sentado diante do portão, o contágio da loteria se transmite à pobre costureira que lhe traz os sapatos velhos para consertar; desta passa a seu namorado, um ajudante de serviços; este o leva ao proprietário da taberna que dá a todos os clientes, que por sua vez semeiam nas casas, nas oficinas, nas outras tabernas, até nas igrejas.

A criada do quinto andar, à direita, aposta, esperando poder parar de trabalhar; mas todas as criadas, de todos os andares, apostam, tanto a camareira do primeiro andar que ganha trinta liras por mês, quanto a vajassa ${ }^{40}$ do sexto, que ganha oito, com a doce esperança de deixar o trabalho, que é tão duro; e discutem os números entre si, reunindo-se nas escadarias, comunicando-se pelas janelas ou através de sinais. A vendedora de frutas, que trabalha sob chuva ou sol, também joga, assim como todas as outras que trabalham na mesma rua: a mulher do alfaiate, que costura na porta, a mulher do funileiro sufocada pelo cheiro de chumbo, a lavadeira que fica o dia todo com as mãos mergulhadas no sabão, a vendedora de castanhas que tem o rosto e as mãos queimados pelo vapor e pelo calor do fogareiro, a vendedora de nozes, com as mãos escurecidas pelo ácido gálico. Todas estas mulheres acreditam na loteria, jogam fiel e ardentemente na loteria.

Na pequena oficina de costura, todas as jovens que ali trabalham também jogam. Enquanto duas revelam suas apostas e a maesta ${ }^{41}$ garante saber os verdadeiros números, em um canto está o berço onde dorme o bebê de uma delas e em outro uma frigideira com toucinho.

As cabeleireiras do povo, as chamadas capere, que ganham um soldo por dia e andam com o avental enrolado em torno da cintura, cabelos desarrumados e mãos

\footnotetext{
${ }^{40}$ Dialeto napolitano: significa criada ou doméstica. Recentemente usado come sinônimo de mulher de baixa condição.

${ }^{41}$ Em dialeto napolitano: mestra.
} 
engorduradas, fazem circular os números entre suas clientes e em troca recebem outros. Elas são as porta-vozes dos números. Em todas as oficinas onde os operários napolitanos são mal remunerados por um trabalho penoso, a loteria lança raízes profundas; em todas as escolas populares jogam tanto as professoras quanto as alunas maiores, reunindo o dinheiro do café da manhã. Nos locais onde se concentram as desgraçadas mulheres que vivem de pecado e que em Nápoles são tão comuns, a loteria é uma das maiores esperanças: a esperança de redenção.

$$
\begin{gathered}
* \\
* *
\end{gathered}
$$

Mas não pense que o mal se limite às classes populares. Não, não, ele vai mais além, assola as classes médias, penetra em todas as burguesias, em todos os comércios, chega até a aristocracia. Onde existe uma necessidade mantida em segredo, onde existe um desfalque que não é possível compensar, uma ruína financeira em sigilo porém iminente, um desejo impossível ou a dureza oculta da vida mais se torna presente e onde apenas o dinheiro pode ser a solução, o jogo da loteria toma posse, domina.

Secretamente, jogam todas as jovens solteiras que não têm um soldo de dote; jogam os inúmeros funcionários do Município, dos Bancos, da Intendência ${ }^{42}$, do Imposto sobre o Consumo; todos os aposentados que não conseguem viver com a pensão e que por não terem nada a fazer fazem a cabala, estudam a ciência necromântica da loteria, jogam desesperadamente e estão sempre com bens no penhor; todos os funcionários de lojas, que ganham quarenta liras por mês, sabem os números certos e jogam toda semana. Um grande lucro à loteria fornecem os magistrados: miseravelmente pagos, eles que representam a maior equidade moral, expostos a tentações que afastam com uma inflexibilidade digna de melhor remuneração, com uma família numerosa, arruinados pelas contínuas mudanças, sua fraqueza, sua esperança consiste na loteria.

Os pequenos comerciantes que se esforçam continuamente para pagar contas e lutam diariamente para escapar da falência, acabam apegando-se a esta incerta tábua de salvação da loteria; os grandes jogadores da bolsa, que não só vivem mas são até capazes de dançar uma valsa sobre o fio da navalha e, impelidos pela febre do jogo, saboreiam a esperança da loteria. Conheço todos estes sintomas do mal característicos das classes dirigentes por ter visto, ouvido, compreendido e intuído.

\footnotetext{
42 Órgão responsável por licitações, contabilidade e fornecimento.
} 
As senhoras da aristocracia jogam por brincadeira, por desejo de uma nova pulseira ou por preocupação com um débito com a costureira que o marido não pagará. Até mesmo aqueles que deveriam escapar ilesos, por estarem habituados ao mal, por estarem envolvidos nisso, os empregados dos pontos de loteria, os postieri, não conseguem resistir à tentação. Assim, às quatro horas do sábado, os mais fanáticos, que não conseguem mais esperar, dirigem-se à Agência, em uma rua estreita entre a rua Pignatelli e a rua de Santa Clara, para assistir à extração dos números.

No entanto, as criadas, as vendedoras, as operárias e os operários, as jovens e os empregados não podem sair de seus respectivos trabalhos. Então um moleque dirige-se ao ponto de loteria mais próximo e pega os números enquanto todos esperam. As pessoas mais corajosas ficam nas portas e nas janelas, enquanto os envergonhados não saem, mas tentam aguçar os ouvidos. O rapaz volta correndo, ofegante, posiciona-se na entrada do beco e grita os números, com voz potente:

"Vintiquatto!"

"Sissantanove!"

"Quarantanoie!"

"Otto!"

"Sittantacinche!"

Silêncio geral: todos empalidecem.

Mas como todos os sonhos muito evidentes, a loteria conduz à inatividade e ao ócio: como todas as visões, leva à falsidade e à mentira; como todas as alucinações, conduz à crueldade e à violência; como todos os remédios ilusórios nascidos da miséria, produz miséria, degradação e crime.

O povo napolitano, que é sóbrio, não se deixa corromper pela aguardente e não morre de delirium tremens; porém, deixa-se corromper e morrer pela loteria. A loteria é a aguardente de Nápoles. 
A loteria possui uma primeira forma literária e rudimentar baseada na tradição oral como certas fábulas e lendas. Todos os napolitanos que não sabem ler, os velhos, as crianças, e sobretudo as mulheres sabem de cor a smorfia, isto é, a Chave dos sonhos $e$ rapidamente aplicam seu conteúdo a qualquer sonho ou situação da vida real. Sonhou com um morto?- quarenta e sete - mas falava - então quarenta e oito - e chorava sessenta e cinco - e causou medo - noventa. Um jovem foi apunhalado por uma mulher? - dezessete, a desgraça - dezoito, o sangue - quarenta e um, o punhal - noventa, o povo. Se cai uma panela que estava pendurada, uma criança adoece, foge um cavalo, aparece um grande rato: números, antes de tudo.

Todos os acontecimentos, grandes e pequenos, são considerados uma misteriosa fonte de lucro. Morre uma jovem de tifo; a mãe aposta os números e se são sorteados, ela exclama: $m$ 'ha fatte bbene pure murenne $!^{43}$ Uma mulher fala do amor que seu marido, já falecido, tinha por ela; em seguida acrescenta melancolicamente, que se este amor fosse mesmo grande, ele apareceria em seus sonhos para dizer-lhe os números; e se houver esquecido, é um ingrato, pois ele sabe o quanto ela é pobre e que deveria ajudá-la.

Salvatore Daniele esquarteja Gazzarra ${ }^{44}$ : um bilhete; o povo diz: chella ̀̀ mmorta, mo,almeno ce refrescasse a nnuie, che simmo vive. ${ }^{45}$ Salvatore Misdea ${ }^{46}$ mata sete soldados: um bilhete. Misdea é condenado à morte: um bilhete. Nas portas, nos bassi, nas esquinas, os números são discutidos pelos grupos e subgrupos; o bilhete é decidido. Não sai: haviam se enganado, deviam jogar este ou aquele outro número, que saíram.

Esta ciência da smorfia é tão profunda e habitual, que para chamar alguém de doido se diz: è $n u$ vintiroie (vinte e dois, louco), e quanto maior for a raiva, todas as injúrias que têm um número correspondente são ditas na gíria da loteria. Uma mulher agride outra, quebrando-lhe a cara; diante do juiz, desculpa-se, dizendo: $m^{\prime} h a$

\footnotetext{
${ }^{43}$ Dialeto napolitano: Me fez bem até mesmo depois de morta!

${ }^{44}$ Salvatore Daniele foi condenado à morte em 1877 por ter assassinado a amante Giuseppina Gazzarra e ocultado seu cadáver em um baú.

45 Dialeto napolitano: Ela está morta, agora, poderia ao menos dar uma ajuda a nós, que estamos vivos.

${ }^{46}$ Salvatore Misdea (Girifalco, 1862-1884) soldado calabrês que assassinou colegas em um quartel de Nápoles, em 1884. A desavença teria sido iniciada porque Misdea e outros soldados eram vítimas de preconceito por serem de origem meridional. Durante seu julgamento, Cesare Lombroso contribuiu para a sua condenação à morte apresentando-o como um criminoso nato.
} 
chiammata sittantotto $^{47}$; o juiz deve consultar a smorfia e ver a qual ofensa corresponde este número.

A cabala é mais importante para a classe superior que para a inferior: mas foi nesta que se originou. Claro que o povo não compra jornais cabalísticos semanais, com estranhos títulos: il Vero amico, il Tesoro, il Fulmine, il Corno d'abbondanza, cuja assinatura custa dez liras por ano, elaborados por uma redação desconhecida; o povo também não envia correspondência àqueles professores de matemática que moram na rua Nocelle doze, ou em São Libório, quarenta e oito, ou na rua Zuroli, três, e que oferecem, nas quartas páginas, a fortuna a quem paga dez liras. Mas alguma coisa escapa: qualquer pessoa que saiba os números será esperada nas ruas e receberá em troca disso algumas liras, satisfazendo-se com isso: é um pequeno negócio.

$O$ assistido (pelos espíritos) é um câncer que assola as famílias burguesas, um convulsionário pálido que come muito, finge ter ou tem alucinações, não trabalha, fala através de enigmas, faz acreditar em cruéis penitências e vive às custas daqueles que o veneram. Mas através da camareira, do criado e da lavadeira que trabalham na casa burguesa a reputação do assistido chega ao povo; e assim ele amplia a sua ação mística, obtendo ganhos pequenos porém inesperados, reunindo adeptos e caminhando pelas ruas, sempre rodeado de quatro ou cinco pessoas, que o bajulam e analisam todas as suas palavras.

O grande auxiliador do povo, a providência do povo, a sua fé, a sua crença indestrutível, é o monge. O monge sabe os números: este é o dogma. Se não os diz é porque o Senhor lhe proibiu de ajudar os pecadores; se os diz mas não são sorteados, é porque faltou a verdadeira fé no apostador; se os diz e são sorteados, a novidade se espalha em um minuto, o pobre monge fica aflito com essa perigosa popularidade. É como o artista que produziu uma obra de arte: infeliz se não continuar a produzir outras semelhantes, está perdido. O monge que adivinhou apenas um par, tem esperança de viver em paz: mas aquele que acertou três números, é melhor que fique atento. Tentarão

\footnotetext{
${ }^{47}$ Dialeto napolitano: Me chamou de setenta e oito. O número representa a prostituta.
} 
aliciá-lo de todos os modos, com doações de dinheiro, presentes, ofertas, missas, esmolas; pedirão para que ele reze pelas crianças, pelas mulheres, pelas velhinhas; ficarão à sua espera na rua, na porta da igreja, junto ao confessionário, na porta do convento; pedem ajuda a sua mãe, seu irmão ou sua tia. $\mathrm{O}$ monge será assediado noite e dia; estará sujeito a ser espancado, sequestrado, torturado, e até a passar fome, para que revele os números agonizando. Estas coisas já aconteceram. Muitas vezes, para salvarse, ele solicita transferência de cidade a seu superior; quando desaparece, o povo diz que a Virgem o levou embora.

O povo napolitano aposta na proporção de suas possibilidades. Mesmo que seja pobre, encontra sempre seis soldos, meia lira, aos sábados, para jogar; recorre a todos os expedientes, inventa, procura, acaba encontrando. O cúmulo da miséria não consiste em dizer que não almoçou, mas em dizer: Nun, m'aggio potuto jucà manco nu viglietto ${ }^{48}$; quem ouve, fica surpreso. Entre a noite de sexta e o sábado de manhã, observa-se uma agitação de gente que quer jogar mas não tem dinheiro; os operários pedem adiantamento do pagamento de uma jornada, as criadas roubam descaradamente nas compras, os pedintes pelas ruas aumentam de forma evidente entre sexta e sábado, vende-se aquilo que se pode vender, penhora-se aquilo que se pode penhorar.

Antes de tudo, existem os bilhetes populares, aqueles que se jogam sempre, porque é uma tradição, porque é uma obrigação, porque não se pode deixar de jogar: o par famoso, seis e vinte e dois; o terno famoso, cinco, vinte e oito e oitenta e um; o terno da Virgem, oito, treze e oitenta e quatro. Estes ternos, para sorte do governo, só são sorteados uma vez a cada vinte anos: quando saiu, depois de muitos anos de espera, o par seis e vinte e dois, o governo pagou dois milhões em pequenos prêmios, de cinco e dez liras cada; e em toda Nápoles ocorreram pequenos banquetes, ou seja, todos almoçaram ou jantaram com o prêmio, e recomeçaram a jogar, com maior ardor na semana seguinte.

Todos têm seu bilhete especial, que jogam uma vez por semana durante anos, com uma fé indestrutível: um engraxate jogava o mesmo número que seu pai ao morrer, havia deixado de herança, juntamente com a caixa para engraxar; foram sorteados alguns pares, três ou quatro vezes, ao longo de trinta anos; o terno, nunca.

\footnotetext{
${ }^{48}$ Não pude jogar nem um bilhete.
} 
Um porteiro apostou os mesmos números, durante quarenta e cinco anos, sem nunca ganhar nada: na primeira vez em que, por um motivo particular, se esqueceu, o terno foi sorteado - o homem morreu de desgosto.

Sempre há um bilhete que faz referência a um grande acontecimento, discussão ou suicídio, tiroteio ou envenenamento; e existe também o bilhete cabalístico, arrancado do assistido ou do monge.

Estes quatro tipos de bilhetes devem ser jogados cada um a seu modo; custam entre cinquenta centavos e duas liras por semana. Quando o napolitano não tem mais do que dois soldos, aposta no jogo pequeno, a loteria clandestina.

A maior parte das intermediárias desta grande fraude são as mulheres. Uma delas, suja, esfarrapada, leva no bolso, sob o saiote, um registro: o jogador ou a jogadora, deposita dois soldos e diz os números: em troca recebe um pedaço de papel sujo, onde estão escritos a lápis os números e a promessa, invariável: um escudo o par... quarenta escudos o terno. A mulher circula por todo o bairro, todos a conhecem, esperam e sabem qual sua profissão: alguém a denuncia? Ninguém ousaria, é uma benfeitora.

Esses lucros são vastos naturalmente; de dois em dois soldos é possível acumular centenas de liras: quase todos os mantenedores do jogo pequeno enriquecem.

$\mathrm{Na}$ Riviera podem ser vistas as embarcações dos ricos, que obtiveram riqueza com a loteria clandestina; as pessoas que trabalham com isso são bem conhecidas, mas nunca aparecem, pois possuem os seus agentes. Os homens do povo possuem uma fé cega nos mantenedores do jogo pequeno: mas é muito comum que o mantenedor fuja com todos os seus registros na tarde de sábado quando precisa pagar muitos prêmios. Isso importa?

Uma semana depois outra mulher recomeça a circular e as pessoas caem novamente, como seduzidas, invencivelmente. Que delícia para quem joga e para quem ganha o dinheiro, fraudar o governo!

De vez em quando a polícia prende quatro ou cinco destes agentes, destas intermediárias, que são condenados à prisão ou a pagar uma multa; alguém se importa? Descontam a pena, pagam a multa, ficam livres, e recomeçam tudo com mais 
entusiasmo. Há pessoas que foram condenadas cinco vezes por jogo pequeno: mas possuem uma mansão e queixam-se da perseguição do governo, considerando a sua condenação na disgrazia. Fixar o preço do bilhete a dois soldos não valeu nada para o governo: a fraude continua, mais forte, apoiada nesta grande alucinação.

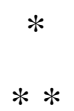

As estatísticas informam que às quintas, sextas e sábados, acontecem mais furtos domésticos; que nestes três dias também aumentam os penhores no Monte di Pietà e as agências privadas de penhores ficam lotadas; que nestes três dias, mas sobretudo sábado à tarde, acontecem mais brigas; que as coisas mais horríveis, torpes, ignóbeis e violentas acontecem nesse período fatal. Nestes dias, o povo napolitano cai nas garras da usura: o verdadeiro câncer que o mata.

\section{VII}

\section{A USURA}

Uma mulher pobre que precisa de cinco liras para pagar o aluguel vai pedir emprestado a dona Carmela, que dá o dinheiro cu a credenza. ${ }^{49}$ Hesita muito antes de ir, sente medo e vergonha, mas acaba se decidindo já que não lhe resta mais nada a fazer. Dona Carmela é uma mulher grande e gorda que exerce na maior parte do tempo uma profissão de prestígio, remenda as rendas, borda os grandes mantos de lã que se usam em Nápoles, no inverno faz bordados em ouro sobre veludo: uma profissão de fachada, que permite que ela usufrua longos períodos de ócio; mas a sua verdadeira profissão é o empréstimo de dinheiro aos pobres. Dona Carmela é falante e afetuosa nesse primeiro encontro com a pobre mulher: conforta, mostra empatia, se for preciso, confessa que também já passou por uma situação difícil, e a manda embora, toda resignada, com as cinco liras, - ou melhor com quatro liras e meia. $\mathrm{O}$ empréstimo é feito por oito dias, os juros são de dois soldos por lira. O pagamento é antecipado: portanto, sobre as cinco liras, a pobre mulher deixa cinquenta centavos. Os oito dias se passam, a pobre mulher não possui as cinco liras para devolver e, assim, completamente envergonhada, implora a dona Carmela que fique apenas com os juros decorrentes de uma outra semana, cinquenta centavos: dona Carmela não diz nada e embolsa os dez

\footnotetext{
${ }^{49}$ Dialeto napolitano: a crédito.
} 
soldos. Assim se passam quatro, cinco, até dez semanas, sem que a pobre mulher consiga economizar as cinco liras: e toda segunda-feira deve pagar os dez por cento de juros da semana, e após a quinta semana dona Carmela comporta-se como uma fera, é preciso pedir-lhe para que não grite, para que não faça cenas, ela quer seu dinheiro, quer seu sangue, os juros não lhe interessam, precisa do dinheiro do capital. Na soleira das portas, nas portas das oficinas, todo sábado, toda segunda, ouve-se a voz irada de dona Carmela: desde cedo, ela circula para exigir, recolher, aterrorizando homens e mulheres, com seu tom alto e imperioso. Em um lugar exige uma lira, em outro duas, em outro cinco: e ninguém ousa rebelar-se, pois não têm como pagá-la mas sempre podem precisar dela. Essa gorda mulher é implacável: é consciente de seu poder: se uma criada não paga, ameaça fazer um escândalo com a patroa, se uma mulher não paga, ameaça contá-lo ao marido, se um operário não paga, ela sabe o endereço do chefe, a quem vai denunciá-lo. Ela é astuta e cautelosa, audaz e desbocada: coloca-se sempre na posição de benfeitora destes ingratos que roem seu osso e bebem seu sangue. Mesmo assim ninguém lhe dá uma facada, ninguém lhe dá uma surra ou a insulta, e o mais impressionante, ninguém tem a coragem de negar-lhe o dinheiro: a honestidade do povo napolitano não é capaz de ludibriar uma usurária. Não consideram errados nem mesmo os seus escândalos: e procuram sempre acalmá-la.

Quando uma pobre mulher napolitana precisa de um avental, um vestido, um lenço ou uma camisa e não tem dinheiro para comprá-los, decide procurar dona Raffaela que lhe fornece a mercadoria cu a credenza. ${ }^{50}$ Esta outra usurária adquire, a baixo preço, tecidos, percal e lenços de algodão das lojas: e revende a essas pobres pessoas. Toda mercadoria, naturalmente, acaba custando muito mais do que o verdadeiro preço: este é seu primeiro ganho. Em seguida, como faz a outra usurária, exige o pagamento dos juros de dez por cento por semana, sobre a soma. Estas dívidas, que se avolumam continuamente, pesam sobre a existência dessas infelizes, por meses a fio: de modo que, muitas vezes, quando o avental está gasto, a roupa rasgada e as camisas com buracos a pobre mulher já pagou três vezes o valor deles, e a dívida permanece igual: dona Raffaela fica furiosa, grita como uma endemoniada, quer arrancar da mulher o lenço ou o avental que lhe vendeu e grita : Chesta è robba mia! $T^{\prime}$ aie arrobbato lu sango mio! ${ }^{51}$ Como a outra, acaba embolsando quatro ou cinco vezes o capital; como a outra, é necessária aos pobres, que nunca reagem a este tipo de

\footnotetext{
${ }^{50}$ Dialeto napolitano: a crédito

${ }^{51}$ Dialeto napolitano: Estas coisas são minhas! Você tirou meu sangue!
} 
violência; como a outra, arrisca apenas pequeno capital, preferindo fazer inúmeros pequenos negócios, nos quais não existam riscos, ao invés de envolver-se em grandes negócios que ofereçam perigos.

As agências particulares de penhor representam a usura legalmente organizada. Não são sucursais do Monte di Pietà, e por isso suas tarifas não são as mesmas exercidas pelo grande instituto de misericórdia; mas são especulações devidamente autorizadas e mantidas com capital próprio. Em sua maioria são administradas por mulheres, profundamente sutis em sua vulgaridade e ignorância, e são abertas com pouco capital. Nestas agências, acima de tudo o objeto é extremamente desvalorizado, principalmente se não for ouro: e disto resulta o primeiro lucro. Paga-se um fantástico direito de registro, e mais um tanto pela cartela, além dos juros adiantados por um mês, tudo tão complicado e bem salvaguardado, tão aparentemente legal, que estas agências exigem cinco por cento de juros por mês, sem que ninguém tenha o direito de lamentarse. Soube da esposa de um empregado que precisou penhorar o seu único vestido de seda, o vestido de noiva, que custou duzentas e cinquenta liras, em uma destas agências, mantida por uma grande dona Gabriela: obteve trinta e seis liras, das quais retirou apenas trinta e uma, deixando cinco pelos juros, pela cartela e pelo direito de registro. Por seis meses, tremendo para que não vendessem o seu vestido e sem ter as trinta e seis liras, teve que pagar todo mês, cinco liras, ou seja, devolveu o dinheiro adquirido: sete meses depois não obteve nem as cinco liras e o vestido foi vendido. Foi verificar se era possível conseguir mais dinheiro, já que o vestido era novo, e devia ter sido vendido por uma boa quantia: tinha sido liberado por trinta liras; pelo menos era isso que estava registrado no livro. Teve depois o prazer de encontrar dona Gabriela no teatro trajando seu vestido e coberta de ouro e jóias, compradas de novo da agência. Como muitas delas adoram andar carregadas com os objetos que lhes deixam em depósito, e é comum que as mulheres do povo vejam a credora passeando, e levando no pescoço o cordãozinho de ouro que ela precisou penhorar, nas orelhas os brincos da vizinha, e nas costas o xale de veludo da senhora do terceiro andar: e atrás das portas, e das janelas, quando a credora passa, ouvem-se suspiros reprimidos, lágrimas contidas, súbita palidez: a credora é como um ídolo indiano ao qual sacrifica-se ouro e sangue. Algumas credoras, mais astutas e calculistas, penhoram de novo, mas no Banco, os objetos de ouro e de valor, lucrando ainda mais, já que o Banco oferece honestamente um terço do valor e elas nem mesmo um quinto: assim aumentam seus capitais e guardam os objetos de forma segura. 
Mas por que - o senhor se pergunta - a pobre gente não se dirige aos dois Bancos do Espírito Santo e de Donnaregina? Por que se deixa explorar por estas agências? A questão é que nestes Bancos pertencentes ao governo, o trâmite é muito demorado - e muita gente não tem paciência, não sabe como proceder, deseja acelerar o processo, sente-se tomada por uma urgente necessidade e prefere entrar em uma das primeiras agências que encontra, onde é prontamente atendido, sem formalidade e sem palavras; além disso, nesses Bancos a publicidade é sempre grande, e uma pessoa tímida morre de vergonha e prefere entrar na penumbra discreta das agências privadas, onde tudo parece ser feito em segredo; além disso, às sextas e sábados, já que o povo napolitano deve jogar na loteria, ou já jogou, a multidão é tão grande que os Bancos governamentais não são suficientes e as pessoas dirigem-se às agências particulares.

Agora, faça as contas. Em cada beco há uma dona Carmela, em cada rua uma dona Raffaela, em cada praça uma agência autorizada; e em algumas ruas escuras, entre outros negócios, uma agência de penhor. Faça as contas, multiplique, pense na miséria, pense na loteria: de um lado a ganância e a astúcia: de outro a honestidade e a ingenuidade, a necessidade, a miséria. Por causa desse câncer, a usura, agoniza em uma infelicidade infinita o povo napolitano.

\section{VIII}

\section{O PITORESCO}

Pela manhã, se tiver o sono leve, entre os muitos ruídos napolitanos, o senhor ouvirá um toque de sinos em cadência, que ora silencia e ora recomeça após um breve intervalo, misturado a um abrir e fechar de portas, janelas e balcões, conversas, discussões em voz alta, nas ruas ou através das janelas. São as vacas que circulam por algumas horas puxadas por um vaqueiro sujo, através de uma corda: as criadas compram os dois soldos de leite, demorando-se na soleira da porta, brigando por causa da quantidade; muitas, para não ter o trabalho de descer e subir as escadas, amarram à janela uma cestinha com um copo e um soldo, e de lá de cima reclamam que é pouco e que o vaqueiro é um ladrão. Em seguida, recolhem a cestinha com muito cuidado para não derrubar o leite e batem a janela raivosamente. 
As vacas param diante de cada porta, nesse giro matinal: onde as criadas ainda dormem, o vaqueiro grita forte, acalate o panaro $^{52}$; se não ouvem, bate com força o sino da vaca. É uma cena pitoresca, matinal; aquelas vacas cheias de barro aquele vaqueiro de mãos imundas que sujam o copo, aquelas criadas descabeladas e seminuas, aquelas comadres com a camisa manchada de tomate.

A continuação do quadro continua à tarde; das quatro às seis, um toque de sinos agudo e contínuo: são as cabras que passam por todas as ruas da cidade, cada rebanho guiado por um pastor, com um cajado.

Diante de cada portão o rebanho para, deita-se no chão, para repousar, o pastor agarra e arrasta uma das cabras para dentro do portão para ordenhá-la diante da criada que desceu; algumas vezes a patroa é desconfiada, não acredita na honestidade do pastor nem da criada; nesse caso ambos sobem ao terceiro andar, e no patamar de entrada é formado um conselho de família, para vigiar a ordenha do leite.

O pastor e a sua cabra descem, galopando, esbarrando contra algum infeliz que sobe e não espera esse encontro: mais embaixo, já na porta, o pastor se esforça para que suas cabras se mexam, até o momento em que estas começam uma corrida desenfreada, que atinge o ápice ao entardecer, quando elas pressentem que é hora de retornar às colinas.

Em todas as cidades civilizadas, estes rebanhos de bestas, úteis porém sujas e fedorentas, estas vacas não são vistas pelas ruas: o leite é comprado nos estabelecimentos limpos e brancos de mármore.

Em Nápoles, não: é muito pitoresco o costume, para ser abolido. Nenhum município ousa fazê-lo. A grande reforma, em vinte e cinco anos, impediu que circulassem os porcos pela cidade, como antes era permitido.

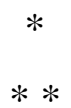

Outra coisa muito pitoresca é a tomada das ruas pelos donos de pequenos estabelecimentos ou dos vendedores ambulantes. Que cenas de cores vivas, vibrantes, luminosas, que bela e grande festa para os olhos, que descrição potente e carnosa, poderiam inspirar um dos modernos experimentais, tão preocupados com o ambiente! Pela rua Roma, a mais importante da cidade, o trecho que vai de São Nicolau da

\footnotetext{
52 Dialeto napolitano: desçam a cesta.
} 
Caridade, até a Chianche della Carità, isto é, duas praças, dois longos calçadões, até as oito da manhã, permanece entregue aos vendedores de frutas, hortaliças e legumes: um contraste de figos e favas, uva, chicória, tomates e pimentões; jogam água e atiram as coisas molhadas; após as oito, é um campo de batalha de águas fedorentas, de cascas, de folhas de couve, de frutas podres, de tomates estragados. Como a mão fatal de lady Macbeth, que nem todas as águas do Oceano poderiam lavar, esse trecho da rua Roma, apesar do cuidado dos lixeiros, nunca chega a ser completamente limpo.

Enquanto isso, muito próximo dali, o grande mercado de Monteoliveto fica quase vazio, com a melancolia das grandes construções inúteis; o de São Pascoal em Chiaia chega a ficar fechado; o vendedor napolitano não quer ir para esses locais, quer vender nas ruas.

Todo o bairro de Pignasecca, do largo della Carità, até Ventaglieri, passando por Montesanto, fica obstruído por um mercado contínuo. Existem lojas, mas tudo se vende na rua; as calçadas desapareceram, alguma vez alguém as viu? As massas, as hortaliças, os produtos coloniais, as frutas, os salames e os queijos, tudo, tudo nas ruas, sob o sol, sob as nuvens, sob a chuva; as caixas, a banca, as balanças, as vitrines, tudo, tudo na rua; fazem-se frituras, e até existe uma famosa fritadeira; aqui se vendem melões e até existe um vendedor famoso por sua voz; os burros vão e vêm carregados de frutas; o burro é o patrão tranquilo e poderoso da Pignasecca.

Aqui o romance experimental poderia até aplicar a sua tradicional sinfonia dos odores, já que somos submetidos a músicas inconcebíveis: o óleo frito, o salame estragado, o queijo forte, a pimenta amassada no pilão, o vinagre ácido, o bacalhau ensopado. Em meio à sinfonia da Pignasecca, encontra-se o grande motivo profundo e que perturba; a venda do peixe, especialmente do atum, com o sol a pino, sobre alguns bancos inclinados, de mármore. Pela manhã o atum chega a vinte e seis soldos e o vendedor de peixe grita o preço com orgulho: mas, chega a noite, pelo declínio da hora e da mercadoria, o preço do atum abaixa para vinte e quatro, uma lira, dezoito soldos; quando chega a doze soldos, a grande nota sinfônica do mau cheiro atinge o seu apogeu. A Pignasecca nunca pode estar limpa; nenhum Município jamais ousou considerá-la rua de descarte. O bairro de Sangue de Cristo, mais conhecido como 'o sanghe d'e galline, por respeito ao nome do Redentor, se ri do Município.

De resto, tudo é belíssimo, para o pintor e para o romancista. 
Não há nada de mais pitoresco que a rua de santa Luzia, de exclusiva propriedade dos senhores pescadores e marinheiros, cesteiros e vendedores de ostras; bem como de suas esposas, vendedoras de água sulfurosa, rosquinhas, polvo cozido e pimentão frito; e de seus inúmeros filhos, nus e morenos como bronze.

Naquela rua, a céu aberto, se faz de tudo: o engomado e a conserva do tomate, os penteados das mulheres e a limpeza das pulgas dos gatos, o preparo de comida e o flerte, os jogos de cartas e o jogo da morra ${ }^{53}$. A rua de santa Luzia pertence aos lucianos, que ali vivem à vontade. Os quatro becos sem saída que saem de santa Luzia em direção à colina, são equivalentes às pensões do bairro Mercato, pela imundície: as ruas unem as casas inclinadas e escangalhadas, os varais vão de uma varanda a outra, uma luzinha diante de uma imagem negra da Virgem ilumina apenas o beco, onde se deposita toda a sujeira daquela gente.

Na direção do mar nem se vê a calçada: ela é totalmente ocupada pelos lucianos, para as cestas de palha e para os frascos de água sulfurosa. No verão, aliás, eles até dormem na calçada ou no parapeito e resmungam para quem ousa passar e acordá-los. Próximo às casas, ninguém encosta: por brincadeira, voam talos de espigas e cascas de figos e as cantinas colocam as mesinhas de seus clientes, na rua.

Os lucianos toleram que o bonde passe pela sua rua, mas reclamam frequentemente e com gosto, já que é uma usurpação de seu território: as vendedoras de água sulfurosa mais parecem homens vestidos de mulher, com os tamancos de salto alto, a saia curta amarrada sobre o estômago, as rosinhas de pérolas amarradas com um fio na orelha, para que o lóbulo não se rasgue com o peso. São naturalmente brutas e encrenqueiras: forçam as pessoas a beberem água, brigam entre elas, disputando os clientes. São indomáveis: para poder governá-las, o fiscal do bairro deve ser também um luciano, que as advirta com palavras ásperas.

Uma vez, duas delas espancaram um guarda municipal que pretendia aplicar uma multa: no dia seguinte, no entanto, combinaram para ajudar a mãe idosa do rapaz, enquanto ele estava no hospital.

Mas santa Luzia, toda pitoresca, sempre fica fora das leis da construção civil e da higiene: é um burgo fortificado.

\footnotetext{
${ }^{53}$ Jogo tradicional muito popular na Itália. Consiste em tentar adivinhar a soma dos números mostrados com os dedos pelos jogadores.
} 
Talvez o cólera não tenha feito tantas vítimas pois ali estão o mar e o sol. Mas que mar negro, untuoso! E que putrefação iluminada pelo sol!

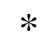

$* *$

É pitoresco, para um amante das cores, ver à noite circulando pela rua Roma, um carrinho montado como se fosse uma mesa, sobre os quais estão distribuídos castelos de figos da Índia, descascados em vários pratinhos: um homem empurra o carrinho, brilha uma lâmpada de petróleo, de vez em quando o carrinho para. Quando parte, deixa atrás de si as cascas espinhosas e escorregadias.

É pitoresco, demais, para um romancista, circular nas ruas após a meia-noite: e encontrar homens que dormem sob o pórtico de são Francisco de Paula, com a cabeça apoiada nas bases das colunas: homens que dormem sobre os bancos dos jardins, na praça Município; meninos e meninas, que dormem nos degraus das igrejas de são Ferdinando, santa Brígida, Nossa Senhora das Graças, especialmente nesta última, que possui uma larga escadaria e alguns amplos terraços, no centro da rua Roma.

Pode agradar a alguns que a poucos metros da rua Roma, se encontre o Claustro de São Tomás de Aquino, onde não há mais monges, mas que é uma pequena vila, uma pequena Corte dos Milagres, com suas vielas, e seus estabelecimentos repletos de sombras, e as casas repletas de pobres e infelizes.

Mas na realidade é muito, muito cruel que tudo isto ainda exista, e que seres humanos estejam submetidos a esta situação, e que homens de coração o suportem.

\section{IX}

\section{A PIEDADE}

Quando uma mulher do povo napolitana não tem filhos, ela não sofre secretamente por sua esterilidade, não faz um tratamento milagroso, como as jovens esposas aristocráticas, não cria um cãozinho ou uma gatinha ou um papagaio, como as moças da burguesia. Em uma manhã de domingo ela se dirige com seu marido à Annunziata, onde estão os enjeitados, e entre as meninas e meninos, bebês ou grandinhos, ela escolhe um com quem mais simpatizou, e, após a declaração ao governador da obra pia, leva consigo, triunfante, a pequena filha da Virgem.

Essa pequena criatura, que não é sua, ela ama como se a tivesse colocado no mundo; ela sofre ao vê-la sofrer, por doença ou miséria, como se fosse do seu próprio 
sangue; na pequena humanidade infantil napolitana, os que mais apanham são certamente os filhos legítimos; ao bater em uma filha de Maria, qualquer pessoa tem um certo escrúpulo; uma certa gentil piedade faz a mãe adotiva exclamar: puverella, non aggio core de la vattere, è figlia della Madonna. ${ }^{54}$ Se esta criatura desabrocha em saúde e em beleza, a mãe dela se orgulha como se fosse sua filha, procura mandá-la à escola ou ao menos a uma costureira para aprender a costurar, já que certamente, por sua beleza, a menina é filha de um príncipe; nem mesmo em caso de miséria ou enfermidade, a mãe adotiva devolve, como poderia, a filha à Annunziata. E o afeto, recíproco, é profundo, como se realmente fosse filial; e a uma certa idade a lembrança da Annunziata desaparece, e esta mãe fictícia ganha de fato uma filha.

E temos outras histórias: uma mãe tem cinco filhos. O mais novo fica gravemente doente, ela faz uma promessa à Virgem para que seu filho se restabeleça; ela adotará uma criança enjeitada. O filho morre; mas a piedosa mãe, levando o lenço negro que é seu luto, cumpre a promessa, chorando. Assim, pouco a pouco, a criança viva e bela consola a mãe da criança morta, e permanece apenas uma doce lembrança e desabrocha uma imensa gratidão pela filha da Virgem.

Em alguns casos, o filho se restabelece: assim que pode sair de casa, a mãe o leva nos braços à igreja da Annunziata, faz com que ele beije o altar, em seguida entram para escolher a irmãzinha ou irmãozinho. E no meio de cinco ou seis filhos legítimos, a pobre enjeitada nunca se sente uma intrusa, nunca se sente ameaçada de ser expulsa, come como os outros comem, trabalha como os outros trabalham, os irmãos a vigiam para que não se apaixone por algum cafajeste, ela se casa e chora copiosamente, quando parte de casa e lá sempre retorna, como se fosse um refúgio e um conforto.

Um caso frequente de piedade é o seguinte: uma mãe muito fraca ou debilitada pelo trabalho dá à luz um bebê, mas não tem leite. Sempre tem uma amiga ou uma vizinha ou alguma desconhecida caridosa, que oferece o seu leite; amamentará dois, que importa? O Senhor pensará em mandar-lhe leite suficiente. Três vezes por dia a mãe,

\footnotetext{
${ }^{54}$ Dialeto napolitano: Pobrezinha, não tenho coragem de bater nela, é filha da Virgem.
} 
com o peito árido, leva seu filho à casa da mãe feliz: e sentada na soleira, observa melancolicamente seu filho que suga a vida. É preciso já ter visto esta cena e entender o tom de voz submissa, humilde, grata, com que ela diz, segurando a criança no colo: $o$ Signore t'o renne, la carità che fai a sto figlio. ${ }^{55} \mathrm{E}$ a mãe de leite acaba afeiçoando-se a esta outra criança e, após o desmame, sofre por não vê-lo mais: e de vez em quando vai reencontrá-lo, leva um soldo de fruta, ou um amuleto da Virgem: o menino tem duas mães.

Este caso também presenciei: uma pobre mulher saía para trabalhar e não podia levar consigo o seu filho; ela o deixava com outra pobre mulher, que engraxava sapatos, e trabalhava em casa, quer dizer, na rua. Ela colocava as duas crianças, a sua e a da sua amiga, no mesmo sportone (berço de vime), amarrava uma cordinha na borda do berço e no próprio pé, e enquanto lustrava os sapatos, cantarolava uma canção de ninar para as duas crianças; enquanto lustrava os sapatos, balançava o pé, para embalar as duas crianças no mesmo sportone. Outra mulher que estava trabalhando, uma amiga cuidava da criança; mas ela vinha de muito longe com aquela criança pesada no colo, suando sob o sol, para que a mãe o amamentasse. A conversa acontecia no patamar ou na cozinha: e ouviam-se estes rápidos diálogos:

- S'è stato cuieto, almeno? ${ }^{56}$

- Cuieto sì, ma tene sempe famme.

- Core de mamma soia!

Quando a amamentação terminava, a amiga pegava a criança que não era sua, dizendo-lhe:

- Iammocene, a' casa, ja'; core de la zia, saluta a mammà. ${ }^{57}$

E ia embora, tranquilamente, sem murmurar, enquanto a mãe, da janelinha da cozinha, olhava mais uma vez para seu filho.

É natural que o povo não consiga fazer caridade de dinheiro, ao mais pobre deles, por não possuir; mas podem ser vistos e ouvidos os mais nobres e extraordinários casos de caridade.

\footnotetext{
${ }^{55}$ Dialeto napolitano: Que o senhor te retribua a caridade que faz a esta criança.

${ }^{56}$ Dialeto napolitano: Ficou quieto pelo menos?

Quieto sim, mas está sempre com fome.

Oh querido da mamãe!

${ }^{57}$ Vamos para casa. Querido da titia, dê tchau para a mamãe.
} 
Uma cozinheira sempre ficava mal-humorada quando a patroa pedia caldo: só ficava feliz quando se fazia macarrão, legumes, risoto, sopas nutrientes e substanciosas. Suspeitou-se por muito tempo de gula, embora para um tipo franzino como ela fosse mais necessário o caldo que o macarrão: na verdade ela dava a sua sopa de legumes todos os dias às duas crianças da porteira, e preferia dar-lhes um prato caprichado do que três colheradas de caldo: ela ficava sem.

Quando vão embora à noite, todas as criadas levam um pacote com as sobras do almoço, quando a patroa tem a bondade de lhes dar: e não é para elas próprias, mas para um irmãozinho, um sobrinho, para a mãe idosa ou para alguma pobre mulher que vive só.

Nenhuma criada come tudo o que lhe dão: três quartos, a metade, às vezes tudo, é destinado a outra pessoa.

E os doentes nos hospitais, os presos, sempre têm uma irmã, uma tia, uma comadre, uma amiga, uma amante que se torturam por uma semana para poder comprar às quintas-feiras ou aos domingos quatro laranjas para aliviar a sede do enfermo ou da enferma, que lavam à noite, apressada e ansiosamente, a camisa do encarcerado, para poder devolvê-la no dia seguinte, lavada e passada.

É preciso ver como ficam as portas dos hospitais, nos dias de visita: e que multidão de mulheres ali se dirige, pálida e ansiosa! Presenciei certa vez uma mulher, cujo marido tinha morrido no hospital, dirigir-se ao diretor, e a todos os médicos dos quais tivesse o endereço, à diretora das freiras, às freiras, aos serventes, e chorar, implorar, e descabelar-se e esconjurar, em nome de Cristo, para que não retalhassem seu marido. A ideia da morte lhe era suportável, mas a autópsia a exasperava.

Na rua, não há mulher que, ao perceber que uma criança a olha, não lhe dê imediatamente o que estiver comendo: e quando não tiver outra coisa, lhe dá o pão. Assim que uma mulher grávida para na rua, todos os que estiverem comendo ou vendendo algo para comer, sem que ela demonstre algum desejo, lhe dão um pouco, obrigam-na a aceitar, não querem ficar com remorso.

E os pobres que circulam, são ajudados da melhor forma possível, por aquela gente pobre: alguns dão um pedaço de pão, outros dão dois ou três tomates, ou uma cebola, um pouco de óleo, dois figos, um pedaço de carvão aceso: uma mulher, para 
fazer caridade de qualquer modo, permitia que uma mendiga viesse cozinhar no próprio fogo, na lareira de tufo, os poucos alimentos que a mulher havia recolhido. Afinal aquele resto de fogo não teria uso após o preparo de sua refeição; era melhor usá-lo para ajudar uma miserável.

Outra fazia uma caridade mais engenhosa: sendo pobre, comia macarrão cozido na água e cozido só com um pouco de queijo picante, mas sua vizinha, muito mais pobre, tinha apenas tocos de pão seco, duro.

Então aquela que tinha um pouco mais de condições dava à vizinha a água na qual havia cozinhado o macarrão, uma água esbranquiçada que ela misturava aos tocos de pão, que amoleciam e tinham ao menos um leve sabor de macarrão.

Uma jovem costureira havia passado pelo Jesus e Maria, o hospital, com uma pneumonia; depois de curada, pálida, exaurida, acabada, recebeu alta. Mesmo assim, o hospital, para evitar uma possível tuberculose, concedia-lhe, todas as manhãs, quatro dedos de óleo de fígado de bacalhau, que ela ia buscar, lá em cima. Ela assim o fez, todas as manhãs, com seu copo, até que recuperou completamente a saúde: Disseramlhe então que não mais lhe dariam o remédio. Ela confundiu-se, empalideceu, chorou, implorou à freira que por caridade não lhe negassem aquele óleo - e depois se soube que daquele óleo, ela se privava para dá-lo de esmola a uma pobre mulher - a qual por miséria, e vencido o natural desgosto, utilizava para passar no pão ou para fritar um soldo de pimentão.

\section{$*$
$* *$}

De outro fato me recordo. Um dia, no largo Consiglio, uma mulher grávida, tomada pelas dores do parto, caiu nos degraus e deu à luz na rua. $\mathrm{O}$ tumulto foi grande: ela ficou calada, mas por piedade, por comoção, muitas outras mulheres berravam e choravam. E em pouco tempo, de todos os bassi, de todos os estabelecimentos, de todos os cubículos, chegaram camisas e faixas para envolver a pobre criancinha, e lençóis para a pobre parturiente. Uma mãe ofereceu o berço de seu bebê morto; outra batizou o menino, fazendo o sinal da cruz sobre o rostinho; outra fez uma coleta por todas as casas da vizinhança; uma quarta, criada, ofereceu-se e foi fazer o serviço doméstico para a pobre mulher. A esposa do padeiro dividiu a sua cama, com a parturiente: e seu marido dormiu sobre uma mesa por dez dias, tendo um saco como travesseiro. E aquela miserável chorava de emoção, sempre que beijava seu filho. 


\section{O VENTRE DE NÁPOLES (AGORA)}

\section{O BIOMBO}

A impressão que se tinha, entrando em Nápoles, a partir da estação ferroviária, há cerca de vinte anos, era a de chegar a uma cidade pequena, mal cheirosa, suja, repleta de casas de alturas variadas e de todas as cores, caracterizadas pela decadência e pela sujeira. Se, depois disso, passado o antigo Corso Garibaldi, a carruagem do viajante diminuía um pouco o passo, na via Marina, naquela rua eternamente sem calçamento, de buracos profundos, onde se balançava tão terrivelmente, se o viajante deixava a sua maleta sobre o teto móvel, ou depositava no banco o nècèssaire de viagem, na parte da frente, quotidianamente havia um assalto, quando não aconteciam dois ou três com o ágil ladrãozinho que fugia nos becos e ruelas, atrás da Marina. E à impressão estética delusória para o viajante que ainda não tinha chegado ao bairro da Beleza, ou seja em direção à Riviera unia-se uma repulsa moral, da qual não apenas os honestos e sinceros guias Baedeker eram o eco, mas da qual todos os viajantes formavam uma larga e invencível propaganda.

Não há nenhuma dúvida de que, após vinte anos, a impressão estética mudou completamente. A piazza della Stazione, atualmente, possui uma vastidão digna de uma metrópole e as três amplas ruas que aparecem diante do viajante, as duas enormes artérias à direita e à esquerda, os grandes edifícios que formam os ângulos da rua, todas estas coisas grandes, repletas de luz, a céu aberto, todas estas coisas que possuem aspecto nítido ou quase, oferecem aos olhos curiosos uma primeira visão agradável. Em seguida, ao entrar, na nova avenida ${ }^{58}$, os olhos um pouco distraídos, um pouco cansados do viajante, passando rapidamente, acabam encontrando um sentido de admiração, para a largura desta rua, para o seu desenho que, até certo ponto é belo. Faltam, é verdade as árvores, que formam a poesia de todos os países civilizados do mundo, mesmo excluindo Paris onde as árvores são a delícia e a admiração dos cidadãos: faltam as árvores e em seu lugar foram colocadas para nosso desprezo, algumas plantinhas tísicas, mal plantadas, não cultivadas, desprotegidas e, vice-versa, execradas, odiadas, perseguidas pelas próprias autoridades, pelos cidadãos e pelas crianças de rua: tanto que seria melhor arrancá-las, ao invés de assistir à lenta agonia da qual ninguém tem

\footnotetext{
${ }^{58}$ Rettifilo no original. Refere-se ao Corso Umberto I.
} 
piedade, nem o prefeito, nem o responsável pelos jardins, nem os proprietários das casas ou das lojas, exceto a vã piedade de algum melancólico passante, que lembra das árvores, não de Paris, pelo amor de Deus, mas aquelas de Milão e de Turim, cidades às quais o Senhor não deu a paisagem mas às quais, os homens, apressaram-se em dar o verde e a sombra das belas árvores, repouso dos olhos, sonho vago da alma. Basta! A nova avenida possui uma linha majestosa, especialmente se atravessamos o seu conjunto rapidamente, olhando sem muito analisar, não nos damos conta das variadas feiúras dos inúmeros edifícios novos que surgiram, de suas cores diversas, alguns exagerados, das grosseiras e pretensiosas ornamentações de alguns deles: este é, entretanto um mal comum a tantas outras belas cidades italianas, onde ao lado dos esplendores antigos e das grandes elegâncias do bom gosto, os arquitetos modernos ergueram os monumentos que demonstram completa ignorância e total ausência de senso estético. Quando foram destruídas as maravilhosas ruelas arborizadas da encantadora vila Ludovisia, em Roma, quando o bosque sagrado dedicado à beleza e à graça, desapareceu, para dar lugar aos bairros Ludovisii, podemos até suportar em paz os exageros de alguns edifícios da nova avenida; mesmo porque alguns deles são até simples, já que felizmente o arquiteto não tinha fantasia; e outros possuem até linhas elegantes. Não é necessário olhar com atenção, isso é tudo, basta dar uma rápida olhada, e assim a vivacidade da grande fonte, na piazza della Borsa, ocultará o desnível famoso e incorrigível de via Guglielmo Sanfelice, enquanto o imponente edifício da Bolsa fará o viajante acreditar, talvez algum mirabolante giro de negócios e a fiação aérea telefônica, em uma rede de assinantes que inclua toda a cidade. Por sorte, os guias omitem estes detalhes; o viajante vê apenas a parte externa; e a entrada em cena da nova avenida, satisfatória de certa forma, garante o seu efeito. Se algum napolitano, ou algum companheiro de viagem mais esperto, conta ao turista que a avenida dividiu em dois o ventre de Nápoles, cruzando os quatro bairros populares e mais populosos de Mercato, Vicaria, Pendino e Porto; e que esta avenida não foi feita apenas para chegar melhor e mais rapidamente à estação ferroviária; nem para os grandes industriais que vendem tecidos de lã e de algodão, nem para ter uma larguíssima avenida, mas em nome de um critério absoluto de higiene e de civilização, sua impressão começa a melhorar. A avenida tinha a função, ou deveria ter, de levar saúde, ar e limpeza a milhares e milhares de cidadãos napolitanos: o seu objetivo, ao concretizar um ideal de caridade civil desejado por Umberto Primo, Agostino Depretis e Nicola Amore, era vencer a doença e a morte, no povo napolitano. Dessa forma, para quem tem a alma sensível esta rua 
assume um significado especial, é o símbolo da solidariedade humana que, do alto do trono, do governo do Estado, do governo da Cidade, sente a necessidade de elevar física e moralmente o povo, dando a eles os bens essenciais da vida, da luz, o ar, a limpeza, a salubridade, dando-lhes a rua e a casa, dando-lhes o modo de adquirir a saúde do corpo que é a alegria da alma, salvando-os das enfermidades, das degenerações, da epidemia, e salvando-os assim da desonestidade e do vício. Esta, na mente de quem a concebeu, depois da tragédia de 1884, depois da visita feita pelo Rei aos casebres e aos barracos, e o horror causado no ânimo dos governantes, esta era a função da Avenida, que se chamou e se chama Revitalização, com todo o seu projeto de ramificações, de aterros, de travessas. A Avenida devia salvar o povo napolitano: e como os olhos que observam de forma fugaz, os lábios que perguntam, nem sempre recebem a resposta de lábios que conhecem a verdade, como o defeito do qual todos nós padecemos é a pressa, como também padecemos de superficialidade, como ninguém tem tempo de fazer aquilo de que gostaria, no mundo, como ninguém possui a vontade necessária para concretizar tudo o que gostaria, como tudo nos escapa, para sermos profundos, assim, conseguimos acreditar que, de fato, a Avenida tenha dado ao povo napolitano tudo o que lhe faltava, e, sobretudo, conseguem acreditar aqueles que passam aqui um dia ou um mês!

$*$
$* *$

Esta ilusão, porém, não resistiria a uma observação mais apurada. Na segunda, na terceira, na décima vez que se atravessa esta magnífica avenida, dirigindo o olhar à esquerda ou à direita, o cenário sedutor apresenta bruscas interrupções. Um imponente edifício, avermelhado, pomposo, pavoneia-se com suas cem janelas: ao lado, observa-se um vazio, e um muro baixo mas muito, muito longo, um murinho onde a publicidade alegremente pendura os seus cartazes, por anos e anos, e atrás dele, muito mais atrás, surgem massas de casas imundas, decadentes, miseráveis, de todos os tamanhos, marcadas por todas as chagas da pobreza e do vício. Isto desaparece: outra construção moderna tenta dar uma aparência civilizada, mas, verdade seja dita, se tentamos fixar o olhar, nos lados, nos fundos, e logo mais atrás, a oito ou dez metros, eis mais uma concentração de pardieiros, em cujas janelinhas estão pendurados os trapos mais indecentes, talvez com a mesma poesia do vaso de basilicão e do melão amarrado ao junco. Assim, oito, quinze, vinte vezes, nos dois lados, mas sobretudo, à direita, indo em direção à ferrovia, esta cortina bruscamente rasgada deixa à mostra espetáculos 
repentinamente feios, nauseantes, nojentos: as palavras são fortes, mas é assim, e o senhor tenta recompor os fios do seu sonho de uma rua majestosa e rica, de uma rua nobre e purificante, de uma rua que sirva igualmente à saúde, à prosperidade e à felicidade do povo. Estas constantes aparições, entre as imensas novas construções, daquelas imundas construções antigas, não distantes, próximas, não distantes, mas ao lado, não distantes, mas logo atrás, destruíram completamente a tela de ilusão. Procurem entre as travessas que deviam partir do lado esquerdo, dos bairros mais altos em direção à Avenida, beneficiando a região que começa em santa Maria Nova e continua por Banchi Nuovi, san Giovanni Maggiore, Mezzocannone, Università, até a Annunziata e a Capuana, e encontrarão apenas duas, completas, no meio de vinte, aquelas em torno de Sedile di Porto, e todas as outras estão inacabadas, são pedaços de ruas, de oito ou dez metros, com belos nomes, de alguns de nossos ilustres cidadãos - e até do senhor, Francesco Serao, meu avô! - e nada mais, a não ser, após estes dez metros, uma concentração de antigas casas que não foram derrubadas e que interrompe as comunicações e atrai a atenção. $\mathrm{O}$ senhor procura as mais belas ruas, que deviam ir da avenida em direção ao mar, revitalizando os bairros de Porto, Mercato e Vicaria. Entre vinte ruas, apenas uma está completa. Outras, quatro ou cinco estão como aquelas da esquerda, mal começadas, abandonadas há anos, irregulares, travessas sem saída, onde, ao fundo, mas não muito ao fundo, surge sempre o mesmo espetáculo, de casas velhas, enegrecidas, esverdeadas, acinzentadas, que parecem estar prestes a cair. Depois, não há mais nada. Na verdade, há alguns becos que se espalham em meio a desníveis assustadores, escadinhas íngremes protegidas por corrimãos toscos, em tudo o que está atrás da Avenida, becos sinuosos e escuros, esquinas onde dois ou três becos terminam em uma descida abrupta, formando um desenho bizarro e grotesco, ao lado, sim, ao lado, dos novos edifícios altos e soberbos. E o senhor, chegando ao fim da Avenida, vendo escapar os últimos sinais visíveis da sua ilusão, pergunta-se se não é vítima de uma alucinação, se parte daquilo que vê não é falso, já que o contraste é forte demais, já que nem tudo pode ser verdadeiro, a poucos metros de distância, o decente e o indecente, a limpeza e a sujeira, a pompa e a incurável miséria, o luxo e a pobreza mais abjeta. O que é falso e o que é verdadeiro? Serão o resultado de um pesadelo todas aquelas casas imundas, fétidas, decadentes, onde parece que se multiplicam a aflição e a tristeza, a doença e a desonra, o delito e a morte? Ou serão os espetáculos que os horrorizaram, como homens e como cristãos, há vinte anos, e que se renovam, falsamente na memória, na fantasia, assim como nos momentos de nossa melancolia 
espiritual e de nossa debilidade física? Ou será que a outra parte, isto é, a aparência moderna da Avenida e de seus palácios que deveriam ser esplêndidos, mas que são apenas novos, limpos, sólidos e grandes, é falsa e pertencente a um sonho? Não serão talvez um longo cenário de tela, sobre o qual um hábil cenógrafo pintou em grandes pinceladas, uma série de edifícios majestosos, e mesmo assim, não se sabe como nem porque, a tela possui grandes problemas de continuidade e deixa vislumbrar a escuridão, a imundície das coxias, onde tudo é podre, fedorento e nauseante? Ou não serão de papel machê ou madeira pintada, estas casas, como aquelas que a mão de uma criança extrai, lentamente, de uma caixa e coloca de pé sobre o chão? Será que tudo não passa de um bizarro biombo, à direita e à esquerda da Avenida? Um biombo cujos pedaços não foram bem unidos e que não consegue esconder aquilo que deve esconder?

$$
\begin{aligned}
& * \\
& * *
\end{aligned}
$$

Passem os seus olhos curiosos das coisas às pessoas da Avenida para conhecer melhor e mais rapidamente o centro do enigma. A influente artéria napolitana pulsa, a toda hora, com sangue vívido: uma multidão atravessa constantemente a Avenida, a pé, de carroça, bonde, especialmente até a praça Depretis, indo e vindo pelos dois lados da via Duomo. Uma multidão de todo tipo e, às vezes, de pessoas distintas, bem vestidas, os homens com a corrente de ouro no ventre, as mulheres com pingentes de ouro no peito. Todo este mundo vai, vem, retorna, afasta-se, um mundo variado, multiforme, multifacetado. Se o senhor tem o hábito de distinguir os rostos e as expressões, no meio da multidão, se possui o ardente e doloroso segredo da intuição, perceberá, ao longo da Avenida, pessoas e rostos que lhe causarão um sentimento de surpresa e, talvez, de pavor. Nas esquinas daqueles becos, próximos aos parapeitos, naquele fatídico limite entre o velho e o novo, e, até, nas poucas ruas principais e não terminadas, sempre permanecem homens, em cujos rostos está impressa a delinquência e cuja expressão não engana; encontram-se mendigos de ambos os sexos e de todas as idades, mas de uma mendicância descarada e repugnante. Além disso, durante a tarde e a noite, exceto pela manhã, estão presentes as desventuradas e desgraçadas mulheres do povo que exercem a profissão mais atroz e digna de compaixão. As calçadas da imponente avenida são, portanto, ocupadas pelo vício, pela miséria e pelo crime. As inúmeras pessoas que passam não olham bem, não percebem: mas duas ou três vezes por dia, um ladrão ataca um cavalheiro ou uma senhora, em plena luz do dia, em plena Avenida, entre centenas de pessoas, e lhe arranca o relógio ou os brincos. A vítima grita, o ladrão enfia-se em 
uma ruela, corre para um beco, desaparece, a multidão faz barulho, não há guardas, os mendigos gritam e uma daquelas mulheres que vivem de pecado dá uma falsa indicação, talvez porque seja amante, amiga ou irmã do ladrão, sempre uma cúmplice. Se a vítima estiver a pé ou de carroça, o ladrão acaba sempre aplicando seu golpe, sem ser preso, evaporando como uma nuvem, no meio de uma daquelas ruazinhas: e muitas dessas ruas possuem a sua própria fama, como aquela logo no início da Avenida, a rua de santa Cândida. Após as nove da noite, o trecho da Avenida que começa na praça Depretis até a Ferrovia, é percorrido por pouca gente: e apesar das grandes lâmpadas elétricas, aquele trecho é um dos mais perigosos da cidade, e mesmo os cocheiros de aluguel apertam o passo claudicante de seus pobres cavalos, indo ou voltando da estação, pois sabem que o seu passageiro sofrerá, quase certamente, uma agressão. A essa hora por lá circulam apenas ladrõezinhos, camorristas, condenados e mulheres de vida fácil. $\mathrm{Na}$ magnífica rua: na rua da saúde e da redenção do povo napolitano!

Ah, este é, portanto, simplesmente um biombo, porém leve, frágil e grosseiro, um biombo que não esconde nem mesmo a quem deseja saber tudo, tudo o que estiver por trás, que for horrível e digno de piedade! E outra vez eu lhes direi o que vi, ali atrás, com uma triste e longa curiosidade, com uma coragem desesperada e, com a angústia mais opressora, do meu humilde porém fiel coração de napolitana!

\section{ATRÁS DO BIOMBO}

Comecemos com o que existe atrás do biombo à esquerda da Avenida, vindo do centro da cidade e indo em direção à ferrovia: observemos se foi revitalizado, como era a ideia simples e nobre de todos aqueles que desejavam salvar o povo napolitano da sujeira, do vício, da epidemia e da morte. Este lado é o menos horrível, quando é percorrido, passo a passo, desde a rua Guglielmo Sanfelice, dos fundos do esplêndido e deserto palácio della Borsa até lá embaixo, na Annunziata. Entretanto! Caminhando por trás do biombo, subindo, descendo, com exceção de duas ou três travessas concluídas, duas pela metade, as outras estão simplesmente abertas, e algumas não foram nem mesmo projetadas, e permanecem os becos antigos, úmidos, altos, escuros e sujos, sobretudo em direção à Universidade. É o lado menos assustador à visão, menos 
nauseante ao olfato, aquele da esquerda; E mesmo assim permaneceram intactas os escuros e perigosos degraus de Santa Maria Nova, os antigos degraus que conduziam ao Cerriglio e que agora conduzem à praça da Bolsa; intactos os estreitos, negros, sufocados, sufocantes degraus de Santa Bárbara, com aquele beco que deverá ter duzentos anos e que vinte anos de revitalização urbanística, a dois passos dali não destruíram, os famosos degraus de santa Bárbara, célebres por seu tarallaro, o popular vendedor de biscoitos, mas igualmente célebre pelo vício diurno e noturno, presentes nos seus antros mais baixos e mais tristes: aparentemente nada disso mudou. Vi com meus próprios olhos, durante esta longa investigação, as mulheres encostadas nas esquinas destes becos, com as saias amarradas sobre o estômago, as sandálias de salto alto, as meias vermelhas e as faces carregadas de maquiagem, e nos olhos um misto de alegria e tristeza mortais, marca característica do pecado e do vício nas mulheres do povo napolitano. Este é o melhor lado que há por trás do biombo, as ruas que sobem, vão em direção aos bairros mais burgueses que populares, vão em direção aos bairros de comerciantes, de profissionais, e o espetáculo não desperta uma repugnância muito profunda; entretanto! Será que não tocaram sequer uma pedra daquela tripa negra, torta, íngreme, escorregadia, que é o beco de Mezzocannone? Ah, este não foi tocado, e todas as pessoas de imaginação, mas sem coração, todos aqueles que amam a cor ao invés da civilização e da decência, todos aqueles que amam o caráter e não têm compaixão de quem morre, fique tranquilo, porque o beco de Mezzocannone foi respeitado e, provavelmente, nunca será tocado! Ali está ele, escuro, fétido, perigoso para as pernas, perigoso para as saias ou meias limpas, ali está ele com as suas casas sem ar e sem sol, com seus negócios que parecem subterrâneos, onde trabalham tintureiros, vendedores de vinho e, até trabalhando na rua, bordadeiras de objetos religiosos, bordadeiras em seda e em ouro: ali está ele, com seu deselegante rei de Mezzocannone, sobre uma velha fonte, com o outro precipício que o atravessa, os degraus de são João Maior: ali está ele, o nosso verdadeiro beco de Mezzocannone, ele não foi tocado e podemos ainda, tapando o nariz, atravessá-lo às pressas: a Revitalização não ousou chegar até ali: não chegará nunca!

Diante da Avenida está sendo construída a fachada da nova Universidade, nem parece tão bonita, ao contrário da antiga Universidade, que tinha a sua grandeza e seu fascínio: quanto estiver terminada, os estudantes, os professores e a ciência estarão alojados de forma magnífica. E a rua são Marcelino? E os outros intestinos de becos que descem, naquela região, intestinos onde se agitam e vivem pessoas, existem homens, 
cristãos, amontoados, e todas as outras ruelas, adjacentes à Avenida? Tudo isso que era a verdadeira revitalização, por que, por que não foi revitalizado, enquanto quase todo o dinheiro, foi gasto, e o pouco que resta, economizado com dificuldade, mal será suficiente para completar as duas alas do biombo, à direita e à esquerda, e nada poderá ser feito por tudo o que está atrás? Nada é mais desejado do que uma bela aparência da nossa querida cidade e nós adoramos que exista um majestoso palácio da Bolsa, mesmo que ali não se façam negócios; adoramos ver a grande gaiola aérea dos telefones, no alto do palácio, na praça, embora sejam poucos os assinantes em uma cidade de seiscentas mil pessoas; adoramos pensar em uma novíssima Universidade, com seus laboratórios e gabinetes científicos, ocupada pela parcela mais genial e simpática da nossa população, isto é os estudantes: sim! Mas que, logo ao lado, a poucos passos, viva na imundície, na miséria, nos casebres, nas cavernas, uma outra parte do povo, para a qual se fez a reforma urbanística e higiênica, que esta parte do povo à qual se destinaram cem milhões, morra de todas as infecções, após ter vivido, bem atrás desses novos palácios: isto é que faz nosso coração tremer de dor e de ressentimento e nos faz parecer uma zombeteira ironia a imponência externa dos novos edifícios, atrás dos quais estão a podridão e a gangrena!

Mas a verdadeira via crucis para o observador que tiver uma alma piedosa, é percorrer, a pé, onde e como puder, tudo o que estiver escondido pelo biombo, à direita da Avenida, vindo do centro da cidade, andando em direção à ferrovia, a partir da parte de trás da rua Niccola Amore, continuando até a piazza Mercato, até a porta Nolana. Na parte de trás? A rua Niccola Amore, à direita, possui apenas um longo e baixo murinho e todas as antiquíssimas casas, por onde se entrava na via Porto, estão de pé, altas, prepotentes, ameaçadoras, há anos desafiando a picareta, que não as toca, que não as tocará, talvez, jamais! Ali, não há nem mesmo o biombo: ali dominam, como espectros da miséria e da ignomínia, todas as casas de Basso Porto refúgios de uma inaudita pobreza, refúgios de crimes e criminosos, refúgios de todas as coisas e pessoas infames e infelizes. Olhem! Devem apenas olhar à sua direita, passando, e o Basso Porto lhes mostrará que foi em vão, sem sentido, inútil tudo o que se desejou fazer e o que não foi feito, que não se quis fazer! Mas se tiverem uma lúgubre curiosidade, desçam até lá. Digo bem: desçam todo o lado direito da Avenida: os aterros tornaram-se um projeto 
fantasioso, nunca executado onde, lá se penetra por todos os modos mais rudimentares, mais incertos, mais traiçoeiros e mais perigosos. Escadinhas de madeira improvisadas e que se tornaram, oh meu Deus, definitivas; escadinhas de pedra, com degraus mal construídos e que tremem a cada pisada; escadas moldadas na terra, sim, na terra, como em qualquer povoado africano; rampas com degraus; rampas de terra, descidas íngremes e escorregadias: todo tipo de precipício, a dois passos dos grandes edifícios. De vez em quando, algum corrimão tosco; apoiando-se neles, olhando lá embaixo, temos a impressão de ver um porão ou um poço.

Os barrancos dão medo. Os aterros deveriam chegar aos primeiros andares destas espeluncas: e no térreo, nos primeiros andares destas espeluncas, essas pessoas têm negócios, vivem e morrem; e assim será, por muitos anos, assim será, talvez, para sempre! O barranco assustador prossegue no Porto, em Vicaria, em Mercato, até o fim, e no fundo desses poços, no fundo desses porões, no fundo desses subterrâneos existe tudo aquilo que existia antes mas, infelizmente, piorado! Os antigos ofícios, os Ourives, os Armeiros, os Fabricantes de Lanças, os Fabricantes de Tafetá, estão lá, com suas pequenas oficinas insalubres, escuras, miseráveis; ainda estão lá as ruazinhas apertadas, entre as casas, os antigos portõezinhos com setenta e cinco centímetros de largura, as antigas janelas de vidros sujos, as antigas pontes sobre as quais parece que se atiram as velhas casas que estão para desmoronar, os antigos becos sem saída, depósito de todo tipo de sujeira: tudo, tudo ficou como era, tão imundo que chega a dar nojo, sem que apareça um varredor para limpar ou um guarda para vigiar.

Tudo se faz nas pracinhas, nos becos: todos vendem ervas, frutas, carne, peixe, em meio à lama constante das ruas; há também as antigas tabernas, onde vendem-se a sopa de feijão e macarrão, as frituras de todo tipo de coisa, de panzarotti a pimentão, as saladas de scapece, o zoffritto cujas porções custam três soldos, dois soldos, até mesmo um soldo! Como antigamente! Pior do que antigamente! A dez passos da Avenida, caldeirões de batatas, caldeirões de polvo, caldeirões de espigas cozidas, caldeirões de castanhas, e que odor acre, ao redor, destas cozinhas, dos pequenos fornos dos Ourives, e dos armeiros, dos caldeirões dos tintureiros! Repleto de cores? Sim: mas horrível! Quero salientar três pontos, entre outros. Uma pequena zona chamada Tentella: ou seja um emaranhado quase verminoso de becos e bequinhos, escuros, que nunca são alcançados pela luz do sol, onde acumula-se há anos, onde há montes de lixo em cada esquina, onde tudo é escuro e imundo, onde, em uma encruzilhada, há uma taberneira com uma farta cabeleira negra, em uma encruzilhada, onde, na penumbra ainda se vê a 
vila Tentella, uma taberneira que vende todo tipo de comida em grandes pratos de cobre brilhante, de fragaglia frita à spiritosa de pastinaca. E me encoraja a ir na direção da vila Tentella, a taberneira, com a cordialidade napolitana, me encoraja pois vê que eu vacilo, diante de todas aquelas sujeiras, ao longo daqueles muros repletos de umidade e odores nauseantes: me encoraja, enquanto eu hesito, fixando os olhos naquela escuridão - e estamos no país da cor azul, do sol! - enquanto em seu rosto amarelo, em seus lábios arroxeados, em seus dentes negros, eu leio todos os vestígios daquela vida mergulhada no fedor e nos contatos constantemente insalubres, três ou quatro pessoas, em um cômodo, e que cômodo, e as horas do dia, em uma cozinha cheia de fumaça, preparando pratos mal cheirosos para vender! Há quantos anos não vem aqui um prefeito ou um assessor? Há quantos anos não são lavadas estas ruas? Há quantos meses não são varridas? Todo a imundície dos animais e das pessoas e das casas, está todo aqui e ninguém tira, à margem dessa nova civilização, atrás dos suntuosos palácios - vá lá embaixo, procurem o beco Barre: deveria ser um aterro que não foi feito, é uma travessa que nunca se abriu. É um beco muito estreito, longo, com casas altíssimas, repleto de balcões, de janelas: os dois lados estão ligados por pontes, de pedras ou de madeira, o que também aumenta a sua escuridão: os dois lados também são ligados por cordas e varais nos quais estão pendurados panos, de todas as cores, remendados, desbotados: e este longuíssimo beco Barre, cujos portões parecem cavernas, não tem um lampião: é um verdadeiro esconderijo de tudo o que existe de mais ignóbil: e é perigoso de ser atravessado mesmo durante o dia, habitado por mulheres de vida fácil, camorristas, ladrões, e o horror que o senhor sentirá não será apenas físico, mas um daqueles aviltamentos morais provocados pelas profundas tristezas. E se deseja escrever um capítulo de um romance popular, mais adiante, muito mais adiante deste tremendo beco Barre, atravessem o beco dos Cangiani, com seu relativo pórtico. Está repleto de ambos os lados de pequenas pousadas, onde se paga quatro ou cinco soldos para dormir, onde dormem quatro ou cinco pessoas no mesmo quarto: estas pousadas possuem uma clientela especial: os carroceiros da Calábria, da Basilicata, do Cilento, da Terra do Trabalho, aqueles que o povo chama de vaticais, por causa do viático, certamente: e estes camponeses estão, durante o dia, nas portas dessas pousadas de quatro soldos, vestidos com suas roupas pesadas e de estilo camponês, com seus chapéus de estranho formato, com seus mantos, sentados no chão, sentados em uma pedra, esperando para retomar o caminho. Eu atravessei este beco, parando para olhar aqueles rostos queimados, sem expressão, pacientes diante das fatigas e do incômodo, aqueles lábios 
mudos: passei longos minutos neste beco escuro, sem calçamento, cheio de água suja, cheio de uma lama grudenta, neste beco tão tétrico que parece uma tumba, e, a um certo ponto, senti-me tomada por um delírio de fugir, fugir, para não ver mais, para não ouvir mais, para não ter mais o espetáculo da mais amarga desilusão, no meu coração de napolitana, para não oferecer aos outros esses desconhecidos sofrimentos, que não são consolados por ninguém, já que esta gente vive e morre, lá embaixo, por trás dos soberbos palácios, anônima, esquecida, desdenhada, desprezada!

E, por último, sabem o que aconteceu? O povo, por não poder habitar a nova Avenida, onde os aluguéis são muito caros, por não ter as travessas a sua disposição, não tendo as verdadeiras casas do povo, foi empurrado, empurrado, para trás do biombo! Assim se amontoou muito mais do que antes; dessa forma o Censo poderia dizer que toda a fachada da Avenida é pouco habitada, e tudo o que está atrás, desgraçadamente, é mais habitado do que antes; onde havia oito pessoas, agora há doze; que o espaço diminuiu e o número de pessoas aumentou; que a Avenida, enfim, mais piorou do que facilitou a vida do povo napolitano! Naquele emaranhado que vai do Porto ao Mercado, em Vicaria, aglomera-se uma multidão assustadora; há poucas fontes de água e faltam casas, que devem ser demolidas (?); não há esgotos regulares, não há lampiões, já que o plano viário, é absolutamente desordenado: falta tudo o que é necessário para a sobrevivência. Se uma epidemia, por mais leve que fosse, acontecesse, impossível circunscrevê-la, impossível dominá-la: naqueles bairros provocaria novamente um massacre, como há cerca de vinte anos; e os nossos construtores de nada sabem; e ninguém quer saber. E aquele povo que foi traído, porque não teve aquilo que a nação lhe havia concedido, para redimi-lo do ponto de vista moral e higiênico, aquele povo que foi abandonado, que sabe, que se ri um pouco disso, suspira, um pouco range os dentes, este grande povo que nós devemos amar, que nós amamos, porque vemos como irmão, porque nós também somos povo, porque nós somos como eles e filhos do mesmo Deus de justiça e de clemência, este povo não resiste aos antigos instintos, à necessidade de viver como deseja, à necessidade de vingar-se desta sociedade ingrata e traidora: não resiste à tentação do vício, do mal: e joga: e rouba: e se vende: e fere: e assassina: e noite e dia, por trás do biombo, ou mesmo na Avenida, o crime, o delito, se 
expandem, florescem, eterna injúria, eterno remorso para aqueles que, traidores do Rei, de Agostino Depretis, de Niccola Amore, de Guglielmo Sanfelice, da Nação, comovida de horror e de piedade, não mantiveram a palavra e romperam a promessa, deixando o povo napolitano ansiando, padecendo, definhando, agonizando, na mais profunda ignávia do corpo e da alma.

\section{AS CASAS DO POVO}

Uma utopia muito nobre, caridosa porém falaz, de todos aqueles que desejaram ou desejam salvar o povo napolitano da miséria, do vício, do delito e da morte, é ou foi a doação de casas feitas especialmente para ele. De fato, nada desperta maior compaixão e maior repugnância do que mergulhar nestes bassi onde vive o povo mal, nestes bassi que já são escuros, oprimidos, estreitos tanto nas ruas maiores quanto nos becos, em cem becos, em mil becos tornam-se refúgios subterrâneos, tornam-se antros onde pululam e se agitam as vidas humanas, pequenas, grandes, decrépitas. O basso é um estabelecimento rudimentar, térreo, quase, sem janela, sem privada, com apenas uma porta de saída, tão estreita que, no inverno, deve estar fechada, que, à noite, não pode estar aberta; e assim que chega a primavera, os moradores, se transferem para a rua, para a calçada, vivendo na soleira, ou na rua, ocupando o terreno público, com seus filhos, com seu forninho para passar e para cozinhar, com a sua máquina de costura, ou mesmo com seu banquinho de sapateiro, com seu banquinho de vendedora de castanhas e de espigas cozidas. No basso dormiam - dormem! - três, quatro, até sete pessoas e nas noites de verão, duas ou três sufocam de calor, arrastam um colchãozinho para fora, colocam uma cadeira, ou se jogam sobre a calçada, dormindo ao ar livre. Como não há privadas, as crianças e os adultos escolhem um canto escondido, próximo ou distante, fazendo dele o seu próprio banheiro e, às vezes, as mães levam os meninos e meninas justamente para não serem perturbadas: dessa forma, muitas ruas de Nápoles transformaram-se de fato em banheiro de pai e filho, inevitavelmente, sem que esta barbárie indecente, obscena possa ser erradicada. Eu citarei e me perdoem a insistência brutal mas necessária - a ladeira da Paggeria, as rampas de Brancaccio, e ai de mim, infelizmente, o elegantíssimo parque Margherita, e as refinadas travessas Partenope, onde se vislumbra uma divina paisagem de mar e de céu, também são destinadas a tal 
uso. Mencionei apenas quatro ou cinco ruas, porque pertencem, é triste dizer, aos bairros mais distintos de Nápoles, ou seja de são Ferdinando e Chiaia, já que estes fazem parte do famoso bairro da Beleza, onde mora a nobreza e se alojam os estrangeiros. Dos becos e vielas contaminadas, contaminantes dos bairros populares, não falo; deveria mencionar centenas deles. É imundo; mas é a verdade. Então, cada salvador de Nápoles, todos os salvadores de Nápoles pensaram, disseram: vamos dar ao povo napolitano apartamentos no primeiro andar, no segundo, no terceiro ou no quarto, casas pequenas, limpas, com uma pequena cozinha, com torneiras de água do Serino ${ }^{59}$, com privadas; vamos dar a eles casas onde circule ar, entre a luz do sol, onde haja espaço para trabalhar, beber em abundância, e onde a decência básica, a básica higiene sejam respeitadas. E assim foi feito; e surgiram três ou quatro grandes ou pequenos bairros de casas para o povo, mas com tamanhas imprevidência e ignorância presunçosa, e com cálculos tão errados que estes bairros não serviram a nada, a nada, e surgem, nos subúrbios da cidade, ao lado de santa Luzia, enormes, massiços, feios, já sujos, quase decadentes, e o povo não mora lá!

Citamos o Borgo Marinai, em santa Luzia, um lugar onde deveriam ter sido destruídas, há vinte anos, todas as casas pitorescas e imundas do antigo bairro santa Luzia, casas que, oh ironia, estão sendo derrubadas há apenas um ano, e houve preocupação sobre o lugar onde seriam alojados os pescadores de polvos, as vendedoras de água sulfurosa, aqueles cesteiros, aqueles mergulhadores ou pescadores submarinos, Pensou-se e foi construída, na faixa de terra ao lado esquerdo do Castel dell'Uovo, um grupo de casinhas térreas, à beira mar. Custavam, custam dezoito liras, um pequeno quarto e cozinha, e vinte e sete liras dois quartos e cozinha. Escárnio! Absurdo! Não existe pescador, não existe mergulhador ou barqueiro de santa Luzia que ganhe mais de vinte e cinco ou trinta soldos por dia e querem que ele gaste dezessete soldos, por dia, só com a casa? Não há vendedora de água mineral, de nozes, de fruta estragada, de rosquinhas, de spassatiempo que ganhe, quando ganha, mais de doze ou quinze soldos por dia, se for sozinha, viúva ou abandonada pelo marido, como poderia pagar dezessete, por dia pelo aluguel de casa? Brevemente: como era natural, nenhum luciano,

\footnotetext{
${ }^{59}$ Aqueduto que abastecia a cidade de Nápoles.
} 
nenhuma luciana foi morar no Borgo Marinai. Nenhum, nenhuma! Preferiram, obstinadamente, suas velhas, destruídas e imundas casas que, por dezoito anos, esperaram a picareta, pela qual pagavam nove ou dez liras por mês de aluguel - é TUDO o que pode pagar o povo napolitano NOVE ou DEZ LIRAS por mês! - e nos últimos dois anos, pouco a pouco recuaram, dirigindo-se às mesmas espeluncas, e expulsos pelas demolições, retornaram, retornam à noite para morar nas ruínas, e ficam de joelhos diante dos demolidores, para não serem perseguidos pelos guardas, pelos policiais, e choram, e gritam, fazem escândalo, não querem ir embora, não sabem ir embora, e alguns deles, oh misericórdia, moram, agora, nas grutas sob o monte Echia ${ }^{60}$ que se eleva sobre santa Luzia, e às vezes uma destas grutas desmorona sobre as cabeças, sobre os corpos destes miseráveis lucianos que dormem, e os mata. Ao mesmo tempo, bem na frente, sob o forte do Ovo ${ }^{61}$, as luzes do Borgo Marinai brilham e refletem nas águas do mar. Quem, por acaso, mora ali, quem vive ali? Pintores que escolheram aqueles pequenos quartos para estudo, já que o lugar é pitoresco; algumas de suas modelos; bailarinas ou chanteuses do vizinho cafè chantant do Eldorado, que alugam por um mês, por quinze dias, um pequeno quarto com cozinha; alguma mulherzinha de vida fácil e mísera sorte; e gente simples, mas não do povo. E quanto aos estabelecimentos comerciais, em uma vasta esquina, foram todos transformados em tabernas grandes e pequenas, algumas caríssimas, outras modestas, outras verdadeiras tabernas onde se respira um ar pestilento de cozinhas mais ou menos insalubres, e no pequeno porto caem todos os detritos destas tabernas e isto entristece, aflige, avilta os dois elegantes clubs de canoagem que existem ao lado. De qualquer modo o Borgo Marinai é vívido, alegre, curioso: e, enfim, inútil também para a sua santa finalidade original. Os lucianos foram de outras partes empurrados de barraco em barraco, de ruína em ruína, de gruta em gruta. E depois, quando tudo, tudo tiver sido demolido aonde irão estes orgulhosos mas paupérrimos homens do povo, estas alegres, mas miseráveis mulheres do povo, aonde irão? Só Deus sabe!

As casas populares construídas na Arenaccia, no Bairro Oriental também foram completamente mal sucedidas. $\mathrm{O}$ menor preço de cada um destes quartinhos é vinte e

\footnotetext{
${ }^{60}$ Primeiro núcleo habitado da cidade de Nápoles, cuja história remonta ao século VII a.C.

${ }^{61}$ Castel dell'Ovo.
} 
sete liras por mês; são exigidos dois meses de aluguel antecipados, por regulamento, ou seja, cinquenta e quatro liras, ou um fiador sólido. Aliás, onde é possível encontrar um verdadeiro homem do povo que possa pagar vinte e sete liras por mês, de aluguel? Para arranjar esta soma, um napolitano do povo deve ganhar pelo menos duas liras e cinquenta por dia, ou três: então, cá entre nós, não é mais um homem do povo, é um operário, mas um daqueles de muita sorte, de obra escolhida, digamos assim: um distinto, pertencente à pequena burguesia. Onde, onde encontrar um homem do povo que disponha, eventualmente, na sua vida de cinquenta e quatro liras de uma vez? Onde, onde encontrar um homem do povo que tenha um fiador sólido? Ah ninguém, ninguém se convence que aqui, o nosso povo, vive de soldos e não vive de liras, que desperdiça a sua juventude, a sua saúde e a sua força em sacrifícios irrisoriamente remunerados, e até mesmo feliz, de encontrar este sacrifício; que, por instinto, visto que ninguém pensou em educá-lo, prefere gastar seu dinheiro mais no alimento que na habitação e nas vestimentas e que quando tem vinte soldos, quinze, pelo menos, lhe servem para seu almoço e o resto, para o resto! Vinte e sete liras por mês! Cinquenta e quatro liras de adiantamento! Um fiador sólido! Que ironia insultante! Nas casas do povo, em Arenaccia, no Bairro Oriental vivem portanto, apenas os operários elegantes, digamos assim, e toda a pequena burguesia, simples funcionários, vendedores, contadores, porteiros, escriturários e, até, alguns funcionários do tribunal: moram apenas aqueles cuja renda familiar varia de setenta e cinco a cem liras por mês, uma posição, já muito distinta nesta nossa cidade. Burguesia, pequena burguesia, modesta, inumerável como as estrelas do céu e os grãos de areia da praia, burguesia trabalhadora, honesta, mas, como se vê, muito pobre, por sua condição: burguesia, nada mais que burguesia, nas casas do povo, mas nada de povo, nunca! E tem mais. Muitas vezes, para estes operários de sorte, para estes obscuros burgueses da decente miséria, é impossível pagar vinte e sete liras por mês, porque eles algumas vezes, quer dizer, não algumas vezes, sempre, têm filhos, e algumas vezes, quase sempre, muitos filhos, já que a fertilidade feminina, a reprodução, sobretudo em certas classes, assume proporções demasiado patriarcais, e também terríveis. Então, encontra-se o pior e melhor remédio: duas famílias em uma casa de vinte e sete liras, apertadas, apertadas, três ou quatro ocupando um quarto, com uma pequena cozinha comum e assim, adeus ar, adeus luz, adeus higiene! Frequentemente uma família subloca um quarto a estudantes, a homens sozinhos e a vida é comum e tanto no primeiro, como no segundo caso a aglomeração, os contatos, o viver uns sobre os outros, conduz, novamente, à sujeira, à doença, ao 
vício, à corrupção e à depravação. Nesses novos caravançarais, lá embaixo, lá embaixo, nesses caravançarais todos já deturpados, de aspecto destruído, de manchas de sujeira salientes nos muros, dos vidros embaçados e em cujas janelas, como nos bairros antigos, estão penduradas as roupas desbotadas, mal lavadas, e os maços de tomate e de alho, nesses ridículos caravançarais que deviam servir à regeneração física e moral do povo napolitano, desenrolam-se, diariamente, dramas dolorosos provocados justamente pela pobreza e pela degeneração, desenrolam-se farsas grotescas e se vive mal, muito mal, como se vivia nos outros lugares, e por um povo que, por abnegação, por virtude natural, por honestidade natural conserva a decência dos costumes, existe uma outra que para lá transportou todos os seus instintos indomáveis, indomados, que ninguém procurou domar, que implantou, lá, uma nova vida agitada e mal comportada como nos velhos bairros, que, enfim, se não rouba, não assassina, pois são outros os covis e os esconderijos dos ladrões e dos assassinos, coloca, ao lado do povo burguês e decente, um exemplo da mais baixa burguesia, indecente, rumorosa, mal educada, rude, repugnante. Não é o povo, não povo! O povo napolitano permaneceu nos seus bassi dos velhos bairros, nos seus bassi dos bairros não revitalizados, nos bassi infelizmente, do Vasto, de Arenaccia, do Quartiere Orientale; nunca subiu, em nenhum lugar, da Nápoles antiga, da Nápoles nova, ao primeiro andar ou ao último andar, porque não pode pagar os preços, mesmo os mais baixos, porque quem construiu aquelas casas não sabia nada, ignorava tudo e, mesmo assim, fez uma ótima especulação, já que todas aquelas casas foram alugadas, como disse; mas repito, e sempre repetirei, o povo napolitano não se moveu do seu basso, onde quer que o basso se encontre, seja um galpão mais ou menos limpo ou um buraco escuro e insalubre.

Assim, infelizmente, todas as grandes ideias dos grandes homens, todos os vastos projetos, baseados em milhões, todos os empreendimentos colossais, que aspiravam à revitalização higiênica e moral de Nápoles, é preciso dizer, fizeram fiasco. Então não há remédio? Não há mais nada a fazer? Nada mesmo diante de tantas tristezas, tantos desastres, tantos perigos sociais? Quem sabe! Veremos! 


\section{O QUE FAZER?}

Se leio jornais, opúsculos, livros que se ocupem das grandes questões napolitanas, se eu sigo o movimento das suas associações, se noto os votos dos congressos, se ouço os lamentos dos donos de hotéis, não vejo nada mais que uma constante, nobre, admirável e exclusiva preocupação de tornar sempre mais agradável a estadia dos estrangeiros em Nápoles. Muito bem! Ótimo! Todos os esforços para atrair para cá, além do fascínio de uma indescritível paisagem, além da doçura de um clima muito suave, da civilidade e da graça do ambiente, o grande mundo cosmopolita, que tantas delícias encontra, no inverno, no Cairo e em Nice, todos estes exemplares esforços, feitos não apenas para atrair, mas para mantê-los aqui, entre nós, a riquíssima e elegantíssima sociedade internacional, são dignos do maior e mais profundo encorajamento. Sim, formamos o bairro da Beleza onde, na beira do mar, desde o primeiro ângulo de Santa Luzia Nova até Mergellina vêem-se apenas belas casas, jardins floridos, magníficos hotéis, lojas de artigos de arte: façamos com que estas ruas sejam bem varridas, duas ou três vezes ao dia, e que a pavimentação não represente um perigo para os ossos dos estrangeiros: imaginemos que as carruagens estejam menos sucateadas, os cocheiros menos esfarrapados e menos sujos e, sobretudo, menos ávidos e mal educados com os estrangeiros: realizemos o milagre de fazer desaparecer os mendigos nojentos, os vendedores ambulantes detestáveis, os floristas petulantes e tantos outros indivíduos muito mais baixos, até mais suspeitos deste bairro da Beleza: e que os capitalistas construam um kursaal em santa Luzia, aberto no inverno para os estrangeiros e no verão para os provincianos: e outros capitalistas façam un Palais de la jeteè na rotatória de via Caracciolo, belo e rico como o de Nice: e haja outras atrações maiores e mais fortes, cujos projetos não conhecemos, fervem na mente daqueles que amam Nápoles: e que tudo isso seja espalhado aos quatro ventos da imprensa dos dois mundos, que a salubridade e a higiene de Nápoles tornaram-se de primeira ordem, o que é verdade, que se espalhe que a sua mortalidade é baixíssima comparada à de tantas outras capitais europeias e de Nice e do Cairo, sobretudo, o que é a santíssima verdade; e que se espalhe, já que ninguém sabe no exterior, que a sua água de Serino é a melhor de todas as águas europeias, como foi declarado em todos os boletins sanitários, com a garantia da análise e que não é necessário, portanto, recorrer, para os estrangeiros, a todas, as águas minerais que bebem em outros lugares, da Saint-Galmier à Apollinaris, e que pedem aqui também, porque ignoram o Serino: e de qualquer maneira, de qualquer 
forma, que dobre, que triplique o movimento dos entrageiros em Nápoles, que torne a estadia deles tão agradável a ponto de mantê-los aqui por dias e semanas, para imprimir no espírito, partindo, uma saudade invencível, de modo que, distantes não podendo retornar, mandem até nós seus parentes, seus amigos, seus conhecidos. Esta é uma obra bela e distinta, mesmo que esteja por demais relacionada com o reclame industrial, mesmo que tenha muito os ares de uma especulação, mesmo que tenda a transformar cada vez mais em um enorme Palace, toda a Nápoles que vai, desde a parte baixa próxima ao mar até as colinas floridas de Posillipo e de Vomero! O que foi feito em Nice e Montecarlo fez a fortuna de toda a Corniche ${ }^{62}$ de Mentone a Hyères, o que foi feito no Cairo, fez a fortuna de todo o Egito: seja, seja, esta obra boa, esta obra santa, e nesta cidade tão bela e tão pobre, tão fascinante e tão cheia de miséria, nesta cidade tão deliciosa e onde se morre de fome, nesta cidade de encanto indizível, que se dê à indústria do estrangeiro a forma ampla, feliz, afortunada, que traga, a Nápoles, o único modo de fazer viver centenas de milhares de pessoas!

Mas que seja permitido a uma alma solitária e ardente de paixão, pelo seu país, como é a minha, de pedir uma parte de tudo isto, uma pobre, pequena parte para melhorar as condições higiênicas e morais do povo napolitano. Não se pedem milhões, já que os milhões fracassaram na obra de Revitalização, e ninguém, naturalmente, quer dar mais milhões, quando os primeiros foram mal gastos ou perdidos, por fatalidade como se uma mão misteriosa perseguisse nosso bom povo.

Pede-se, em nome daquele Deus justo que desejou que fossem acolhidos todos os pobres, no seu nome, pobre e vagabundo ele mesmo, sobre a terra, que à redenção física e espiritual dos pobres um pouco de atenção, um pouco de dinheiro, um pouco de cuidado seja dedicado por aqueles que devem e podem fazer isto! Tudo deve ser feito com modestas mas tenazes ideias de bem, com simples mas obstinados remédios, com humildes mas constantes intenções de ajudar. Distante da retórica social, distante da retórica industrial, distante da retórica administrativa, vinda do Comune, a pior retórica porque estraga o que de prático, de útil, de bom se poderia fazer, pelos nossos. Por que não obrigam a sociedade dos novos bairros em Vasto, em Arenaccia, no Quartiere Orientale, a reduzir ao mínimo possível os aluguéis, de modo que as casas feitas para o

\footnotetext{
${ }^{62}$ No texto de partida Corniche, que em francês significa estrada ao lado de montanha. Neste caso referese a uma das estradas da Côte D’Azur.
} 
povo sejam habitadas justamente por eles e não pela pequena burguesia, de modo que cada quarto não custe mais de nove ou dez liras e não possam morar por regulamento mais de dois ou três pessoas, quando há crianças? Que se tente isto! E se não bastar, em todas as novas construções nos bairros populares ou nos bairros mais aristocráticos, por que não obrigam, com uma lei, com regulamento, a ter um plano de seus edifícios, o último, feito de modo que a gente do povo possa morar, com quartos, tetos, isto que se chama o suppenno que não custem, de fato, mais de nove ou dez liras por mês? E se alguma sociedade, aqui, desejar construir nas colinas, ou na praia, na direção da ferrovia ou do mar, por que não obrigá-la, por lei ou por regulamento, se desejar tal concessão, a construir no quarto ou quinto andar, estes quartos, ao qual se teria acesso pelas escadas de serviço? E nos conventos que o Município agora possui em grande número, de onde foram desalojadas tantas desventuradas freiras porque hospedam apenas grandes eleitores ou servidores de conselheiros comunais? Por que, já que as pobres freirinhas foram colocadas na rua, sujeitas à miséria e à morte, não se faz uma economia, uma santa economia para limpar, restaurar, estes numerosos monastérios e não se alugam, aqueles quartos, tornando-os limpos e saudáveis ao povo napolitano? Um pouco deste dinheiro que deveria servir, para atrair pessoas da Europa e das Américas, pouquíssimo deste dinheiro dedicá-lo, sabiamente, de forma lenta mas constante, para criar simples e modestos quartos não casas, mas, quartos para o povo!

E algum daqueles vívidos lampiões a gás que brilham no Bairro da Beleza, por que não o colocar lá embaixo, até menos brilhante, mas lampião, mas aceso, atrás do biombo, atrás dos famosos palácios da Avenida, onde, à noite, se rouba, se cometem infâmias e se mata, nas trevas profundas e assustadoras? Por que não dar um pouco de luz, só um pouco, para que não se possa mais nem roubar nem matar, ao menos em algumas dessas ruas? Não é um dever estrito, rigoroso, de qualquer município, de dar a luz, à noite, aos cidadãos? Este rigoroso dever, por que não se cumpre, a favor do povo napolitano, dos dois lados da Avenida, do Porto a Pendino, no Mercato e em Vicaria? A ideia é simples: algum lampião, oh construtores nossos! E desta pura, fresca e espumante água de Serino, orgulho de Nápoles, salvação de Nápoles, águas internas, águas externas, porque lá embaixo, atrás do biombo, não há, me parece, nem mesmo o encanamento? Este supremo benefício que tanto custou não era, não deve ser feito 
somente para lavar o rosto e encher a barriga dos ricos, estrangeiros, ou não, burgueses, grandes ou pequenos, mas quem o projetou, este benefício profundo da água, quis sobretudo para o povo e o povo não possui, atrás da Avenida, ou tem pouco ou não tem, e bebe e se lava na água contaminada dos poços e das cisternas: e de qualquer modo, provisório, semi provisório, definitivo, da melhor forma possível, é preciso dar, dar esta boa água aos bairros populares e que não sirva apenas para regar os passeios de via Caracciolo! E algum daqueles varredores que devem deixar límpido como o cristal o bairro da Beleza, depois de ter limpado este bairro, dirija-se aonde nunca esteve, onde nunca se limpa, e retire, tente retirar a sujeira incrustada, e leve embora, hoje superficialmente, amanhã melhor, daqui a um mês completamente, os montes de imundícies antigos e podres. Que haja um pequeno, pequeno serviço de limpeza, lá embaixo, que haja uma vassoura, o carrinho, que se cumpra o dever obscuro mas necessário de limpar as ruas, da melhor forma possível, mas de qualquer modo, todo dia! E algum daqueles gloriosos guardas municipais encarregados de afastar os miseráveis, os mendigos, os floristas, para não incomodar os estrangeiros da Riviera e de Chiatamone, penetre, penetre lá embaixo, e aplique as leis da polícia urbana, lá embaixo onde não há sinal de nada disto, lá embaixo onde cada um faz o que quer, porque ninguém se encarrega de obrigá-los a fazer aquilo que devem! E que os guardas da delegacia não se ocupem apenas em vigiar nos bairros aristocráticos a fim de que os cocheiros não apliquem preços abusivos para os hóspedes do Grand Hotel e do Bertolini, mas que alguns desses guardas se ocupem em impedir, possivelmente, o vício, a infâmia e o crime nos bairros populares, atrás da Avenida!

O que peço eu, enfim, para os meus irmãos do povo napolitano, o que peço eu como todos aqueles que têm coração e alma, além do fim do descaso e do abandono? $\mathrm{O}$ que peço eu, em nome da igualdade humana e cristã, além de o povo de lá debaixo seja tratado como todos os outros cidadãos, tenha uma casa, tenha luz, à noite, água, limpeza, segurança, seja salvaguardado e protegido contra si mesmo e contra os outros? O que peço eu, se não a aplicação da lei humana e social, tratar aqueles como são tratados os outros, dar a eles aquilo que cabe a eles, come seres humanos, como cidadãos de uma grande cidade? Faça o seu dever a todos, nada mais que o seu dever, para o povo napolitano dos quatro grandes bairros, faça o seu dever como se faz em outros lugares, faça com cuidado, com consciência e, a cada dia, lentamente, 
constantemente, será encontrada a solução do grande problema, sem milhões, sem sociedades, sem obras grandiosas, a cada dia haverá melhoras, até que tudo será transformado, milagrosamente, para o espanto de todos. Simplesmente porque aqueles que deviam fazer algo deixaram de ser ausentes, negligentes, inertes e preguiçosos e fizeram aquilo que deviam.

Nápoles, primavera de 1904

\section{III}

\section{A ALMA DE NÁPOLES}

\section{A HONRA}

Melancolicamente sentado à mesa na famosa Osteria della Giarrettiera o grande cavaleiro Falstaff remói a maliciosa e audaz afronta feita pelas alegres comadres de Windsor, que o enfiaram em uma grande cesta, debaixo de uma montanha de roupa suja e o atiraram no Tâmisa. Com uma enorme caneca de vinho quente, ele tenta aquecer seu pobre estômago, gelado pelas águas do rio: com filosóficas meditações, um pouco cínicas e dolorosas, procura revigorar sua alma deprimida. Bebe, Falstaff, um grande trago de seu grog e diz com um sorriso amargo: «A honra? O que é então a honra? Talvez seja uma sobreveste? É um par de botas? Pode-se comer a honra? Ou será que se pode beber a honra? O que fazes com a honra? Pode-se, quem sabe, ganhar dinheiro com a honra? De qual honra falas? Da minha? Da tua? A minha é diferente da tua! A honra? Uma palavra: um sopro, na verdade, nada mais que um sopro.» Curva as suas costas largas, bebe mais um pouco e com a mão quadrada pousando o copo, faz um gesto para afastar a honra, este sopro, de sua vida de ébrio.

Falstaff, aquele que quando jovem havia sido pajem do duque de Norfolk e esbelto a ponto de passar por dentro de um anel, aquele que havia sido amigo de Harry Plantageneta, príncipe herdeiro e depois rei da Inglaterra, Falstaff, agora com cinquenta anos, obeso, calvo, preguiçoso, guloso, comilão, bêbado, dissoluto, pleno de espírito, pleno de recursos, mão leve, trambiqueiro famoso porém simpático, com uma certa elegância, Falstaff, ousa dizer, naquele tempo, todo o seu pensamento sobre a honra. Ele possui todos os vícios, exceto a imundície da hipocrisia; ele pode ser culpado de todos os crimes, menos de fingir virtude: ele vive de todo tipo de negócio sujo, mas declara 
que não pode fazer outra coisa a não ser cometer fraudes e roubos, pois precisa viver, comer, beber, vestir-se, enfim! O grande William é tão sincero, tão humanamente sincero e até brutal nas suas criações de verdade ou de vida! A partir do momento em que, com honra, Falstaff não consegue ter nem uma roupa, nem um par de sapatos, nem uma caneca de claret, nem um ganso recheado, nem um vasto leito onde possa espalhar seu físico colossal, ele declara abertamente que renuncia à honra e que desperdiça este sopro inútil de sua existência. Outros tempos! Quem ousaria dizer isto, agora, com toda a polidez, os refinamentos e os seize reflets da sociedade moderna? Qual cínico entre os mais cínicos homens de negócios modernos, ou qual célebre aventureiro faria a declaração de Falstaff? Quem renegaria a honra, com essa cruel filosofia como fez o ventrudo cavaleiro de ventura inglês? Outros tempos! Tantos, provavelmente, pensam como ele ainda hoje; tantos como Falstaff, no segredo de seu espírito, estão convencidos que não sendo possível ganhar dinheiro, com a honra, e o dinheiro, sendo não apenas útil, mas necessário é melhor renunciar tacitamente a este sopro inútil da honra: tantos, e talvez sejam os menos numerosos mas os mais temíveis, começaram a fazer o glacial e mortal raciocínio de Falstaff, mesmo antes de entrar na luta da vida. Outros tempos! A superfície humana mudou: toda a aparência social é diversa: e Falstaff, gordo ou magro, elegante pajem gentil ou grande capitão de ventura, pode sempre desenvolver os seus instintos, sob qualquer forma das mais altas e das mais baixas, mas ninguém ouvirá nunca dizer que honra é um sopro e que não se faz dinheiro com o vento.

$* *$

Nós, porém, temos uma ideia solitária. Ao contrário do que se agita no fundo das consciências apegadas ao tormento da necessidade, minadas pelo desejo de todo tipo de riqueza e poder, em oposição a este cômodo e fácil cinismo secreto, nós acreditamos que a honra não é uma palavra, não é um sopro inútil e que não é nem belo nem útil fazer um gesto, com a mão, e expulsá-la da própria vida. Nós acreditamos em mais do que isso: ou seja, que, com a honra, seja possível até mesmo ganhar dinheiro. Parecenos impossível acreditar que apenas os desonestos, ou os ladrões consigam enriquecer, na sociedade; acontece, isto é verdade: acontece muito: mas, por outro lado, diante de toda gente de consciência ambígua, de caráter equívoco, de tendências suspeitas, diante de toda gente que faria qualquer coisa, a fim de alcançar tudo, os nossos olhos mortais veem muitas outras que de forma discreta e austera, fazem a sua parte, no mundo, 
criam a sua fortuna e a de outros sem prejuízo da honra. Diante de órgãos financeiros que baseiam sua sorte sobre mil cálculos sutilmente enganadores e dos quais qualquer manifestação econômica representa um marchè de dupes, diante destes grupos que, agora, se fazem sempre mais raros, no mundo, outros vemos surgir, prosperar, entre nós, na Europa, longe, em todo lugar, no qual cada ato é regulado pela honestidade comercial, pela lealdade industrial. Para quem vê o minuto presente, para quem sabe olhar na direção do horizonte, na direção do futuro, pode parecer, talvez, que a honestidade é um mau negócio e que um cavalheiro permanece pobre: assim é: mas não para todos: mas não por muito tempo: mas o cavalheiro ou termina por vencer o seu horrível destino, ou conserva, como um tesouro, a sua perfeita reputação. Com a honra também se ganha dinheiro, graças a Deus! Centenas, milhares nos confortam nesta fé um pouco solitária mas sólida, os exemplos particulares, os exemplos coletivos, no qual a probidade, a integridade, o rigoroso escrúpulo foram a fonte de fortunas individuais e de fortunas sociais verdadeiramente poderosas; em todos os cantos da terra, nos livros, nos jornais, nas crônicas, na vida, florescem estas histórias de prosperidade muitas vezes colossais, baseadas apenas no trabalho, na vontade, no intelecto, mas baseadas, sobretudo, na honestidade pessoal ou coletiva. Era natural ao barrigudo de Windsor, a quem convinha ficar sentado sob a pérgola da taberna, bebendo vinho aromatizado e jogando dados, dizer que a honra não traz os côvados de veludo para fazer uma sobreveste ou não paga a conta da taberna: é cômodo aos ambiciosos modernos pensar entre si que a honra non si transforma em cheques, em palácios de mármore, em guardaroupas deslumbrantes, em galerias de quadros e em coleções de joias. É cômodo: mas é falso. Quem já escreveu, escreve, ou escreverá a história da riqueza, a história dos ricos, diga se não é falso: e quais países, sociedades, homens, mil vezes, cem mil vezes partiram dos mais humildes desejos de bem e de honestidade para chegar aos mais belos ápices da fortuna, sem jamais ter se desviado.

\section{$*$
$* *$}

Que pensem assim, aqueles que, hoje, se reúnem, com certa solenidade, estes deputados de Nápoles, que desejam ardentemente fazer o bem à sua cidade. Pensem: não deixem vacilar um só instante, suas consciências de cavalheiros: não lhes falte em nenhum momento a confiança na probidade humana, sobre a qual se baseia a sua vida e na qual encontrou a sua fórmula. Eles querem, os deputados napolitanos, a prosperidade ampla da encantadora metrópole que, apesar de dotada de todas as belezas, ainda é 
pobre e triste; mas querem a sua prosperidade junto ao alto respeito de sua honra. Seja, seja acima de tudo, a honra: acima de tudo que os escolhidos, para decidir sobre as coisas do Comune e que, escolhidos, serão indicados pelo voto popular, tenham como marca de seus nomes, a transparência de seu caráter: acima de tudo que, diante da Itália, diante da Europa, onde quer que o nome de Nápoles for pronunciado, seja, então, pelo decoro, pela consciência de quem a representa, unido ao da mais bela dignidade civil: acima de tudo que, por convicção, jamais a suspeita, a acusação, a delação possa atingila: acima de tudo que em qualquer lugar, o homem honesto, inteligente, ativo, produtivo, seja o seu trabalho dado a Nápoles, fazendo-lhe o bem com todas as suas forças. Quando isto for organizado, com sapiência, com generosidade, integrando aqueles que deverão ser os futuros administradores, onde quer que se encontrem cavalheiros e homens capazes, sem se preocupar com ultrapassadas questões de partido, de cor, coisa velha, coisa destruída: quando isto for uma missão cumprida, a honra de Nápoles, que lentamente se reconstrói, mas com segurança, esta honra de Nápoles servirá também para ganhar dinheiro. Quando os capitalistas estrangeiros, do norte, souberem que, contra qualquer obstáculo, Nápoles quis para seus magistrados, comunais, os seus melhores cidadãos, quando os homens de negócios de todos os países, de todas as regiões, souberem que, aqui, o sentimento da probidade social foi recuperado, nas pessoas nas coisas e nos costumes: quando os industriais de todo o mundo compreenderem que é possível ter confiança; então, sim, uma pequena ou grande planta da fortuna pública, nascerá, germinará, frutificará neste solo fecundo, nesta terra de belas almas. Tudo se fará, aqui, a partir do momento em que o bom nome napolitano, que, o decoro da sua cidadania, que, toda a sua honra, enfim, for exaltada: tudo será tão fácil, tão simples, tão natural que o mundo se surpreenderá. E na honra, nesta potência completamente moral, neste elemento mais puro e, digamos, mais etéreo da consciência social, Nápoles reencontrará a sua vida, a sua fortuna, a sua riqueza!

\section{O BAIRRO DA BELEZA}

Uma das coisas mais estranhamente falsas, ditas, repetidas e sustentadas, por Nápoles é a profunda miséria da sua Prefeitura, é a falta da lira e do soldo para seguir adiante: uma daquelas lendas bizarras, grotescas e injuriosas que muitos de nossos ilustres e obscuros cidadãos se comprazem, em todos os lugares, de confirmar; com as provas mais singulares e fantásticas. Sabiam? Não há um centavo para abrir uma escola: 
o Município pode a duras penas pagar os seus professores e professoras. Sabiam? Não há mais do que quatro mil liras por ano, para plantar árvores nos jardins públicos e na Vila e, assim, deve conservar, na direção do mar, aquele aspecto de jardim devastado. Sabiam? É impossível tapar os buracos perigosos na pavimentação de rua Chiaia: os senhores devem quebrar o pescoço: os blocos são muito caros, precisa esperar o balanço do próximo ano: então, veremos. Desta passagem, a cada vez que o Município deve arrumar cinquenta centavos, torna a lenda da pobreza à qual foi reduzido, um mendigo que nenhuma instituição pode mais receber: e, sobre estas mentirosas aparências, sobre estas frases feitas, pela qual a multidão se faz comodamente governar, ninguém se dá conta que, no Município, lentamente, de forma invisível, os milhões presentes e futuros, dançam uma quadrilha que, a cada dia, torna-se mais alegre. Quem ousaria afirmar, se tiver olhos e ouvidos, que o Município de Nápoles é pobre, quando colocou em discussão, há um ou dois anos, somas enormes, ora para uma coisa, ora para outra? Quem poderá continuar a dizer isto, quando, pouco a pouco forem examinados todos os projetos que estão em discussão e, que custam muitas centenas de milhares de liras e alguns custam milhões? Quem ainda poderá afirmar que não há dinheiro para as creches, para as escolas, para os jardins, para a limpeza, para a irrigação, quando está diante de nós um monte de castelos de areia, um mais caro do que o outro? Quem poderá dizer que há poucos milionários em Nápoles, para dar um índice mesquinho, exíguo, da nossa riqueza, quando o primeiro milionário é, na verdade, a Prefeitura, e, como todos os milionários, é um pouco inconsequente, pois deixa de gastar algumas centenas de liras, em coisas necessárias e desperdiça, ou se compromete em desperdiçálo, em despesas supérfluas? O Município não é, provavelmente, nem Morgan, nem Carnegie, nem Vanderbilt, nem Rockefeller; a sua fortuna é mais modesta: os seus milhões são em menor número: mas isso nos engana, agora, como um bom pequeno milionário que fuma cigarros de três centavos, mas que possui um haras de cavalos de corrida. Tenho diante dos olhos e espero poder comunicar, sempre que for o caso, um elenco de projetos, de propostas, de coisas feitas pela metade ou a se fazer, onde os gastos, às vezes inúteis, às vezes extravagantes, quase sempre imprudentes, são altíssimos. Eu não sou a tutora da Prefeitura, graças a Deus, e nem você, amigo leitor, para sua sorte: mas algum soldo, destes milhões, é seu e meu. Interessemo-nos por estes poucos centavos, teus, meus, leitor, porque são uma parte destes milhões. 
O Bairro da Beleza! Aqui está um, aqui está ele. O seu nome é eminentemente pretensioso: quando souber bem o que é, este bairro, meu amigo leitor e irmão, irá achálo eminentemente ridículo. Trata-se daquele grande deserto de Santa Luzia nova, onde todos os apaixonado pela velha Nápoles, preferiam, talvez, ver aquele belo mar de Santa Luzia, o antigo, o nosso mar: vamos dar-lhes um suspiro de lamento, em nome do pitoresco, consolemos a desilusão dos estrangeiros e reneguemos a civilização, tacitamente, no nosso espírito. Quando não havia sido inventado o bairro da Beleza, este deserto melancólico, atrozmente triste, em certas horas do dia, ladeado por aquela rua cheia de pó e desigual, devia ser povoado assim, pelo Banco de subvenções genovês: deveriam erguer treze enormes edifícios, treze quartéis, semelhantes aos dois já construídos, aquele onde se encontra o Hôtel Santa Luzia e o segundo está em construção. Não existe nada de mais feio, mal feito e pesado: ruas estreitas entre os edifícios: e completamente perdida, atrás, a subida de Luzia antiga. Quando estes horríveis quartéis forem erguidos, outra prova da falta de educação estética, chegaria para afligir o nosso espírito inquieto: e as abominações retilíneas, das quais fala Edgar Poe, afastariam, com seu horrendo aspecto, a nossa fantasia, amante da beleza, da graça, da leveza. Mas existe um Deus, no céu! Dado o alto preço que o Banco de Subvenções havia colocado para aqueles terrenos há cinco anos, que ainda são mantidos, e como para construir, lá, onde está o mar, embaixo, exige-se o dobro ou triplo do valor, ninguém quis comprar aqueles terrenos, ninguém pensou em erguer um palácio ou palacete e a sociedade nem ousou construir nada. Certamente, a sociedade perdeu e ainda perde muito dinheiro: mas isto não nos interessa. Nós lamentamos por Santa Luzia antiga, as casas de banhos, a água sulfurosa, as vendedoras de água, os vendedores de ostras, as trattorie e os cesteiros! Nós lamentaremos ainda mais, amigo leitor, se por acaso o bairro da Beleza se concretizar. O novo projeto, no qual parece que concorreram Raffaello da Urbino, Michelangelo Buonarroti, Vanvitelli e Dante Gabriele Rossetti, será assim: ao invés de treze quartéis, serão onze e serão divididos por vias um pouco mais largas, com filas de árvores, semelhantes às da Avenida e que, certamente, próximas ao mar, serão destruídas pelas brisas marinhas, como foi dito, já foram destruídas as da Vila. Estes onze edifícios também terão, um pouco de verde ao seu redor, uma pequena faixa, próximo ao mar. E basta. Mas então esta é a ideia original que permitirá que Santa Luzia seja chamado o bairro da Beleza? E o autor do projeto, digamos assim, será comparado a Arnolfo di Lapo ou a Lenôtre, arquiteto de Versalhes? 
Não, senhor. No centro do novo bairro, próximo ao mar, os edifícios se dividirão em semicírculo e deixarão um espaço, no meio, de oito mil metros quadrados - não se iluda, amigo leitor, oito mil metros quadrados não são grande coisa - onde haverá um jardim, e, no centro, parece impossível, uma fonte. Ao redor, ao redor do semicírculo haverá um pórtico, de estilo grecorromano, com apenas um andar, para ser ocupado por cafés, cervejarias, cafè chantant, talvez, sempre em estilo grego. E basta. Este é o bairro da Beleza: nada além disso. Um jardinzinho, ou seja, um pouco maior do que aqueles da praça Cavour, o ponto preferido dos mendigos de São Gennaro, dos cabalistas, dos pequenos pensionistas do governo: um pequeno jardim que será duas ou três vezes maior do que o da piazza Municipio, considero, estes, de pessoas que é inútil mencionar, sob os olhos fechados e paternais dos conselheiros comunais, um pequeno jardim, com uma fonte, onde, provavelmente, haverá um chafariz, desligado nos dias úteis e funcionando nos dias de festa: e, enfim, o pórtico, para evocar na vida moderna, a origem de Partenope, para relembrar um pouco Pompeia, diz o autor do projeto. Na verdade, ele desejava fazer um passeio pompeano, mas esta ideia pareceu um tanto barroca, um pouco boba, que todas as almas boas e distraídas dos assessores perceberam e protestaram. Não haverá o passeio pompeano mas uma pequena parte de Pompeia, com os pórticos, teremos. Ignoramos quem estará sob estes pórticos: não é nem mesmo certo que será construído o primeiro andar. O bairro da Beleza, portanto, resume-se a um jardim, com uma fonte e um pórtico. O seu nome, então, não lhe parece um pouco exagerado, amigo leitor? Não lhe parece que a palavra beleza tenha um sentido diverso e profundo? E que aplicado a uma coisa exígua e ambígua, seja uma grande audácia? E que o projeto e seu autor devem sucumbir sob o ridículo desta audácia?

Para ter este jardim, com a fonte e os pórticos, mostro quanto deve gastar o Município de Nápoles. Deve dar, antes de tudo, ao Banco de subvenções de Gênova a egrégia soma de setecentas mil liras: é verdade que podem ser pagas em trinta anos, estas setecentas mil liras, mas uma dívida é uma dívida, mesmo que for paga em pequenas prestações. Não gostaria de afirmar que o Comune deverá pagar também os juros, porque não sei: mas é provável que para ter a fonte no jardim e os pórticos em volta, para ter isso a crédito, alguns juros deverão ser pagos. Além disso, o Comune permite à sociedade construir um sexto andar em todos os onze edifícios: calculado, assim, a olho, um andar a mais, sobre onze imensos edifícios, pode render à sociedade 
entre noventa e cem mil liras a mais, ou seja, um presentinho de mais de dois milhões de capital, sempre para ter aquilo que já sabem. Como serão mais belos, acolhedores e estéticos estes edifícios de seis andares, em vez de cinco, só Deus sabe! E tem mais: a sociedade tem o direito de não pavimentar mais com pedras as ruas entre os seus grandes edifícios, já que esta pavimentação custa muito: com o objetivo de facilitar ainda mais a posição, o Comune lhe permite de instalar o macadame, o que provoca a existência de barro no inverno, barro que mancha e estraga as roupas; e o pó mais acre, no verão.

Não é só isso: a sociedade possui a concessão da fonte de água sulfurosa: não deve ser grande coisa; mas é alguma coisa. Não lhes parece que, por um jardim, uma fonte e um pórtico tudo custe muito, demais, imensamente? E com tanto dinheiro, tantas concessões, tantas facilidades, o resultado será este: e o suposto bairro da Beleza, será mortalmente feio, se for concluído com seu anacronismo de Pompeia, entre edifícios de seis andares como na América; que o preço dos terrenos, sempre alto e as dificuldades de construção sempre grandes, o Banco de Subvenções, continuará sem vender e continuará sem construir e que no fim da história o bairro da Beleza consistirá em um pequeno jardim, em uma fonte e pórticos vazios, em meio a um vasto deserto árido e poeirento. A sociedade estará parcialmente recuperada de seus problemas, com as setecentas mil liras; o Comune deverá pagar e passando por Santa Luzia nova, o cidadão desinformado morrerá de rir, ao ver aquela trapalhada, e você amigo leitor e eu, cronista cética e pessimista, você e eu que não somos desinformados, lamentaremos aqueles vinte e cinco ou cinquenta centavos, tua parte e minha parte das setecentas mil liras!

\section{A GRANDE RUA}

Quem por acaso ousou ou quem ousará retirar da rua Toledo a sua soberania cidadã? Quem tocará em sua coroa de glória e de vida? Quem poderá igualar, e não vencer o seu fascínio? Quem diminuirá a sua força e o seu caráter? Nada: ninguém. Nem o tempo que tudo modifica e tudo transforma: nem os homens enlouquecidos que deliram para mudar as coisas, de acordo com seu pensamento e capricho: nem os costumes que mudam bizarramente, mesmo que reapareçam em novas formas: nem os fatos regulados pelas misteriosas correntes do destino. Nesta profunda e palpitante artéria, corre um sangue cuja riqueza é magnífica: o seu pulsar pode tornar-se 
tumultuado na febre dos grandes dias, mas nunca pode diminuir sua velocidade: pode alcançar o ápice da alegria, mas não o mínimo da fraqueza: e enquanto todo o imenso corpo da cidade dorme, sob o arco estrelado do céu, sob a luz fria e suave da lua, das colinas floridas na noite até o mar imóvel, a profunda artéria vive e expande a sua parcela de vida, na sombra tênue, entre as casas altas.

A rua Toledo não tem rivais, mesmo entre as ruas mais magicamente belas de Nápoles: nem na admirável via sinuosa que rodeia graciosamente a parte alta da cidade e que é o Corso Vittorio Emanuele: nem na aristocrática e agora deserta, mas sempre nobre e distinta Riviera di Chiaia: nem na indescritível rua Caracciolo, sonho de pintores e de poetas: nem na poderosa Avenida, onde a moderna cidade se desenvolve: nenhuma destas é sua rival, pois estas ruas podem ter a beleza, a força, a graça, a poesia, a tradição, e têm tudo isto e muito mais, em suas histórias e expressões, mas a Toledo possui uma outra coisa, outra coisa grande, imponente, fremente, multiforme, multíplice: possui a vida, a vida.

Quando estiver distante, em um país estrangeiro: se o seu ânimo submergir na triste saudade, é na sua recordação que o seu secreto lamento será mais amargo. Se já esteve aqui e, por variados motivos, a sua existência se desenrola em uma cidade distante: a sua vida parecerá sem graça e gélida. Se sair um dia e não passar por esta rua: a sua jornada parecerá vazia. Se estiver infeliz, entediado, cansado, perdido, descrente de você e de todos: pisem as suas sagradas pedras e como o gole de um vinho inebriante exaltará as suas forças e desaparecerão todos os fantasmas angustiantes e por um instante, por uma hora, por um dia, a existência lhe parecerá, de novo, fácil e leve!

$$
\begin{gathered}
* \\
* *
\end{gathered}
$$

A rua Toledo é a própria vida, pois ao longo dos séculos centenas e centenas de patrícios, de ricos, gastaram suas fortunas para adorná-la de majestosos palácios nos quais viveram, e ali mantiveram o domínio, deixando uma marca profunda e nobre de magnificência que não se apaga: é a própria vida porque na feliz mistura de classes, uma de nossas coisas boas e honestas, juntamente com as grandes famílias, milhares e milhares de famílias ali viveram, ao longo dos séculos, e nos tempos mais recentes, continuarão vivendo, em uma tradição burguesa que possui a sua força, em uma tradição popular que possui a sua força: é a própria vida, porque a fé ergueu os seus santuários, nos quais milhares e milhares de almas vieram, vêm e virão, por caminhos 
conhecidos, diante das imagens queridas, almas piedosas, almas fieis, obedientes a um antigo e doce costume: é a própria vida, porque o comércio e a indústria há séculos, ali montou os seus empórios, em uma tradição de trabalhos, de atividades, de honestidade e de fortuna que, atualmente, chegou ao máximo de seu esplendor. Hospedar-se na Toledo, viver na Toledo, ter uma loja na Toledo, foi, é, como uma herança dos antepassados, como o respeito a um costume sagrado, como a renovação de um pacto com os distantes ancestrais, como uma fé juramentada, como uma necessidade familiar e pública.

Oh coração dos corações: Rua Toledo! A torrente da humanidade, há séculos, a cada dia e a cada minuto rolou, ora suave, ora forte, ora fragoroso, ora clamante, sobre tuas pedras e calçadas: e cada homem, cada mulher que por ali passou, acabrunhado, risonho, fremente, cheio de vida ou de morte, deixou sua marca e seu drama, sua tragédia, sua comédia, o reflexo de sua recordação: e o pequeno ou grande fantasma da história que surgiu, deixou a sombra de sua grandeza ou de sua pequenez: e os nossos e nós os deixamos em tantos períodos da nossa existência, deixamos o melhor de nós, um pensamento, um sentimento, um sorriso, uma lágrima. Ah se a Toledo é a própria vida, é porque cada um lhe fez esta contribuição bela e fatal: é porque lhe deram os soberanos e o povo, em todos os tempos: é porque lhe deram os ditadores e a plebe: é porque lhe deram os poetas e os amantes: é porque todos lhe deram vida, os cientistas, os filósofos, os homens de Estado, os líderes dos partidos, os líderes do povo: todos, todos, as mulheres, os homens, as crianças, os velhos, os doentes, até os mortos dos quais as solenes exéquias deixaram a memória de um nome e de uma pompa lúgubre. Ah é a própria vida, a Toledo e todos a adoram assim, férvida de toda forma alta ou baixa, elegante ou trivial, rica ou pobre, florescente ou mesquinha: e todos a honram, e todos a honraram e não um soberano, não um imperador, não um grande ao chegar aqui, não sentisse o primeiro palpitar longo e forte, nos clamores da gente, clamores que ascendem até o céu sereno!

$$
\begin{aligned}
& * \\
& * *
\end{aligned}
$$

Tudo isto eu pensei, com maravilha, quando percebi que, pela primeira vez, um hóspede soberano chegará entre nós e entrará na Casa do Rei, em um nobre cortejo, sem ter passado pela rua Toledo: e ao ouvir isto, os milhares de bons cidadãos da rua Toledo lamentam profundamente, desiludidos em suas legítimas esperanças, e centenas de comerciantes e de industriais que, de tal acontecimento belo e popular, esperavam não 
apenas diversão para os olhos, mas honesta vantagem para seu trabalho. Motivos de força maior que nós ignoramos fizeram escolher um itinerário belo, porém muito mais breve: e cortaram, com involuntária crueldade, certamente, a própria vida napolitana, a antiquíssima e fiel rua de Toledo, aquela que leal e entusiasticamente festejou os seus reis e seus hóspedes, aquela que também soube adornar-se de tecidos e guirlandas e fez chuvas de flores sobre as rainhas e princesas. Motivos de força maior! Nós os desconhecemos: e devem, certamente, ser muito fortes e muito respeitáveis: nem o itinerário, agora, pode ser mudado. Talvez! Mas como em Paris, logo depois que os Soberanos da Itália atravessaram a Avenue des Champs Elysées e a inesquecível praça da Concórdia, para dirigir-se ao palácio das Relações Exteriores, sem passar pelo centro da Paris viva, o coração de Paris a praça da Ópera, encontrou-se um modo de fazê-los sair, novamente, e de fazê-los atravessar a Avenue de l'Opèra, que se encontre aqui também um modo de fazê-los atravessar, oficialmente, em uma hora estabelecida, o Presidente da República, pela rua Toledo, por toda a rua Toledo: e que isto se promulgue: e que se contentem, assim as justas expectativas de uma rua onde tudo de Nápoles se concentra e se exprime: e que se dê aos olhos curiosos e doces de Emile Loubet que vem de uma das mais belas cidades do mundo este espetáculo indescritível. Se o Presidente da República for embora sem ter visto a rua Toledo, em uma tarde de primavera, lotada de gente, adornada de flores e bandeiras, com uma multidão flutuante e ondulante, é como se não tivesse visto Nápoles.

\section{GUERRA AOS LADRÕES}

Um desagradável odor de mofo, de coisas antigas e usadas, mantidas muito tempo fechadas e colocadas para fora, se espalhou pelo ar que respiramos, há alguns dias. Nos primeiros comícios, nos primeiros proclamas, fingindo uma certa seriedade, foram tirados dos armários destruídos da retórica administrativa: o partido clericoborbonico, o partido clerico-moderato, o partido socialistoide, o partito anarcoide e,

até, vejam só, aquela consumadíssima coisa que é o partito liberal. É como um amontoado de ferros velhos empoeirados e enferrujados, retirados de um quarto de bagunça: como um fardo de trapos rasgados e sujos, largados no chão. O pó acre se eleva de todas estas migalhas: o mofo gruda, viscoso, nas mãos de quem se aproxima: e o ar puro torna-se infectado. As pessoas passam, tapam o nariz, erguem os ombros e 
riem de escárnio. Por muitos anos, estas palavras, estas frases, tiveram um conteúdo de vida: mas o tempo passou e tudo mudou: mas isto é vazio, frouxo, sem cor, sem sangue, como o balão de gás leve, que voava, tinha as belas cores da alegria, mas que se tornou um pequeno trapo inútil depois que a criança o estourou. Nada disso existe mais: nada disto responde à renovada consciência moderna: nenhuma destas fórmulas tem mais expressão ou influência. Observem então a vida real! Observem na vida real, todas as profundas transformações que surpreendem. Existem católicos que são italianíssimos: existem anticlericais que são crentes, existem clericais que são democráticos: existem democráticos que são imperialistas: existem liberais que restaurariam a pena de morte: existem republicanos autoritários e absolutistas: existem socialistas que adoram o Rei: existem radicais perfeitamente monarquistas: existem monarquistas que falam um mal horrendo da monarquia: os maçons que detestam o clero, creem no Arquiteto do Universo: e os borbônicos, enfim, já que também se fala disso, os borbônicos se resumem àquele encantador homem de idade - ele envelhecerá, mais tarde - que é o duque de Regina, caro a todos, reverenciado por todos os partidos, subpartidos, facções e subfacções. A paixão tumultuada das ideias, o turbilhão cada vez mais precipitado das opiniões, todo este enorme cataclismo moral, de onde sairá, amanhã, e já surge esplendorosa como a aurora, a consciência nova, e inverteu assim toda ordem de critérios e de conceitos que, de fato, aqueles que, ainda, se apegam ao funesto lixo do passado, aqueles que tentam brandir as armas destruídas e sem corte, que tentam agitar uma bandeira desbotada e esfarrapada, despertam um sorriso de ironia e de piedade!

Mas nesta bizarra confusão, a nossa cidade, esta nossa Nápoles, busca um guia para seu caminho, busca a verdade no bom senso. Nápoles diz, secretamente: pronto, preciso ressurgir. Não apenas devo viver, mas devo desenvolver todas as minhas forças sociais e individuais: cada um dos meus cidadãos, mesmo o mais obscuro, o mais desconhecido deve ter trabalho, saúde, proteção, educação e todos os cidadãos e, eu, Nápoles, devo assumir o meu lugar belo, nobre, forte, na vida operosa e eficaz moderna. Não apenas eu desejo ressurgir; mas todos os italianos que têm coração, querem a minha ressurreição: mas todos os meus irmãos do norte me estendem a mão firme e afetuosa, para que eu ressurja: mas os homens do parlamento, os homens do Estado, o Soberano desejam ardentemente a minha ressurreição. Esta, porém, deve se realizar com 
todas as formas mais amplas, potentes, limpas e transparentes. Para que eu renasça devem chegar a mim os capitais estrangeiros do norte e que sejam abençoados, desde que encontrem às minhas portas e entre meus muros, quem lhes dê uma recompensa, se quiserem entrar. Para que eu ressurja aqui devem formar-se amplos empreendimentos industriais, onde quem é trabalhador, encontrará mercê honesta e ajuda social, onde quem é proprietário encontrará ganhos honestos, onde quem é capitalista poderá investir de forma honesta e segura o seu dinheiro, onde todas as inteligências belas e vívidas napolitanas poderão encontrar campo de ação, onde toda esta vivaz força de engenho, poderá se manifestar em uma obra útil e eficaz: mas estes empreendimentos industriais devem ser feitos à luz do dia, sem transações duvidosas, sem concessões espúrias, sem prêmios, sem propinas; e como foi feito em outros lugares, em Milão, em Gênova, em Turim, onde centenas de tais empresas nasceram, vivem e prosperam, sem que tenha sido necessário corromper ninguém, aqui também, na minha nova atmosfera moral, esta bela coisa, o negócio honesto, o negócio simples, o negócio nos quais não há ganhos ilícitos ou exagerados, em nenhuma parte, mas nos quais todos possam prosperar, o negócio deve surgir, desenvolver-se, ampliar-se, trazer o bem e ser parte integrante da minha ressurreição. Para que eu ressurja, completamente, os bancos que aqui existem devem ajudar o meu povo, ajudar as indústrias honestas, ajudar as iniciativas honestas e livrar da usura o povo, os industriais e todos aqueles que precisam de crédito: e devem ser fundados outros bancos, com dinheiro vindo de fora, com dinheiro daqui, e todos os novos, os velhos não devem pesar sobre os mais fracos e miseráveis, não devem servir a objetivos indefinidos, mas ter, sim, também os bancos, um critério moral de assistência à minha população.

$\mathrm{Eu}$ invoco o trabalho, invoco as sociedades, invoco as indústrias, invoco os bancos, que deverão redimir a minha miséria, o meu ócio e a minha incivilidade: mas tudo isto deve ser feito de uma outra maneira, não mais como antes, mas de uma maneira correta, leal, franca, em uma forma das mais íntegras, com uma probidade perfeita, com aquele rigor de consciência, por todas as partes, que, em tanta agitação de coisas, é o caminho da verdade e da vida".

E, a propósito das não iminentes mas próximas eleições administrativas, sabem o que diz, Nápoles? Nápoles diz isto: A mim pouco importa que no Conselho Comunal haja clericais, borbônicos, moderados, liberais, democratas, socialistas ou anarquistas: tudo isto me é indiferente. Eu quero homens honestos: quero consciências seguras: quero almas austeras. As suas opiniões políticas não me interessam: apenas seus 
sentimentos morais me interessam. Não quero ladrões, no Comune; e ladrões não são apenas aqueles que levam meu dinheiro, o meu pobre e escasso dinheiro, mas todos aqueles que ajudam os ladrões ou que fecham os olhos e permitem que eu seja roubada. Não quero, no Comune, nem negociantes inescrupulosos, nem compadres de negociantes inescrupulosos, nem representantes de negociantes inescrupulosos, nem amigos dos amigos dos negociantes inescrupulosos. Existem, entre os liberais homens honestos? Verei: acreditarei neles depois que vir e souber: e mandarei ao Comune estes liberais honestos. Os clericais não amam Roma capital, não querem festejar o vinte de setembro $^{63}$, se irritam por dever reverenciar o Rei: mas são honestos? Votarei neles, já que confio em sua probidade: e, mais tarde, pensarão em não confrontar os meus sentimentos de italianidade. Os socialistas são violentos, radicais e muitas vezes utópicos: mas são honestos e querem, com todas as forças, o triunfo da honestidade como eu quero? Votarei neles, come um único homem. Votarei em qualquer um que pareça, diante de todos, ser um homem íntegro. Um homem íntegro pode errar, mas não pode me trair, um homem íntegro pode se enganar, mas não pode me vender. Diante do mundo que conheceu os meus longos sofrimentos, diante da Europa que se surpreendeu comigo, como se surpreende com um covil de malfeitores, diante da Itália, que me olhou dolorosamente surpresa, devo, ainda uma vez e, agora, mais do que nunca, demonstrar que os meus sofrimentos foram provocados por alguns de meus poucos filhos infames, que o covil não era nada mais que um pequeno buraco de imundos roedores, que tenho milhares e milhares de cidadãos bons e honestos e que, entre estes, posso, desejo escolher mais uma vez, os honestos que devem me administrar. Qualquer veste que cobrir o homem de consciência traiçoeira, eu reconhecerei: qualquer máscara que cobrir seu rosto, eu a farei cair: em qualquer modo que tentar me enganar, não conseguirá mais.

Muito sofri na honra e na prosperidade: muito chorei de vergonha e de indignação. Preciso começar a salvar-me, se quero ser salva por tudo, por todos. Nas minhas mãos está a minha primeira ressurreição: aquela da minha existência, moral, ou seja do meu decoro social. Mostrarei ao mundo, à Europa, à Itália que de todos os dons da sorte, sou digna, que de todas as ajudas fraternas, sou digna, eu, Nápoles, cidade de gente honesta, mandando ao Comune apenas as pessoas honestas, pedindo a elas, que assim se prossiga e se exalte a minha reabilitação!

${ }^{63} \mathrm{Em} 20$ de setembro de 1870, as tropas do Reino da Itália entraram em Roma, garantindo a unificação da cidade com as outras regiões do país e pondo fim ao poder temporal dos papas. 


\section{CRISTO DIZ...}

Mais justo e oportuno, talvez, seja ignorar, querer ignorar, este singular, intenso e potente dissídio de Torre Annunziata, o que é o trust dos industriais, porque e como surgiu, em quais acordos se baseou e para qual entidade financeira ou pessoa se destinam, divididos ou reunidos, os muitos benefícios e desvantagens do trust. Provavelmente, aliás, é certo que os industriais de Torre Annunziata não são odiosos e cruéis capitalistas se analisamos um por um: talvez, venham do povo trabalhador e devam ao trabalho árduo e à boa sorte de seus pais, devam a seu próprio trabalho árduo e à sua boa sorte, se o acaso os presenteou com a riqueza e se assim for, não pode seu coração de boa memória ter esquecido de onde seus pais começaram, de onde eles mesmos começaram na juventude e esta memória indelével deve ter amenizado, ameniza, de qualquer forma, a soberba e a dureza de quem possui dinheiro e poder. Também é certo que nestes últimos dois meses de luta verdadeiramente heroica, os industriais suportaram e suportam graves perdas de dinheiro, cujas consequências não podem ser subitamente percebidas, já que cada um deles possuía a sua reserva e para muitos a fortuna é muito forte: também é certo que muita energia foi gasta e muitas oportunidades perdidas, e que estes danos são profundos, tão profundos que muito tempo, muita força, muito trabalho e muita paciência são necessários para compensálos. Respeitemos a justiça, em cada uma de nossas palavras, se quisermos que o povo acredite que somos justos e íntegros; e não culpemos as pessoas que possuem as maiores fortunas, com a desculpa de que são ricos e que isso ofende o pobre. Embora a sorte cada vez mais comece, em todos os lugares, a nivelar a riqueza, a impor, sobre tudo, determinadas leis, determinados deveres e obrigações, a ponto de lentamente diminuí-la, quase retirando-lhe o poder e a amplitude, quase mostrando-lhe constantemente o fantasma dos menos felizes, dos mais obscuros, e induzindo-a a olhar e a temer este fantasma, como coisa viva, os ricos existirão sempre, no mundo, e o vivo engenho, a sólida vontade, a férrea tenacidade, o acúmulo de circunstâncias que chamamos Fortuna, terão sempre os dons da terra e do céu; e é injusto puni-los, simplesmente porque existem seres sem mentalidade, sem vontade, miseráveis de alma e de corpo, destinados a uma vida humilde, da qual nenhuma lei, nenhum Estado e nenhum homem pode livrá-los. A riqueza tem muitos justos perseguidores, quando é 
tirânica, áspera, orgulhosa e sem piedade: esta também tem, porque é apenas riqueza; deixemos que se defenda como puder, se puder, se souber, se quiser e se conseguir!

Mas devemos oferecer toda a solidariedade de nosso coração fraterno, pleno de um profundo sentimento de bem a estes cinco mil operários, que, há cerca de setenta dias resistem a todo tipo de tristeza física e moral e de Torre Annunziata dão um exemplo de firmeza, de constância, de sacrifício verdadeiramente admirável. ${ }^{64}$ Que os olhos de todos os trabalhadores do mundo se fixem sobre esta bela cidadezinha que se reflete no mar, e que um senso de grande respeito nasça por estes operários que, sofrendo privações, servem não apenas a sua causa, mas à causa de todos aqueles que trabalham. Estão há mais de dois meses em greve, pacientes, atentos, inacessíveis: e seus sofrimentos materiais são grandes. Pouco a pouco, o dinheiro para manter a greve acabou e eles passaram a ver que estavam cada vez mais escassos os fundos da liga e se contentaram com pouco dinheiro. De vez em quando, chega alguma generosa contribuição, mas os trabalhadores são muitos, as necessidades são grandes e depois de alguns dias a privação, a miséria, sim, digamos a miséria torna-se mais pesada, mais lúgubre e mais negra. Sabem o que comem muitos deles? Batatas! Os camponeses, os fazendeiros nos campos com ânimo misericordioso, permitem que as famílias dos operários façam a colheita sem incomodá-los; e toda manhã, os filhos dos operários saem com sacos nas costas, em direção aos campos e plantações, nas propriedades, para colher batatas: não custa nada e é um alimento, pelo menos um alimento quente, cozido na água com os quais se dá de comer a homens, mulheres, crianças e velhos. Centenas de episódios comoventes que causam piedade poderiam ser narrados sobre eles sobre o modo como eles se ajudam mutuamente: e como os mais fortes dão força aos mais fracos: e como as mulheres são mais ardentes e mais firmes: e como nenhum fraqueja, nenhum trai nem ousa trair. São cinco mil, mas a vontade é apenas uma. Como uma barra de ferro que não se entorta, que não se move, e não se rompe: e mesmo assim, muitas vezes, suas entranhas se corroeram pela fome: muitas, não podem dar nada a seus filhos: pouco a pouco tudo aquilo que tinham em casa, não tem mais, empenhado

\footnotetext{
${ }^{64}$ Matilde Serao refere-se à greve de 1904, que teve início em 12 de abril com os portuários e contou com a adesão de outras categorias. Terminou dois meses depois, com as reivindicações atendidas: a reintegração dos trabalhadores demitidos.
} 
ou vendido: seus amigos, seus companheiros, seus irmãos, os ajudaram, como puderam, mas estes auxílios também foram limitados, não podem consolar, aliviar um grupo tão grande. São cinco mil e parecem apenas um homem cuja vontade invencível consegue realizar um milagre cotidiano, há setenta dias: sofrer privações, não lamentar-se e não ceder em nenhum ponto e acreditar, sim, acreditar na própria vitória, já que é a fé no ideal que acaba, sempre, brilhando! São cinco mil e votaram, como um único homem, no bem estar de sua coletividade por um melhor futuro, e neste voto social que fizeram, dão, como antigos heróis, o melhor de seu sangue e o melhor de suas forças. São cinco mil, e, agora, com sua grande coragem, vencidos todos os obstáculos, o sacrifício de todos continua, sempre e não acabará sem triunfo, para que, centenas deles não fiquem na rua, sem trabalho, sem pão!

$$
\begin{aligned}
& * \\
& * *
\end{aligned}
$$

O monte da Quarentena, na Palestina, surge entre as férteis planícies onde resplandece e corre o límpido rio Jordão e o grande deserto onde fumega o cinzento Mar Morto, que sepultou, nas suas águas revoltas e traiçoeiras Sodoma e Gomorra. Esta montanha, não alta, é rochosa, duríssima: não nascem plantas, não nascem flores. E ali Cristo passou quarenta dias orando, em solidão, em penitência, depois que o Precursor, o batizou nas águas do Jordão. Estava solitário na montanha: e o Maligno o tentava. Cristo estava exausto pelas orações e pelo jejum. Dizia o Maligno: Morres de fome; se és filho de Deus, faz um milagre e transforma em pão estas pedras. Cristo se calava. Faz, faz, um milagre, repetia o Maligno, e transforma em pão estas pedras! e Cristo, então, olhou para ele e disse: o homem não vive apenas de pão. Ah que palavras dissestes, Senhor, nessa montanha e como estas estão entre as mais grandiosas, elevadas, puras e ardentes de todos os tempos, em todas as consciências! Há dois mil anos vós a pronunciastes, em um momento sagrado da elevação da alma, combatendo com o Tentador que lhe oferecia todos os bens materiais da terra, sobre uma montanha árida e nua, em uma solidão sem eco, em um momento supremo: e a palavra vibra no mundo dos espíritos, como um conforto e uma exaltação. Para os pobres, para os fracos, para os infelizes, para os sofredores, que esta palavra foi dita: contras os ricos, os poderosos, os soberbos e os maus, que foi pronunciada: é pela guerra que sempre existiu, que nunca acabará, entre os miseráveis e os perdulários, que isto foi proclamado. O que importa a pobreza, se o homem não vive apenas de pão, mas de um conteúdo espiritual que torna a sua alma lúcida e formidável, e vence as suas limitações 
físicas? Que importa o sofrimento, se não apenas o pão é alimento do homem, mas um conforto interior que o torna mais forte do que qualquer tristeza? O que importam a privação, as fadigas, o duro sacrifício, quando para vencer estas torturas, não apenas o pão é necessário, mas uma energia moral que beira o heroísmo? Milhares, milhares destes soldados desconhecidos da alma tombaram em todo o mundo, vitimados pela fome, pelo frio, pelas doenças, mas transmitiram suas ideias, sua chama, e sua esperança aos outros combatentes: mas esta batalha contra todas as tentações baixas e ignóbeis, esta batalha em nome do espírito triunfante sobre a carne, já teve milhares de clamorosas vitórias. Oh mineiros sufocados nas entranhas da terra, oh trabalhadores dos campos curvados sobre a enxada, oh operários extenuados pelo trabalho pesado, nas fábricas, a palavra do monte da Quarentena é o bálsamo que cura, dá vida, exalta: sejam ou não cristãos. Aquele que era pobre e amava apenas os pobres, que era obscuro e que perseguia os poderosos, que era humilde e desprezava o orgulho, aquele que devia viver e morrer, por todos os desventurados, disse a Satanás, senhor das riquezas humanas: O homem não vive apenas de pão. A cada vez que uma criatura da terra prefere a fome ao opróbrio, prefere o frio à vergonha, prefere a morte à vileza, a cada vez que uma criatura humana em luta com a fortuna de outros, com a força de outros, com a tirania de outros, não cede, não faz acordos, não se curva, e às vezes vence e às vezes morre, mas morre vencendo, a frase cumpriu seu milagre espiritual.

\section{O PÃO DA ALMA}

Quando o diretor do MATTINO encontra-se, por acaso, em polêmica com o jornal ROMA, ele o chama, na maioria das vezes, de o jornal dos porteiros. Isto sempre me fez rir.

ROMA poderia ser o jornal dos porteiros, como já é o jornal dos comerciantes que voltam do almoço entre uma e duas da tarde, mas não é. Os porteiros napolitanos não sabem ler. Fazendo uma pesquisa curiosa e bizarra, os senhores poderão encontrar, em uma centena de porteiros cerca de quatro a cinco que sabem ler, não mais do que isso; e para desempenhar as tarefas da profissão, variadas e de certa dificuldade, os porteiros napolitanos desenvolvem a agilidade natural de sua competência, transmitem recados, distribuem os cartões de visita, dividem as cartas e os jornais, mas não sabem ler. Passando aos cocheiros, gente ágil como nunca se viu igual, peçam a um deles, por 
exemplo, que o leve à rua Partenope, número dezoito: antes de tudo, ele lhe perguntará se é o teatro Partenope: e, em segundo, quando chegarem, com sua carruagem, à rua Partenope, ele não saberá onde encontrar o número dezoito: o cocheiro napolitano raramente sabe ler e ignora quase sempre a figura gráfica dos números, mesmo sendo apaixonado jogador de loto, como é. E, passando de classe em classe, não apenas o estrangeiro se dá conta e se surpreende e lamenta que entre o povo napolitano, tão inteligente, tão vívido, tão rápido, seja imenso o contingente daqueles que não sabem ler, mas vocês mesmos, vocês, napolitanos, a cada vez que se encontram diante de um ignorante, um analfabeto, sentem o desgosto agudo de tanta barbárie e obscurantismo; e, às vezes, são tomados pela repugnância de tanto descaso e abandono, na qual foram deixadas estas pobres pessoas. E, de vez em quando, naquelas tristes conversas com algum espectro da noite, que a melancolia da deambulação noturna por aqui faz encontrar, naqueles encontros singulares e tétricos, com um rapaz de má vida, com um catador de pontas de cigarros, com um vendedor de café ambulante, vocês ouvem o bordão profundo, áspero, cruel, no qual o povo napolitano resume o seu profundo respeito pela cultura e a dor da própria ignorância, um cruel bordão que emana do interior da alma, como uma provocação, como uma amarga reprovação às classes mais altas. Vocês se interessam pelo moleque de má vida, pelo inacreditável catador de pontas de cigarros, pelo singular vendedor de café que circula como um fantasma, desde o amanhecer, pelas ruas napolitanas: e lamentam a sua sorte e ele se lamenta, assim, curvando os ombros, filosoficamente. Mas sabes ler?- o senhor lhe pergunta. Ele olha, responde: Signò, si sapesse leggere nun starria cca: starria a Palazzo. ${ }^{65}$ Para o povo napolitano, quem sabe ler não pode ser catador de pontas de cigarros, vendedor de azeitonas, larápio noturno, mas pode tornar-se Rei ou algo semelhante ao rei, morar na Reggia e não em uma espelunca ou nos degraus de uma igreja, comandar os homens e não terminar no cárcere ou no hospital.

$$
\begin{gathered}
* \\
* *
\end{gathered}
$$

Centenas, milhares de meninos e meninas pululam, se misturam, se amontoam em todas as ruas, das mais aristocráticas às mais populares, criaturas seminuas, descalças, pouco cobertas ou vestidas: e não se sabe de onde vêm e para onde vão, não se sabe a quem pertencem, como vivem, como morrem. No entanto, eles têm mãe e pai,

\footnotetext{
${ }^{65}$ Se soubesse ler não estaria aqui, estaria em um Palácio. (dialeto napolitano).
} 
estes meninos e meninas miseráveis e gostariam, estes infelizes pais, desempregados ou empregados em um trabalho mal remunerado, fatigante, duríssimo, gostariam, estes pais de mandar a uma creche, a uma escola, estas criaturas de suas entranhas, gostariam que além do pequeno e rude pão do corpo, dado, ah, com rigorosa medida, lhes fosse dado, por quem tem a obrigação rigorosa, por quem tem o sacrossanto dever, o pão da alma, a instrução. Desejo insano! Deve faltar frequentemente a esta imensa multidão de pequenos e pequenas, de moças e rapazes, o modo de matar a fome já que, ao que parece, a pobreza napolitana é muito pitoresca e os guardiões da estética adoram esta manifestação triste e poderosa de dor social: deve faltar, sem dúvida, o pão da alma, que deveria dar frutos de bem intelectual e moral, deve faltar sem dúvida a instrução. Existe entre o povo, uma instituição estranha e característica: uma espécie de pequena escola mantida por alguma mulher simples, em um basso mais espaçoso do que os outros: as mulheres, operárias, criadas, lavadeiras, passadeiras levam seus filhos e suas filhas, de manhã, antes do trabalho e pagam um soldo por dia, as mais privilegiadas, digamos assim, vinte soldos, e quinze soldos por mês, as mais desventuradas. A proprietária da escolinha, não ensina nada a todas aquelas criaturas: deixa-as um pouco fechadas e depois permite que corram livremente: dá bronca, sempre: grita: dá uma palmada no traseiro: choro, gritos, soluços: mas, enfim, é responsável, por um soldo ao dia, por três centavos, por dois centavos, por cada criança até a noite. E lembro-me, também, na minha juventude, e com meu diploma de escola normal que me foi dada, por três anos, enquanto estava conquistando este diploma, a missão de dar o pão da alma às filhas $d o$ povo, continuamente lembrada, a cada problema de aritmética errado: e enfim levado milagrosamente este objetivo do diploma, o dever do estágio de professora, em uma destas escolas, frequentadas por estas filhas do povo, a quem eu devia ensinar a ler e a escrever.

E fui cheia de interesse, de uma distinta ânsia secreta, e até de emoção, para ser estagiária e me vi diante de muitas meninas decentemente vestidas, algumas com elegância. Interroguei uma por uma estas filhas do povo, para saber quem eram e de onde vinham; e descobri, pouco a pouco, que eram filhas de profissionais liberais, de funcionários, de negociantes, de comerciantes, e entre as setenta e duas estudantes, uma somente, uma, era filha do povo, maltrapilha, pálida, impertinente, inteligentíssima, fascinante. Uma! Mais tarde, saí da escola, porque havia terminado o estágio: a pequena Buonfantino, inesquecível no meu terno coração, desapareceu, porque morreu, de 
tuberculose, aos onze anos. Era uma filha do povo: mas a escola não havia sido feita para ela!

E não há escolas em Nápoles! Não há! Às vezes, nós nos reunimos, damos um baile esplêndido, com uma loteria de objetos de arte, toda a grande sociedade napolitana (e a menor também) comparece e a Cruz Vermelha arrecada trinta mil liras: mas faltam escolas enquanto o corpo e a alma de milhares de meninos e meninas apodrecem nas ruas lamacentas. Não há escolas: enquanto nós por um mês, organizamos uma Kermesse enorme, com sessenta damas nos quiosques, e oitenta ou noventa cegos de Caravaggio, que já herdaram duas ou três fortunas, recebem vinte e cinco mil liras. Não há escolas: eu e outras damas da Sociedade Margherita, organizam, organizamos conferências, recitais, excursões, para ajudar vinte e dois ou vinte e sete cegos em suas próprias casas, comprando-lhes um piano, um fonógrafo ou uma bicicleta! Não há escolas em Nápoles, e as professoras morrem de fome e os jovens do povo acabam no vício, na corrupção, na desonra, no crime: e se surpreendem com as estatísticas da vergonha, do crime em Nápoles, quando esquecem que não há escolas, que alguma boa alma de assessor reivindica, para que se abram outras, enquanto o malsucedido projeto do bairro da feiura, em Santa Luzia, custa um milhão e duzentas mil liras, porque isto é cômodo a um assessor qualquer! Não há escolas em Nápoles, e estes católicos que estão no Município de Nápoles, não se envergonham de deixar que perdure esta coisa infame, que é o analfabetismo, que nos faz enrubescer, diante não apenas dos estrangeiros, que riem ironicamente, ironizando, mas diante dos italianos da Lombardia e do Piemonte. Não sei há quantos anos se delira e se gasta pelo Maschio Angioino ${ }^{66}$, sempre a gangrena mais repugnante devora o povo napolitano, preso às trevas da ignorância: e nem mesmo os católicos que deveriam ter aprendido com Cristo Nosso Senhor o amor aos pequenos e aos oprimidos, não fazem nada. Os socialistas solicitavam a merenda escolar: e tinham razão, mas antes da merenda que seria destinada aos filhos das pessoas privilegiadas, abrir escolas, abrir mais de cem, em todos os lugares, esta é a caridade social, a solidariedade social! Ao invés disso, nós nos ocupamos se o lustre de S. Carlo $^{67}$ impedirá a visão daqueles que estiverem na quarta e na quinta fila: questão

\footnotetext{
${ }^{66}$ Fortaleza de Nápoles.

67 Teatro de Nápoles.
} 
gravíssima. Aqueles que se mobilizam por este detalhe, deveriam informar-se um pouco, assim, para saber, quantos dos prisioneiros dos cárceres de São Francisco, de São Eframo e de Santa Maria em Agnone sabem ler. Depois, cubram o rosto com as mãos: se tiverem enrubescido um pouco!

\section{O PAI DO POVO}

Os meus olhos viram o imponente e tocante espetáculo; e a comoção que provocam as coisas grandes e sinceras, agitou o meu espírito. Um povo gritou de desespero, gritou de cólera, chorou de dor, porque Ettore Ciccotti ${ }^{68}$ não é mais deputado de Vicaria: e por três dias e três noites, este furor do povo, repleto de soluços e lágrimas, expressou-se nas formas antigas, simples e pueris da revolta popular: a pedra recolhida nas ruas suburbanas e que corta o ar, assobiando, o rústico pedaço de madeira que nem é um bastão mas que defende e ataca, o vaso de flores lançado da janelinha da casa: e um desejo louco, fúnebre, de morrer, atirando-se diante das armas carregadas e prontas para abrir fogo, as mulheres atirando-se sob os cavalos dos soldados, assim, ávidas de morte! Se mais trágica, se infinitamente mais trágica não foi a aventura do povo de Vicaria, deve-se ao próprio Ettore Ciccotti que aconselhou, em discursos e por escrito, a calma, a paz, em nome do profundo vínculo entre ele e este povo de Vicaria: deve-se à sua partida, à sua ausência, ato de terno altruísmo, com o qual se subtraiu ao terrível entusiasmo e aplacou, assim, também o desenho de revolução e de morte: ainda uma vez, ele salvou o bairro Vicaria do sangue e do massacre. E a ira ensandecida, lentamente, foi aplacada, já que estes poderosos ímpetos das massas não podem e não devem durar: e ficou, espalhada por todos os lados, em centenas de episódios comoventes, a dor de ter perdido Ettore Ciccotti, como deputado de Vicaria. Nas esquinas, um homem gira a manivela de um pequeno órgão e começa a tocar uma música bizarra: outro homem canta: e a canção fala de Ciccotti, o pai do povo, e todos se põem a cantar em coro, enquanto cresce a multidão: alguns cartões com o retrato de Ciccotti circulam entre as pessoas: as mulheres os seguram, beijam e guardam entre os seios. Um vendedor de jornais passa, é um velho: a cabeça está enfaixada: foi ferido, em uma daquelas noites: e caminhando a passo lento, com voz débil, grita o nome do jornal

\footnotetext{
${ }^{68}$ Político italiano (Potenza, 1863 - Roma, 1939). Formado em Direito pela Universidade de Nápoles, fez parte da Câmara dos Deputados e do Senado. Filiado ao Partido Socialista, opôs-se abertamente ao fascismo.
} 
e acrescenta, como refrão: ànn'acciso' u padre nostro Ciccotti. ${ }^{69}$ Em uma esquina de Porta Capuana, há um grupo de mulheres e uma delas fala: está excitada, tem lágrimas nos olhos, narrando não sei qual benefício que ela teve de Ciccotti; e as outras, pouco a pouco, começam a gemer a seu redor: e como se alguém tivesse morrido, elas exclamam: avimmo perdute nu patre, nu patre $!^{70}$ Em outro lugar, um homem bem vestido, um senhor, enfim, mas conhecido no bairro, é rodeado por outras mulheres, que lhe contam suas desgraças, e ele ouve, pensativo, com a cabeça abaixada: e o refrão, mais melancólico, mais triste, recomeça: eles nos tiraram, sinhô, eles nos tiraram! Entrem, não nas lojas da burguesia de Vicaria, mas nos bassi de são João em Carbonara, da rua Santos Apóstolos, das travessas do Nuovo Corso Garibaldi, de Porta Capuana, e em cada uma daquelas espeluncas onde falta ar e luz e onde o povo napolitano vive, por culpa de seus maus governantes, como se não fossem homens e nem cristãos, e os senhores encontrarão o retrato de Ettore Ciccotti, ao lado da imagem da Virgem. Digam seu nome a um destes homens ou mulheres do povo: e verão suas fisionomias inflamadas e exaltadas, pois ele é o pai, não o que lhes deu a vida, mas o pai de suas misérias, de suas abjeções, de suas dores!

E estas pessoas de Vicaria não são eleitores: são povo. E uma outra coisa. É uma multidão de desventurados que nasceram com o legado de epidemias, da pobreza e do vício e pelos quais ninguém tomou uma atitude, para que estes desventurados fossem, em nome de Deus, em nome da natureza, considerados irmãos, mais infelizes, mais desgraçados, mas irmãos; são desventurados; a quem ninguém pensou em dar pão e trabalho, pois antes que o pão e o trabalho cheguem a eles, milhões de ladrões elegantes precisam subtraí-lo ou extorqui-lo: são desventurados aos quais ninguém dá uma escola, pois os senhores do Comune deliram para investir um milhão em uma sociedade que está para falir e não providenciam que se abram escolas: são desventurados para os quais o trabalho pesa, sobre a vida, raro para se encontrar, difícil de durar, mal remunerado, precário, incerto, irrisório: são desventurados que muitas vezes, vêm do crime ou nele acabam, mas não por culpa deles, por culpa de outra sociedade, cega, surda, indiferente, dura como uma rocha.

\footnotetext{
${ }^{69}$ Mataram nosso pai Ciccotti (dialeto napolitano).

${ }^{70}$ Perdemos um pai, um pai! (dialeto napolitano).
} 
Não são eleitores! Povo: povo verdadeiro, numeroso, obscuro, em multidões temíveis ${ }^{71}$, cujos rostos mostram os cansaços e as tristezas, com vozes roucas, enfraquecidas pela fome e pelas doenças, com os germes hereditários que um atavismo, ah, de pobreza, os colocou, com os instintos do mal exaltados pela longa existência de misérias, e de pranto, com a inclinação ao mal sim, ao mal, que colocou este centenário e cruel abandono obstinado da sua infeliz sorte; e a Sociedade infame fecha os olhos para não ver este povo, que foge, para apagar a sua existência e crê que a fuga seja a salvação. Oh o senhor não fugiu, Cristo, Senhor, este povo que, no tempo dos tempos, era oprimido por todo tipo de mal e expulso pelos poderosos e soberbos! O senhor os procurou, em todos os lugares: onde quer que houvesse um miserável, um sofredor, um pecador, um doente, um criminoso, o senhor lhe estendeu a mão, o abraçou, chamou de filho: o senhor permitiu que a mulher do mal, emblema, de todas as pecadoras, de todas as criminosas, se curvasse a seus pés pedindo perdão e o senhor perdoou, nela, todos os pecados das pobres mulheres, fracas, decaídas, frágeis, cuja virtude não é firme.

Ah, o senhor não fugiu, este povo, ou Leon Tolstoi, ou o mais cristão entre os cristãos, o senhor que tratou como irmãos, apenas aqueles que sofrem, o senhor que revelou à sociedade hipócrita e perversa todos os seus enganos e todas as suas infâmias, que desceu entre os desgraçados e desgraçadas, e apenas eles, nos seus livros, atingiram a honra da sua piedade e da sua ternura. Pai do povo, era o Nosso Senhor Jesus: e pai foram todos que desprezaram os ricos e cruéis e que curaram as chagas físicas e morais dos infelizes: e pai será chamado, na nossa vida, quem se ocupar apenas em enxugar as lágrimas de quem chora, de erguer as almas deprimidas, de oferecer uma consciência moral àqueles que a tiveram destruída pelo seu destino. Este nome de pai foi o povo de Vicaria quem deu a Ettore Ciccotti, porque ele não fechou os olhos, para não ver o horror daquelas existências, porque ele não fugiu, oprimido por um sentimento de terror e de impotência: porque ele permaneceu, corajoso, paciente, indulgente, às vezes consolando e fazendo o bem, procurando erguer o espírito ou socorrendo o corpo: porque ele teve piedade, mas não uma piedade pomposa e ultrajante, não uma piedade estéril e infecunda, mas uma piedade humilde e fraterna, mas uma piedade eficaz e operosa, mas uma piedade civil e gentil. Inúmeras vezes, este povo de Vicaria esquecido, abandonado, traído, encontrou em Ettore Ciccotti não o hipócrita que coloca a mão na carteira e dá duas liras, comprando duas liras de tranquilidade de consciência,

\footnotetext{
${ }^{71}$ No texto de partida o termo era paurose, que pode ser tanto temeroso quanto temível.
} 
mas um coração paterno, cheio daquela celestial indulgência que é a força dos líderes do povo, mas uma alma viril que, ao mesmo tempo, disse a palavra que alivia e emprestou a obra que redime, que consolou a dor e abriu os espíritos à esperança de uma vida mais consciente e mais civilizada. Não se surpreendam se as mulheres violentas de Porta Capuana e as mulheres de má vida de via Martiri d'Otranto o adoram! Assim Madalena adorou Cristo: assim Maslova, perdida e criminosa, adorou Tolstoi. O vínculo social foi fundado sobre a elevada, nobre e reabilitante caridade fraterna: o milagre social, foi criado apenas por um sublime e ardente sentimento de piedade e de amor

E que importa a Ettore Ciccotti ser deputado de Vicaria? O homem, nele, é superior a este encargo mantido, frequentemente por gente vil ou estúpida. A beleza de sua alma não possui resquícios de ambição pueril: não é um arrivista: o socialismo não serviu para que ele ascendesse: por inúmeras outras forças intelectuais e morais, que possui, ele teria ascendido. E não foi sempre socialista: e a história de seu caminho para Damasco $^{72}$, todo mérito seu, é o romance de um espírito íntegro e puro que de repente se rebela contra a infâmia social, em todos os níveis, infâmia que não o atinge, mas que está a seu redor: é a rebelião obscura e impetuosa de um altruísta.

Seja, seja, sempre o pai do povo de Vicaria Ettore Ciccotti! Que este povo que ele amou e que o ama dele não se esqueça: não o abandone de novo a sua sorte triste e cruel: que leve a luz da palavra, a beleza do exemplo, a eficácia da ação àquelas pessoas desventuradas que são humanas, cristãs, possuem os sinais da inteligência e do sentimento, na pessoa. Para isso, não precisa ser deputado. E, talvez, amanhã, Ettore Ciccotti será de novo, se o jovem patrício que ocupou o seu posto, não se decida, e talvez seja capaz de fazê-lo, tornar-se, de Ettore Ciccotti, estudioso, cooperador, irmão, no bairro Vicaria. O título de pai, é tão belo, é tão digno! Não há quem o pronuncie sem se comover: e na boca do povo, isso significa oração e bênção.

Nápoles, Novembro de 1904

\footnotetext{
${ }^{72}$ No texto de partida, via di Damasco, em referência à conversão de São Paulo, que se converteu ao cristianismo a caminho de Damasco.
} 


\section{UMA MULHER}

Já provaram o sutil e melancólico prazer, cheio de secretas surpresas e íntimas vibrações, de rebuscar entre os velhos retratos em um antigo álbum do qual há anos, não se retirava o fecho, uma pasta empoeirada da qual, há tanto tempo não se soltavam os laços? Já fixaram os olhos nos pálidos retratos de pessoas já mortas, já que, misteriosamente, todos os retratos dos mortos parecem desbotados? Rostos de mortos, rostos de pessoas desaparecidas, que, não voltaremos mais a ver, rostos de criaturas que, talvez nos amaram e que amamos pouco, talvez, e, que não amaram a tempo, talvez, rostos já consumidos pela tristeza ou florescentes de uma beleza quase intangível, rostos de velhos retratos, de pessoas que levaram embora uma parte de nosso coração, que apagaram a luz da alma, talvez, ou que, talvez, deixaram uma profunda e indelével recordação! Este sutil prazer de tocar com os dedos trépidos, os antigos retratos, da melancolia nos faz passar ao sofrimento: e quando, perturbados pelos fantasmas que evocamos, deixamos cair o álbum e fechamos a pasta, ondas de amargura continuam a flutuar no nosso sangue. Oh passado, apenas tu és verdadeiro! Tenho diante de mim um retrato um pouco antigo, de uma mulher: de uma senhora: é uma fotografia, que deve ter cerca de trinta anos, talvez, e que foi dada à mulher que dignamente, mais e venerei no mundo, a minha mãe.

Este retrato é de Teresa Ravaschieri ${ }^{73}$ e já naquele tempo em que foi amigavelmente presenteado, não era um retrato novo: vejo um rosto oval, sereno, sorridente, eminentemente juvenil; escuros e espessos cabelos negros, onde se apoia um diadema precioso: um vestido de festa que deixa à mostra o colo e os ombros esculturais, adornados com um riquíssimo colar: um rosto de camafeu, enfim, onde a pureza das linhas é animada pela expressão mais espiritual na luz dos belos olhos grandes e límpidos, no sorriso da bela boca, em toda a tranquilidade viva e fresca da fisionomia. O precioso retrato, portanto, mostra uma Teresa Ravaschieri em toda a plenitude da sua beleza e da sua graça feminina, quando a sua pessoa e o seu intelecto, o seu fascínio e a sua cultura atraíam a ela as homenagens devotas de italianos e de estrangeiros, quando o seu nome, ilustre para todos os seus antepassados, ilustre para seu avô, para seu pai, representava, em Nápoles, a verdadeira grande dama pela qual a alta sociedade napolitana, de então, era verdadeiramente alta. Precioso retrato que fez,

\footnotetext{
${ }^{73}$ Teresa Filangieri Fieschi Ravaschieri: Filantropa e escritora italiana (Napoli,1826-Napoli, 1903)
} 
que faz estremecer profundamente minha alma, que exalta, em um sonho de beleza e de bondade a minha fantasia e que dá ao meu coração, que não sabe esquecer, com um novo ímpeto a inconsolável lembrança, o de não ter visto, ano passado, extinguir-se a grande alma de Teresa Ravaschieri, de não ter podido, de luto, seguir, a pé, o seu cortejo fúnebre, de não ter podido beijar, chorando, a pedra marmórea que fecha seu sepulcro, como se ela fosse minha segunda mãe.

\section{$*$ \\ $* *$}

Qual mulher, algum dia, se igualará a ela? Quem ousará fazer o que ela fez? A soma das suas virtudes morais não é, talvez, tão grande quanto a das suas obras, não revelou todo o bem que ela pensou e sentiu? Quem já realizou um alto sonho de amor como ela? Quem alcançou um objetivo mais alto, mais nobre e mais puro, apenas com a vontade de realizar o bem? Onde não chegou seu desejo de caridade e onde não pôs seu testemunho de seu desejo satisfeito? O que ela não invocou sobre os pobres, sobre os aflitos, sobre os desamparados e qual bálsamo, para ela, não curou as cruéis feridas deles? Flutuam as belas recordações na minha mente e Teresa Ravaschieri me aparece como em uma selva de vívidas rosas perfumadas, e cada uma delas é um benefício, cada uma delas é uma caridade, cada uma delas é um ato de amor! Quantas vezes, no seu contato espiritual, senti revigorar-se minha enfraquecida fé cristã: já que ela era uma cristã perfeita, humilde, lúcida, terna sem afetação, esperançosa sem ousadia, confiante sem hesitação. Um dia, falávamos da Galilea, e do grande lago de Genesareth, onde Cristo acalmou a tempestade, e da montanha de Hattine, onde ele pronunciou o inesquecível sermão: e os olhos de Teresa Ravaschieri tornaram-se sonhadores e como em um sonho, ela me disse: sabe, tenho certeza de que se tivesse tido a sorte de viver lá, naquela época, teria seguido Jesus, em todos os lugares, como as Marias: e era verdadeiro, pois a sua alma ardente era apostólica, pois ela amava difundir a sua chama vívida, e geradora de vida do espírito! Quantas vezes ela me chamou para comunicarme uma de suas ideias íntegras, oportunas e generosas e eu, como os outros seres miseráveis, com as mãos e as almas tomadas pela incerteza e pela fraqueza, como tantos outros infelizes que, devastados pela dúvida, temem abandonar-se às empresas audazes, arriscadas e magníficas, colocava miseravelmente, objeções mesquinhas sempre temendo pelas complicações, nas quais ela comprometia a sua saúde, a sua paz, o seu tempo. Ela balançava a cabeça, sorria: retomava o seu discurso, no qual todo o seu projeto ideal de socorro, de subsídios, de proteção surgia magicamente colorido: e de 
repente, eu, como os outros, éramos atingidos pela graça, e diante dela nos sentíamos surpresos e fracos, e sentíamos que um desejo elevado e belo nos arrastava e éramos envolvidos em uma onda de bem que, dela emanava, que nos tornava capazes de cem coisas mais fortes do que nós, que nos dava a força de servi-la, Teresa Ravaschieri, nos seus milagres de ternura que nos impelia a segui-la, como discípulos de um Mestre divino. Ah Ela, sim, teria seguido, com a cabeça envolta no manto e os pés nus nas sandálias, Jesus, pelo monte Tabor, pelas planícies de Elsdrelon e pelos penhascos da Samaria, até Jerusalém, até o Calvário, além do Calvário: mas diante de sua palavra de piedade, de seu sentimento de amor, desta luz constante e geradora de bem que emanava dela, todos nós a teríamos seguido, onde ela quisesse, com ela, onde grassasse a mais cruel epidemia, onde jazessem os mortos de um cataclismo, onde estrilassem gritos de guerra. Quem, quem nos dirá, como Teresa Ravaschieri dizia, a palavra que desperta a alma e que a eleva à devoção suprema? Quem mais, quem mais nos indicará, com a mão branca e olho cintilante, a via do sacrifício sublime? Ah, estamos sós, frios, tristes e desconfiados de qualquer coisa e de qualquer pessoa, e nunca mais, ouviremos a voz que nos dava a força de viver, a energia de viver pelos outros, a abnegação de viver por todos os outros, todos, amigos, indiferentes, estranhos, inimigos. Não morreu uma mulher, no ano passado, em dez de setembro: extinguiu-se a mais incomparável força espiritual: desapareceu a melhor parte de nós, aquela que incluía as três virtudes da alma, a caridade, a fé, a esperança: perdemos, com ela o segredo da nossa vida de cristãos diligentes e de criaturas humanas dignas deste nome, o senso da ternura fraternal, extinguiu-se, em nós, pois ela, a Evocadora, a Animadora de todas as fraternais ternuras, extinguiu-se!

$$
\begin{aligned}
& * \\
& * *
\end{aligned}
$$

É justo que, hoje, em um templo, os mais importantes cidadãos napolitanos e as mais piedosas mulheres e todos os mais conhecidos que amaram e admiraram Teresa Ravaschieri, reúnam-se para homenagear a sua memória e para pedir paz a ela. Tais celebrações fúnebres solenes, são muito belas, e também comoventes. Mas quando penso que, lá, deverão entrar todos aqueles que ela ajudou, aquele templo será pequeno, muito pequeno, infinitamente pequeno: a multidão dos pobres, dos infelizes, dos doentes, dos abandonados, aos quais ela concedeu digna esmola, de recuperação, de saúde recuperada, de cuidados maternais, a multidão, à qual ela deu seu amor e sua fortuna, seu tempo e sua alma, a multidão à qual ela se doou, em um longo e entusiasta 
sacrifício, é imensa. Nenhum templo poderia abrigar a todos e cada um deles, pois os anônimos, os desamparados não esquecem, certamente, a cada vez que seu espírito se difunde na oração, lembrará o nome de Teresa Ravaschieri. E é, talvez, mais justo pedir a ela, que do seu eterno repouso reze pela nossa paz: muito mais justo que nós, abatidos, feridos, cansados, oprimidos, sem um guia na existência, peçamos paz a ela. Ela lutou e venceu, em nome de Deus e em nome da virtude de amor que acolhe toda a humanidade. Muito antes de morrer, ela já estava em paz. Ela havia dito a Deus as palavras extremas, muito antes de morrer: e havia recebido o dom da paz. É para o nosso barco em perigo, em uma grande tempestade, à noite, que precisa pedir ajuda de um espírito que ora, na beatitude celeste: é para o nosso naufrágio que a alma eleita deve dar ajuda, do misterioso mundo das almas. A grande alma estava habituada aos milagres, pela força da oração, e da bondade. Rezemos para que Ela continue!

Nápoles, outono de 1904 


\section{BIBLIOGRAFIA}

ARMELlinI, G.; COLOMBO, A. La letteratura italiana. Bologna: Zanichelli, 1999, vol. 6 e 7 .

AUBERT, F. H. As (in)fidelidades da tradução. Servidões e autonomia do tradutor. Campinas: UNICAMP, 1993.

AUBERT, F. H. Modalidades de tradução: teoria e resultados. TradTerm (São Paulo) 5.1, 99-128, 1998.

BARBERI SQUAROTTI, G. Storia della civiltà letteraria italiana. Torino: Unione Tipografica Torinese, 1990.

BIANCO, G.; MANCINO, N. Giustino Fortunato: a centocinquant'anni dalla nascita. Roma: Senato della Repubblica, 1999.

BONA, F. D. Nápoles, macarrão e literatura. Revista Top View Curitiba, p. 116 - 120, 10 jul. 2009.

BRESCIANNI, M. S. Londres e Paris no século XIX. O espetáculo da pobreza. São Paulo: Brasiliense, 1982.

CALICE, S. "Brigantaggio post-unitario". In: Rionero e il Vulture: alla ricerca dell'identità perduta, una guida. Rionero in Vulture: Calice Editore, 2000.

CARBONE, L. R. Cara Matilde: la Serao, la scrittura e la vita. Kairós, 2008.

CAVALHEIRO, E. Maravilhas do Conto italiano. Introdução e notas de Edgard Cavalheiro; Organização Diaulas Riedel; Seleção: Aldo Bagnotti. São Paulo: Editora Cultrix, 1963.

CIANO, A. I Savoia e il massacro del Sud. Roma: Grandmelò, 1996.

CROCE, B. La letteratura della nuova Italia: saggi critici. Volume Terzo. Bari: Laterza, 1943.

DANIELE, V. “Lynn, Lombroso e l'intelligenza dei meridionali” In: StrumentiRes Rivista online della Fondazione Res Anno II - n 3 - Aprile 2010.

DE MARTINO, Ernesto. Sud e Magia. Milão: Einaudi, 1982. 
ECO, Umberto. Dire quasi la stessa cosa. Esperienze di traduzione. Roma: Bompiani, 2003.

FABRIS, Mariarosaria. Cenas da vida siciliana: Giovanni Verga. São Paulo: Berlendis \& Vertecchia, 2001.

FERRONI, G.; CORTElESSA, A.; PANTANI, I.; TATTI, S. Storia e testi della letteratura italiana. La nuova Italia (1861-1910). Milão: Mondadori Università, 2008.

GISOLFI, Anthony M. The essential Matilde Serao. Nova York: Las Americas Publishing Company, 1968.

GIUDICE, A.; BRUNI, G. Problemi e scrittori della letteratura italiana (Ottocento). Torino: Paravia, 1988.

GRAMSCI, Antonio. La questione merdionale. Roma: Editori Riuniti, 1966.

LIMA DA COSTA, K.; RIBEIRO PRESTES, R.; RODRIGUES DE MOURA, G. A reforma urbana do Rio de Janeiro nas crônicas de João do Rio e Lima Barreto. Revista Historiador Número 05. Ano 05. Dezembro de 2012, pp 59-66. Acessado em 20/07/2014. Disponível em: http://www.historialivre.com/revistahistoriador

LUPERINI, R; CATALDI, P.; MARCHIANI, L. La scrittura e l'interpretazione. Storia e Antologia della Letteratura italiana nel quadro della civiltà europea. Dal Naturalismo alle vanguardie. (1861-1925). Firenze: Palumbo, 1997.

PALERMO, A. "Mezzo Secolo di Letteratura a Napoli” in BARBERI SQUAROTTI, G. Storia della civiltà letteraria italiana. Torino: Unione Tipografica Torinese, 1990.

PELLINI, P. Naturalismo e Verismo: Zola, Verga e la poetica del romanzo. Firenze: Le Monnier Università, 2010.

SALVEMINI, G. Scritti sulla questione meridionale (1896-1955). Torino: Einaudi, 1955.

SERAO, M. All'erta, sentinella! (Terno secco-Trenta per cento-O Giovannino o la morte-Racconti napoletani. Milão: Casa Editrice Baldini e Castoldi, 1914.

SERAO, M. Fantasia. Milão: Garzanti, 1946. 
SERAO, M. Unmarried women: stories. (trad. Paula Paige; prefácio Mary Ann McDonald Carolan ). Chicago: Northwestern University Press, 2007.

SERAO, Matilde. Il Ventre di Napoli. Edizione integrale a cura di Patricia Bianchi e con uno scritto di Giuseppe Montesano. Cava de’ Tirreni: Avagliano Editore, 2008.

SNYDER, J. R. - A Study of Truth and Suffering: Matilde Serao's Early Writings on Naples. California Italian Studies 3(1), 2012.

http://www.escholarship.org/uc/item/5t84t40h\#page-6 Acessado em 20/05/2013

TROTTA, D. - La via della penna e dell'ago. Matilde Serao tra giornalismo e letteratura. Nápoles: Liguori, 2008.

VIEIRA, Marcilio M. - Para um estudo das influências fonológicas do italiano no português falado na cidade de São Paulo. Dissertação de Mestrado, USP, 2011.

ZOLA, Émile. O ventre de Paris. São Paulo: Cia. Brasil Editora, 1956.

SOARES DE OLIVEIRA SOBRINHO, Afonso. São Paulo e a Ideologia Higienista entre os séculos XIX e XX: a utopia da civilidade. Sociologias, 2013, 15 (Janeiro Abril). 〈http://www.redalyc.org/articulo.oa?id=86826041009> Acessado em: 16 / 07 / 2014

Dicionários

TRECCANI. L'enciclopledia italiana. www.treccani.it acessado em 27/01/2015

ZINGARELLI. Vocabolario della língua italiana. Bolonha: Nicola Zanichelli Editore, 1954. 
Il ventre di Napoli

\section{Alla baronessa Giulia de Rothachild \\ Pavillon de Pregny \\ GINEVRA}

Mia signora e amica,

Voi avete amato e Voi seguitate ad amar Napoli, con cuore ardente, con mente illuminata e alta: e il desiderio di bene che Voi nutrite, per la città mirabile, è parte viva di tutto il bene, che è nel Vostro spirito. Solo a Voi, dunque, io voglio dedicare questo libro di tenerezza, di pietà e di tristezza per Napoli.

E Voi vogliate bene all'amica Vostra

Matilde Serao. 
Questo libro è stato scritto in tre epoche diverse.

La prima parte, nel 1884, quando in un paese lontano, mi giungeva da Napoli tutto il senso di orrore, di terrore, di pietà, per il flagello che l'attraversava, seminando il morbo e la morte: e il dolore, l'ansia, l'affanno che dominano, in chi scrive, ogni cura, d'arte, dicano quanto dovette soffrire profondamente, allora, il mio cuore di napoletana.

La seconda parte, è scritta venti anni dopo, cioè solo due anni fa, e si riannoda alla prima,con un sentimento più tranquillo, ma, ahimè, più sfiduciato, più scettico che un miglior avvenire sociale e civile, possa esser mai assicurato al popolo napoletano, di cui chi scrive si onora e si gloria di esser fraterna emanazione.

La terza parte è di ieri, è di oggi: nè io debbo chiarirla, poichè essa è come le altre: espressione di un cuore sincero, di un'anima sincera: espressione tenera e dolente: espressione nostalgica e triste di un ideale di giustizia e di pietà, che discenda sovra il popolo napoletano e lo elevi o lo esalti!

NAPOLI, autunno 1905

\section{Matilde Serao}




\section{Vent'anni fa}

\section{BISOGNA SVENTRARE NAPOLI}

Efficace la frase, Voi non lo conoscevate, onorevole Depretis, il ventre di Napoli. Avevate torto, perchè voi siete il Governo e il Governo deve saper tutto. Non sono fatte pel Governo, certamente, le descrizioncelle colorite di cronisti con intenzioni letterarie, che parlano della via Caracciolo, del mare glauco, del cielo di cobalto, delle signore incantevoli e dei vapori violetti del tramonto: tutta questa rettorichetta a base di golfo e di colline fiorite, di cui noi abbiamo già fatto e oggi continuiamo a fare ammenda onorevole, inginocchiati umilmente innanzi alla patria che soffre; tutta questa minuta e facile letteratura frammentaria, serve per quella parte di pubblico che non vuole essere seccata per racconti di miserie. Ma il governo doveva sapere l'altra parte; il governo a cui arriva la statistica della mortalità e quella dei delitti; il governo a cui arrivano i rapporti dei prefetti, dei questori, degli ispettori di polizia, dei delegati; il governo a cui arrivano i rapporti dei direttori delle carceri; il governo che sa tutto: quanta carne si consuma in un giorno e quanto vino si beve in un anno, in un paese; quante femmine disgraziate, diciamo così, vi esistano, e quanti ammoniti siano i loro amanti di cuore, quanti mendichi non possano entrare nelle opere pie e quanti vagabondi dormano in istrada, la notte; quanti nullatenenti e quanti commercianti vi sieno; quanto renda il dazio consumo, quanto la fondiaria, per quanto s'impegni al Monte di Pietà e quanto renda il lotto. Quest'altra parte, questo ventre di Napoli, se non lo conosce il Governo, chi lo deve conoscere? E se non servono a dirvi tutto, a che sono buoni tutti questi impiegati alti e bassi, a che questo immenso ingranaggio burocratico che ci costa tanto? E, se voi non siete la intelligenza suprema del paese che tutto conosce e a tutto provvede, perchè siete ministro?

$$
\begin{gathered}
* \\
* *
\end{gathered}
$$

Vi avranno fatto vedere una, due, tre strade dei quartieri bassi e ne avrete avuto orrore. Ma non avete visto tutto; i napoletani istessi che vi conducevano, non conoscono tutti i quartieri bassi. La via dei Mercanti, l'avete percorsa tutta? 
Sarà larga quattro metri, tanto che le carrozze non vi possono passare, ed è sinuosa, si torce come un budello: le case altissime la immergono, durante le più belle giornate, in una luce scialba e morta: nel mezzo della via il ruscello è nero, fetido, non si muove, impantanato, è fatto di liscivia e di saponata lurida, di acqua di maccheroni e di acqua di minestra, una miscela fetente che imputridisce. In questa strada dei Mercanti, che è una delle principali del quartiere Porto, v'è di tutto: botteghe oscure, dove si agitano delle ombre, a vendere di tutto, agenzie di pegni, banchi lotto; e ogni tanto un portoncino nero, ogni tanto un angiporto fangoso, ogni tanto un friggitore, da cui esce il fetore dell'olio cattivo, ogni tanto un salumaio, dalla cui bottega esce un puzzo di formaggio che fermenta e di lardo fradicio.

Da questa via partono tante altre viottole, che portano i nomi delle arti: la Zabatteria, i Coltellai, gli Spadari, i Taffettanari, i Materassari, e via di seguito. Sono, queste viottole - questa è la sola differenza - molto più strette dei Mercanti, ma egualmente sporche e oscure; e ognuna puzza in modo diverso: di cuoio vecchio, di piombo fuso, di acido nitrico, di acido solforico.

Varie strade conducono dall'alto al quartiere di Porto: sono ripidissime, strette, mal selciate. La via di Mezzocannone è popolata tutta di tintori: in fondo a ogni bottega bruna, arde un fuoco vivo sotto una grossa caldaia nera, dove gli uomini seminudi agitano una miscela fumante; sulla porta si asciugano dei cenci rossi e violetti; sulle selci disgiunte, cola sempre una feccia di tintura multicolore. Un'altra strada, le così dette Gradelle di Santa Barbara, ha anche la sua originalità: da una parte e dall'altra abitano femmine disgraziate, che ne hanno fatto un loro dominio, e, per ozio di infelici disoccupate, nel giorno, e per cupo odio contro l'uomo, buttano dalla finestra, su chi passa, buccie di fichi, di cocomero, spazzatura, torsoli di spighe. e tutto resta, su questi gradini, così che la gente pulita non osa passarvi più. Vi è un'altra strada, che dietro l'educandato di San Marcellino, conduce a Portanova, dove i Mercanti finiscono e cominciano i Lanzieri: veramente non è una strada, è un angiporto, una specie di canale nero, che passa sotto due archi e dove pare raccolta tutta la immondizia di un villaggio africano. Ivi, a un certo punto, non si può procedere oltre: il terreno è lubrico e lo stomaco spasima.

In sezione Vicaria, vi siete stato? 
Sopra tutte le strade che la traversano, una sola è pulita, la via del Duomo: tutte le altre sono rappresentazioni della vecchia Napoli, affogate, brune, con le case puntellate, che cadono per vecchiaia. Vi è un vicolo del Sole, detto così perchè il sole non vi entra mai; vi è un vicolo del Settimo Cielo, appunto per l'altitudine di una strisciolina di cielo, che apparisce fra le altissime e antiche case. Attorno alla piazzetta dei SS. Apostoli vi sono tre o quattro stradette; Grotta della Marra, Santa Maria a Vertecoeli, vicolo della Campana, dove vive una popolazione magra e pallida, appestata dalla fabbrica di tabacco che è lì, appestata dalla propria sudiceria; e tutti i dintorni di Castelcapuano, di questa grande e storica Vicaria, sembrano proprio il suo ambiente, vale a dire putridume materiale e morale, su cui sorge l'estremo portato di questa società povera e necessariamente corrotta: la galera.

La sezione Mercato? Ah, già: quella storica, dove Masaniello ha fatto la rivoluzione, dove hanno tagliato il capo a Corradino di Svevia; sì, sì, ne hanno parlato drammaturghi e poeti. Se ne traversa un lembo, venendo in carrozza, dalla Ferrovia, ma si esce subito alla Marina. Al diavolo la poesia e il dramma! In sezione Mercato, niuna strada è pulita; pare che da anni non ci passi mai lo spazzino; ed è forse la sporcizia di un giorno.

Ivi è il Lavinaio, la grande fonte, dove si lavano i cenci luridi della vecchia e povera Napoli: il Lavinaio, che è il grande ruscello, dove il luridume viene a detergersi superficialmente; tanto che per insultare bonariamente un napoletano, sul proprio napoletanesimo, gli si dice. - Sei proprio del Lavinaio. Nella sezione Mercato, vi sono i sette vicoli della Duchesca, in uno dei quali, ho letto un dispaccio, vi sono stati in un'ora trenta casi; vi è il vicolo del Cavalcatoio; vi è il vicolo di Sant'Arcangelo a Baiano. Io sono una donna e non posso dirvi che sieno queste strade, poichè ivi l'abbiezione diventa così profonda, così miseranda, la natura umana si degrada talmente, che vengono alla faccia le fiamme della vergogna.

\section{$*$}

Sventrare Napoli? Credete che basterà? Vi lusingate che basteranno tre, quattro strade, attraverso i quartieri popolari, per salvarli? Vedrete, vedrete, quando gli studi, per questa santa opera di redenzione, saranno compiuti, quale verità fulgidissima risulterà: bisogna rifare. Voi non potrete sicuramente lasciare in piedi le case che sono lesionate dalla umidità, dove al pianterreno vi è il fango e all'ultimo piano si brucia nell'estate e si gela nell'inverno; dove le scale sono ricettacoli d'immondizie; nei cui 
pozzi, da cui si attinge acqua così penosamente, vanno a cadere tutti i rifiuti umani e tutti gli animali morti; e che hanno tutto un pot-bouille, una cosidetta vinella, una corticina interna in cui le serve buttano tutto; il cui sistema di latrine, quando ci sono, resiste a qualunque disinfezione.

Voi non potrete lasciare in piedi le case, nelle cui piccole stanze sono agglomerate mai meno di quattro persone, dove vi sono galline e piccioni, gatti sfiancati e cani lebbrosi; case in cui si cucina in uno stambugio, si mangia nella stanza da letto e si muore nella medesima stanza, dove altri dormono e mangiano, case, i cui sottoscala, pure abitati da gente umana, rassomigliano agli antichi, ora aboliti, carceri criminali della Vicaria, sotto il livello del suolo.

Voi non potrete sicuramente lasciare in piedi i cavalcavia che congiungono le case; nè quelle ignobili costruzioni di legno che si sospendono a certe muraglie di case, nè quei portoncini angusti, nè vicoli ciechi, nè quegli angiporti, nè quei supportici; voi non potrete lasciare in piedi i fondaci.

Voi non potrete lasciare in piedi certe case dove al primo piano è un'agenzia di pegni, al secondo si affittano camere a studenti, al terzo si fabbricano i fuochi artificiali: certe altre dove al pianterreno vi è un bigliardo, al primo piano un albergo dove si pagano tre soldi per notte, al secondo una raccolta di poverette, al terzo un deposito di cenci.

Per distruggere la corruzione materiale e quella morale, per rifare la salute e la coscienza a quella povera gente, per insegnare loro come si vive - essi sanno morire, come avete visto! - per dir loro che essi sono fratelli nostri, che noi li amiamo efficacemente, che vogliamo salvarli, non basta sventrare Napoli: bisogna quasi tutta rifarla.

\section{II}

\section{QUELLO CHE GUADAGNANO}

Eppure la gente che abita in questi quattro quartieri popolari, senz'aria, senza luce, senza igiene, diguazzando nei ruscelli neri, scavalcando monti d'immondizie, respirando miasmi e bevendo un'acqua corrotta, non è una gente bestiale, selvaggia, oziosa; non è tetra nella fede, non è cupa nel vizio, non è collerica nella sventura. Questo popolo, per sua naturale gentilezza, ama le case bianche e le colline: onde il giorno di Ognissanti, quando da Napoli, tutta la gente buona porta corone ai morti, sul colle di Poggioreale, in quel cimitero pieno di fiori, di uccelli, di profumi, di marmi, vi è 
chi l'ha intesa gentilmente esclamare: o Gesù, vurria murì, pe sta ccà! Questo popolo ama i colori allegri, esso che adorna di nappe e nappine i cavalli dei carri,che si adorna di pennacchietti multicolori nei giorni di festa, che porta i fazzoletti scarlatti al collo, che mette un pomodoro sopra un sacco di farina, per ottenere un effetto pittorico e che ha creato un monumento di ottoni scintillanti, di legni dipinti, di limoni fragranti, di bicchieri e di bottiglie, un monumentino che è una festa degli occhi: il banco dell'acquaiuolo.

Questo popolo che ama la musica e la fa, che canta così amorosamente e malinconiosamente, tanto che le sue canzoni dànno uno struggimento al core e sono la più invincibile nostalgia per colui che è lontano, ha una sentimentalità espansiva, che si diffonde nell'armonia musicale.

Non è dunque una razza di animali, che si compiace del suo fango; non è dunque una razza inferiore che presceglie l'orrido fra il brutto e cerca volenterosa il sudiciume; non si merita la sorte che le cose gl'impongono; saprebbe apprezzare la civiltà, visto che quella pochina elargitagli, se l'ha subito assimilata; meriterebbe di esser felice.

$$
\begin{gathered}
* \\
* *
\end{gathered}
$$

Abita laggiù, per forza. È la miseria sua, costituzionale, organica, così intensa, così profonda, che cento Opere Pie non arrivano a debellare, che la carità privata, fluidissima, non arriva a vincere; non la miseria dell'ozioso, badate bene, ma la miseria di colui che fatica quattordici ore al giorno.

Questo lavoratore, quest'operaio non può pagare un affitto di casa, che superi le quindici lire il mese: e deve essere un operaio fortunato, vi è chi ne paga dieci, chi ne paga sette, chi ne paga cinque; questi ultimi formano la grande massa del popolo. Anni fa, una compagnia cooperativa edificò, verso Capodimonte, un falansterio di case operaie, chiare, pulite, strettine, ma infine igieniche: per quanto restringesse i prezzi, non potette dare i suoi appartamentini, a meno di trentaquattro lire al mese.

Nessuno operaio vi andò.

Vi andarono degli impiegati con le famiglie, qualche pensionato, gli sposetti poveri, insomma una mezza borghesia che vuol nascondere la sua miseria e avere la scaletta di marmo.

Quel grandissimo edificio resta lì a far prova della miseria napoletana: anzi, gli scrupolosi e borghesi che vi abitano, punti nel loro presuntuoso amor proprio, da coloro 
che li accusavano di abitare le case operaie, hanno fatto dipingere a grandi caratteri questa scritta sull'ingresso maggiore:

le case della Cooperativa non sono case operaie. Iscrizione crudele e superba.

Trentaquattro lire? Queste trentaquattro lire un lavoratore napoletano le guadagna in un mese: chi porta una lira di giornata a casa, si stima felice.

Le mercedi sono scarsissime, in quasi tutte le professioni, in tutt'i mestieri. Napoli è il paese dove meno costa l'opera tipografica; tutti lo sanno: gli operai tipografi sono pagati un terzo meno degli altri paesi. Quelli che guadagnano cinque lire a Milano, quattro a Roma, ne guadagnano due a Napoli, tanto che è in questo benedetto e infelice paese, dove più facilmente nascono e vivono certi giornaletti poverissimi, che altrove non potrebbero pubblicare neppure tre numeri. I sarti, i calzolai, i muratori, i falegnami sono pagati nella medesima misura; una lira, venticinque soldi, al più, trenta soldi al giorno per dodici ore di lavoro, talvolta penosissimo. I tagliatori di guanti guadagnano novanta centesimi al giorno. E notate che la gioventù elegante di Napoli, è la meglio vestita d'Italia: che a Napoli si fanno le più belle scarpe e i più bei mobili economici; notate che Napoli produce i migliori guanti. Altri mestieri inferiori stabiliscono la mercede a settantacinque centesimi, a dodici soldi, a dieci soldi. Per questo essi non possono pagare più di cinque, sette, dieci lire il mese di pigione e come la miseria incombe, la donna, la moglie, la madre, tutte quelle che hanno già molto partorito, che hanno allattato, tutte quelle che dovrebbero lavorare in casa, cercano lavoro, fuori.

Fortunate quelle che trovano un posto alla Fabbrica del tabacco, che sanno lavorare e arrivano ad allogarsi, come sarte, come modiste, come fioraie! La mercede è miserissima, quindici lire, diciassette, venti lire il mese; pure sembra loro fortuna. Ma sono poche: tutto il resto della immensa classe povera femminile, si dà alla domesticità.

La serva napoletana si alloga per dieci lire il mese, senza pranzo: alla mattina fa due o tre miglia di cammino, dalla casa sua alla casa dei suoi padroni, scende le scale quaranta volte al giorno, cava dal pozzo profondo venti secchi di acqua, compie le fatiche più estenuanti, non mangia per tutta la giornata e alla sera si trascina a casa sua, come un'ombra affranta. Ve ne sono di quelle che pigliano due mezzi servizi, a sei lire l'uno e corrono continuamente da una casa all'altra, continuamente rimproverate per le tardanze. Ne ho conosciuta una, io, si chiamava Annarella, faceva tre case al giorno, a cinque lire: alla sera era inebetita, non mangiava, morta dalla fatica, talvolta non si svestiva, per addormentarsi subito. 
Queste serve trovano anche il tempo di dar latte a un bimbo, di far la calza, ma sono esseri mostruosi, la pietà è uguale alla ripugnanza che ispirano. Hanno trent'anni e ne dimostrano cinquanta, sono curve, hanno perso i capelli, hanno i denti gialli e neri, camminano come sciancate, portano un vestito quattro anni, un grembiule sei mesi.

Non si lamentano, non piangono: vanno a morire, prima di quarant'anni, all'ospedale, di perniciosa, di polmonite, di qualche orrenda malattia. Quante ne avrà portate via il colera!

E tutti gli altri mestieri ambulanti femminili, lavandaie, pettinatrici, stiratrici a giornata, venditrici di spassatiempo, rimpagliatrici di seggiole (mpagliaseggie), mestieri che le espongono a tutte le intemperie, a tutti gli accidenti, a una quantità di malattie, mestieri pesanti o nauseanti, non fanno guadagnare a quelle disgraziate più di dieci soldi, quindici soldi al giorno. Quando guadagnano una lira, le miserelle, fanno economia e si maritano.

Sono brutte, è vero: si trascurano, è verissimo: fanno schifo, talvolta. Ma chi tanto ama la plastica, dovrebbe entrare nel segreto di quelle esistenze, che sono un poema di martirio quotidiano, di sacrifici incalcolabili, di fatiche sopportate senza mormorare. Gioventù, bellezza, vestiti? Ebbero un minuto di bellezza e di gioventù, furono, amate, si sono maritate: dopo, il marito e la miseria, il lavoro e le busse, il travaglio e la fame. Hanno i bimbi e debbono abbandonarli, il più piccolo affidato alla sorellina, e come tutte le altre madri, temono le carrozze, il fuoco, i cani, le cadute.

Sono sempre inquiete, agitate, mentre servono.

Me ne rammento una: aveva tre figli, un piccolino, specialmente, bellissimo. Il bimbo aveva già due anni ed essa gli dava ancora il latte, non aveva altro da dargli da mangiare: questo bimbetto l'aspettava, ogni sera, seduto sullo scalino del basso. Diceva il medico dell'assistenza pubblica: «Levagli il latte, chè ti si ammala.» Ella chinava il capo: non poteva levargli il latte. Si ammalò di tifo, il bimbo; le morì. Ella mondava le patate, in una cucina, e si lamentava, sottovoce: «figlio mio, figlio mio, io t'aveva da accidere, io t'aveva da fa murì! O che mamma cana che ssò stata! Figlio mio, e chi m'aspetta cchiù, la sera, mocc'a porta?»

Il lavoro dei fanciulli? Ahimè, le madri sono molto contente, quando un cocchiere signorile vuol prendere per mozzo un fanciullo di dodici anni, dandogli solo da mangiare; sono molto contente, quando un mastro di bottega lo piglia, facendolo lavorare come un cane e dandogli solo la minestra, la sera; la pietosa madre gli dà un soldo per la colazione, la mattina. 
Le sarte, le modiste, le fioraie, le bustaie, prendono per apprendiste delle fanciullette dodicenni, che sono, in realtà, delle piccole serve e che guadagnano cinque soldi la settimana. Ma, per lo più, queste creature restano a casa o nella strada, tutto il giorno.

Nelle campagne, il figlio è una gioia, è un soccorso, è una sorgente di agiatezza; in Napoli rappresenta una cura di più, una pena materna, una sorgente di lagrime e di fame.

Ascoltate un poco, quando una operaia napoletana nomina i suoi figli. Dice: le creature, e lo dice con tanta dolcezza malinconica, con tanta materna pietà, con un amore così doloroso, che vi par di conoscere tutta, acutamente, la intensità della miseria napoletana.

\section{III}

\section{QUELLO CHE MANGIANO}

Un giorno, un industriale napoletano ebbe un'idea. Sapendo che la pizza è una delle adorazioni cucinarie napoletane, sapendo che la colonia napoletana in Roma è larghissima, pensò di aprire una pizzeria in Roma. Il rame delle casseruole e dei ruoti vi luccicava, il forno vi ardeva sempre; tutte le pizze vi si trovavano: pizza al pomidoro, pizza con muzzarella e formaggio, pizza con alici e olio, pizza con olio, origano e aglio. Sulle prime la folla vi accorse, poi andò scemando.

La pizza, tolta al suo ambiente napoletano, pareva una stonatura e rappresentava una indigestione; il suo astro impallidì e tramontò, in Roma; pianta esotica, morì in questa solennità romana.

È vero, infatti: la pizza rientra nella larga categoria dei commestibili che costano un soldo, e di cui è formata la colazione o il pranzo, di moltissima parte del popolo napoletano.

Il pizzaiuolo che ha bottega, nella notte, fa un gran numero di queste schiacciate rotonde, di una pasta densa, che si brucia, ma non si cuoce, cariche di pomidoro quasi crudo, di aglio, di pepe, di origano: queste pizze in tanti settori da un soldo, sono affidate a un garzone, che le va a vendere in qualche angolo di strada, sovra un banchetto ambulante e lì resta quasi tutto il giorno, con questi settori di pizza che si gelano al freddo, che si ingialliscono al sole, mangiati dalle mosche. Vi sono anche 
delle fette di due centesimi, pei bimbi che vanno a scuola; quando la provvista è finita, il pizzaiuolo la rifornisce, sino a notte.

Vi sono anche, per la notte, dei garzoni che portano sulla testa un grande scudo convesso di stagno, entro cui stanno queste fette di pizza e girano pei vicoli e dànno un grido speciale, dicendo che la pizza ce l'hanno col pomidoro e con l'aglio, con la muzzarella e con le alici salate. Le povere donne sedute sullo scalino del basso, ne comprano e cenano, cioè pranzano, con questo soldo di pizza.

Con un soldo, la scelta è abbastanza varia, pel pranzo del popolo napoletano. Dal friggitore si ha un cartoccetto di pesciolini che si chiamano fragaglia e che sono il fondo del paniere dei pescivendoli: dallo stesso friggitore si hanno per un soldo, quattro o cinque panzarotti, vale a dire delle frittelline in cui vi è un pezzetto di carciofo, quando niuno vuol più saperne di carciofi, o un torsolino di cavolo, o un frammentino di alici. Per un soldo, una vecchia dà nove castagne allesse, denudate della prima buccia e nuotanti in un succo rossastro: in questo brodo il popolo napoletano vi bagna il pane e mangia le castagne, come seconda pietanza; per un soldo, un'altra vecchia, che si trascina dietro un calderottino in un carroccio, dà due spighe di granturco bollite. Dall'oste, per un soldo, si può comperare una porzione di scapece; la scapece è fatta di zucchetti o melanzane fritte nell'olio e poi condite con aceto, pepe, origano, formaggio, pomidoro, ed è esposta in istrada, in un grande vaso profondo, in cui sta intasata, come una conserva e da cui si taglia con un cucchiaio. Il popolo napoletano porta il suo tozzo di pane, lo divide per metà, e l'oste vi versa sopra la scapece. Dall'oste, sempre per un soldo, si compera la spiritosa: la spiritosa è fatta di fette di pastinache gialle, cotte nell'acqua e poi messe in una salsa forte di aceto, pepe, origano e peperoni. L'oste sta sulla porta e grida: addorosa, addorosa, 'a spiritosa! Come è naturale, tutta questa roba è condita in modo piccantissimo, tanto da soddisfare il più atonizzato palato meridionale.

Appena ha due soldi, il popolo napoletano compra un piatto di maccheroni cotti e conditi; tutte le strade dei quartieri popolari, hanno una di queste osterie che installano all'aria aperta le loro caldaie, dove i maccheroni bollono sempre, i tegami dove bolle il sugo di pomidoro, le montagne di cacio grattato, un cacio piccante che viene da Cotrone. Anzi tutto, quest'apparato è molto pittoresco, e dei pittori lo hanno dipinto, ed è stato da essi reso lindo e quasi elegante con l'oste che sembra un pastorello di 
Watteau; e nella collezione di fotografie napoletane, che gl'inglesi comprano, accanto alla monaca di casa, al ladruncolo di fazzoletti, alla famiglia di pidocchiosi, vi è anche il banco del maccaronaro. Questi maccheroni si vendono a piattelli di due e di tre soldi; e il popolo napoletano li chiama brevemente, dal loro prezzo: nu doie e nu tre. La porzione è piccola e il compratore litiga con l'oste, perchè vuole un po' più di sugo, un po' più di formaggio e un po' più di maccheroni.

Con due soldi si compera un pezzo di polipo bollito nell'acqua di mare, condito con peperone fortissimo: questo commercio lo fanno le donne, nella strada, con un focolaretto e una piccola pignatta; con due soldi di maruzze, si hanno le lumache, il brodo e anche un biscotto intriso nel brodo: per due soldi l'oste, da una grande padella dove friggono confusamente ritagli di grasso di maiale e pezzi di coratella, cipolline, e frammenti di seppia, cava una grossa cucchiaiata di questa miscela e la depone sul pane del compratore, badando bene a che l'unto caldo e bruno non coli per terra, che vada tutto sulla mollica, perchè il compratore ci tiene.

Appena ha tre soldi al giorno per pranzare, il buon popolo napoletano, che è corroso dalla nostalgia familiare, non va più dall'oste per comperare i commestibili cotti, pranza a casa sua, per terra, sulla soglia del basso, o sopra una sedia sfiancata.

Con quattro soldi si compone una grande insalata di pomidori crudi verdastri e di cipolle; o un'insalata di patate cotte e di barbabietole, o un'insalata di broccoli di rape; o un'insalata di citrioli freschi.

La gente agiata, quella che può disporre di otto soldi al giorno, mangia dei grandi piatti di minestra verde, indivia, foglie di cavolo, cicoria, o tutte queste erbe insieme, la cosidetta minestra maritata; o una minestra, quando ne è tempo, di zucca gialla con molto pepe; o una minestra di fagiolini verdi, conditi col pomidoro; o una minestra di patate cotte nel pomidoro.

Ma per lo più compra un rotolo di maccheroni, una pasta nerastra, e di tutte le misure e di tutte le grossezze, che è il raccogliticcio, il fondiccio confuso di tutti i cartoni di pasta, e che si chiama efficacemente monnezzaglia: e la condisce con pomidoro e formaggio.

Il popolo napoletano è goloso di frutta: ma non spende mai più di un soldo, alla volta. A Napoli, con un soldo si hanno sei peruzze un po' bacate, ma non importa: si ha 
mezzo chilo di fichi, un po' flosci dal sole: si hanno dieci o dodici di quelle piccole prugne gialle, che pare abbiano l'aspetto della febbre; si ha un grappolo di uva nera, si ha un poponcino giallo, piccolo, ammaccato, un po' fradicio; dal venditore di melloni, quelli rossi, si hanno due fette, di quelli che sono riusciti male, vale a dire biancastri.

Ha anche qualche altra golosità, il popolo napoletano: lo spassatiempo, vale a dire i semi di mellone o di popone, le fave e i ceci cotti nel forno; con un soldo si rosicchia mezza giornata, la lingua punge e lo stomaco si gonfia, come se avesse mangiato.

La massima golosità è il soffritto: dei ritagli di carne di maiale cotti con olio, pomidoro, peperone rosso, condensati, che formano una catasta rossa, bellissima all'occhio, da cui si tagliano delle fette: costano cinque soldi. In bocca, sembra dinamite.

Questionario:

Carne in umido? - Il popolo napoletano non ne mangia mai.

Carne arrosto? - Qualche volta, alla domenica, o nelle grandi feste, ma è di maiale o di agnello.

Brodo di carne? - Il popolo napoletano lo ignora.

Vino? - Alla domenica, qualche volta: l'asprino, a quattro soldi il litro, o il maraniello a cinque soldi: questo tinge di azzurro la tovaglia.

Acqua! - Sempre: e cattiva.

\section{IV}

\section{GLI ALTARINI}

Vi meravigliate degli altarini? Vi scandalizzate della piccola processione di donne scalze e scapigliate, che portano una immagine della Madonna e salmodiano? La superstizione del popolo napoletano - oh, povera gente che è vissuta così male e con tanta bonarietà, che muore in un modo così miserando, con tanta rassegnazione! - la superstizione di questo popolo ha fatto una dolorosa impressione a tutti. La credevate cessata la superstizione? Come potevate crederlo? Non vi rammentate più nulla, dunque? Nel colera del 1865 vi furono processioni e pubbliche preghiere; nel colera del 1867, più tremendo, più straziante, che veniva dopo la guerra, da tutte le parrocchie uscirono le immagini della Vergine e quelle dei santi protettori, le processioni s'incontravano per le strade, si mescolavano: era tutto un mistero mediovale 
e meridionale. Come oggi Umberto di Savoia le ha incontrate, diciassette anni fa, le ha incontrate il gran re Vittorio Emmanuele. Nella spaventosa eruzione del 1872, per tre giorni di seguito una lava ha minacciato Napoli: le popolane sono andate al Duomo per avere la testa di san Gennaro: la volevano portare in giro, per far arrestare la lava. Per un momento i nobili custodi delle reliquie e i canonici della cattedrale, non la dettero loro. Al quarto giorno non uscì il sole; una nuvola fittissima di cenere copriva Napoli, cominciava a piovere cenere, come a Pompei; le popolane, in tutti i quartieri, fecero delle processioni, piangendo, gridando in una tenebra lugubre. Nel colera del 1873, più mite certo, ma sempre vivissimo, nei quattro quartieri popolari, fu portata in processione la Madonna dell'Aiuto ai Banchi Nuovi, la Madonna di Portosalvo a Porto, il Gesù alla Colonna, della chiesa nel vicolo dell'Università. O che memoria labile abbiamo tutti!

E la vita quotidiana? Solo a guardarsi attorno, a osservare quello che accade, anche superficialmente, nessuno poteva lusingarsi che la esaltazione religiosa del popolo napoletano fosse cessata. Di questi altarini, con un paio di ceri innanzi, ve ne sono ad ogni angolo di strada, nei quartieri popolari, in certe tali feste. Li fanno i bimbi è vero: ma le madri sorvegliano, le sorellegrandi chiedono l'obolo ai passanti, un po' ridendo, un po' pregando. Per le feste più grandi, con lampioncini alla Ottino e festoni variopinti, il popolino si quota per un anno, e un vicolo la vuol vincere sull'altro: accadono risse, corrono coltellate per questa emulazione. Queste emulazioni sono pittoresche e fanno andare in estasi gli artisti - razza di egoisti - che se ne stanno immersi nella contemplazione del loro Buddha, che è l'arte. Ancora: quando una donna si salva da una grande infermità, per ringraziare Dio, scioglie il voto di andare cercando l'elemosina, per tutte le case del suo quartiere; sale, scende, con le gambe malferme, con la faccia scialba, ricevendo rifiuti secchi e porte battute in faccia. Non importa, bisogna sopportare, è il voto. Tutto quello che raccoglie, va alla chiesa. Quando un bimbo è malato, lo votano a san Francesco: quando risana, lo vestono da monacello, con una tonaca grossolana, col cordone, coi piedini nudi nei sandali, con la chierichetta rasa. Chi non ne ha incontrati, nei quartieri popolari?

Del miracolo di san Gennaro, fate le alte meraviglie? Quelle vecchie abitanti del Molo che si pretendono sue discendenti, che invadono l'altare maggiore, che non lasciano accostarsi nessuno, gridano il Credo, mentre si attende il miracolo, e ogni volta 
che ricominciano, alzano il tono, sino all'urlo, che si dimenano come ossesse, che lo gratificano di vecchio dispettoso, vecchio impertinente, faccia verde; vi stupiscono? Vi è il piede di sant'Anna che si mette sul ventre delle partorienti, che non possono procreare il figlio; vi è l'olio che arde nella lampada, innanzi al corpo di san Giacomo della Marca, nella chiesa di Santa Maria la Nuova, che fa guarire i mali di testa; vi è il Crocifisso del Carmine che ha fatto sangue dalle piaghe; vi è il bastone di san Pietro che si venera nella chiesa sotterranea di Sant'Aspreno, primo vescovo di Napoli, ai Mercanti; vi è l'acqua benedetta di San Biagio ai Librai che guarisce il mal di gola; vi sono le panelle, pagnottine di pane benedette di San Nicola di Bari, che buttate in aria, nel temporale, scampano dalle folgori. Vi sono centinaia di ossicini, di pezzetti di velo, di pezzetti di vestito, di frammenti di legno, che sono reliquie. Ogni napoletana porta al collo o sospeso alla cintura, o ha sotto il cuscino, un sacchettino di reliquie, di preghiere stampate: questo sacchettino si attacca alle fasce del bimbo, appena nato.

Credete che al napoletano basti la Madonna del Carmine? Io ho contati duecentocinquanta appellativi alla Vergine, e non sono tutti. Quattro o cinque tengono il primato. Quando una napoletana è ammalata o corre un grave pericolo, uno dei suoi, si vota a una di queste Madonne.

Dopo scioglie il voto, portandone il vestito, un abito nuovo, benedetto in chiesa, che non si deve smettere, se non quando è logoro. Per l'Addolorata il vestito è nero, coi nastri bianchi; per la Madonna del Carmine, è color pulce coi nastri bianchi; per l'Immacolata Concezione, bianco coi nastri azzurri; per la Madonna della Saletta, bianco coi nastri rosa. Quando non hanno i danari per farsi il vestito, si fanno il grembiule; quando mancano di sciogliere il voto, aspettano delle sventure in casa.

E il sacro si mescola al profano. Per aver marito, bisogna fare la novena a san Giovanni, nove sere, a mezzanotte, fuori un balcone, e pregare con certe antifone speciali. Se si ha questo coraggio, alla nona sera si vede una trave di fuoco attraversare il cielo, sopra vi danza Salomè, la ballerina maledetta: la voce che si ode, subito dopo, pronunzia il nome del marito. Anche san Pasquale è protettore delle ragazze da marito e bisogna dirgli per nove sere l'antifona: $O$ beato san Pasquale - mandatemi un marito bello, rosso, colorito - come voi tale e quale - o beato san Pasquale! - Anche san Pantaleone protegge le ragazze, ma in diverso modo: dà loro i numeri del lotto, perchè si facciano la dote, e si possano maritare. Nove sere bisogna pregarlo, a mezzanotte, in una stanza, stando sola, col balcone aperto e la porta aperta, e dopo gli Ave e i Pater dirgli questa antifona: san Pantaleone mio - per la vostra castità - per la mia verginità - 
datemi i numeri, per carità! Alla nona sera si ode un passo, è il santo che viene, si odono dei colpi, sono i numeri che dà. Alla quarta o quinta sera di questi strani riti, le ragazze sono tanto esaltate, che hanno delle allucinazioni e cadono in convulsioni. Alcune affermano di aver visto e di aver udito qualche cosa, alla nona sera: ma che mancò loro la fede e il miracolo non è riuscito.

Tutte le superstizioni sparse pel mondo, sono raccolte in Napoli e ingrandite, moltiplicate. Noi crediamo tutti quanti alla jettatura. Non parliamo dell'olio sparso, dello specchio rotto, del cucchiaio in croce col coltello, della sottana posta alla rovescia che porta sfortuna, dei soldi mercati (gobbi), dei ragni, degli scorpioni, della gallina: superstizioni vecchie, chi se ne occupa? I napoletani credono ancora alle sibille: vi è una Chiara Stella alle Cento Strade, verso il Corso Vittorio Emmanuele, vi è una siè Grazia al Vicolo Mezzocannone, famosissime; e molte altre minori. Si compensano cinquanta centesimi, due lire, cinque lire. I napoletani credono agli spiriti. Lo spirito familiare napoletano che circola in tutte le case, è il monaciello, un bimbetto vestito di bianco quando porta fortuna, vestito di rosso, quando porta sventura. Una quantità di gente mi ha affermato di averlo visto. In piena Napoli, alla salita di Santa Teresa, una bellissima palazzina non si affitta mai: per vent'anni l'ho vista chiusa, poichè è abitata dagli spiriti. Il napoletano crede agli spiriti che dànno i numeri, crede agli assistiti: gli assistiti sono una razza di gente stranissima, alcuni in buona fede, alcuni scrocconi, che mangiano poco, bevono acqua, parlano per enigmi, digiunano prima di andare a letto e hanno le visioni. Vivono alle spalle dei giuocatori: non giuocano mai. Talvolta i giuocatori delusi bastonano l'assistito, poi gli chiedono perdono. Anche i monaci hanno le visioni. Ve n'era uno famoso, a Marano presso Napoli: vi andava la gente in pellegrinaggio. Un altro giovane, era al convento di San Martino: anche famoso. Talvolta i giuocatori sequestrano il monaco, lo battono, lo torturano. Uno ne morì. Prima di spirare, pronunziò dei numeri: li giuocarono, uscirono, mezza Napoli vinse al lotto, poichè un giornale aveva riportati questi numeri.

Il popolo napoletano, specialmente le donne, crede alla stregoneria. La fattura trova apostoli ferventi: le fattucchiere, o streghe, abbondano. Una moglie vuole che suo marito, che va lontano, le resti fedele? La strega le dà una cordicella a nodi, bisogna cucirla nella fodera della giacchetta del marito. Si vuole avere l'amore di un uomo? La fattucchiera brucia una ciocca di capelli vostri, ne fa una polverina, con certi ingredienti: bisogna farla bere nel vino, all'uomo indifferente. Si vuol vincere un processo? Bisogna legare, moralmente, la lingua dell'avvocato contrario: fare quindici 
nodi ad una cordicella, chiamare il diavolo, uno scongiuro terribile. Si vuol far morire un amante infedele? Bisogna colmare un pignattino di erbe velenose, metterle a bollire innanzi alla sua porta, nell'ora di mezzanotte. Si vuol far morire una donna, una rivale? Bisogna conficcare in un limone fresco tanti spilli che formino un disegnino della sua persona, e attaccarvi un brano del vestito della rivale e infine buttare, questo limone, nel suo pozzo. La fattura ha uno sviluppo larghissimo; letteratura strana, talvolta ignobile, di scongiuri, e di preghiere; ha una classificazione, per le anime timide e per le anime audaci: ha una diffusione in tutti i quartieri; ha un soccorso per tutte le necessità sentimentali e brutali, per tutti i desideri gentili e cruenti.

Ecco tutto. Cioè, non è tutto. Esagerate venti volte quello che vi ho detto: forse, non sarete nel vero. Questo guazzabuglio di fede e di errore, di misticismo e di sensualità, questo culto esterno così pagano, questa idolatria, vi spaventano? Vi dolete di queste cose, degne dei selvaggi? $\mathrm{E}$ chi ha fatto nulla per la coscienza del popolo napoletano? Quali ammaestramenti, quali parole, quali esempi, si è pensato di dare a questa gente così espansiva, così facile a conquidere, così naturalmente entusiasta? In verità, dalla miseria profonda della sua vita reale, essa non ha avuto altro conforto che nelle illusioni della propria fantasia: e altro rifugio che in Dio.

\section{$\mathbf{V}$}

\section{IL LOTTO}

Ebbene, a questo popolo eccezionalmente meridionale, nel cui sangue s'incrociano e si fondono tante gentili, poetiche, ardenti eredità etrusche, arabe, saracene, normanne, spagnuole, per cui questo ricco sangue napoletano si arroventa nell'odio, brucia nell'amore e si consuma nel sogno: a questa gente in cui l'immaginazione è la potenza dell'anima più alta, più alacre, inesauribile, una grande fantasticheria deve essere concessa.

È gente umile, bonaria, che sarebbe felice per poco e invece non ha nulla per essere felice; che, sopporta con dolcezza, con pazienza, la miseria, la fame quotidiana, l'indifferenza di coloro che dovrebbero amarla, l'abbandono di coloro che dovrebbero sollevarla.

Felice per l'esistenza all'aria aperta, eredità orientale, non ha aria; innamorata del sole, non ha sole; appassionata di colori gai, vive nella tetraggine; per la memoria della bella civiltà anteriore, greca, essa ama i bianchi portici che si disegnano sull'azzurro, e invece le tane dove abita questa gente, non sembrano fatte per gli umani, e dei frutti 
della terra, essa ha i peggiori, quelli che in campagna si dànno ai maiali; e vi sono vivande che non assaggia mai.

Ebbene, il popolo napoletano rifà ogni settimana il suo grande sogno di felicità, vive per sei giorni in una speranza crescente, invadente, che si allarga, si allarga, esce dai confini della vita reale: per sei giorni, il popolo napoletano sogna il suo grande sogno, dove sono tutte le cose di cui è privato, una casa pulita, dell'aria salubre e fresca, un bel raggio di sole caldo per terra, un letto bianco e alto, un comò lucido, i maccheroni e la carne ogni giorno, e il litro di vino, e la culla pel bimbo e la biancheria per la moglie e il cappello nuovo per il marito.

Tutte queste cose che la vita reale non gli può dare, che non gli darà mai, esso le ha, nella sua immaginazione, dalla domenica al sabato seguente; e ne parla e ne è sicuro, e i progetti si sviluppano, diventano quasi quasi una realtà, e per essi marito e moglie litigano o si abbracciano.

Alle quattro del pomeriggio, nel sabato, la delusione è profonda, la desolazione non ha limiti: ma alla domenica mattina, la fantasia si rialza, rinfrancata, il sogno settimanale ricomincia. Il lotto, il lotto è il largo sogno, che consola la fantasia napoletana: è l'idea fissa di quei cervelli infuocati; è la grande visione felice che appaga la gente oppressa; è la vasta allucinazione che si prende le anime.

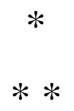

Ed è contagiosa questa malattia dello spirito: un contagio sottile e infallibile, inevitabile, la cui forza di diffusione non si può calcolare. Dal portinaio ciabattino che sta seduto al suo banchetto innanzi al portoncino, il contagio del lotto si comunica alla povera cucitrice che viene a portargli le scarpe vecchie da risuolare; da costei passa al suo innamorato, un garzone di cantina; costui lo porta all'oste che lo dà a tutti gli avventori, i quali lo seminano nelle case, nelle officine, nelle altre osterie, fino nelle chiese.

La serva del quinto piano, a destra, giuoca, sperando di non far più la serva; ma tutte le serve, di tutti i piani, giuocano, tanto la cameriera del primo che ha le trenta lire al mese, quanto la vajassa del sesto, che ne prende otto, con la dolce speranza di uscir dal servizio, così duro; e si comunicano i loro numeri, fanno combriccola sui pianerottoli, se li dicono dalle finestre, se li telegrafano a segni. La venditrice di frutta, che sta sotto il sole e sotto la pioggia, giuoca, e dal suo angolo di strada, in giù, la moglie del sarto, che cuce sulla porta, la moglie dello stagnino affogata dal fetore del 
piombo, la lavandaia che sta tutto il giorno con le mani nella saponata, la venditrice di castagne che si brucia la faccia e le mani al vapore e al calore del fornello, la venditrice di noci che ha le mani nere sino ai polsi per l'acido gallico, tutte queste donne credono nel lotto, giuocano fedelmente, ardentemente, al lotto.

Nella stanza stretta, dove otto o dieci ragazze lavorano da sarte, e il bimbo della sarta dorme nella culla e in un angolo frigge il lardo nel tegame sul focolare, una dà i numeri, una seconda ne ha degli altri, la maesta sa i veri, tutte costoro giuocano.

Le pettinatrici del popolo, le cosidette capere, dal grembiule arrotolato attorno alla cintura, dalla testa scapigliata, dalle mani unte, che pettinano per un soldo al giorno, portano in giro i numeri alle loro clienti, ne ricevono in cambio degli altri, sono il gran portavoce dei numeri. In tutte le officine dove gli operai napoletani sono riuniti a un lavoro lunghissimo, così male retribuito, il lotto mette radici profonde; in tutte le scuole popolari giuocano le maestre e giuocano le alunne grandicelle, in comitiva, riunendo i soldi della colazione. Dove sono riunite, a vivere di peccato, le disgraziate donne di cui Napoli ha così grande copia, il lotto è una delle più grandi speranze: speranza di redenzione.

Ma non credete che il male rimanga nelle classi popolari. No, no, esso ascende, assale le classi medie, s'intromette in tutte le borghesie, in tutti i commerci, arriva sino all'aristocrazia. Dove vi è un vero bisogno tenuto segreto, dove vi è uno spostamento che nulla vale a riequilibrare, dove vi è una rovina finanziaria celata ma imminente, dove vi è un desiderio che ha tutte le condizioni dell'impossibilità, dove la durezza nascosta della vita più si fa sentire, e dove solo il danaro può esser rimedio, ivi il giuoco del lotto prende possesso, domina.

Segretamente, giuocano tutte le ragazze da marito che non hanno un soldo di dote; giuocano tutti i numerosi impiegati al Municipio, alle Banche, all'Intendenza, al Dazio Consumo; tutti i pensionati che non possono vivere con la pensione e che non avendo nulla da fare fanno la cabala, studiano la scienza negromantica del lotto, giuocano disperatamente e hanno sempre il libretto in pegno; tutti i commessi di negozio, che guadagnano quaranta lire al mese, sanno i numeri certi e li giuocano ogni settimana. Grande reddito, al lotto, lo dànno i magistrati: pagati miserevolmente, essi che rappresentano la più grande equità morale, esposti a tentazioni che respingono con 
una inflessibilità degna di maggior premio, provvisti di molti figli, rovinati dai traslocamenti, la loro debolezza, la loro speranza consiste nel lotto.

I piccoli commercianti che si dibattono continuamente con le cambiali e fanno una lotta quotidiana col fallimento, finiscono per aggrapparsi a questa tavola così incerta del lotto; i grandi giuocatori di borsa, che vivono sopra il taglio di un rasoio e son capaci di ballarvi sopra un waltzer, a furia di febbre del giuoco, assaggiano volentieri la speranza del lotto. Tutti questi sintomi del male saliente alle classi dirigenti, mi constano, per aver visto, udito, compreso e intuìto.

Le signore dell'aristocrazia giuocano, un po' per burletta, un po' con la speranza di un nuovo braccialetto, un po' per l'oppressione di una nota di sarta che il marito non salderà mai. Anche quelli che dovrebbero esserne salvi, perchè abituati al male, perchè ci stanno sempre in mezzo, gli impiegati dei banchi-lotto, i postieri, non possono resistere alla tentazione. Onde, alle quattro del sabato, tutti quelli che sono più ammalati, non possono più aspettare, e si recano all'Impresa, in una stretta strada fra la via Pignatelli e la via di Santa Chiara, per assistere alla estrazione dei numeri.

Ma tutte le serve, le venditrici, le operaie e gli operai, le ragazze e gl'impiegati non possono muoversi di dove sono. E allora un monello parte, va al più vicino posto del lotto e prende i numeri: tutti aspettano. Le persone più franche si fanno sulla porta e alle finestre, le vergognose restano dentro, tendendo l'orecchio. Il ragazzo torna correndo, affannato, si pianta alla bocca del vicolo e grida i numeri, con voce stentorea:

\section{"Vintiquatto!"}

"Sissantanove!"

"Quarantanoie!"

"Otto!"

"Sittantacinche!"

Silenzio universale: tutti impallidiscono.

Ma come tutti i sogni troppo pronunziati, il lotto conduce alla inazione ed all'ozio: come tutte le visioni, esso porta alla falsità e alla menzogna; come tutte le allucinazioni, esso conduce alla crudeltà e alla ferocia; come tutti i rimedi fittizi che nascono dalla miseria, esso produce miseria, degradazione, delitto.

Il popolo napoletano, che è sobrio, non si corrompe per l'acquavite, non muore di delirium tremens; esso si corrompe e muore pel lotto. Il lotto è l'acquavite di Napoli. 


\section{ANCORA IL LOTTO}

Il lotto ha una prima forma letteraria, rudimentale, analfabeta, fondata sulla tradizione orale come certe fiabe e certe leggende. Tutti i napoletani che non sanno leggere, vecchi, bimbi, donne, specialmente le donne, conoscono la smorfia, ossia la Chiave dei sogni a memoria e ne fanno speditamente l'applicazione a qualunque sogno o a qualunque cosa della vita reale. Avete sognato un morto?- quarantasette - ma parlava allora quarantotto - e piangeva - sessantacinque - il che vi ha fatto paura - novanta. Un giovinotto ha una coltellata da una donna? - diciassette, la disgrazia - diciotto, il sangue - quarantuno, il coltello - novanta, il popolo. Cade una casseruola dal suo chiodo, ammala un bimbo, fugge un cavallo, compare un grosso sorcio: numeri, subito.

Tutti gli avvenimenti, grandi e piccoli, sono considerati come una misteriosa sorgente di guadagno. Muore una fanciulletta di tifo; la madre giuoca i numeri, escono, ella esclama: m'ha fatte bbene pure murenne! Una moglie parla dell'amore che le portava suo marito, che è morto; poi soggiunge malinconicamente, che se questo amore fosse stato grande, egli le sarebbe comparso in sogno, per darle i numeri; e se n'è scordato, è un ingrato, poichè egli lo sa che essa è poveretta e dovrebbe aiutarla.

Salvatore Daniele squarta la Gazzarra: biglietto; il popolo dice: chella è mmorta, mo, almeno ce refrescasse a nnuie, che simmo vive. Salvatore Misdea ammazza sette soldati: biglietto. La legge ammazza Misdea: biglietto. Su le porte, nei bassi, alle cantonate, i numeri sono discussi da comitati e sottocomitati; il biglietto è stabilito. Non esce: avevano sbagliato, dovevano mettere questo numero e quest'altro, che sono usciti.

Questa scienza della smorfia è così profonda, così abituale, che per dare del pazzo a qualcuno si dice: è nu vintiroie (ventidue, matto), e crescendo man mano la collera, tutte le ingiurie avendo un numero relativo, si dicono in gergo del lotto. Una donna dà un pugno ad un'altra, e le rompe la faccia; davanti al giudice, si scolpa, dicendo: m'ha chiammata sittantotto; il giudice deve prendere la smorfia e vedere a che corrisponde di oltraggioso quel numero.

$$
\begin{gathered}
* \\
* *
\end{gathered}
$$

La cabala esiste più per le classi superiori che per le inferiori: ma essa vi discende. Certo, nel popolo non si comprano giornali cabalistici, settimanali, dagli strani titoli: il Vero amico, il Tesoro, il Fulmine, il Corno d'abbondanza, che costano dieci lire all'anno di abbonamento, compilati da una redazione ignota; nè il popolo corrisponde 
con quei professori di matematica che abitano al vico Nocelle dodici, o a San Liborio, quarantotto, o a vico Zuroli, tre, e che dànno, nelle quarte pagine, la fortuna a chi paga le dieci lire. Ma qualche cosa vi trapela: il tal signore sa inumeri, lo aspettano nella strada, gli mettono in mano un paio di lire e quello si contenta: è un piccolo affare.

L'assistito (dagli spiriti) è un cancro che rode le famiglie borghesi, un convulsionario pallido che mangia molto, che finge di avere o ha delle allucinazioni, che non lavora, che parla per enigmi, che fa credere a delle macerazioni crudeli e che vive alle spalle di coloro che lo venerano. Ma, dalla casa borghese, per mezzo della cameriera, del servo, della lavandaia, la reputazione dell'assistito arriva nel popolo; e l'assistito vi estende la sua azione mistica, vi raccoglie dei guadagni piccoli, ma insperati, vi fa degli adepti e finisce per camminare nelle vie, circondato sempre da quattro o cinque persone, che lo corteggiano e studiano tutte le sue parole.

\section{$*$}

Ma il grande aiutatore del popolo, la provvidenza del popolo, la sua fede, la sua credenza incrollabile, è il monaco. Il monaco sa i numeri: questo è il domma. Se non li dice, è perchè il Signore gli ha proibito di aiutare i peccatori; se li dice, e non escono, è perchè nel giuocatore è mancata la vera fede; se li dice e vengon fuori, la novella si spande in un minuto, il povero monaco diventa afflitto da una popolarità pericolosa. È come l'artista che ha fatto un capolavoro: guai se non continua a farne, egli è perduto. Il monaco che ha solamente fatto prendere un ambo, ha speranza di viver quieto: ma colui che ha dato tre numeri e sono usciti tutti tre, stia in guardia. Cercheranno di sedurlo in tutti i modi, coi doni, coi regali di denaro, con le offerte, con le messe, con le elemosine; lo faranno pregare dai bimbi, dalle donne, dalle nonne vecchie; l'aspetteranno in istrada, alla porta della chiesa, presso il confessionale, alla porta del convento; andranno a raccomandarsi a sua madre, a suo fratello, a sua zia; lo assedieranno mattina e sera; lo bastoneranno; lo sequestreranno, torturandolo; lo lasceranno morire di fame, perchè almeno in agonia dia i numeri. Sono cose accadute. Spesso, per salvarsi, un monaco si fa mandare da un paese all'altro, dal suo superiore; scompare, il popolo dice che se lo ha portato via la Madonna.

$$
\begin{aligned}
& * \\
& * *
\end{aligned}
$$

Il popolo napoletano giuoca per quanto più ha denaro. Per quanto sia povero, trova sempre sei soldi, mezza lira, al sabato, da giuocare; ricorre a tutti gli espedienti, 
inventa, cerca, finisce per trovare. La sua massima miseria non consiste nel dire che non ha pranzato, consiste nel dire: Nun, m'aggio potuto jucà manco nu viglietto; chi ascolta, ne resta spaventato. Fra il venerdì sera e il sabato mattino, è tutto un agitarsi di gente che vuol giuocare e che non ha denaro; gli operai si fanno anticipare una giornata, le serve rubano orrendamente sulla spesa, i mendicanti nelle vie crescono smisuratamente dal venerdì al sabato, quello che si può ancora vendere, si vende, quello che si può impegnare, si impegna. Anzitutto vi sono i biglietti popolari da giuocare, quelli che si giuocano sempre, perchè è una tradizione, perchè è un obbligo, perchè non se ne può fare a meno: l'ambo famoso, sei e ventidue; il terno famoso, cinque, ventotto, e ottantuno; il terno della Madonna, otto, tredici e ottantaquattro. Questi terni, per fortuna del governo, non escono che ogni venti anni: quando è uscito, dopo moltissimi anni di attesa, l'ambo sei e ventidue, il governo ha pagato due milioni di piccole vincite, di cinque e di dieci lire l'una; e tutta Napoli si è coperta di tavolelle, vale a dire che tutti hanno pranzato o cenato con la vincita, per ricominciare a giuocare, la settimana dopo, con maggior ardore.

E ognuno ha il suo biglietto speciale, che gioca ogni settimana, da anni ed anni, con una fede che mai non crolla: un lustrascarpe ne giuocava uno da trent'anni e glielo aveva lasciato in eredità suo padre, morendo, insieme con la cassetta per lustrare; erano usciti degli ambi, tre o quattro volte, in trent'anni; il terno, mai. Un portinaio ne giuocò uno, per quarantacinque anni, senza prender mai nulla: la prima settimana che per un caso singolare, se ne scordò, il terno uscì - il portinaio morì di dolore.

E vi è sempre il biglietto del grande avvenimento, rissa o suicidio, revolverata $\mathrm{o}$ veleno; e infine vi è il biglietto cabalistico, quello strappato all'assistito o al monaco.

Questi quattro biglietti bisogna giuocarli a ogni modo; rappresentano una media variabile da cinquanta centesimi a due lire la settimana. Quando il napoletano non ha più che due soldi, li va a giuocare al gioco piccolo, o lotto clandestino.

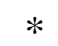

$* *$

Per lo più le mezzane di questa grande frode, sono le donne. Una di queste, sudicia, lacera, porta in una lunga tasca, sotto la gonnella, un registro: viene il giuocatore o la giocatrice, deposita due soldi e dice i numeri: in cambio ha un pezzetto di carta sporca, dove sono scritti col lapis i numeri e la promessa, invariabile: uno scudo l'ambo... quaranta scudi il terno. La donna compie il suo giro nel quartiere, tutti la 
conoscono, tutti sanno che mestiere fa, tutti l'aspettano: denunziarla? Nessuno l'oserebbe, è una benefattrice.

Questi introiti sono larghi naturalmente; a furia di due soldi si arriva a centinaia e centinaia di lire: i tenitori di gioco piccolo arricchiscono quasi tutti.

Alla Riviera s'incontrano degli equipaggi di ricchi borghesi, arrivati a questa ricchezza col lotto clandestino; si conoscono perfettamente le persone, ma esse non compaiono, hanno i loro agenti. Il popolano ha una cieca fede in questi tenitori di gioco piccolo: ma bene spesso, nel pomeriggio del sabato, se il tenitore ha da pagare molte vincite, si affretta a sparire, con tutti i suoi registri, e non paga nessuno. Che importa?

La settimana appresso un'altra donna ricomincia il suo giro e la gente ci capita di nuovo, come attratta, invincibilmente. Che delizia per chi giuoca e per chi prende i quattrini, frodare il governo!

Ogni tanto la questura arresta quattro o cinque di questi agenti, di queste mezzane, essi sono condannati al carcere, alla multa; che importa? Scontano la pena, pagano la multa, escono, ricominciano da capo, con più ardore. Vi è chi è stato condannato cinque volte per gioco piccolo: e ha un palazzo, e si lagna della persecuzione del governo, e la sua condanna la chiama na disgrazia. L'aver messo il biglietto a due soldi, non è valso a nulla, pel governo: la frode ha continuato, più fiorente, appoggiata su questa grande allucinazione.

$* *$

Ora la statistica porta: che nei giorni di giovedì, venerdì e sabato, avvengono maggiori furti domestici; che in questi tre giorni si fanno più pegni al Monte di Pietà, che in questi tre giorni le agenzie private di pegni, sono affollatissime; che in questi tre giorni, ma specialmente nel pomeriggio del sabato, avvengono maggiori risse; che infine le cose più brutte, più laide, più ignobili e più violente avvengono in questo fatale periodo, e che in questi giorni il popolo napoletano si mette nelle mani dell'usura: il vero cancro, di cui muore.

\section{VII}

\section{L'USURA}

Una povera donna che ha bisogno di cinque lire per pagare il padrone di casa, va a cercarle in prestito da donna Carmela, che dà il denaro cu a credenza. Prima di andarci, esita molto, ha paura e vergogna, ma visto che non può fare diversamente si decide. Donna Carmela è una donna grassa e grossa che esercita per lo più una 
professione di lusso, rammenda merletti, trapuntisce le grandi coltri di bambagia che si usano in Napoli, d'inverno ricama in oro sul velluto: infine una professione per la forma, che lascia godere di lunghi ozii; ma la sua vera professione è il prestar quattrini alla povera gente. Donna Carmela è verbosa e affettuosa in questo primo colloquio con la povera donna: la rincora, la compatisce, se occorre, le confessa di essere stata egualmente alle strette, e la manda via, tutta racconsolata, con le cinque lire, - vale a dire con quattro lire e mezzo. Il prestito è fatto per otto giorni, l'interesse è di due soldi per lira. Si paga anticipato: quindi, sulle cinque lire, la povera donna lascia cinquanta centesimi. Gli otto giorni passano, le cinque lire da restituire la povera donna non le ha, allora, tutta rossa di vergogna, prega donna Carmela di contentarsi di un'altra settimana d'interesse, cinquanta centesimi: donna Carmela non dice nulla e intasca i dieci soldi. Così passano quattro, cinque, fino a dieci settimane, senza che la povera donna abbia mai potuto riunire le cinque lire: e ogni lunedì le tocca pagare l'interesse del dieci per cento per settimana, e dopo la quinta settimana donna Carmela è diventata una iena, bisogna pregarla perchè non gridi, perchè non faccia delle scene, essa vuole il suo denaro, vuole il sangue suo, l'interesse non le serve, le servono i quattrini del capitale. Sulla soglia delle porte, alle porte delle officine, ogni sabato, ogni lunedì, si ode la voce irosa di donna Carmela: essa, dal mattino, è in giro per esigere, ricoglie, e fa tremare uomini e donne, con il suo tòno alto e imperioso. In un posto ha da esigere una lira, in un altro due, in un altro cinque: e non osano ribellarsi a lei, non avendo da pagarla, non osano ribellarsi, potendo aver sempre bisogno di lei. Quella donna grassa è implacabile: sa la sua potenza: se una serva non paga, essa minaccia di fare uno scandalo con la padrona, se una donna non paga, essa minaccia di dirlo al marito, se un operaio non paga, essa sa l'indirizzo del capo officina, e cui va a denunciarlo. Ella è astuta e cauta, audace e sboccata: ella resta sempre nella posizione di una benefattrice, a cui codesti ingrati rodono le fibre e bevono il sangue. E infatti nessuno le dà una coltellata, nessuno la bastona, nessuno la insulta, e quel che è più forte ancora, nessuno ha il coraggio di negarle i quattrini: l'onestà del popolo napoletano non è neppur capace di truffare una usuraia. Non le danno neppure torto nelle sue escandescenze: e cercano sempre di mansuefarla.

Quando una povera donna napoletana ha bisogno di un grembiule, di un vestito, di un fazzoletto da collo, di un paio di camicie, non avendo quattrini per comperarle, si decide ad andare da donna Raffaela che dà la robba cu a credenza. Quest'altra usuraia prende, a basso prezzo, tela e percallo e fazzoletti di cotone dai negozi: e li rivende alla 
povera gente. Ogni oggetto, naturalmente, è pagato molto più caro del suo valore: primo guadagno. Poi, come all'altra usuraia, bisogna pagare l'interesse del dieci per cento alla settimana, sulla somma. Questi debiti, complicati continuamente, pesano sulla esistenza delle povere donne, per mesi e mesi: talchè, molto spesso, il grembiule si è consumato, la veste è lacera, le camicie sono bucate, e la povera donna ne ha pagato tre volte il valore, e il debito rimane uguale: donna Raffaela è furibonda, ella grida come una energumena, vuole strappare dal collo della donna il fazzoletto che le ha venduto, vuole sciogliere dai fianchi il grembiule e va gridando: Chesta è robba mia! T'aie arrobbato lu sango mio! Come l'altra, ella finisce per incassare quattro o cinque volte il capitale; come l'altra, ella è necessaria alla povera gente, la quale non reagisce mai contro queste violenze; come l'altra, ella non arrischia mai che piccoli capitali, preferendo di far piccoli e molti affari, dove non vi sono rischi, a grossi affari che offrono sempre dei pericoli.

Le agenzie private di pegni rappresentano l'usura organizzata in modo legale. Queste agenzie non sono succursali del Monte di Pietà, che debbano conformarsi alle tariffe del grande istituto di misericordia; ma sono speculazioni debitamente autorizzate e viventi con capitali proprii. Per lo più sono esercitate da donne, profondamente sottili nella loro volgarità, nella loro ignoranza, e vengono messe su con pochi capitali. Anzitutto, in queste agenzie, l'oggetto è deprezzato vilmente, specie se non è oro: e il primo guadagno è su questo. Vi si paga un fantastico diritto di registro, poi un tanto per la cartella, poi l'interesse anticipato per un mese, tutto questo così complicato, così bene salvaguardato, così apparentemente legale, che queste agenzie esigono il cinque per cento d'interesse al mese, senza che nessuno abbia il diritto di lagnarsi. So di una moglie di impiegato che dovette impegnare il suo unico vestito di seta, il vestito delle nozze, che era costato duecentocinquanta lire, in una di queste agenzie, tenuta da una grossa donna Gabriela: n'ebbe trentasei lire, di cui ritirò soltanto trent'una, lasciandone cinque per interesse, per la cartella ed il diritto di registro. Per sei mesi, tremando che non le vendessero il suo vestito e non avendo le trentasei lire, le toccò pagare, ogni mese, cinque lire, vale a dire che restituì i quattrini presi: al settimo non ebbe neppure quelle cinque lire ed il vestito fu venduto. Accorse, per vedere di prendere il di più, poichè il vestito era nuovo, e si era dovuto vendere bene: invece era stato liberato per trenta lire; almeno così apparve dal libro. Ebbe poi il piacere d'incontrare donna Gabriela al teatro col suo vestito indosso e carico di oro e di gioielli, ricomprati dall'agenzia. Poichè molte di queste amano di sovraccaricarsi degli oggetti che hanno in deposito, e più di una 
popolana vede passare l'impegnatrice che va alla passeggiata, portando al collo il laccetto d'oro che ella ha dovuto impegnare, alle orecchie gli orecchini di una vicina, e sulle spalle il mantello di velluto della signora del terzo piano: e dietro le porte, dietro le finestre, quando l'impegnatrice passa, vi sono dei sospiri repressi, delle lagrime inghiottite, dei pallori subitanei: l'impegnatrice sembra un idolo indiano a cui si sacrifichi oro e sangue. Alcune impegnatrici, più astute e più calcolatrici, impegnano di nuovo, ma al Banco, gli oggetti di oro e di valore, guadagnandoci ancora, poichè il Banco dà onestamente il terzo del valore ed esse neppure il quinto: così aumentano i loro capitali, e mettono gli oggetti al sicuro.

Ma perchè - si domanda - la povera gente non si rivolge ai due Banchi dello Spirito Santo e di Donnaregina? Perchè si fa spogliare da queste agenzie? Gli è che a questi Banchi governativi, il tramite è molto lungo - e molta gente non ha pazienza, non sa come fare, vuole sbrigarsi presto, è presa da una necessità urgentissima e preferisce entrare in una delle prime agenzie che trova dove la servono subito, senza formalità e senza parole; gli è che in questi Banchi governativi, la pubblicità è sempre grande, e una persona timida vi arrossisce di vergogna e preferisce entrare nella penombra discreta delle agenzie private, dove tutto sembra fatto con grande segretezza; gli è che il venerdì e il sabato, poichè il popolo napoletano deve giuocare al lotto, e ha giuocato, la folla è così grande che i Banchi governativi non bastano più e il popolo si riversa nelle agenzie private.

Ora, calcolate. Ogni vicolo ha la sua donna Carmela, ogni strada la sua donna Raffaela, ogni angolo di piazza ha la sua agenzia autorizzata; e in certe strade nere, ogni tre botteghe, s'impegna. Calcolate, moltiplicate, pensate alla miseria, pensate al lotto: da un lato l'avidità e la furberia: dall'altro l'onestà e l'ingenuità, il bisogno, la miseria. Di questo cancro, l'usura, agonizza in una infelicità infinita la gente napoletana.

\section{VIII}

\section{IL PITTORESCO}

Alla mattina, se avete il sonno leggiero, fra i tanti rumori napoletani, udirete uno scampanio in cadenza, che ora tace, ora ricomincia dopo breve intervallo: e insieme un aprir e chiuder di porte, uno schiuder di finestre e di balconi, un parlare, un discutere a voce alta, dalla strada o dalle finestre. Sono le vacche che vanno in giro per un paio d'ore, condotte, ognuna, da un vaccaro sudicio, per mezzo di una fune: le serve comprano i due soldi di latte, attardandosi sulla soglia del portone, litigando sulla 
misura; molte, per non avere il fastidio di far le scale, calano dalla finestra un panierino dove è un bicchiere vuoto e un soldo, e da sopra protestano che è troppo poco, che il vaccaro è un ladro e fanno risalire il panierino con molta precauzione, per non versare il latte; poi sbattono rabbiosamente le finestre.

Queste vacche si fermano innanzi a ogni porta, nel loro giro mattinale: dove le serve dormono ancora, il vaccaro grida forte, acalate o panaro; se non sentono, batte forte il campanaccio della vacca. È un quadro pittoresco, mattinale; quelle vacche tutte incrostate di fango, quel vaccaro dalle mani nere che sporcano il bicchiere, quelle serve scapigliate e discinte, quelle comari dalla camiciuola macchiata di pomidoro.

L'altro lato del quadro, è nel pomeriggio; dalle quattro alle sei, uno scampanellìo acuto e fitto: sono le mandre di capre che scorazzano per tutte le vie della città, ogni branco guidato da un capraro, con un bastone.

A ogni portone il branco si ferma, si butta a terra, per riposarsi, il capraro acchiappa una capra, e la trascina dentro il portone, per mungerla innanzi agli occhi della serva, che è scesa giù; talvolta la padrona è diffidente, non crede nè all'onestà del capraro, nè a quella della serva; allora capraro e capra salgono sino al terzo piano, e sul pianerottolo si forma un consiglio di famiglia, per sorvegliare la mungitura del latte.

Il capraro e la sua capra ridiscendono, galoppando, dando di petto, contro qualche infelice che sale e che non aspetta questo incontro: giù, alla porta, è un combattimento fra il capraro e le sue capre per farle muovere, fino a che queste prendono una corsa sfrenata, massime quando si avvicina la sera e sanno che ritornano sulle colline.

In tutte le città civili, queste mandre di bestie utili ma sporche e puzzolenti, queste vacche non si vedono per le vie: il latte si compra nelle botteghe pulite e bianche di marmi.

A Napoli, no: è troppo pittoresco il costume, per abolirlo. Nessun municipio osa farlo. La gran riforma, in venticinque anni, è stata che non potessero girare per la città i maiali, come era prima permesso.

$$
\text { * }
$$

Un'altra cosa molto pittoresca, è il sequestro delle strade, fatto per opera dei piccoli bottegai o dei rivenditori ambulanti. Che quadri di colore acceso, vivo, cangiante, che bella e grande festa degli occhi, che descrizione potente e carnosa, potrebbero ispirare a uno dei moderni sperimentali, troppo preoccupati dell'ambiente! 
Per via Roma, la più importante strada della città, il tratto da San Nicola alla Carità, fino alle Chianche della Carità, vale a dire, due piazze, due lunghi marciapiedi, sino alle otto della mattina, è abbandonato ai rivenditori di frutta, di erbaggi, di legumi: un contrasto di fichi e di fave, di uva e di cicoria, di pomidori e di peperoni; e un buttar acqua, sempre, uno spruzzare, uno scartare la roba fradicia; dopo le otto, quel tratto è un campo di battaglia di acque fetenti, di buccie, di foglie di cavolo, di frutta marcite, di pomidori crepati, tanto che, come la mano fatale di lady Macbeth, che tutte le acque dell'Oceano non potevano lavare, quel tratto di strada, via Roma, malgrado le premure degli spazzini, non arriva mai a detergersi.

Intanto il grande mercato di Monteoliveto lì presso, resta semi-vuoto, con la malinconia dei grandi fabbricati inutili; quello di San Pasquale a Chiaia, è addirittura chiuso; il venditore napoletano non vuole andarci, vuol vendere nelle strade.

Tutto il quartiere della Pignasecca, dal largo della Carità, sino ai Ventaglieri, passando per Montesanto, è ostruito da un mercato continuo. Vi sono le botteghe, ma tutto si vende nella via; i marciapiedi sono scomparsi, chi li ha mai visti? I maccheroni, gli erbaggi, i generi coloniali, le frutta, i salami ed i formaggi, tutto, tutto nella strada, al sole, alle nuvole, alla pioggia; le casse, il banco, le bilancie, le vetrine, tutto, tutto nella via; vi si frigge, essendovi una famosa friggitrice; vi si vendono i melloni, essendovi un mellonaro famoso per dar la voce; vanno e vengono gli asini carichi di frutta; l'asino è il padrone tranquillo e potente della Pignasecca.

Qui il romanzo sperimentale potrebbe anche applicare la sua tradizionale sinfonia degli odori, poichè si subiscono musiche inconcepibili: l'olio fritto, il salame rancido, il formaggio forte, il pepe pestato nel mortaio, l'aceto acuto, il baccalà in molle. Nel mezzo della sinfonia della Pignasecca, vi è il gran motivo profondo e che turba; la vendita del pesce, specialmente del tonno, in pieno sole, su certi banchi inclinati, di marmo. Alla mattina il tonno va a ventisei soldi e il pescivendolo grida il prezzo con orgoglio: ma, come la sera arriva, per il declinare dell'ora e della merce, il tonno scende a ventiquattro, a una lira, a diciotto soldi; quando arriva a dodici soldi, la gran nota sinfonica del puzzo ha raggiunto il suo apogeo.

La Pignasecca non può mai essere pulita; nessun Municipio ha mai osato dichiararla via di sbarazzo. Il quartiere del Sangue di Cristo, detto piuttosto 'o sanghe d'e galline, per rispetto al nome del Redentore, se ne ride del Municipio.

Del resto, tutto questo è bellissimo, pel pittore e pel novelliere. 
Nulla di più pittoresco che la strada di santa Lucia, di esclusiva proprietà dei signori pescatori e marinai, intrecciatori di nasse e venditori di ostriche; nonchè delle loro signore mogli, venditrici di acqua sulfurea e di ciambellette, cucinatrici di polipi e friggitrici di peperoni; nonchè dei loro signori figliuoli, in numero indefinito, nudi e bruni come il bronzo.

In quella strada, all'aria aperta, tutto si fa: il bucato e la conserva di pomidoro, la pettinatura delle donne e la spulciatura dei gatti, la cucina e l'amoreggiamento, la partita a carte e la partita alla morra. La strada di santa Lucia appartiene ai luciani, che fanno il loro comodo. Le quattro viottole cieche che salgono da santa Lucia verso la collina, valgono i fondaci del quartiere Mercato, per il luridume: i cavalcavia uniscono le case pencolanti e sbuzzanti, le cordicelle vanno da un balcone all'altro, un lumicino innanzi a una Madonnina nera illumina soltanto la viottola, dove va a cadere tutto il sudiciume di quella gente.

Non vi è più marciapiede, verso il mare: i luciani se lo pigliano tutto, per le nasse, e per le fiasche dell'acqua sulfurea. Nell'estate, anzi, dormono sul marciapiede o sul parapetto e brontolano contro colui che osa passare e svegliarli. Verso le case, non vi si accosta nessuno: lì per scherzo, volano i torsi di spighe e le buccie di fichi e le cantine mettono le tavolelle dei bevitori, nella via.

I luciani sopportano che il tram passi per la loro via, ma vi bestemmiano contro, spesso e volentieri, poichè è una usurpazione della loro strada: le venditrici di acqua sulfurea paiono tanti uomini vestiti da donne, con gli zoccoli dal tacco alto, la gonna corta legata sullo stomaco, le rosette di perle sostenute con un filo all'orecchio, perchè non si spezzi il lobo, pel peso. Sono naturalmente rissose e brutali: vi dànno a bere l'acqua per forza, litigano fra loro, rubandosi gli avventori. Sono indomabili: per poterle governare, il delegato del quartiere deve essere anche un luciano, che le pigli a male parole.

Una volta, due di esse, bastonarono fino all'estenuazione, una guardia municipale che voleva loro assegnare una contravvenzione: è vero, però, che il giorno seguente si quotarono per aiutarne la vecchia madre, mentre il figlio era all'ospedale.

Ma santa Lucia, tutta pittoresca, resta sempre fuori delle leggi dell'edilizia e d'igiene: è un borgo fortificato. 
Forse il colera non vi avrà fatto strage; vi è il mare e vi è il sole. Ma che mare nero, untuoso! Ma qual putrefazione, non illumina quel sole!

È pittoresco, per un amante del colore, veder girare, di sera, per via Roma, un carretto disposto a mensa, su cui, in tanti piattelli, vedi dei castelletti di fichi d'India, sbucciati: un uomo spinge il carretto, una lampada a petrolio vi fumiga, il carretto si ferma ogni tanto. Riparte, lasciando dietro di sè le bucce spinose e sdrucciolevoli.

È pittoresco, assai, per un novelliere, girare dopo mezzanotte: e trovare degli uomini che dormono sotto il porticato di san Francesco di Paola, col capo appoggiato alle basi delle colonne: degli uomini che dormono sui banchi dei giardinetti, in piazza Municipio; dei bimbi e delle bimbe, che dormono sugli scalini delle chiese di san Ferdinando, santa Brigida, la Madonna delle Grazie, specialmente quest'ultima, che ha una larga scala e certi poggiuoli ampli, nel centro di via Roma.

Può piacere all'uno e all'altro, che giusto a due passi da via Roma, vi sia il Chiostro di San Tommaso d'Aquino, dove non vi sono più monaci, ma che è un piccolo fondaco, una piccola Corte dei Miracoli, con le sue vanelle, e le sue botteghe brulicanti di ombre e le case brulicanti di poveri e d'infelici.

Ma in realtà è molto, molto crudele che tutto questo esista ancora, e che creature umane lo subiscano, e che uomini di cuore sopportino che questo sia.

IX

\section{LA PIETÀ}

Quando una popolana napoletana non ha figli, essa non si addolora segretamente della sua sterilità, non fa una cura mirabile per guarirne, come le sposine aristocratiche, non alleva un cagnolino o una gattina o un pappagallo, come le sposette della borghesia. Una mattina di domenica ella, si avvia, con suo marito, all'Annunziata, dove sono riunite le trovatelle, e fra le bimbe e i bimbi, allora svezzati o grandicelli, ella ne sceglie uno con cui ha più simpatizzato, e, fatta la dichiarazione al governatore della pia opera, porta con sè, trionfante, la piccola figlia della Madonna.

Questa creaturina, non sua, ella l'ama come se l'avesse messa al mondo; ella soffre di vederla soffrire, per malattia o per miseria, come se fossero viscere sue; nella piccola umanità infantile napoletana, i più battuti sono certamente i figli legittimi; di battere una figlia di Maria, ognuno ha un certo ritegno; una certa pietà gentilissima fa 
esclamare alla madre adottiva: puverella, non aggio core de la vattere, è figlia della Madonna. Se questa creatura fiorisce in salute e in bellezza, la madre ne va gloriosa come di opera sua, cerca di mandarla a scuola o almeno da una sarta per imparare a cucire, poichè certamente, per la sua bellezza, la bimba è figlia di un principe; in nessun caso di miseria o infermità, la madre adottiva riporta, come potrebbe, la figliuola all'Annunziata. E l'affezione, scambievole, è profonda, come se realmente fosse filiale; e a una certa età il ricordo dell'Annunziata scompare, e questa madre fittizia acquista realmente una figliuola.

Ma vi è di più: una madre ha cinque figli. Il più piccolo ammala gravemente, ella si vota alla Madonna, perchè suo figlio guarisca; ella adotterà una creatura trovatella. Il figlio muore; ma la pia madre, portando il fazzoletto nero che è tutto il suo lutto, compie il voto, lagrimando. Così, a poco a poco, la creatura viva e bella consola la madre della creatura morta, e vi resta in lei solo una dolcezza di ricordo e vi fiorisce una gratitudine grande per la figlia della Madonna.

Talvolta, il figlio guarisce: il primo giorno in cui può uscìre, la madre se lo toglie in collo e lo porta alla chiesa dell'Annunziata, gli fa baciare l'altare, poi vanno dentro a scegliere la sorellina o il fratellino. E fra i cinque o sei figli legittimi, la povera trovatella non sente mai di essere un'intrusa, non è mai minacciata di essere cacciata, mangia come gli altri mangiano, lavora come gli altri lavorano, i fratelli la sorvegliano perchè non s'innamori di qualche scapestrato, ella si marita e piange dirottamente, quando parte dalla casa e vi ritorna sempre, come a rifugio e a conforto.

Un caso frequente di pietà è questo: una madre troppo debole o infiacchita dal lavoro ha un bimbo, ma non ha latte. Vi è sempre un'amica o una vicina o qualunque estranea pietosa, che offre il suo latte; ne allatterà due, che importa? Il Signore penserà a mandarle il latte sufficiente. Tre volte al giorno la madre dal seno arido, porta il suo bambino in casa della madre felice: e seduta sulla soglia, guarda malinconicamente il suo figlio succhiare la vita. Bisogna aver visto questa scena e aver inteso il tono di voce sommessa, umile, riconoscente, con cui ella dice, riprendendosi in collo il bambino: $o$ Signore t'o renne, la carità che fai a sto figlio. E la madre di latte finisce per mettere 
amore a questo secondo bimbo e, allo svezzamento, soffre di non vederlo più: e ogni tanto va a ritrovarlo, a portargli un soldo di frutta, o un amuleto della Vergine: il bimbo ha due madri.

Io ho visto anche altro: una povera donna andava in servizio, non poteva tenere presso di sè il suo bimbo; lo lasciava a un'altra povera donna, che orlava gli stivaletti, e lavorava in casa, cioè nella strada. Ella metteva i due bimbi, il suo e quello della sua amica, nello stesso sportone (culla di vimini), attaccava una funicella all'orlo dello sportone e dall'altra parte al proprio piede, e mentre orlava gli stivaletti, canticchiava la ninna nanna per i due bimbi; mentre orlava gli stivaletti, mandava avanti e indietro il piede, per cullare i due bimbi nello stesso sportone. A un'altra donna che stava in servizio, un'amica teneva il bimbo; ma veniva a portarglielo da molto lontano, per farlo succhiare, sudando, sotto il sole, con quel bimbo pesante in collo. L'intervista accadeva sul pianerottolo o in cucina: e accadevano questi piccoli dialoghi:

- S'è stato cuieto, almeno?

- Cuieto sì, ma tene sempe famme.

- Core de mamma soia!

Poi l'allattamento finiva, l'amica riprendeva il bimbo non suo, dicendogli:

- Iammocene, a' casa, ja'; core de la zia, saluta a mammà.

E se ne andava, tranquillamente, senza mormorare, mentre la madre, dal finestrino della cucina, guardava ancora una volta suo figlio.

$* *$

È naturale che il popolo non possa far carità di denaro, al più povero di lui, non avendone; ma si vedono e si sentono carità più squisite, più gentili.

Una cuoca si metteva sempre di malumore quando la padrona ordinava il brodo: era soltanto felice quando si ordinavano maccheroni o legumi, o risotto, grosse nutrienti minestre. $\mathrm{Fu}$ lungamente sospettata di ingordigia, sebbene alla sua personcina malandata, fosse più necessario il brodo che i maccheroni: in realtà ella dava la sua minestra, ogni giorno, ai due bimbi della portinaia, e preferiva dar loro un grosso piatto, anzichè tre cucchiaiate di brodo: ella rimaneva senza.

Alla sera, quando vanno via, tutte le serve portano un fagottino degli avanzi del pranzo, quando la padrona ha la bontà di darli loro: e non servono per sè, sono per un fratellino, o per un nipote o per una madre vecchia o per qualche povera donna che non ha altro. 
Nessuna serva mangia mai tutto quello che le date: tre quarti, una metà, talvolta tutto, è destinato a un'altra persona.

E gli ammalati degli ospedali, la gente carcerata, trovano sempre una sorella, una zia, una comare, un amica, un'amante che si torturano una settimana, per poter comperare al giovedì o alla domenica, quattro aranci da sollevare la sete dell'infermo o della inferma, che lavano di notte, in fretta e in furia, la camicia del carcerato, per potergliela portare il giorno seguente, lavata e stirata.

Bisogna andare a vedere che cosa sono le porte degli ospedali, nei giorni di visita: e che folla femminile vi si accalca, pallida e ansiosa! Io ho visto una moglie, a cui il marito era morto all'ospedale, in un giorno, andare dal direttore, da quanti medici potette avere l'indirizzo, dalla direttrice delle suore, dalle suore, dagli inservienti, e piangere, e pregare, e scapigliarsi e scongiurarli, in nome di Cristo, che non le squartassero il marito. L'idea della morte la sopportava, ma l'autopsia la esasperava.

$$
\text { * }
$$

Nessuna donna che mangi, nella strada, vede fermarsi un bambino a guardare, senza dargli subito di quello che mangia: e quando non ha altro, gli dà del pane. Appena una donna incinta si ferma in una via, tutti quelli che mangiano o che vendono qualche cosa da mangiare, senza che ella mostri nessun desiderio, gliene fanno parte, la obbligano a prenderlo, non vogliono avere lo scrupolo.

E i poveri che girano, sono aiutati alla meglio, da quella gente povera: chi dà un pezzo di pane, chi due o tre pomidoro, chi una cipolla, chi un po' d'olio, chi due fichi, chi una paletta di carboncini accesi: una donna, per fare la carità in qualche modo, lasciava che una mendicante venisse a cuocere sul proprio fuoco, sul focolaretto di tufo, il poco di commestibile che la mendicante aveva raccattato. Tanto avrebbe dovuto perdersi, quel resto del fuoco, dopo la sua cucina; era meglio adoperarlo a sollevare una miserabile.

Un'altra faceva una carità più ingegnosa: essendo già lei povera, mangiava dei maccheroni cotti nell'acqua e conditi solo con un po' di formaggio piccante, ma la sua vicina, poverissima, non aveva che dei tozzi di pane secco, duro.

Allora quella meno povera regalava alla sua vicina l'acqua dove erano stati cotti i maccheroni, un'acqua biancastra che ella rovesciava su quei tozzi di pane, che si facevano molli e almeno avevano un certo sapore di maccheroni. 
Una giovane cucitrice era stata a Gesù e Maria, l'ospedale, con una polmonite; poi si era guarita, e pallida, esaurita, sfinita, era venuta via. Pure l'ospedale, per assisterla ancora in vista di una tisi probabile, le concedeva, ogni mattina, quattro dita di olio di fegato di merluzzo, che ella doveva andare a prendere, lassù. Ella capitava ogni mattina, col suo bicchiere, sino a che fu rimessa completamente in salute: e allora le dissero che non le avrebbero più data la medicina. Ella si confuse, impallidì, pianse, pregò la monaca che per carità, non gli sospendessero quell'olio - e infine fu saputo che di quell'olio, ella si privava per darlo in elemosina a una povera donna - la quale per miseria, superato il naturale disgusto, lo adoperava a condire il pane o a friggerci un soldo di peperoni.

E ancora un altro fatto mi rammento. Un giorno, al larghetto Consiglio, una donna incinta, presa dalle doglie, si abbattè sugli scalini e partorì nella strada. Il tumulto fu grande: ella taceva, ma per pietà, per commozione, molte altre donne strillavano e piangevano. E in poco tempo, da tutti i bassi, da tutte le botteghe, da tutti i sottoscala, vennero fuori camiciole e fasce per avvolgervi la povera creaturina, e lenzuola per la povera puerpera. Una madre offrì la culla del suo bimbo morto; un'altra battezzò il bimbo, facendogli il segno della croce sul visino; una terza questuò per tutte le case del vicinato; una quarta, serva, si offrì e andò a fare il servizio per la povera puerpera. La moglie del fornaio divise il suo letto, con la puerpera: e il fornaio dormì sopra una tavola per dieci giorni, avendo per cuscino un sacco. E quella miserella piangeva di emozione, ogni volta che baciava suo figlio.

Roma, autunno 1884

\section{IL VENTRE DI NAPOLI (ADESSO)}

\section{IL PARAVENTO}

L'impressione che si aveva, entrando in Napoli, dalla stazione ferroviaria, venti anni or sono, era di giungere in una città angusta, male odorante, sporca, affogata di case di tutte le altezze, di tutti i colori, portanti, tutte, il marchio del decadimento e del sudiciume. Se, poi, trascorso il vecchio Corso Garibaldi, la carrozzella del forastiero rallentava un poco il passo, in via Marina, in quella strada eternamente disselciata, dalle 
buche profonde, ove si trabalzava così maledettamente, se il forastiero lasciava il suo portamantelli sul soffietto, o collocava il nècèssaire da viaggio sulla via Marina, in quella strada eternamente disselciata, dalle buche profonde, ove si trabalzava così maledettamente vi era la rapina, quando non ne accadevano due o tre con l'agile ladruncolo che fuggiva nelle viuzze e nelle viottole, alle spalle della Marina. E alla impressione estetica assai deludente pel forastiero che ancora non era giunto nel rione della Beltà, cioè verso la Riviera si univa un ribrezzo morale, di cui non solo le oneste e sincere guide Baedeker erano l'eco, ma di cui tutti i viaggiatori formavano una larga e invincibile propaganda.

Niuno dubbio che, dopo venti anni, la impressione estetica sia mutata completamente. La piazza della Stazione, ormai, ha una vastità degna di una metropoli e le tre ampie strade che vengono di fronte al forestiero, le due enormi arterie a dritta e a sinistra, i grandi palazzi che formano gli angoli della via, tutte queste cose grandi, piene di luce, piene di aria, tutte queste cose che hanno l'aspetto nitido o quasi, danno agli occhi curiosi una prima visione gradevole. Entrando, poi, nel Rettifilo, l'occhio un po' distratto, un po' stanco del viaggiatore, scorrendo rapidamente, finisce per avere un senso di ammirazione, per la larghezza di questa via, per il suo disegno che, sino ad un certo punto è bello. Mancano, è vero gli alberi, che formano la poesia di tutti i paesi civili del mondo, anche escludendo Parigi ove gli alberi sono la delizia e l'ammirazione dei cittadini: mancano gli alberi e vi sono, in cambio, a irrisione nostra, alcune pianticelle tisiche, mal piantate, non coltivate, non protette e, viceversa, esecrate, odiate, perseguitate dalle autorità istesse, dai cittadini e dai monelli: tanto che sarebbe meglio sradicarle, anzi che assistere a quella lenta agonia di cui nessuno ha pietà, non il sindaco, non l'assessore dei giardini, non i proprietarii delle case, non quelli dei magazzini, salvo la vana pietà di qualche malinconico viandante, che rammenta gli alberi, non di Parigi, per l'amor di Dio, ma quelli di Milano e di Torino, città a cui il Signore non dette il paesaggio ma a cui, gli uomini, si affrettarono a dare il verde e l'ombra dei begli alberi, riposo degli occhi, sogno vago dell'anima. Basta! Il Rettifilo ha una linea maestosa, il suo insieme colpisce specialmente se, traversandolo rapidamente, guardandolo senza troppo analizzarlo, non ci si accorge delle svariate bruttezze degli svariati palazzi nuovissimi che vi sono sorti, dei loro colori diversi, alcuni chiassosi, delle goffe e pretenziose ornamentazioni di alcuni fra essi: questo, però, è, purtroppo un male comune a tante altre belle città italiane, dove accanto agli splendori, antichi e alle profonde eleganze del gusto, gli architetti moderni hanno elevato i monumenti della loro 
completa ignoranza e della loro perfetta assenza di senso estetico. Quando si sono visti abbattere i meravigliosi sentieri ombrosi di quella villa incantevole che era la Ludovisia, a Roma, quando quel bosco sacro alla beltà e alla grazia, è sparito, per dar luogo ai quartieri Ludovisii, possiamo sopportare in pace anche le laidezze di non tutti i palazzi del Rettifilo; anche perchè, alcuni fra essi sono, se non altro, semplici, poichè, fortunatamente l'architetto non aveva fantasia; e qualcuno, forse, ha persino delle linee eleganti. Non bisogna guardar troppo, ecco tutto, bisogna sogguardare, e così la vivezza della grande fontana, in piazza della Borsa, nasconderà il dislivello famoso e incorreggibile di via Guglielmo Sanfelice, mentre il solenne edificio della Borsa gli farà credere, al viaggiatore, chi sa quale mirabolante giro di affari e la gabbia aerea dei telefoni, a una rete di abbonati che serri tutta la città. Per fortuna, le guide tacciono su queste circostanze; il viaggiatore non vede che l'esterno; e la messa in iscena del Rettifilo, del resto abbastanza felice, ottiene il suo effetto. Che se, poi, qualche conoscente napoletano, qualche compagno di viaggio più esperto, narra al viaggiatore che il Rettifilo ha tagliato in due il ventre di Napoli, attraversando i quattro quartieri popolari e popolosi di Mercato Vicaria, Pendino e Porto; che questo Rettifilo non è stato fatto solo per arrivare più presto e meglio alla stazione ferroviaria; non è stato fatto solo per $i$ grandi industriali che vendon tessuti di lana e di cotone; non è stato fatto solo per avere una larghissima via; ma è stato fatto in nome di un criterio assoluto d'igiene e quindi di civiltà, allora la sua impressione si viene sempre più migliorando. Il Rettifilo era, doveva essere, dovrebbe essere l'apportatore dell'aria, della salute, della pulizia di migliaia e migliaia di popolani napoletani: il suo ufficio, realizzando una idealità di carità civile che vollero Umberto Primo, Agostino Depretis e Nicola Amore, era quello di vincere la malattia e la morte, nel popolo napoletano. E allora, per chi abbia anima sensibile questa strada assume un simbolo elettissimo, è l'emblema della solidarietà umana che, dall'alto del trono, del governo dello Stato, del governo della Città, sente la necessità di elevare prima fisicamente e poi moralmente il popolo, dando ad esso i beni primari della vita, la luce, l'aria, la nettezza, la salubrità, dandogli la via e la casa, dandogli il modo di acquistare la sanità del corpo che è la gioia dell'anima, sottraendolo alle infermità, alle degenerazioni, all'epidemia, e sottraendolo, così, anche alla disonestà e al vizio. Questo, nella mente di chi lo volle, dopo la strage del 1884, dopo la visita ai tugurii e alle catapecchie fatta dal Re, dopo l'orrore che ne ebbe l'animo dei maggiorenti, questo era il compito del Rettifilo, che si è chiamato e si chiama Risanamento, con tutto il suo progetto di diramazioni, di colmate, di traverse. Il Rettifilo 
doveva salvare il popolo napoletano: e poichè gli occhi che guardano poco e fugacemente, poichè le labbra che domandano, non sempre sono esaudite da labbra che conoscano la verità, poichè il difetto di cui tutti siamo malati, è la fretta, poichè noi siamo, anche, malati di superficialità, poichè nessuno ha il tempo di fare quel che vorrebbe, nel mondo, poichè nessuno ha la volontà necessaria a eseguire tutto quello che vorrebbe, poichè tutto ci sfugge, per esser profondi, così, noi possiam credere che, veramente, il Rettifilo abbia dato al popolo napoletano tutto quello che gli mancava, e, sovra tutto, lo posson credere tutti coloro che passano qui un giorno o un mese!

$$
\text { * }
$$

Eppure, questa illusione non resisterebbe a una osservazione più minuta. Alla seconda, alla terza, alla decima volta che voi attraversate questa magnifica strada, volgendo gli occhi, a manca, a dritta, lo scenario seducente ha dei grandi strappi. Un imponente palazzo, rossastro, pomposo, si pavoneggia con le sue cento finestre: e, accanto, voi scovrite un vuoto, e un muretto basso si prolunga, si prolunga, un muretto su cui la pubblicità allegramente appende i suoi quadri, da anni e anni, e dietro questo muretto, molto più indietro, sorgono delle masse di case lercie, cadenti, miserabili, di tutte le misure, macchiate di tutte le stigmate della povertà e del vizio. Ciò sparisce: un'altra costruzione moderna tenta ridarvi una parvenza di civiltà, ma, fatto accorto, voi cercate ficcar l'occhio, ai fianchi, alle spalle, e subito dietro, a otto o dieci metri, ecco, di nuovo, un affogamento di topaie, dalle cui finestrette pendono i cenci più indecenti, magari con la poesia del vaso di basilico e del popone appeso al giunco. Così, otto, quindici, venti volte, dalle due parti, ma sovra tutto, a diritta, andando verso la ferrovia, questo sipario lacerato bruscamente, vi mostra degli spettacoli improvvisamente brutti, nauseanti, schifosi: è la cattiva parola, ma è la parola e invano voi tentate di rifare le fila del vostro sogno di una via maestosa e ricca, di una via nobile e purificante, di una via che serva egualmente alla salute, alla fortuna e alla felicità del popolo. Queste continue apparizioni, fra le enormi nuove costruzioni, di quelle immonde costruzioni vecchie, non lontane, vicine, non lontane, accanto, non lontane, alle spalle, vi hanno distrutto tutta la vostra tela d'illusione. Cercate le traverse che dovevano portare da sinistra, dai quartieri più alti al Rettifilo, bonificando la regione che comincia a santa Maria la Nova e continua pei Banchi Nuovi, san Giovanni Maggiore, Mezzocannone, Università, sino all'Annunziata, sino a Capuana, e non ne trovate che due sole, complete, su venti, quelle attorno al Sedile di Porto, e tutte le altre sono abbozzate, sono pezzi di via, di otto o 
dieci metri, con il loro bravo nome, di un qualche nostro illustre cittadino - e anche di voi, o Francesco Serao, o avo mio! - e niente altro, salvo, dopo questi dieci metri, che una cortina di antiche case non abbattute, una cortina che chiude le comunicazioni, che urta lo sguardo. Voi cercate le più belle traverse, quelle che dovevan tagliare a diritta, dal Rettifilo al mare, risanando i quartieri successivamente di Porto, Mercato e Vicaria. Su venti, ve n'è una sola, completa. Alcune altre, quattro o cinque sono come quelle a sinistra, appena cominciate, abbandonate da anni, ottuse, traverse cieche, ove, in fondo, ma non molto in fondo, sorge lo stesso spettacolo, sempre, di case antichissime, mezze dirute, mezze cadenti, nerastre, verdastre, grigiastre.

Dopo, non vi è più nulla. Cioè, vi sono dei vicoletti che precipitano per mezzo di dislivelli paurosi, di scalette ripide, difese da rozze ringhiere, in tutto ciò che sta dietro il Rettifilo, vicoletti sinuosi, vicoletti neri, angoli dove due o tre vicoli s'intersecano dirupandosi, tutto un disegno bislacco e grottesco, accanto, sì, accanto, alle altitudini superbe dei nuovi palazzi. E voi, verso la fine del Rettifilo, vedendo fuggire gli ultimi lembi mirabili della vostra illusione, voi vi domandate se non siate vittima di un'allucinazione, se una parte di quel che vedete non sia falso, poichè troppo forte è il contrasto, poichè non può essere tutto vero, a pochi metri di distanza, il decente e l'indecente, il pulito e lo sporco, la pompa e l'inguaribil miseria, il lusso e la povertà più abbietta. Che cosa è falso, che cosa è vero? Sono, forse il portato di un incubo tutte quelle masse di abitazioni luride, fetide, cascanti, ove pare che si moltiplichino la tristizie e la tristezza, il morbo e il disonore, il delitto e la morte? Sono forse gli spettacoli che vi fecero inorridire, come uomini e come cristiani, venti anni prima, sono questi spettacoli che si rinnovano, falsamente nella memoria, nella fantasia, così, come nei momenti di nostra malinconia spirituale e di nostra debolezza fisica? $\mathrm{O}$, forse è falsa l'altra parte, cioè la parvenza moderna del Rettifilo e i suoi palazzi che vorrebbero essere splendidi, ma che sono almeno, nuovi, netti, solidi, grandi, appartengono al sogno? Non sono forse, un lungo scenario di tela, su cui un abile scenografo abbia dipinto a grandi tratti, una serie di edifici maestosi, e intanto, non si sa come, non si sa perchè, la tela ha delle grandi soluzioni di continuità e lascia vedere l'oscurità, il luridume delle quinte, ove tutto è rancido, è puzzolente, è nauseante? $\mathrm{O}$, forse, non sono di carta pesta, di legno dipinto, queste case, come quelle che estrae, lentamente, da una scatola, la mano di un bimbo e le dispone sovra un piano, ad angoli retti? Non è, forse, a destra, a sinistra del Rettifilo, lo svolgersi di un bizzarro paravento, i cui pezzi non sono 
bene congiunti, anzi sono disgiunti, e il paravento non giunge a nascondere, quel che non si deve vedere?

$$
\text { * }
$$

E passino i vostri occhi ricercatori dalle cose alle persone del Rettifilo, vi passino, per conoscer più presto e meglio il motto dell'enigma. La possente arteria napoletana rifluisce, in ogni ora, di sangue vivido: una folla attraversa costantemente il Rettifilo, a piedi, in carrozza, in trams, specialmente sino a piazza Depretis, andando e venendo dai due rami di via Duomo. Folla di ogni qualità e, talvolta, anche, folla di persone distinte, bene vestite, gli uomini con la catena di oro sul panciotto, le donne con i ciondoli sospesi sul petto. Tutto questo mondo va, viene, ritorna, si allontana, mondo svariato, multiforme, multanime. Se voi siete abituato a discernere i volti e le espressioni, fra la folla, se avete l'ardente e dolente segreto dell'intuizione, voi scorgerete, lungo il Rettifilo, persone e faccie che vi daranno un fremito di sorpresa e, forse, di sgomento. Sugli angoli di quelle viuzze, presso quelle ringhiere, su quel limitare fatidico fra il vecchio e il nuovo, e, persino, nelle poche vie principali e non finite, stazionano sempre degli uomini, sul cui viso la delinquenza è impressa e la cui espressione non mente; stazionano mendicanti dei due sessi e di tutte le età, ma di una mendicità sfrontata e ributtante, e stazionano anche, meno di mattina, molto più nel pomeriggio, moltissimo di sera, le sventurate e sciagurate femmine del popolo, che esercitano il più compassionevole e più atroce fra i mestieri. Così, sull'orlo della superba via, sui due suoi lati, fiancheggiandola, il vizio e la miseria, il delitto mettono la loro popolazione. La gente che passa, è molta, non guarda bene, non bada: ma due, tre volte al giorno, un ladro si slancia sovra al galantuomo, sovra la signora, in pieno giorno, in pieno Rettifilo, fra mille persone, e gli strappa l'orologio, le strappa gli orecchini, il derubato grida, il ladro infila la viottola, si gitta per un angiporto, è sparito, la folla strepita, non vi sono guardie, i mendicanti gridano e una di quelle donne del vizio, dà una falsa indicazione, perchè è, forse, un'amante, un'amica, una sorella del ladro, sempre una complice. Sia a piedi, sia in carrozza, la vittima, il ladro finisce sempre per fare il suo colpo, senza farsi arrestare, liquefacendosi come una nuvola, dietro una di quelle stradette: e alcune, anzi, di quelle vie, hanno la loro fatal rinomanza, come quella a principio del Rettifilo, la via di santa Candida. Dopo le nove di sera, il tratto del Rettifilo da piazza Depretis alla Ferrovia, è poco percorso da gente: e malgrado le 
grosse lampade elettriche, quel tratto è uno dei più pericolosi della città, e i medesimi cocchieri da nolo, affrettano il passo zoppicante del loro povero cavallo, andando alla stazione o tornandone, poichè sanno che il loro passaggiero può avere, forse e senza forse, un'aggressione. In quell'ora non si aggirano, colà, che ladruncoli, camorristi, pregiudicati e donne di mala vita. Nella magnifica strada: nella strada della salute e della redenzione del popolo napoletano!

$$
\begin{gathered}
* \\
* *
\end{gathered}
$$

Ahi, che essa è semplicemente un paravento, ma leggiero, fragile e grossolano paravento, un paravento che non nasconde neppure, a chi vuol saper tutto, tutto ciò che vi è dietro, di pietoso e di orribile! E un'altra volta io vi dirò quel che vidi, lì dietro, con una triste e lunga curiosità, con un coraggio disperato e, con l'angoscia più opprimente, del mio umile ma fedele cuore di napoletana!

\section{DIETRO IL PARAVENTO}

Cominciamo da quanto esiste, dietro il paravento a sinistra del Rettifilo, venendo dal centro della città, andando verso la ferrovia: e osserviamo se si è risanato, come era la idea semplice e alta di tutti quelli che vollero salvare il popolo napoletano dalla sporcizia, dal vizio, dalla epidemia e dalla morte. Questo lato è il meno orribile, quando lo si percorre, passo passo, dalle spalle di via Guglielmo Sanfelice, dalle spalle dello splendido e deserto palazzo della Borsa sino laggiù, laggiù, all'Annunziata. Eppure! Camminando dietro il paravento, salendo, scendendo, salvo due o tre traverse di cui una sola è completata, due compiute a metà, le altre sono semplicemente aperte, e alcune di esse non sono neppure accennate, restandovi ancora, massime verso l'Università i vicoli antichi, umidi, alti, tetri e sporchi. È il lato meno spaventoso agli occhi, meno nauseante all'odorato, quello a sinistra; eppure! Sono restate intatte le oscure e malfide gradelle di Santa Maria la Nova, le antiche gradelle che conducevano al Cerriglio e che ora conducono alla piazza della Borsa; intatte le strette, nere, soffocate, soffocanti gradelle di Santa Barbara, col loro angiporto che avrà duecento anni e che venti anni di risanamento edilizio, a due passi di lì non hanno distrutto, le famose gradelle di santa Barbara, celebri per il loro tarallaro, il biscottaio popolare, ma celebri anche per il vizio diurno e notturno, che vi ha i suoi antri più bassi e più tristi: nè, a quanto pare, tutto questo è mutato. I miei occhi hanno visto, in questa lunga indagine, le donne appoggiate agli angoli di questi angiporti, con le gonne attaccate sullo stomaco, le pianelle coi tacchi alti, le calzette rosse e le guancie cariche di belletto, mentre, nei loro occhi, vi è quella mortale fierezza e quella mortale tristezza che è il 
segno caratteristico del peccato, del vizio, nelle donne del popolo napoletano. Questo è il lato migliore di dietro il paravento, le vie che salgono, vanno verso quartieri più borghesi che popolari, vanno verso quartieri di commercianti, di professionisti, e lo spettacolo non desta un ribrezzo tanto profondo; eppure! Forse che è stato toccato, neppure in una sua pietra, quel budello nero, storto, ripido, sdrucciolevole, che è il vico di Mezzocannone? Ah, esso non è stato toccato, e tutta la gente d'immaginazione, ma senza cuore, tutti quelli che amano il colore a scapito della civiltà e della decenza, tutti quelli che amano il carattere e non hanno compassione di chi muore, si consoli, perchè il vico di Mezzocannone è stato rispettato e, probabilmente, non sarà mai toccato! Eccolo, oscuro, fetido, pericoloso alle gambe, pericoloso alle gonne pulite, ai calzoni puliti, eccolo con le sue case senz'aria e senza sole, con le sue botteghe che sembrano dei sotterranei, ove sono dei tintori, dei venditori di vino e persino, lavorando nella via, delle ricamatrici di oggetti di chiesa, ricamatrici in seta e in oro: eccolo, col suo goffo re di Mezzocannone, sovra una vecchia fontana, con quell'altro precipizio, di traverso, che sono le gradelle di san Giovanni Maggiore: eccolo, il vero nostro vicolo di Mezzocannone, ce lo hanno lasciato e noi possiamo ancora, turandoci il naso, attraversarlo in fretta: il Risanamento non ha osato arrivarvi: non vi arriverà mai!

Sul fronte del Rettifilo si sta costruendo la facciata della nuova Università, nè appare molto bella, mentre l'antica Università, via, aveva la sua grandezza e il suo fascino: si sta costruendo e gli studenti e i professori e la scienza finiranno per esser allogati magnificamente quando tutto ciò sarà finito. E via san Marcellino? E gli altri intestini di viottole che discendono, in quella regione, intestini ove si agita e vive della gente, vi sono degli uomini, dei cristiani, accumulati, così, e tutte le altre straducce, adiacenti al Rettifilo? Tutto ciò che era il vero risanamento, perchè, perchè non è stato risanato, mentre quasi tutti i denari, sono stati spesi, mentre quei pochi che restano, salvati a stento, basteranno scarsamente a completare le due ali del paravento, a destra e a sinistra, e non si potrà nulla fare per tutto ciò che è dietro? Nulla ci sta più a cuore del decoro esterno della nostra carissima città e noi amiamo che ci sia un palazzo della Borsa maestoso, anche se non vi si facciano affari, dentro; noi amiamo vedere la grande gabbia aerea dei telefoni, sull'alto palazzo, in piazza, sebbene siano così pochi gli abbonati in una città di seicentomila anime; noi amiamo pensare una novissima Università, con le sue cliniche e i suoi gabinetti scientifici, affollata dalla parte più geniale e più simpatica della nostra popolazione, cioè gli studenti: sì! Ma che, accanto, a dieci passi, viva nella lordura, nella miseria, nelle stamberghe, nelle caverne, tutta una 
parte di popolo, per cui si volle il risanamento edilizio e igienico, che questa parte di popolo a cui si destinarono cento milioni, muoia di tutte le infezioni, dopo averne vissuto, alle spalle di tutti i nuovi palazzi: questo è che fa sollevare di dolore e di rimpianto il nostro cuore e ci fa sembrare una beffarda ironia la maestà esteriore dei nuovi edificii, dietro i quali vi sono il putridume e la cancrena!

$$
\begin{aligned}
& * \\
& * *
\end{aligned}
$$

Ma la vera via crucis per l'osservatore che abbia un'anima pietosa, è il percorrere, a piedi, dove può e come può, tutto ciò che è dietro il paravento, alla diritta del Rettifilo, venendo dal centro della città, andando verso la ferrovia, principiando da quanto è alle spalle della via Niccola Amore, continuando sino a piazza Mercato, sino a porta Nolana. Alle spalle? Via Niccola Amore, a diritta, non ha che un lungo e basso muretto e tutte le vecchissime case, in cui s'imboccava via Porto, sono in piedi, alte, prepotenti, incombenti, sfidanti da anni il piccone, che non le tocca, che non le toccherà, forse, giammai! Ivi, non vi è neppure il paravento: ivi, signoreggiano, quasi spettri della miseria e dell'onta, tutte le case di Basso Porto ricetti di povertà inaudite, ricetti di delitti e di delittuosi, ricetti di tutte le cose e le persone infami e dolenti. Guardate! Non avete che a guardare alla vostra diritta, passando, e il Basso Porto vi dirà che è stato di vano, di inane, di inutile quanto si è voluto fare e quanto non si è fatto, quanto non si è voluto fare! Ma, abbiate una lugubre curiosità e discendete, laggiù. Dico bene: discendete tutto il lato destro del Rettifilo: le colmate sono restate un progetto fantasioso, mai eseguito onde, laggiù si penetra per tutti i modi più rudimentali, più incerti, più infidi e più pericolosi. Scalette di legno improvvisate e diventate, ahimè, definitive; scalette di pietra, a scalini mal connessi e tremanti sotto il piede; scalette tagliate nella terra, sì, nella terra, come in qualche villaggio africano; rampe a scaglioni; rampe di terra, discese ripide e sdrucciolevoli: tutte le forme, infine, del precipizio, a due passi dai grandi palazzi. Qua e là, qualche rozza ringhiera; appoggiandovisi, guardando giù, par di mettere l'occhio in una cantina, in un pozzo.

Lo slivello fa paura. Le colmate dovrebbero arrivare ai primi piani di queste catapecchie: e a pianterreno, ai primi piani di queste catapecchie, abita gente, ha bottega, vive, muore; e così sarà, per moltissimi anni ancora, così sarà, forse, per sempre! Lo slivello pauroso si prosegue da Porto, a Vicaria, a Mercato, sino alla fine, e in fondo a questi pozzi, in fondo a queste cantine, in fondo a questi sotterranei esiste tutto quello che esisteva prima, purtroppo, peggiorato! Le antiche arti, gli Orefici, gli 
Armieri, i Lanzieri, i Taffettanari, son là, coi loro piccoli opificii malsani, oscuri, miserabili; sono ancora lì le straduccie affogate, fra le case, gli antichi portoncini larghi settantacinque centimetri, le antiche finestre dai vetri sporchi, gli antichi cavalcavia sui quali pare si abbattano le vecchie case crollanti, gli antichi vicoli ciechi, ricovero di ogni sporcizia: tutto, tutto è restato com'era, talmente sporco da fare schifo, senza mai uno spazzino che vi appaia, senza mai una guardia che vi faccia capolino.

Tutto si fa, nelle piazzette, nei vicoletti: tutti vendono il vendibile, erbe, frutta, carne, pesci, nel fango eterno della strada; e vi sono le antiche osterie, ancora, ove si vendono le zuppe di pasta e fagioli, le fritture, di cento cose fritte, dai panzarotti ai peperoni, le insalate di scapece, il zoffritto a porzione di tre soldi, di due soldi, persino di un soldo! Come un tempo! Peggio di un tempo! A dieci passi dal Rettifilo, caldaie di patate, caldaie di polipi, caldaie di spighe bollite, caldaie di castagne, e il più acre odore, intorno, da queste cucine, dalle piccole fucine degli Orefici,e degli armaioli, dalle marmitte dei tintori! Pieno di colore? Già: ma orribile! Io rammento tre punti, fra gli altri. Una piccola regione chiamata Tentella: cioè un intrico quasi verminoso di vicoletti e vicolucci, nerastri, ove la luce meridiana mai discende, ove mai il sole penetra, ove per terra la mota è accumulata da anni, ove le immondizie sono a grandi mucchi, in ogni angolo, ove tutto è oscuro e tutto è lubrico, ove, a un crocicchio, vi è un'ostessa dai folti capelli neri, a un crocicchio, donde, in penombra si vede ancora il fondaco Tentella, una ostessa che vende ogni sorta di mangiare in grandi piatti di rame lucido, dalla fragaglia fritta alla spiritosa di pastinache. E m'incoraggia ad andare verso il fondaco Tentella, l'ostessa, con la bonomia napoletana, m'incoraggia, poichè vede che io esito, innanzi a tutte quelle sporcizie, lungo quelle mura trasudanti umidità, con quegli odori nauseanti: mi incoraggia, mentre io esito, fissando gli occhi in quella oscurità - e siamo nel paese dell'azzurro, del sole! - mentre sul suo viso giallastro, sulle sue labbra violette, nei suoi denti neri, io leggo tutte le traccie di quella vita sprofondata nel lezzo e nei contatti costantemente malsani, tre o quattro persone, in una stanza, e che stanza, e le ore del giorno, in una cucina affumicata, a preparare le vivande male olenti, da vendere! Da quanti anni non viene, qui, un sindaco, un assessore? Da quanti anni non si lavano, queste vie? Da quanti mesi non si spazzano? Tutto il letame delle bestie e delle persone e delle case, tutto è qui e nessuno ce lo toglie, qui, sull'orlo della civiltà novella, dietro ai palazzi sontuosi - andate laggiù, cercate del vicolo Barre: esso dovrebbe corrispondere a una colmata che non si è fatta, a una traversa che non si è mai aperta. È un vicolo strettissimo, lunghissimo, con case altissime, disseminate di balconi, di 
finestrelle: i due lati sono legati fra loro da cavalcavia, da ponti di pietre, da ponticelli di legno, il che ne aumenta l'oscurità: i due lati, anche, sono legati da corde, da funicelle a cui pendono panni, di tutti i colori, rappezzati, stinti: e questo lunghissimo vicolo Barre, i cui portoncini sembrano caverne, non ha un lampione: è una vera sentina di ogni cosa più ignobile: ed è pericoloso a esser attraversato anche di giorno, tutto abitato da donne di mala vita, da camorristi, da ladri, e l'orrore che ne proverete non sarà solamente fisico, voi proverete uno di quegli avvilimenti morali che provocano delle profonde tristezze. E se voi volete scrivere un capitolo di un romanzo popolare, più innanzi, molto più innanzi di questo tremendo vicolo Barre, attraversate il vico dei Cangiani, col suo relativo supportico. Esso è costeggiato, a manca e a dritta, tutto da piccole locande, dove si pagano quattro o cinque soldi per dormire, ove si dorme in quattro o cinque in una sola stanza: queste locande hanno una clientela speciale, quella dei carrettieri di Calabria, di Basilicata, del Cilento, di Terra di Lavoro, coloro che si chiamano nel popolo, vaticali, da viatico, certo: e questi contadini stanno, di giorno, sui portoncini di queste locande da quattro soldi, stanno, vestiti dei loro panni pesanti e di taglio contadinesco, coi loro cappelli di strana foggia, coi loro mantelli, seduti per terra, seduti sovra una pietra, aspettando di rimettersi in cammino. Io ho attraversato questo vicolo, fermandomi a guardare quei volti adusti, immobili di espressione, pazienti sotto le fatiche e sotto i disagi, quelle labbra mute: ho vissuto dei lunghi minuti in questo vicolo nerastro, tutto disselciato, pieno di acque luride, pieno di una melma attaccaticcia, in questo vicolo talmente tetro che sembra una tomba, e, a un certo punto, sono stata presa dal delirio di fuggire, di fuggire, per non vedere più, per non udire più, per non avere più lo spettacolo della più amara delusione, nel mio cuore di napoletana, per non soffrire delle sconosciute sofferenze altrui, da niuno consolate, poichè quella gente vive $\mathrm{e}$ muore, laggiù, alle spalle dei superbi palazzi, ignota, obliata, disdegnata, disprezzata!

$$
\text { * }
$$

E, in ultimo, sapete che è accaduto? Che il popolo, non potendo abitare il Rettifilo, di cui le pigioni sono molto care, non avendo le traverse a sua disposizione, non avendo delle vere case del popolo, è stato respinto, respinto, dietro il paravento! Così si è accalcato molto più di prima; così il Censimento potrebbe dirvi che tutta la facciata del Rettifilo, è poco abitata, e tutto ciò che è dietro, disgraziatamente, è abitato più di prima; che dove erano otto persone, ora sono dodici; che lo spazio è diminuito e le persone sono cresciute; che il Rettifilo, infine, ha fatto al popolo napoletano più male 
che bene! In quell'intrico che va da Porto a Mercato, a Vicaria, si aggroviglia una folla spaventosa; non vi sono che poche fontanelle di acqua e le case, che debbono essere, demolite (?), ne mancano; non vi sono fognature regolari, non vi sono lampioni, poichè il piano stradale, è assolutamente dissestato: tutto ciò che serve alla vita, vi manca. Se una epidemia, lontana sia, dovesse capitarci, impossibile circoscriverla, impossibile dominarla: in quei quartieri farebbe novellamente strage, come venti anni or sono; e i nostri edili nulla ne sanno; e nessuno vuol saperne niente. E quel popolo che è stato tradito, poichè non ha avuto quanto la nazione gli aveva donato, per redimerlo igienicamente e moralmente, quel popolo che è abbandonato, che lo sa, che un po' ne ride, un po' ne sospira, un po' ne digrigna $\mathrm{i}$ denti, questo grande popolo che noi dobbiamo amare, che noi amiamo, perchè ci sentiamo affratellati con esso, perchè anche noi siamo popolo, perchè noi siamo come esso e figliuoli del medesimo Iddio di giustizia e di clemenza, questo popolo non resiste agli antichi istinti, al bisogno di vivere come che sia, al bisogno di vendicarsi di questa società ingrata e traditrice: non resiste alla suggestione del vizio, del male: e giuoca: e ruba: e si vende: e ferisce: e uccide: e colà, di giorno, di notte, appena dietro il paravento, o nel Rettifilo istesso, il crimine, il delitto, si espandono, fioriscono, eterna rampogna, eterno rimorso a coloro che, fedifraghi al Re, ad Agostino Depretis, a Niccola Amore, a Guglielmo Sanfelice, alla Nazione, commossa di orrore e di pietà, mancarono ai patti giurati e ruppero ogni promessa, lasciando il popolo napoletano a languire, a struggersi, a patire, ad agonizzare, nella più profonda ignavia del corpo e dell'anima.

\section{LE CASE DEL POPOLO}

Una delle nobilissime, pietose ma fallaci utopie di tutti coloro che hanno voluto o vogliono salvare il popolo napoletano dalla miseria, dal vizio, dal delitto e dalla morte, è stata, è quella di dare a questo popolo, delle abitazioni fatte per esso. E, difatti, nessuna compassione e nessun ribrezzo più grande che il cacciar il viso a fondo in questi bassi ove vive e mal vive il popolo, in questi bassi che sono già oscuri, oppressi, angusti nelle vie più grandi e che nei vicoli, in cento vicoli, in mille vicoli diventano delle stamberghe sotterranee, quasi diventano degli antri ove si agitano e brulicano le vite umane, piccole, grandi, decrepite. Il basso è una bottega rudimentale, un terraneo, piuttosto, senza finestra, senza cesso, senz'altro sfogo che una porta, talvolta angusta che, d'inverno, deve star chiusa, che, di notte, non può stare aperta; e appena la primavera viene, chi lo abita, si trasporta nella via, sul marciapiede, vivendo sulla soglia, fuori della soglia, occupando il terreno pubblico, coi suoi figli, col suo fornello 
da stirare e da cucinare, con la sua macchina da cucire, quando non la occupa col suo banchetto da ciabattino, col suo banchetto di venditrice di castagne e di spighe allesse. Nel basso dormivano - dormono! - tre, quattro, sino a sette persone e nelle notti estive, due, tre di essi, soffocando di caldo, trascinano uno strapuntino fuori della porta, mettono una sedia, o addirittura si gittano sul lastrico, dormendo all'aria aperta. Non essendovi cessi ognuna di queste persone, grandi e piccole, va a scegliere un angolo remoto, vicino o lontano, di cui forma il proprio water closet e, talvolta, le madri accompagnano i piccini e le piccine, apposta, perchè non siano disturbate: così, molte strade di Napoli sono trasformate, appunto in water closet di padre in figlio, immancabilmente, senza che questa barbarie indecente, oscena possa essere sradicata. Io citerò e mi si perdoni l'insistenza brutale ma necessaria - la salita della Paggeria, le rampe di Brancaccio, e ahimè, purtroppo, l'elegantissimo parco Margherita, e le squisite traverse Partenope, donde si scopre tanto divino paesaggio di mare e di cielo, sono anche destinate a tale uso. Io ho nominato solo quattro o cinque vie, perchè esse appartengono, è triste il dirlo, ai quartieri più civili di Napoli, cioè di san Ferdinando e Chiaia, poichè, essi appartengono al famoso rione della Beltà, cioè dove abita la nobiltà e dove vengono a dimorare i forestieri. Delle viottole e viuzze ammorbate, ammorbanti dei quartieri popolari, non parlo; dovrei nominarne a centinaia. Ciò è immondo; ma è la verità. Or dunque, ogni salvatore di Napoli, tutti i salvatori di Napoli hanno pensato, hanno detto: diamo al popolo napoletano delle case al primo piano, al secondo, al terzo, al quarto, delle case piccole, pulite, con la cucinetta, col rubinetto di acqua del Serino, col cesso; diamo loro delle case ove entri l'aria, entri il sole, ove ci si possa lavorare ampiamente, bere in abbondanza, e ove la primissima decenza, la primissima igiene siano rispettate. E ciò è stato fatto; e tre o quattro grandi o piccoli quartieri di case pel popolo sono sorti, e ciò è stato fatto con tale imprevidenza, con tale ignoranza presuntuosa, con tali calcoli sbagliati, che questi quartieri non sono serviti a nulla, a nulla, e sorgono, nei sobborghi della città, sulla riva di santa Lucia, enormi, massicci, brutti, già lerci, già quasi cadenti, mentre il popolo non vi abita!

Citiamo il Borgo Marinai, a santa Lucia, posto che si dovevano abbattere, sino da venti anni, tutte le case pittoresche e sporchissime dell'antico rione santa Lucia, case che, oh ironia, si vanno abbattendo solo da un anno, e si era preoccupati dove si sarebbero allogati quei pescatori di polipi, quelle venditrici di acqua sulfurea, quegli intrecciatori di nasse, quei sommozzatori o palombari, si pensò e si costruì, sulla lingua di terra che parte dalla sinistra, di Castel dell'Uovo, un gruppo di casette a un piano, 
sulla riva del mare. Costavano, costano diciotto lire, una stanzetta con la cucina, e ventisette lire due stanzette con la cucina. Irrisione! Nonsenso! Non vi è pescatore, non vi è palombaro, non vi è barcaiuolo di santa Lucia che guadagni più di venticinque o trenta soldi al giorno e volete che ne spenda diciassette soldi, al giorno, solo per la casa? Non vi è venditrice di acqua minerale, di noci, di frutta fracide, di ciambellette, di spassatiempo che guadagni, quando li guadagna, più di dodici o quindici soldi al giorno e, se è sola, se è vedova, se è abbandonata dal marito, come potrebbe pagarne diciassette, al giorno, per il pigione di casa? In breve: come era naturale, non un solo luciano, non una sola luciana è andata ad abitare al Borgo Marinai. Non uno, una! Hanno preferito, ostinatamente, le loro vecchie, dirute, sudicissime case che, per diciotto anni, hanno aspettato il piccone, ove pagavano nove o dieci lire il mese, di pigione - è TUTTO ciò che può pagare il popolo napoletano NOVE o DIECI LIRE il mese! - e negli ultimi due anni, man mano si sono ritirati più indietro, nelle medesime catapecchie, e scacciati dalle demolizioni, sono rientrati, rientrano la notte ad abitare le rovine, e si gittano alle ginocchia dei demolitori, per non essere perseguitati dalle guardie, dai carabinieri, e piangono, e gridano, e urlano, non vogliono andar via, non sanno andar via, e alcuni di essi, o pietà grande, abitano, adesso, nelle grotte onde è forato il monte Echia che sovrasta santa Lucia, e talvolta una di queste grotte frana sulle teste, sui corpi di questi miseri luciani che dormono, e li uccide. Intanto dirimpetto, sotto il forte Ovo, il Borgo Marinai scintilla di lumi che si riflettono nelle acque del mare. Chi vi abita, chi vi vive, mai? Pittori che scelsero quei quartini per istudio, poichè il posto è pittoresco; qualche loro modella; delle ballerine o delle chanteuses del vicino cafè chantant dell'Eldorado, che prendono in affitto, per un mese, per quindici giorni, una cameretta con cucina; qualche donnina di facile vita e misera fortuna; e altra minuta gente, non del popolo. In quanto alle botteghe, esse in un vasto angolo, sono tutte trasformate in osterie grandi e piccole, alcune carissime, altre modeste, altre vere taverne e vi si aspira un'aria mefitica di cucine più o meno malsane, e nel piccolo porto cadono tutti i detriti di queste taverne e ciò contrista, affligge, avvilisce i due eleganti clubs dei canottieri che sono sulla riva accanto. A ogni modo il Borgo Marinai è vivido, lieto, curioso: e inutile, infine, anche al santo scopo a cui serviva. I luciani sono d'altra parte respinti di stamberga in stamberga, respinti di rovina in rovina, di grotta in grotta. E dopo, quando tutto, tutto sarà demolito dove andranno questi superbi ma poverissimi popolani, quelle fiere, ma miserissime popolane dove andranno? Lo sa Iddio! 
Anche le case del popolo costruite all'Arenaccia, nel Quartiere Orientale hanno fallito completamente la meta. Il minor prezzo di ognuno di questi quartini, è ventisette lire il mese; si domandano due mesate anticipate, per regolamento, cioè cinquantaquattro lire: o si domanda un garante solido. Anzi tutto, dove è mai un vero popolano che possa pagare ventisette lire il mese, di pigione? Per poter cavare questa somma, un napoletano del popolo deve guadagnare almeno due lire e cinquanta al giorno, o tre lire: e allora, qui da noi, non è più un popolano, è già un operaio, ma di quelli fortunatissimi, di opera eletta, diciamo così: è già un civile, è già appartenente alla piccola borghesia. Dove, dove è il popolano che disponga, mai, nella sua vita di cinquantaquattro lire tutte insieme? Dove, dove è il popolano che trovi un garante solido? Ah che nessuno, nessuno si convince che qui, il popolo nostro, vive di soldi e non vive di lire, che gitta la sua gioventù, la sua salute e la sua forza in fatiche compensate irrisoriamente, felice, anche, di trovarla, questa fatica; che, per istinto, poichè nessuno pensò a educarlo, preferisce spendere i suoi soldi più nel mangiare, che nell'aver una casa e delle vesti e che quando ha venti soldi, quindici, almeno, gli servono pel suo pranzo e il resto, pel resto! Ventisette lire il mese! Cinquantaquattro lire di anticipo! Un garante solido! Quale ironia insultante! Nelle case del popolo, all'Arenaccia, nel Quartiere Orientale non abitano, dunque, che gli operai eleganti, diciamo così, e tutta la piccola borghesia, piccoli impiegati, commessi, contabili, uscieri, scritturali e, persino, dei cancellieri di tribunale: non abitano che tutti coloro, il cui bilancio familiare fluttua da settantacinque lire a cento lire il mese, posizione, già molto brillante, in questo nostro paese. Borghesia, borghesia minuta, modesta, innumerevole come le stelle del cielo e le arene del mare, borghesia lavoratrice, onesta, ma, come si vede, molto povera, per la sua condizione: borghesia, non altro che borghesia, nelle case del popolo, ma niente popolo, mai! Vi è di più. Spesso, a questi operai fortunati, a questi oscuri borghesi dalla decente miseria, è impossibile pagare ventisette lire al mese, perchè vi sono spesso, cioè, non spesso, sempre, dei figli, e spesso, quasi sempre molti figli, poichè la fecondità femminile, la prolificazione, sovra tutto in certe classi, assume proporzioni assai patriarcali, ma, anche, terrificanti. E allora si trova il rimedio peggiore e migliore; sono due le famiglie che prendono in affitto la casa di ventisette lire, stringendosi, stringendosi, mettendosi in tre, in quattro in una 
stanza, avendo la piccola cucina comune e allora, addio aria, addio luce, addio igiene! Spesso una famiglia subaffitta una camera a studenti, a uomini soli e la vita è comune e tanto nel primo, come nel secondo caso l'agglomerazione, i contatti, il vivere gli uni sugli altri, conduce, novellamente, alla sporcizia, alla malattia, al vizio, alla corruzione e alla depravazione. In quei nuovi caravanserragli, laggiù, laggiù, in questi caravanserragli già tutti deturpati, dall'aspetto già sconquassato, dalle macchie di sudiceria trapelanti dai muri, dai vetri già appannati e dalle cui finestre, come nei quartieri antichi, pendono le biancherie di dubbio colore, mal lavate, e i mazzi di pomidoro e i mazzi di agli, in questi derisorii caravanserragli che dovevano servire alla rigenerazione fisica e morale del popolo napoletano, si svolgono, ogni giorno, drammi dolorosi venuti, appunto, dalla povertà e dalla degenerazione, si svolgono farse grottesche e si vive colà, male, malissimo, come si viveva altrove, e per una folla che, per abnegazione, per virtù naturale, per onestà natia conserva la decenza dei costumi, ve ne è un'altra che ha trasportato, colà, tutti i suoi istinti indomabili, indomati, che niuno ha cercato di domare, che ha impiantato, colà, una novella vita brulicante e scostumata come nei vecchi quartieri, che, infine, se pure non ruba, se pure non assassina, altri essendo i covi e le caverne del ladri e degli assassini, mette, accanto alla folla borghese e decente, una nota di più bassa borghesia, indecente, rumorosa, screanzata, villana, repugnante. Non popolo, non popolo! Il popolo napoletano è restato nei suoi bassi dei vecchi quartieri, nei suoi bassi dei quartieri non risanati, nei bassi purtroppo, del Vasto, dell'Arenaccia, del Quartiere Orientale; non è mai salito, in nessun posto, di Napoli antica, di Napoli nuova, al primo piano o all'ultimo piano, perchè non può pagare $\mathrm{i}$ prezzi, anche minimi che vi si pagano, perchè chi ha costruite quelle case non sapeva niente, ignorava tutto e, intanto, ha fatto una ottima speculazione, poichè tutte quelle case sono affittate, come ho detto; ma lo ripeto, e lo ripeterò sempre, il popolo napoletano non si è mosso dal suo basso, dovunque il basso si trovi, sia una bottega quasi pulita o sia un buco oscuro e insalubre.

$$
*
$$

Così, purtroppo, tutte le grandi idee dei grandi uomini, tutti i vasti progetti, a base di milioni, tutte le intraprese colossali, che volevano il risanamento igienico e morale di Napoli, bisogna dirlo hanno fatto fiasco. E non vi è rimedio, dunque? Non vi è altro da fare? Nulla, proprio, di fronte a tante tristezze, a tanti disastri, a tanti pericoli sociali? Chi sa! Vedremo! 


\section{CHE FARE?}

Se io leggo giornali, opuscoli, libri che si occupino delle grandi questioni napoletane, se io seguo il movimento delle sue associazioni, se io noto i voti dei congressi, se io odo i lamenti degli albergatori, non veggo da tutto questo che una costante, nobile, ammirevole ed esclusiva preoccupazione di rendere gradito, sempre più, il soggiorno di Napoli, ai forestieri. Benissimo! Ottimamente! Tutti gli sforzi per attirarvi quì, oltre che per il fascino di un indescrivibile paesaggio, oltre che per la dolcezza di un clima soavissimo, per la civiltà e la grazia dell'ambiente, il grande mondo cosmopolita, che tante delizie trova, in inverno, al Cairo e a Nizza, tutti questi esemplari sforzi, fatti non solo per attirare, ma per trattenere quì, fra noi, la ricchissima ed elegantissima società internazionale, sono degni del più grande e profondo incoraggiamento. Sì, formiamo il rione della Beltà, ove, sulle sponde del mare, dal primo angolo di Santa Lucia Nova a Mergellina non sieno che belle case, floridi giardini, magnifici alberghi, botteghe di cose di arte: facciamo che queste vie sieno spazzate bene, due o tre volte al giorno, e che il lastricato non costituisca un pericolo per le ossa dei forestieri: otteniamo che le carrozzelle sieno meno sgangherate, i cocchieri meno laceri e meno sporchi e, sovra tutto, meno avidi e screanzati coi forestieri: compiamo il miracolo di fare sparire i mendicanti schifosi, i venditori ambulanti odiosi, i fiorai petulanti e tanti altri individui anche più bassi, anche più equivoci da questo rione della Beltà: e che i capitalisti costruiscano un kursaal a santa Lucia, aperto in inverno per gli stranieri e in estate per i provinciali: e altri capitalisti facciano un Palais de la jeteè alla rotonda di via Caracciolo, bello e ricco come quello di Nizza: e vi sieno altre attrattive più larghe e più possenti, i cui progetti noi lo sappiamo, fervono nella mente di coloro che amano Napoli: e, su tutto questo, si strombetti ai quattro venti della stampa dei due mondi, che la salubrità e la igiene di Napoli sono diventate di prim'ordine, il che è la verità, si strombetti che la sua mortalità è bassissima di fronte a quella di tante altre capitali europee e di Nizza e del Cairo, sovra tutto, il che è la santissima verità; si strombetti, poichè nessuno lo sa, all'estero, che la sua acqua di Serino è la migliore di tutte le acque europee, come è dichiarato in tutti i bollettini sanitari, con l'analisi alla mano e che non vi è bisogno, quindi, di ricorrere, per gli stranieri, a tutte, le acque minerali che bevono altrove, dalla Saint-Galmier all'Apollinaris, e che domandano anche qui, perchè ignorano il Serino: e in ogni maniera, in ogni forma, si raddoppi, si triplichi il movimento dei forestieri a Napoli, si 
renda loro il soggiorno così piacevole qui, da trattenerli giorni e settimane, da imprimere nel loro animo, partendo, una nostalgia invincibile, in modo che, lontani non potendo essi tornare, mandino da noi i loro parenti, i loro amici, le loro conoscenze. Questa è opera civile questa è opera bella, anche se confini troppo con la reclame industriale, anche se abbia troppo l'aria di una speculazione, anche se tenda a trasformare sempre più in un enorme Palace, tutta la Napoli che sale, laggiù, dal mare sino alle colline fiorite di Posillipo e del Vomero! Quel che si è fatto a Nizza e a Montecarlo, ha formato la fortuna di tutta la Cornice da Mentone a Hyères quel che si è fatto al Cairo, ha formato la fortuna di tutto l'Egitto: sia,

sia, questa opera buona, questa opera santa, e in questo paese così bello e così povero, così affascinante e così pieno di miseria, in questo paese così delizioso e dove si muore di fame, in questo paese dall'incanto indicibile, si dia alla industria del forestiero la forma larga, felice, fortunata, che porti, a Napoli, il solo modo di far vivere centinaia di migliaia di persone!

Ma si permetta a un'anima solitaria e ardente di passione, pel suo paese, come è la mia, di chiedere una parte di tutto questo, una povera, piccola parte per migliorare le condizioni igieniche e morali del popolo napoletano. Non si chiedono milioni, poichè i milioni hanno fatto fiasco nell'opera del Risanamento, e nessuno, naturalmente, vuol dare più milioni, quando i primi sono stati spesi male o perduti, per fatalità quasi che una mano misteriosa perseguitasse questo buon popolo nostro.

Si chiedono, in nome di quel Dio giusto che volle fossero accolti tutti i poveri, nel suo nome, povero e vagabondo egli medesimo, sulla terra, che alla redenzione fisica e spirituale dei poveri un po' di attenzione, un po' di denaro, un po' di cura sia dedicata da coloro che debbono e possono fare questo! Tutto deve esser fatto con modeste ma tenaci idee di bene, con semplici ma ostinati rimedii, con umili ma costanti intenzioni di giovare. Bando alla rettorica sociale, bando alla rettorica industriale, bando alla rettorica amministrativa, quella che viene dal Comune, la peggior rettorica perchè guasta quanto di pratico, di utile, di buono si potrebbe fare, dagli edili nostri. Perchè dunque non si obbligano la società dei nuovi quartieri al Vasto, all'Arenaccia, al Quartiere Orientale, di ridurre al minimo possibile le pigioni, in modo che le case fatte pel popolo siano abitate proprio da esso e non dalla piccola borghesia, in modo che ogni stanza non costi più di nove o dieci lire e non vi possano per regolamento stare più di due o tre persone, 
quando vi sono bimbi? Si tenti questo! E se ciò non basta, in tutte le nuove costruzioni sia nei quartieri popolari sia nei quartieri più aristocratici, perchè non si obbligano, con legge, con regolamento, ad avere un piano dei loro palazzi, l'ultimo, fatto in modo che la gente del popolo vi possa abitare, avendo delle stanze, delle soffitte, ciò che si chiama il suppenno che non costino, appunto, più di nove o dieci lire al mese ogni stanza? E se qualche società ancora, qui, vuol costruire sulle colline, o sulla spiaggia, verso la ferrovia o verso il mare, perchè non la si obbliga, per legge o per regolamento, se vuole tale concessione, a costruire al quarto o al quinto piano, tali stanze, a cui si accederebbe dalle scale di servizio? E nei conventi che il Municipio oramai possiede in gran numero, da cui sono state discacciate tante sventurate monache perchè albergano solo dei grandi elettori o dei servitori di consiglieri comunali? Perchè, poichè le povere monacelle furono buttate fuori alla strada, alla miseria e alla morte, non si fa una spesa, una santa spesa per pulire, per restaurare, questi numerosi monasteri e non si affittano, quelle stanze, diventate nette e salubri al popolo napoletano? Un poco di questo denaro che dovrebbe servire, per chiamar qui gente, dall'Europa e dalle Americhe, pochissimo di questo denaro dedicarlo, saviamente, mitemente ma costantemente, a creare delle modicissime, modestissime non case, ma stanze, stanze per il popolo!

$$
\begin{gathered}
* \\
* *
\end{gathered}
$$

E qualcuno di quei vividi lampioni a gas che splendono nel Rione della Beltà, perchè non metterlo laggiù, anche meno splendido, ma lampione, ma acceso, dietro il paravento, dietro i famosi palazzi del Rettifilo, alle cui spalle, nella notte, si ruba, si commettono infamie e si uccide, nelle tenebre profonde e paurose? Perchè non dare un poco di luce, proprio un poco, perchè non si possa più nè rubare nè uccidere, almeno in alcune di quelle vie? Non è un dovere stretto, rigoroso, di qualunque municipio, di dare la luce, di sera, di notte, ai cittadini? Questo rigorosissimo dovere, perchè non si compie, in favore del popolo napoletano, dai due lati del Rettifilo, da Porto a Pendino a Mercato a Vicaria? L'idea semplice: qualche lampione, o edili nostri! E di questa schietta fresca, spumante acqua di Serino, vanto di Napoli, salvazione di Napoli, lavacro interiore, lavacro esteriore perchè laggiù, dietro il paravento, non vi è, pare, neanche la conduttura? Questo supremo beneficio che tanto è costato non era, non deve essere fatto solamente per il volto e per il ventricolo dei ricchi, forestieri, o non forestieri, dei borghesi, piccoli o grandi, ma chi lo volle, questo beneficio profondo dell'acqua, lo 
volle soprattutto per il popolo e il popolo non lo ha, dietro il Rettifilo, non lo ha, o lo ha scarsissimo e beve e si lava nell'acqua verminosa dei pozzi e delle cisterne: e in un modo qualunque, provvisorio, semi provvisorio, definitivo, come meglio si può, bisogna darla, darla questa buona acqua ai quartieri popolari e non servirsene solo per innaffiare la passeggiata di via Caracciolo! E qualcuno di quegli spazzini che dovrebbero rendere nitido come il cristallo il rione della Beltà, dopo aver spazzato questo rione, discenda dove non è mai stato, dove non si spazza mai, e scrosti, tenti di scrostare il sudiciume annoso, e trasporti via, oggi superficialmente, domani meglio, fra un mese completamente, i cumuli invecchiati e putridi d'immondizie. Vi sia un piccolo, piccolo servizio di spazzamento, laggiù, appaia la scopa, appaia il carretto, si compia il dovere oscuro ma preciso di nettare le vie, alla meglio, come si può, ma in qualche modo, ma ogni giorno!

E qualcuno di quei gloriosi militi municipali che debbono tener lontani i pezzenti, i mendicanti, i fiorai, per non seccare gli stranieri della Riviera e del Chiatamone, penetri, penetri laggiù, e applichi le leggi di polizia urbana, laggiù ove non vi è traccia di tutto questo, laggiù ove ognuno fa quello che vuole, perchè niuno s'incarica di fargli fare quello che deve! E i militi della questura non si occupino solo a vegliare nei quartieri aristocratici che i cocchieri non vessino i viaggiatori del Grand Hotel e del Bertolini, ma qualche milite di essi si occupi a impedire, possibilmente, il vizio, l'infamia e il delitto nei quartieri popolari, dietro il Rettifilo!

\section{$* *$}

$*$

Che chiedo io, infine, per i miei fratelli del popolo napoletano, che chiedo io come tutti quelli che hanno cuore, e anima, salvo che finisca l'oblio e l'abbandono? Che chiedo io, in nome dell'eguaglianza umana e cristiana, salvo che il popolo di laggiù sia trattato come tutti gli altri cittadini, abbia una casa, abbia della luce, nella notte, dell'acqua, della nettezza, della sorveglianza, sia guardato e protetto contro sè stesso e gli altri? Che chiedo, io, se non l'applicazione della legge umana e sociale, trattar quelli come si trattano gli altri, dar loro quel che spetta loro, come esseri viventi, come cittadini di una grande città? Faccia il suo dovere chiunque, non altro che il suo dovere, verso il popolo napoletano dei quattro grandi quartieri, faccia il suo dovere come lo fa altrove, lo faccia con scrupolo, lo faccia con coscienza e, ogni giorno, lentamente, costantemente, si andrà verso la soluzione del grande problema, senza milioni, senza società, senza 
intraprese, ogni giorno si andrà migliorando, fino a chè tutto sarà trasformato, miracolosamente, fra lo stupore di tutti, sol perchè, chi doveva si è scosso dalla mancanza, dalla trascuranza, dall'inerzia, dall'ignavia e ha fatto quel che doveva.

\section{L'ANIMA DI NAPOLI}

\section{L'ONORE}

Malinconicamente assiso presso un desco, nella famosa Osteria della Giarrettiera il grosso cavaliere Falstaff rumina il malizioso e audace affronto fattogli dalle allegre comari di Windsor, che lo hanno sepolto in un canestrone, sotto una montagna di biancheria sporca e lo hanno calato nel Tamigi. Con un enorme boccale di vino caldo, egli cerca di riscaldare il suo povero stomaco, gelato dalle acque del fiume: con filosofiche meditazioni, fra ciniche e dolenti, egli cerca di rinvigorire la sua anima depressa. Beve, Falstaff, un largo sorso del suo grog e dice con un sorriso amaro: «L'onore? Che cosa è mai, l'onore? È forse, un giustacuore l'onore? È un pajo di stivaloni, l'onore? Si mangia, l'onore? Si beve, forse, l'onore? Che ne fai, tu, dell'onore? Si batte, moneta, forse con l'onore? Di quale onore, tu parli? Del mio? Del tuo? Il mio è diverso dal tuo! L'onore? Una parola: un soffio, veramente, non altro che un soffio.» $\mathrm{E}$ crolla le pingui spalle, bevendo ancora e con la mano quadrata che posa il gotto, fa un cenno per diradare questo soffio che è l'onore, dalla sua vita di beone.

Falstaff, colui che, giovine, era stato paggio del duca di Norfolk ed era in giovinezza, tanto sottile da passare dentro un anello, colui che era stato l'amico di Harry Plantagenet, principe ereditario e poi re d'Inghilterra, Falstaff, diventato cinquantenne, obeso, calvo, poltrone, goloso, mangione, ubbriacone, dissoluto, pieno di spirito, pieno di risorse, lesto di mano, imbroglione famoso e pure piacevole, non mancante di chic, Falstaff, osa dire, in quel tempo, tutto il suo pensiero sull'onore. Egli ha tutti i vizî, salvo quello immondo della ipocrisia; egli è capace di coprirsi di tutti i crimini, ma non di fingere la virtù: egli vive di ogni porcheria, ma lo dichiara, non può fare altrimenti, che commetter frodi e ladrerie, visto che deve vivere, mangiare, bere, vestirsi, infine! Il grande William, è così sincero, così umanamente sincero e persino brutale nelle sue creature di verità o di vita! Dal momento che, con l'onore, Falstaff non può aver nè un abito, nè un pajo di scarpe, nè un boccale di claret, nè un'oca farcita, nè un vasto letto per rotolarvi la sua colossale persona, egli dichiara apertamente che ci rinunzia, all'onore e che disperde questo soffio vano della sua esistenza. Altri tempi! Chi 
oserebbe mai dir questo, ora, con tutte le levigature, le lustrature e i seize reflets della società moderna? Quale cinico fra i più cinici finanzieri moderni, o quale celeberrimo avventuriero farebbe mai il proclama di Falstaff? Chi mai rinnegherebbe l'onore, con tanta filosofia crudele come il ventruto cavalier di ventura inglese? Altri tempi! Tanti,probabilmente, pensano come egli pensa, anche adesso; tanti come Falstaff, nel segreto del loro spirito, sono convinti che non battendosi moneta, con l'onore, e la moneta, essendo non solo utile, ma necessaria è meglio rinunziare tacitamente a questo vano soffio dell'onore: tanti, e sono, forse, i meno numerosi ma i più temibili, hanno cominciato per fare il glaciale e mortale ragionamento di Falstaff, anche prima di entrare nella lotta della vita. Altri tempi! La superficie umana è mutata: tutta l'apparenza sociale è diversa: e Falstaff, grasso o magro, fine paggetto gentile o grosso capitano di ventura, può sempre sviluppare i suoi istinti, sotto ogni forma delle più alte e delle più basse, ma niuno gli udrà mai dire che l'onore è un soffio e che non si fa denaro col vento.

$$
\begin{gathered}
* \\
* *
\end{gathered}
$$

Noi, però, abbiamo una idea solitaria. Contrariamente a quanto si agita in fondo alle coscienze attaccate dal tarlo del bisogno, minate dal desiderio di ogni ricchezza e di ogni potenza, in opposizione a questo comodo e facile cinismo segreto, noi crediamo che l'onore non sia una parola, non sia un soffio vano e che non sia nè bello nè utile fare un gesto, con la mano, e scacciarlo dalla propria vita. Noi crediamo di più: cioè che, con l'onore, si possa anche batter moneta. Ci riesce impossibile di credere che solo i furfanti, solo i ladri si possano arricchire, nella società; accade, questo è vero: accade troppo: ma, dall'altra parte, di fronte a tutta la gente di coscienza ambigua, di carattere equìvoco, di tendenze losche, di fronte a tutta la gente che farebbe ogni cosa, pur di arrivar a tutto, $\mathrm{i}$ nostri occhi mortali ne veggono molt'altra che, quìetamente, austeramente, compie la sua parte, nel mondo, crea la sua fortuna e quella altrui senza mancare all'onore. Di fronte a organismi finanziarî che assidono la loro sorte sovra i mille calcoli più sottilmente ingannatori e di cui ogni manifestazione economica rappresenta un marchè de dupes, di fronte a queste compagini che, ormai, si fanno sempre più rare, nel mondo, altre ne vediamo sorgere, prosperare, fra noi, in Europa, lontano, dapertutto, in cui ogni atto è regolato dalla onestà commerciale, dalla lealtà industriale. Per chi vede il minuto presente, per chi sa guardare verso l'orizzonte, verso l'avvenire, può sembrare, forse, che l'onestà sia una cattiva speculazione e che un galantuomo rimanga povero: così è: ma 
non per tutti: ma non per molto tempo: ma il galantuomo o finisce per vincere il suo orribile destino, o costudisce, come un tesoro, la sua perfetta reputazione. Con l'onore si batte anche moneta, per grazia di Dio! A centinaia, a migliaia ci confortano in questa fede piuttosto solinga ma salda, gli esempi particolari, gli esempi collettivi, in cui la probità, la integrità, la rigorosa scrupolosità furono la sorgente di fortune individuali e di fortune sociali veramente possenti; da ogni lato della terra, nei libri, nei giornali, nelle cronache, nella vita, germogliano queste istorie di prosperità talvolta colossali, basate solo sul lavoro, sulla volontà, sull'intelletto, ma basate, sovra tutto, sulla onestà personale o collettiva. Era naturale al pancione di Windsor, cui giovava restar seduto sotto la pergola della taverna, bevendo vino aromatizzato e giuocando a dadi, di dir che l'onore non vi porta le aune di velluto per far un giustacuore o non paga il conto dell'osteria: è comodo agli ambiziosi moderni pensare fra sè che l'onore non si tramuta in cheques, in palazzi marmorei, in equìpaggi smaglianti, in gallerie di quadri e in collezioni di giojelli. È comodo: ma è falso. Chiunque ha scritto, scrive, o scriverà la storia della ricchezza, la storia dei ricchi, dica se non è falso: e che paesi, società, uomini, mille volte, centomila volte partirono dalle più umili volontà di bene e di onestà per giungere ai più bei fastigi della fortuna, senza aver traviato, giammai.

Pensino questo, coloro che, oggi, si adunano, non senza solennità, questi deputati di Napoli, ardentemente desiosi di fare il bene della loro città. Lo pensino: non lascino vacillare un solo istante, la loro coscienza di galantuomini: non manchi loro un solo momento la fiducia nella probità umana, su cui la loro vita si è formata e ha trovato la sua formola. Essi vogliono, i deputati napoletani, la prosperità larga della metropoli mirabile che, dotata di tutte le bellezze, è ancor povera e triste; ma vogliono la sua prosperità insieme all'alto rispetto del suo onore. Sia, sia anzi tutto, l'onore: anzi tutto che coloro i quali saranno i prescelti, per sedere sulle cose del Comune e che, prescelti, saranno additati al voto popolare, abbiano per insegna del loro nome, la specchiatezza del loro carattere: anzi tutto che, dinnanzi all'Italia, dinnanzi all'Europa, ovunque il nome di Napoli sia pronunciato, sia, oramai, per il decoro, per la coscienza di chi la rappresenta, unito a quello della più bella dignità civile: anzitutto che, per convinzione, giammai più il sospetto, l'accusa, la delazione possa colpirla: anzitutto che ovunque esso sia, l'uomo onesto, intelligente, attivo, fattivo, sia il suo lavoro dato a Napoli, giovandole con tutte le sue forze. Quando ciò sia organizzato, con sapienza, con 
larghezza, prendendo coloro che dovranno essere i futuri amministratori, dovunque si trovino galantuomini e uomini capaci, senza fare viete questioni di partito, di colore, roba vecchia, roba distrutta: quando ciò sia un fatto compiuto, l'onore di Napoli, che si va lentamente ricostruendo, ma con sicurezza, questo onore di Napoli servirà anche a batter moneta,. Quando i capitalisti dell'estero, del nord, sapranno che, contro ogni ostacolo, Napoli ha voluto per suoi magistrati, comunali, i migliori suoi cittadini, quando gli uomini di finanze di tutti i paesi, di tutte le regioni, sapranno che, quì, il sentimento della probità sociale si è rifatto, nelle persone, nelle cose e nei costumi: quando gli industriali di ogni dove, comprenderanno di poter avere fiducia; allora, sì, che ogni piccola o grande pianta della fortuna pubblica, nascerà, germoglierà, fruttificherà in questo suolo fecondo, in questa terra di anime belle. Tutto si farà, quì, dal momento che il buon nome napoletano, che, il decoro della sua cittadinanza, che, tutto il suo onore, infine, sia esaltato: tutto sarà così facile, così semplice, così naturale che il mondo si stupirà. E nell'onore, in questa potenza tutta morale, in questo elemento più puro e, diciamo, più etereo della coscienza sociale, Napoli ritroverà la sua vita, la sua fortuna, la sua ricchezza!

\section{IL RIONE DELLA BELLEZZA}

Una delle cose più amenamente false, che si dicono, si ripetono, si sostengono, per Napoli è la profonda miseria del suo Comune, è la mancanza della lira e del soldo per tirare avanti: una di quelle leggende bizzarre, grottesche, e ingiuriose che moltissimi illustri e oscuri cittadini nostri si compiacciono, dappertutto, di confermare; che le prove più singolari e più fantastiche. Sapete? Non vi è un centesimo per aprire una scuola: il Municipio può a stento, pagare i suoi maestri e le sue maestre. Sapete? Non vi sono che quattromila lire l'anno, per ripiantare di alberi i giardini pubblici e la Villa, quìndi, deve conservare, verso il mare, quell'aspetto di orto devastato. Sapete? È impossibile che si colmino i buchi perigliosi nel basolato di via Chiaia: vi dovete rompere il collo: i basoli costano troppo, bisogna aspettare il bilancio dell'anno venturo: allora, si vedrà. Di questo passo, ogni volta che il Municipio deve cavare cinquanta centesimi, si risolleva la leggenda della mendicità cui è ridotto, accattone che nessun ospizio può ricevere, oramai, più: e, su queste bugiarde apparenze, su queste frasi fatte, da cui la folla si fa così comodamente governare, nessuno si accorge che, al Municipio, piano piano, con aria di nulla, i milioni presenti e futuri, ballano una ridda che, ogni giorno, diventa più vivace. Chi mai oserà sostenere, se ha occhi e orecchie, che il Municipio di Napoli è povero, quando ha messo in discussione, da uno o due anni, delle somme enormi, ora 
per una cosa, ora per l'altra? Chi mai potrà continuare a dir questo, quando, man mano, si verranno esaminando tutti i progetti che sono sul tappeto e, ognuno di essi, costa molte centinaja di migliaja di lire e qualcuno dei milioni? Chi sosterrà, ancora, che non vi sono quattrini per gli asili, per le scuole, per i giardini, per lo spazzamento, per l'innaffiamento, quando sono alle porte un sacco di castelli in aria, tutti uno più costoso dell'altro? Chi dichiarerà esservi ben pochi milionari a Napoli, per dare l'indice meschino, esiguo, della nostra ricchezza, quando il primo milionario è, appunto, il Comune, e, come tutti i milionari, è un po' folle, cioè lesina qualche centinaio di lire, in cose necessarie e profonde il suo denaro, o s'impegna a profonderlo, nelle spese superflue? Il Municipio nostro non è, forse, nè Morgan, nè Carnegie, nè Vanderbilt, nè Rockefeller; la sua fortuna è più modesta: i suoi milioni sono in minor numero: ma esso ci gioca, oramai, come un buon piccolo milionario che fuma delle sigarette da tre centesimi, ma che ha una scuderia da corse.

Ho innanzi agli occhi e io spero di potervelo comunicare, sempre che ne sia il caso, un elenco di progetti, di proposte, di cose mezze fatte o da farsi, ove la spesa, talvolta inutile, talvolta stravagante, quasi sempre imprudente, è fortissima. Io non sono il tutore del Comune, per grazia di Dio e neppure tu, amico lettore, per tua fortuna: ma qualche soldo, di questi milioni, è tuo ed è mio. Interessiamoci a questi pochi centesimi, tuoi, miei, lettore, perchè essi sono una parte di questi milioni.

$$
*
$$

Il Rione della Bellezza! Eccone uno, eccolo qua. Il suo nome è eminentemente pretenzioso: quando saprai bene che è, questo rione, amico lettore e fratello mio, lo troverai anche eminentemente ridicolo. Si tratta di quel grande deserto di Santa Lucia nuova, ove tutti gli innamorati del vecchio Napoli, preferivano, forse, vedere quel bel mare di Santa Lucia, l'antico, il nostro mare: diamogli un sospiro di rimpianto, in nome del pittoresco, consoliamo gli stranieri nella loro delusione e rinneghiamo la civiltà, tacitamente, nel nostro spirito. Quando non era stato inventato il rione della Bellezza, questo deserto malinconico, atrocemente triste, in certe ore del giorno, fiancheggiato da quella via polverosa e ineguale, doveva esser popolato così, dalla Cassa di sovvenzioni genovese: cioè dovevano sorgervi tredici grandissimi palazzi, tredici caserme enormi, simili alle due già costruite, quella ove si trova l'Hôtel Santa Lucia e la seconda che è in costruzione. Nulla di più brutto, di più goffo, di più pesante: strette, le vie, fra ogni edificio: e completamente perduta, dietro, la via di salita Lucia vecchia. Quando queste 
caserme orribili fossero sorte, un'altra pruova della mancanza di educazione estetica, sarebbe venuta ad affliggere il nostro spirito inquìeto: e le abbominazioni rettilinee, di cui parla Edgar Poe, avrebbero schiacciato, col loro orrendo aspetto, la nostra fantasia, amante della beltà, della grazia, della leggerezza. Ma vi è un Dio, in cielo! Dato il forte prezzo a cui la Cassa di Sovvenzioni aveva messo e tiene ancora quei suoli da cinque anni, dato che per costruire, là, dove vi è il mare, sotto, ci vuole un prezzo doppio e triplo di costruzione, nessuno volle comperare quei terreni, nessuno pensò di erigervi un palazzo o una palazzina e la società molto meno osò di costruirvi niente. Certo, la società vi ha perduto e vi perde molti denari: ma questo non ci riguarda. Noi rimpiangiamo Santa Lucia vecchia, gli stabilimenti di bagni, l'acqua sulfurea, le venditrici di acqua, gli ostricari, le trattorie e i tessitori di nasse! Noi li rimpiangeremo anche di più insieme, amico lettore, se mai il rione della Bellezza vi si debba compiere. Il nuovo progetto dunque in cui pare, quasi, che abbiano concorso Raffaello da Urbino, Michelangelo Buonarroti, Vanvitelli e Dante Gabriele Rossetti, è questo: invece di tredici caserme, esse saranno undici e saranno divise da vie più larghette, con file di alberi lungo le vie, simili a quelli da cui è contristato il Rettifilo e che, certamente, verso il mare, saranno distrutti dalle brezze marine, come si dice, sieno stati distrutti quelli della Villa. Questi undici edificî avranno, anche, attorno, un poco di verdura, una piccola fascia, verso il mare. E basta. Ma questa è dunque, la peregrina idea per cui il rione Santa Lucia, sarà chiamato il rione della Bellezza? E il progettista, diciamo cosi, sarà paragonato a Arnolfo di Lapo o a Lenôtre, architetto di Versailles? Nossignore.

Nel centro del nuovo rione, verso il mare, gli edifici si divideranno in semicerchio e lasceranno uno spazio, in mezzo, di ottomila metri quadrati - non t'illudere, amico lettore, ottomila metri quadrati non sono gran che - ove vi sarà un giardino, e, in mezzo, pare impossibile, una fontana. Attorno, attorno al semicerchio sorgerà un porticato, di stile greco-romano, dove sarà fabbricato solo un primo piano, ad uso di caffè, di birrarie, di cafè chantant, forse, sempre in istile greco. E basta. Questo è il rione della Bellezza: non oltre: non altro. Un giardinetto, cioè, poco più grande di quelli di piazza Cavour, diletto ritrovo di pezzenti di San Gennaro, di cabalisti, di piccoli pensionati del governo: un giardinetto che sarà due o tre volte grande come quello di piazza Municipio, ritrovo, questi, di persone che è inutile quì menzionare, sotto i paterni occhi chiusi dei consiglieri comunali, un giardinetto, con una fontana, dove, probabilmente, vi sarà uno zampillo, basso nei giorni di lavoro e alto nei giorni di festa: e, infine, questo porticato, per rammentare nella vita moderna, l'origine di Partenope, per rifare un poco 
Pompei, dice il progettista. Anzi, egli voleva far tutta una passeggiata pompeiana, lì, ma questa idea parve tanto barocca, tanto sciocca, che se ne accorsero tutte le anime buone e distratte degli assessori e protestarono. Non vi sarà la passeggiata pompeiana ma un pezzetto di Pompei, col porticato, l'avremo. Chi si metterà sotto questi portici: s'ignora: neppure è certissimo che vi si costruisca il primo piano. Il rione della Bellezza, or dunque, si riassume in un giardino, con fontana e con un portico. Il suo nome, allora, non ti sembra un poco esagerato, amico lettore? Non ti pare che la parola bellezza abbia un senso diverso e profondo? E che applicarlo a sì esigua e ambigua cosa, sia una grande audacia? E che il progetto e il progettista debbano soccombere sotto il ridicolo di quest'audacia?

$$
\text { * }
$$

Per aver questo giardino, con la fontanella e il porticato, ecco che cosa deve spendere il Municipio di Napoli. Anzitutto deve dare alla Cassa sovvenzioni di Genova la egregia somma di settecentomila lire: è vero che si pagano in trent'anni, queste settecentomila lire, ma un debito è un debito, anche se si paghi a piccole rate. Non vorrei affermare che il Comune debba corrispondere anche l'interesse, perchè non lo so: ma è probabile che per avere la fontanella nel giardinetto e il porticato, intorno, per aver ciò a credito, qualche interesse si dovrà pagare. Inoltre, il Comune concede alla società, di costruire un sesto piano a tutti gli undici edifici: calcolato, così, a occhio e croce, un piano di più, sovra undici immensi palazzi, può rendere alla società da novanta a centomila lire di maggior reddito, cioè un regaluccio di oltre due milioni di capitale, sempre per aver quel che sapete. Quanto saranno più belli, più accoglienti, più estetici questi palazzi di sei piani, invece che di cinque, lo sa il Signore!

Vi è dell'altro: la società ha il diritto di non lastricare più con pietre le vie fra $\mathrm{i}$ suoi palazzoni, poichè questo lastricamento costa molto: allo scopo di facilitarle ancora più la posizione, il Comune le permette di adoperare il macadam, col risultato di aver del fango in inverno, fango che macchia i vestiti e li rode; e la polvere più acre, in estate. Non basta ancora: la società ha la concessione della sorgente di acqua solfurea: non sarà gran che; ma è qualche altra cosa. Non vi pare che, per un giardino, una fontana e un porticato ciò costi molto, troppo, immensamente? E con tanti denari, tante concessioni, tante facilitazioni, il risultato sarà questo: e il rione presunto della Bellezza, sarà mortalmente brutto, se si arriva a compiere col suo anacronisma di Pompei, fra edifici di sei piani come in America; che il prezzo dei suoli, restando sempre forte e le 
difficoltà di costruzione essendo sempre grandi, la Cassa Sovvenzioni, seguiterà a non vendere e seguiterà a non costruire e che alla fine del salmo il rione della Bellezza consisterà in un piccolo giardino, in una fontana e in un porticato vuoto, fra un vasto deserto arido e polveroso. La società si sarà rifatta in parte dei suoi guai, con quelle settecentomila lire; il Comune dovrà pagarle e passando per Santa Lucia nuova, il cittadino inconscio creperà dal ridere, a veder quella buffonata, e tu amico lettore e io, cronista scettico e pessimista, tu ed io che non siamo inconsci, rimpiangeremo quei venticinque o cinquanta centesimi, parte tua e parte mia delle settecentomila lire!

\section{LA GRAN VIA}

Chi ha mai osato, chi oserà mai detronizzare via Toledo dalla sua sovranità cittadina? Chi toccherà mai alla sua corona di gloria e di vita? Chi potrà mai eguagliare, non vincere il suo fascino? Chi mai menomerà la sua forza e il suo carattere? Niente: nessuno. Non il tempo che tutto modifica e tutto trasforma: non gli uomini folli che delirano di mutare le cose, secondo il loro pensiero e il loro capriccio: non i costumi che si cangiano bizzarramente, pur riapparendo sotto novelle forme: non i fatti che sono regolati dalle misteriose correnti del destino. In questa profonda e palpitante arteria, corre un sangue la cui ricchezza è magnifica: il suo battito può diventare tumultuoso nella febbre dei grandi giorni, non può rallentarsi mai: le sue pulsazioni possono raggiungere il culmine della gioja, mai il minimo della fiacchezza: e mentre tutto l'immenso corpo della città dorme, sotto l'arco stellato del cielo, sotto il lume freddo e molle della luna, dalle sue colline fiorite nella notte fino al mare immobile, la profonda arteria vive e spande il suo metro di vita, nell'ombra tenue, fra le case alte.

Via Toledo non ha rivali, anche nelle vie più magicamente belle di Napoli: non nel mirabile sinuoso nastro che cinge graziosamente l'alto della città e che è il Corso Vittorio Emanuele: non nell'aristocratica e oramai deserta, e sempre nobile, sempre squisita Riviera di Chiaia: non nella indescrivibile via Caracciolo, sogno di pittori e di poeti: non nella possente via del Rettifilo, ove la modernissima città si sviluppa: nessuna di queste è sua rivale, poichè queste vie possono avere la bellezza, la forza, la grazia, la poesia, la tradizione, e hanno tutto questo e altre cose hanno, ancora, nella loro storia e nella loro espressione, ma Toledo ha tutto ciò e ha un'altra cosa, l'altra cosa grande, imponente, fremente, multiforme, multaninime, essa ha la vita, essa è vita.

Siate lontani, in paesi estranei: se il vostro animo s'immergerà nella triste nostalgia, è al suo ricordo che il vostro segreto rimpianto sarà più amaro. Siate quì e la vostra esistenza si svolga, per forza di cose, in regione cittadina lontana: la vostra vita vi 
sembrerà scialba e gelida. Uscite un giorno e non toccate questa via: la vostra giornata vi sembrerà vuota. Siate infelice, annojato, stanco, sperduto, sfiduciato di voi e di tutti: toccate le sue sacre pietre e come un sorso d'inebriante vino esalterà le vostre forze e si dilegueranno tutti i fantasmi angosciosi e per un istante, per un'ora, per un giorno, l'esistenza vi sembrerà, di nuovo, facile e lieve!

$$
*
$$

Via Toledo è la vita istessa, poichè nei secoli centinaja e centinaja di patrizî, di ricchi, spesero le loro fortune per adornarla di maestosi palazzi e vissero in questi palazzi, e vi tennero signoria, e vi lasciarono quella impronta larga e nobile di magnificenza che non si cancella: è la vita istessa perchè nella felice mescolanza delle classi che è una delle buone e oneste cose nostre, accanto alle grandi famiglie, migliaja e migliaja di famiglie vi sono vissute, nei secoli, e nei tempi più vicini, e adesso, e vi vivranno ancora, in una tradizione borghese che ha la sua potenza, in una tradizione popolare che ha la sua forza: è la vita istessa, perchè la fede vi eresse i suoi santuari, in cui migliaja e migliaja di anime sono venute, vengono e verranno, per sentieri noti, innanzi alle immagini note e care, anime pietose, anime fedeli, obbedienti ad un'antica e pur dolce consuetudine: è la vita istessa, perchè il commercio e la industria da secoli, vi mise i suoi emporî, in una tradizione di lavori, di attività, di onestà e di fortuna che, ora, è giunta al massimo del suo splendore. Abitare a Toledo, vivere a Toledo, aver bottega a Toledo, fu, è, come una eredità degli avi, come il rispetto ad un costume sacro, come la rinnovazione di un patto con i lontani antenati, come una fede giurata, come una necessità familiare e pubblica.

O cuore dei cuori: Via Toledo! Il torrente dell'umanità, da secoli, in ogni giorno e in ogni minuto si è svolto, ora mite, ora forte, ora fragoroso, ora clamante, sul tuo selciato e sui tuoi marciapiedi: e ogni uomo, ogni donna che vi è passato, dolente, ridente, fremente, pieno di vita o pieno di morte, vi ha lasciato una traccia viva e ogni dramma, ogni tragedia, ogni commedia che vi si è svolta, vi ha messo il riflesso di un suo ricordo: e ogni grande o piccolo fantasma della storia che vi è apparso, vi ha messo l'ombra della sua grandezza o della sua piccolezza: e i nostri e noi vi abbiamo lasciato in tanti periodi della nostra esistenza, vi abbiamo lasciato il meglio di noi, un pensiero, un sentimento, un sorriso, una lagrima. Ah se Toledo è la vita istessa, è perchè ognuno le fece questo dono bello e fatale: è perchè glielo diedero i sovrani e il popolo, in tutti i tempi: è perchè glielo diedero i dittatori e la plebe: è perchè glielo diedero i poeti e gli 
amanti: è perchè tutti gli diedero vita, gli scienziati, i filosofi, gli uomini di Stato, i capi delle fazioni, i capi della folla: tutti, tutti, le donne, gli uomini, i bimbi, i vecchi, i malati, persino i morti di cui le solenni esequie lasciarono la memoria di un nome e di una pompa lugubre. Ah è la vita istessa, Toledo e tutti così l'adorano, fervida di ogni forma alta o bassa, elegante o triviale, ricca o povera, florida o meschina: e tutti la onorano, e tutti l'hanno onorata e non un sovrano, non un imperatore, non un grande che, quì giunto, non ne sentisse il primo palpito largo e forte, nei clamori della gente, salienti clamori sino al cielo sereno!

$$
\text { * }
$$

Questo ho io ripensato, con meraviglia, quando ho notato che, per la prima volta, un ospite sovrano giungerà fra noi e penetrerà nella Casa del Re, in corteo nobilissimo, senza esser passato per via Toledo: e questo sentono e se ne rattristano, profondamente, le migliaja di buoni cittadini di via Toledo, delusi nelle loro legittime speranze e centinaja di commercianti e d'industriali che, da tale avvenimento bello e popolare, attendevano non solo pascolo agli occhi, ma onesto vantaggio al loro lavoro. Alte ragioni che noi ignoriamo fecero scegliere un itinerario bello, ma molto più breve: e tagliarono fuori, con involontaria crudeltà, certo, la vita istessa napoletana, l'antichissima e fedele via di Toledo, quella che cosi lealmente: ed entusiasticamente festeggiò i suoi re ed i suoi ospiti, quella che pure, seppe adornarsi di drappi e di ghirlande e fece piover fiori sulle regine e sulle principesse. Alte ragioni! Noi non le conosciamo: e debbono, certo, esser molto forti e molto rispettabili: nè l'itinerario, oramai, può mutarsi. Sia! Ma come a Parigi, subito dopo che i Sovrani d'Italia ebbero attraversata l'Avenue des Champs Elysées e la inobliabile piazza della Concordia, per recarsi al palazzo degli Affari Esteri, senza toccare il centro di Parigi viva, il cuore di Parigi, la piazza dell'Opera, si trovò modo di farli escire, novellamente, e di far loro attraversare l'Avenue de l'Opèra, si trovi, anche quì, modo di far traversare, ufficialmente, a ora stabilita, il Presidente della Repubblica, per via Toledo, per tutta la via Toledo, tutta quanta: e questa cosa si promulghi: e si contentino, così le giuste aspettative di una strada ove tutto di Napoli si concentra e si esprime: e si dia agli occhi curiosi e dolci di Emile Loubet che viene da una delle più belle città del mondo questo spettacolo inarrivabile. Se il Presidente della Repubblica va via, di quì, senza aver visto la via Toledo, in un pomeriggio di primavera, gremita di gente, addobbata, 
imbandierata, infiorata, e fluttuante e ondeggiante e tumultuante di folla, è come se non avesse visto Napoli.

\section{GUERRA AI LADRI}

Un cattivo odore di stantio, di cose antiche e consunte, tenute troppo tempo chiuse e tirate fuori, si è diffuso nell'aria che respiriamo, da qualche giorno. Nei primi comizî, nei primi proclami, con una certa finzione di serietà, anche, son venuti fuori dagli armadi sgangherati della rettorica amministrativa: il partito clerico-borbonico, il partito clerico-moderato, il partito socialistoide, il partito anarcoide e, persino, guarda, guarda, quella consumatissima cosa che è il partito liberale. È come un mucchio di ferri vecchi polverosi e arruginiti, tirato fuori da un camerino di sbarazzo: come un fagottello di cenci sdruciti e sporchi, disciolto, in terra. La polvere acre si distacca da tutto questo tritume: la muffa si attacca, viscida, alle mani di chi vi si accosta: e il libero aere ne è ammorbato. La gente passa, si tura il naso, alza le spalle e sorride di scherno. Per molti anni, queste parole, queste frasi, ebbero un contenuto di vita: ma il tempo è trascorso e $\mathrm{i}$ tempi si sono mutati: ma tutto questo è vuoto, è floscio, è senza colore, è senza sangue, è simile al palloncino di pelle che era leggiero, volava in aria, aveva i bei colori della gioja, che il bimbo ha rotto e che è, adesso, uno straccetto ignobile. Nulla di questo esiste, più: nulla di questo risponde alla rinovellata coscienza moderna: nessuna di queste formole, ha più espressione e nessuna ha più influenza. Guardate, nella vita vera, piuttosto! Osservate, nella vita vera, tutte le profonde trasformazioni che stupiscono. Vi sono dei cattolici che sono italianissimi: vi sono degli anticlericali che sono credenti, vi sono dei clericali che sono democratici: vi sono dei democratici che sono imperialisti: vi sono dei liberali che restaurerebbero la pena di morte: vi sono dei repubblicani autoritarii e assolutisti: vi sono dei socialisti che adorano il Re: vi sono dei radicali perfettamente monarchici: vi sono dei monarchici che dicono un male orrendo della monarchia: i framassoni che detestano il clero, credono all'Architetto dell'Universo: e i borbonici, infine, poichè anche di questo si parla, i borbonici si riassumono in quell'incantevole uomo d'età - egli invecchierà, più tardi - che è il duca di Regina, caro a tutti, riverito da tutti i partiti, sottopartiti, frazioni e sottofrazioni. Il travolgimento tumultuario delle idee, il turbine sempre più precipitato delle opinioni, tutto questo enorme cataclisma morale, donde escirà, domani, e già essa sorge splendente come l'aurora, la coscienza nova, ha già così capovolto ogni ordine di criteri e di concetti che, veramente, coloro che, ancora, si attaccano al funesto ciarpame del passato, coloro che 
tentano di brandire delle armi infrante e senza taglio, che tentano di agitare una bandiera stinta e a brandelli, destano un sorriso di ironia e di pietà!

Ma in tanta bizzarra confusione, il paese nostro, questa Napoli nostra, cerca una guida nei fatti, cerca la verità nel buon senso. Dice Napoli, quietamente: ecco, io ho bisogno di risorgere. Io non solo debbo vivere, ma debbo svolgere tutte le mie forze sociali e individuali: ognuno dei miei cittadini, sia pure il più oscuro, il più ignoto deve aver lavoro, salute, protezione, educazione, e tutti i cittadini e, io, Napoli, debbo prendere il mio posto bello, nobile, forte, nella vita operosa ed efficace moderna. Non solo io voglio risorgere; ma, tutti gl'italiani che hanno cuore, vogliono la mia risurrezione: ma tutti i miei fratelli del nord mi stendono la mano affettuosa e salda, perchè io risorga: ma gli uomini del parlamento, ma gli uomini dello Stato, ma il Sovrano vogliono ardentemente la mia resurrezione. Essa, però, si deve compiere con tutte le forme più larghe, più potenti, più limpide e più pure. Perchè io risorga debbono fra me giungere i capitali stranieri e i capitali nordici e siano benedetti, purchè essi non trovino alle mie porte e fra le mie mura, chi metta loro la taglia, se vogliono entrare. Perchè io risorga debbono formarsi, quì, delle vaste imprese industriali, ove chi è lavoratore, trovi mercede onesta e aiuto sociale, ove chi è possidente trovi onesto guadagno, ove chi è capitalista, possa collocare onestamente e securamente il suo danaro, ove tutte le intelligenze belle e vivide napoletane possano trovar campo di azione, ove tutta questa forza simpaticissima d'ingegno, possa manifestarsi in opera utile, efficace: ma queste imprese industriali debbono esser fatte alla luce del sole, senza transazioni equivoche, senza concessioni losche, senza premî, senza provvigioni; e come si è fatto altrove, a Milano, a Genova, a Torino, ove centinaja di tali imprese nacquero, vivono e prosperano, senza che sia stato loro necessario di corromper nessuno, anche da me, quì, nella mia nuova atmosfera morale, questa, cosa bella l'affare onesto, l'affare semplice, l'affare in cui non vi sono guadagni illeciti o strabocchevoli, da nessuna parte, ma in cui tutti possano prosperare, l'affare deve sorgere, svilupparsi, dilatarsi, portar bene ed esser parte integrante della mia risurrezione. Perchè io risorga, completamente, debbono le banche che già sono, quì, aiutare il mio popolo, aiutare le oneste industrie, aiutare le oneste iniziative e sottrarre il popolo e gli industriali e tutti quelli che han bisogno del credito, all'usura: e altre banche si debbono fondare, ancora, con denari venuti di fuori, con denari di quì, e tutte, le nuove, le vecchie, non debbono pesare sui deboli e sui miseri, non debbono servire a scopi non bene definiti, ma avere, sì, sì, anche le banche, un criterio morale di assistenza alla popolazione mia. 
Io invoco il lavoro, invoco le società, invoco le industrie, invoco le banche, che dovranno redimere la mia miseria, il mio ozio e la mia inciviltà: ma tutto questo deve esser fatto in un'altra maniera, non più in quella di prima, in una maniera schietta, leale, franca, in una forma delle più integre, con, una probità perfetta, con quel rigore di coscienza, da tutte le parti, che, in tanto rivolgimento di cose, è la via della verità e della vita.

E, a proposito delle non imminenti ma prossime elezioni amministrative sapete che dice, Napoli? Napoli dice questo: A me importa poco che vadano al Consiglio Comunale dei clericali, dei borbonici, dei moderati, dei liberali, dei democratici, dei socialisti, o degli anarchici: tutto ciò mi è indifferente. Io voglio degli uomini onesti: io voglio delle coscienze secure: io voglio delle anime austere. Le loro opinioni politiche non mi riguardano: solo i loro sentimenti morali m'interessano. Non voglio ladri, io, al Comune; e per ladri non intendo solo quelli che si mettono in tasca il denaro mio, il mio povero e scarso denaro, ma tutti quelli che aiutano i ladri miei o che permettono, chiudendo gli occhi, che mi si rubi. Non voglio, al Comune, nè affaristi, nè compari di affaristi, nè rappresentanti di affaristi, nè amici degli amici degli affaristi. Vi sono, fra i liberali degli onestissimi uomini? Io lo vedrò: io avrò fede in loro, quando avrò veduto e saputo: e io manderò al Comune questi liberali onestissimi. I clericali non amano Roma capitale, non vogliono festeggiare il venti settembre, s'irritano di dover riverire il Re: ma sono onesti? Io voterò per essi, poichè la loro probità mi affida: e, più tardi, penseranno essi a non urtare i miei sentimenti d'italianità. I socialisti sono violenti, sono intemperanti, spesso utopisti: ma sono onesti e vogliono il trionfo della onestà, lo vogliono con tutte le loro forze, come io lo voglio? Io voterò per essi, come un sol uomo. Io voterò per chiunque mi risulti, in faccia al sole che egli sia un galantuomo. Un galantuomo può sbagliare, ma non può tradirmi, un galantuomo può errare, ma non può vendermi. Di fronte al mondo che conobbe le mie lunghe sciagure, di fronte all'Europa che si stupì di me, come di un covo di malfattori, di fronte all'Italia, che mi guardò dolorosamente sorpresa, io debbo, ancora una volta e, adesso, più che mai, dimostrare che le mie sciagure mi venivano da ben pochi infami miei figliuoli, che il covo non era che una piccola tana di sporchi rosicanti, che io ho migliaja e migliaja di cittadini onesti e buoni e che, fra queste migliaja, io posso, io voglio scegliere ancora una volta, gli onesti che mi debbono amministrare. Qualunque sia la veste di cui si copra l'uomo dalla coscienza infida, io lo riconoscerò: qualunque sia la maschera che copra il suo viso, io 
ne discioglierò i nodi: in qualunque modo mi si tenti di ingannare, non vi si giungerà più.

Troppo ho sofferto nell'onore e nella prosperità: troppo ho lagrimato di vergogna e di indignazione. Io debbo cominciare per salvarmi, se voglio esser salvata da tutto, da tutti. Nelle mie mani è la mia prima risurrezione: cioè quella della mia esistenza, morale, cioè quella del mio decoro sociale. Farò, io, veder al mondo, all'Europa, all'Italia che di tutti i doni della sorte, io sono degna, che di tutti gli aiuti fraterni, io sono degna, io, Napoli, paese di gente onesta, mandando al Comune solo gli onesti, chiedendo ad essi, che da essi si prosegua e si esalti la mia riabilitazione!

\section{CRISTO DICE...}

Più giusto e più opportuno, forse, è l'ignorare, il voler ignorare, noi, in questo singolare, intenso e possente dissidio di Torre Annunziata, che sia il trust degli industriali, perchè e come sia sorto, su quali patti sia stato basato e a quale ente finanziario o a quale persona vadano, divise o riuniti, i molti benefici del trust e anche i suoi molti svantaggi. Probabilmente, certo, anzi, gli industriali di Torre Annunziata non sono degli odiosi e crudeli capitalisti presi uno per uno: anche essi, forse, vengono dal popolo laborioso e debbono alla fatica e alla sorte bella dei loro genitori, debbono alle loro fatiche e alla loro bella sorte, se la fortuna li mise alla testa di una ricchezza e se così è, non può il loro memore cuore aver obbliato donde i loro padri partirono, donde partirono essi, nella loro gioventù e questa memoria incancellabile deve aver temperato, tempera, a ogni modo, la superbia e la durezza di chi si trova dalla parte del denaro e del potere. È anche certo che in questi ultimi due mesi di lotta veramente eroica, gli industriali hanno sopportato e sopportano gravi perdite di denaro, le cui conseguenze non si possono notar subito, poichè ognuno di loro aveva la sua riserva e di vari la fortuna è molto forte: è anche certo che mille energie si sono disperse, mille occasioni si sono perdute, e che questi danni sono profondi, così profondi che molto tempo, molta forza, molto lavoro e molta pazienza sono necessarî a portarvi dei rimedî. Riveriamo la giustizia, in ogni nostra parola, se vogliamo che la folla ci creda giusti e probi; e non colpiamo della gente che è al sommo della fortuna sociale, con la scusa che essa è ricca e che ciò offende il povero. Per quanto la fortuna tenda sempre più, dapertutto, a livellare la ricchezza, a imporle, sovra tutto, tali leggi, tali doveri, tali obblighi, da venirla lentamente diminuendo, quasi togliendole ogni possanza e ogni larghezza, quasi mettendole innanzi, constantemente il fantasma dei meno felici, dei più oscuri, e inducendola a guardare e a temere questo fantasma, come cosa viva, dei ricchi 
esisteranno sempre, nel mondo, e il vivo ingegno, la salda volontà, la tenacia ferrea, il cumolo delle circostanze che noi chiamiamo Fortuna, avranno sempre i doni della terra e del cielo; ed è ingiusto punire costoro, semplicemente perchè vi sono esseri senza mentalità, senza volontà, miseri di anima e di corpo, destinati a una vita umile, da cui nessuna legge, nessuno Stato e nessun uomo può trarli. La ricchezza ha molti giusti persecutori, quando essa è tirannica, aspra, orgogliosa e senza pietà: essa ne ha anche, perchè è la ricchezza solamente; lasciamola che si difenda come può, se può, se sa, se vuole, se le riesce!

$$
\text { * }
$$

Ma diamo tutto il nostro cuore fraterno, pieno di un sentimento traboccante di bene a questi cinquemila operai, che, da circa settanta giorni resistono a ogni tristezza fisica e morale e da Torre Annunziata danno un esempio di fermezza, di costanza, di sacrifizio veramente ammirabile. Che gli occhi di tutti i lavoratori del mondo si fissino sulla bella cittadina che si specchia nel mare, e che un senso di rispetto grande nasca per questi operai che servono, con ogni privazione, non solo la loro causa, ma la causa di tutti quelli che lavorano. Più di due mesi di sciopero essi stanno subendo, pazienti vigili, inaccessibili: e le loro sofferenze materiali son ben grandi. Man mano, i denari per sostenere lo sciopero sono finiti ed essi si sono contentati di veder sempre più scarsi i soccorsi della loro lega, si sono contentati di pochi soldi. Ogni tanto, qualche generoso sussidio arriva, ma essi sono molti, i bisogni sono grandi e dopo qualche giorno la ristrettezza, la miseria, sì, diciamolo la miseria diventa più pesante, più lugubre più nera. Sapete che mangiano molti di essi? Patate! I contadini, i massari nelle campagne con animo misericordioso, permettono che le famiglie degli operai vadano a raccoglierle senza molestarli; e ogni mattina con i sacchi sulle spalle, i ragazzi degli operai vanno fuori, nei campi, negli orti, nelle masserie, a raccoglier queste patate: ciò non costa nulla ed è un cibo, almeno, un cibo caldo, cotto nell'acqua con cui si sfamano uomini, donne, bimbi e vecchi. Cento episodi pietosi, commoventi, si potrebbero narrare, di costoro, e in qual modo essi si sostengano scambievolmente: e come i più forti dieno forza ai più deboli: e come le donne sieno più ardenti e più ferme: e come non uno fallisca, non uno tradisca, non uno osi tradire. Cinquemila, sono, ma la volontà è una sola. Come una barra di ferro che nulla fa deviare, che nulla smuove, che nulla rompe: e intanto, spesso, le loro viscere sono corrose dalla fame: spesso, non possono dare nulla ai loro figliuoli: a poco a poco tutto quello che avevano in casa, è partito, impegnato o venduto: i loro 
amici, i loro compagni, i loro confratelli, li hanno aiutati, come hanno potuto, ma anche questi aiuti sono limitati, non possono consolare, sollevare una massa così enorme. Cinquemila, sono e sembrano un solo uomo a cui la volontà invincibile faccia compiere un miracolo quotidiano, da settanta giorni, quello di subire ogni privazione e di non lagnarsi e di non cedere di una linea e di credere, sì, di credere nella propria vittoria, poichè è la fede nell'ideale quella che finisce, sempre, per rifulgere! Cinquemila, sono, e si sono votati, come un uomo solo, al benessere della loro collettività al loro migliore avvenire, e in questo voto sociale che hanno fatto, danno, come antichi eroi, il migliore del loro sangue e il migliore delle loro forze. Cinquemila, sono, e, oramai, con l'alto loro coraggio, vinti tutti gli ostacoli, il sacrificio di tutti continua, sempre e non finirà senza trionfo, perchè, centosei di essi non restino nella strada, senza lavoro, senza pane!

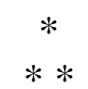

Il monte della Quarantena, in Palestina, sorge fra le floride pianure ove ride e corre il limpido fiume Giordano e la gran pianura deserta ove fumica il plumbeo Mare Morto, che seppellì, nelle sue acque torbide e acri Sodoma e Gomorra. Questa montagna, non alta, è rocciosa, asprissima: non vi nasce pianta, non vi nasce fiore. $\mathrm{E}$ Cristo vi passò quaranta giorni in preghiera, in solitudine, in penitenza, dopo che il Precursore, lo ebbe battezzato nelle acque del Giordano. Solo, era, sulla montagna: e il Maligno lo tentava. Cristo era disfatto dalle orazioni e dal digiuno. Diceva, il Maligno: Tu muori di fame; se sei figliuolo di Dio, fa un miracolo e cangia in pane queste pietre. Cristo taceva. Fa, fa, un miracolo, ripeteva il Maligno, e cangia in pane le pietre! e Cristo, allora, guardandolo, gli disse: l'uomo non vive solo di pane. Ah che parola voi diceste, Signore, da questa montagna e come essa è una delle più grandi, delle più alte, delle più pure, delle più fiammeggianti, in tutti i tempi, in tutte le coscienze! Duemila anni fa voi l'avete pronunziata, in un'ora sacra alla elevazione dell'anima, combattendo col Tentatore che vi offriva tutti i beni materiali della terra, sovra una montagna arida e nuda, in una solitudine senza eco, in un momento supremo: e la parola vibra nel mondo degli spiriti, come un conforto e una esaltazione. È per i poveri, per i deboli, per gli infelici, per i sofferenti, che questa parola è stata detta: è contro i ricchi, i potenti, i superbi, i malvagi, che essa è stata pronunciata: è per la guerra che sempre è stata, che mai finirà, fra i miseri e gli epuloni, che questo è stato proclamato. Che importa la povertà, se l'uomo non vive di solo pane, ma di un contenuto spirituale che rende la sua anima lucida e formidabile, e vince le sue caducità fisiche? Che importa, la sofferenza, 
se non il pane solo è pascolo dell'uomo, ma un conforto interiore che lo rende più forte di ogni tristezza? Che importano la privazione, lo stento, il duro sacrificio, quando per vincere queste torture, non il pane è necessario, ma un'energia morale che arriva sino all'eroismo? A migliaja, a migliaja, questi ignoti soldati dell'anima sono caduti nel mondo, decimati dalla fame, dal freddo, dalle infermità, ma essi passarono la loro idea, la loro fiamma, la loro speranza ad altri combattenti: ma questa battaglia contro tutte le tentazioni basse e ignobili, questa battaglia nel nome dello spirito trionfante sulla carne, ha già avuto mille clamorose vittorie. $\mathrm{O}$ minatori che soffocate nelle viscere della terra, o faticatori dei campi che vi curvate sulla vanga, o operai che vi accasciate di pesante lavoro, nelle officine, la parola del monte della Quarantena è il balsamo che vi guarisce, vi vivifica, vi esalta: siate o non siate cristiani. Colui che era povero e che amava solo $\mathrm{i}$ poveri, che era oscuro e che perseguitava i potenti, che era umile e che disprezzava l'orgoglio, Colui che doveva vivere e morire, per tutti gli sventurati, disse a Satana, signore delle ricchezze tutte umane: L'uomo non vive di solo pane. Ogni volta che una creatura della terra preferisce la fame all'obbrobrio, preferisce il freddo alla vergogna, preferisce la morte alla viltà, ogni volta che una creatura umana in lotta con la fortuna altrui, con la potenza altrui, con la tirannia altrui, non cede, non transige, non si piega, e talvolta vince e talvolta muore, ma muore vincendo, il grande motto ha compiuto il suo miracolo spirituale.

\section{IL PANE DELL'ANIMA}

Quando il direttore del MATTINO si trova, per caso, in polemica col giornale ROMA lo chiama, per lo più, il giornale dei portinai. Ciò mi ha sempre fatto sorridere.

Il ROMA potrebbe essere il giornale dei portinai, come è quello dei bottegai che rientrano a pranzo, fra l'una e le due pomeridiane, ma non è. I portinai napoletani non sanno leggere. Facendo una inchiesta curiosa e bizzarra, voi potreste trovare, sovra un centinaio di guardaportoni da quattro a cinque che sanno leggere, non di più; e per disimpegnare gli obblighi del proprio mestiere, svariati e non senza difficoltà, i portinai napoletani adoperano la sveltezza naturale del loro ingegno, fanno le ambasciate, distribuiscono le carte da visita, dividono le lettere e i giornali, ma non sanno leggere. Passando ai cocchieri, gente sveltissima se mai ve ne fu, domandate ad uno di essi, per esempio, di portarvi a via Partenope, numero diciotto: anzi tutto, egli vi chiederà se si tratta del teatro Partenope: e, in secondo, quando sarete giunti, con la sua carrozza, a via Partenope, egli non saprà punto trovare il numero diciotto: il cocchiere napoletano raramente sa leggere e ignora quasi sempre la figura grafica dei numeri, anche accanito 
giuocatore di lotto, come è. E, passando di classe in classe, non solo il forestiere si accorge e si sorprende e rimpiange che fra il popolo napoletano, così intelligente, così vivido, così rapido, sia innumerevole il contingente di coloro che non sanno leggere, ma voi stesso, voi, napoletano, ogni volta che vi trovate di fronte a un ignorante, a un analfabeta, voi sentite il rammarico acuto di tanta barbarie e di tanta oscurità; e, talvolta, vi assale il ribrezzo di tanto oblio e di tanto abbandono, in cui è lasciata questa povera gente. E, ogni tanto, in quelle tristi interviste con qualche spettro della notte, che la malinconia della deambulazione notturna vi procura, in quegli incontri singolari e tetri, con un ragazzo della malavita, con un cercatore di mozziconi, con un caffettiere ambulante, voi udite il motto profondo, aspro, crudele, in cui il popolo napoletano riassume il suo profondo rispetto per la cultura e il dolore della propria ignoranza, crudele motto che emana dall'intimo dell'anima, come un rinfaccio, come amarissimo rimprovero alle classi più alte. Voi v'interessate al guaglione di mala vita, al fantomatico mozzonaro, al singolare caffettiere che gira come un fantasma, esso, dall'alba, per le vie napoletane e compiangete la sua sorte ed egli si compiange, così, crollando le spalle, filosoficamente. Ma tu sai leggere?- voi gli chiedete. Egli vi guarda, risponde: Signò, si sapesse leggere nun starria cca: starria a Palazzo. Per il popolo napoletano, chi sa leggere non può esser cercatore di mozziconi, venditore di ulive, ladruncolo notturno, ma può diventare Re o qualche cosa di simile al re, abitare la Reggia e non un tugurio o gli scalini di una chiesa, comandare gli uomini e non finire in carcere o all'ospedale.

$$
\text { * }
$$

Centinaia, migliaia di bambini, di bimbe pullulano, si arrotolano, si aggrovigliano in tutte le vie, dalle più aristocratiche alle più popolari, creature seminude, scalze o malamente coperte o appena vestite: e non si sa donde vengano e dove vadano, non si sa a chi appartengano, come vivano, come muoiano. Eppure hanno madre e padre, queste misere bimbe questi bimbi miserelli e vorrebbero, questi genitori infelici, o privi di lavoro o provvisti di un lavoro mal remunerato, faticosissimo, durissimo, vorrebbero, questi genitori, mandare, in un asilo, in una scuola, queste creature delle loro visceri, vorrebbero che oltre il piccolo e rude pane del corpo, dato, ahi, con così rigorosa misura, fosse loro dato, da chi ne ha l'obbligo strettissimo, da chi ne ha il sacrosanto dovere, il pane dell'anima, l'istruzione. Desiderio insano! Mancherà, spesso a questa immensa folla di piccini e di piccine, di ragazze e di ragazzi, il modo 
come sfamarsi poichè, pare, la povertà napoletana sia molto pittoresca e i custodi dell'estetica adorano questa manifestazione possente e triste di dolore sociale: mancherà, senz'altro, il pane dell'anima, quello che dovrebbe dar frutto di bene intellettuale, di bene morale, mancherà senz'altro la istruzione. Vi è ancora fra il popolo, una istituzione strana e caratteristica: una specie di piccola scuola tenuta, da qualche donnetta, in un basso più spazioso degli altri: altre donnette, operaie, serve, lavandaie, stiratrici, vi portano i loro figliuoli e le loro figliuole, alla mattina, prima di andare al lavoro e pagano un soldo al giorno, le più facoltose, diciamo così, venti soldi, e quindici soldi al mese, le più sventurate. La donnetta che ha la scuoletta, non insegna nulla a tutte quelle creature: le tiene raccolte un poco, poi, le lascia scorazzare: le sgrida, sempre: urla, dietro loro: le sculaccia: pianti, strilli, singhiozzi: ma, infine, è responsabile, per un soldo al giorno, per tre centesimi, per due centesimi, di ogni bimba, di ogni bimbo, sino alla sera. E mi rammento, anche, la mia giovinezza, e un certo diploma di grado superiore che mi fu dato, per tre anni, mentre raggiungevo questo diploma, questa missione di dare il pane dell'anima alle figlie del popolo, continuamente rammentata, a ogni problema di aritmetica sbagliato: e infine toccato miracolosamente questo scopo del massimo diploma, l'obbligo del tirocinio di maestra, in una di queste scuole, ove accorrevano queste figlie del popolo, a cui io doveva insegnare a leggere e a scrivere.

E andai piena d'interesse, di gentile ansia segreta, di emozione, persino, a fare la tirocinante e mi trovai fra molte bimbe assai decentemente vestite, alcune con eleganza. Una per una le interrogai, queste figlie del popolo, chi fossero, donde venissero; e appresi, man mano, che eran figliuole di professionisti, d'impiegati, di negozianti, di bottegai, e fra settantadue scolare, una solamente, una, era una figlia del popolo, lacera, pallida, impertinentissima, intelligentissima, affascinante. Una! Più tardi, io sparvi dalla scuola, perchè avevo finito di fare la tirocinante: la piccola Buonfantino, indimenticabile al mio cuore tenerissimo, ne sparve, perchè morì, di tisi, a undici anni. Era una figlia del popolo, quella: ma la scuola non era fatta per essa.

$*$

$* *$

E non vi sono scuole, a Napoli! Non ve ne sono! Ogni tanto, noi ci riuniamo, diamo un ballo splendido, con una lotteria di oggetti d'arte, tutta la grande società napoletana e la meno grande v'interviene e la Croce Rossa prende trentamila lire: ma le scuole mancano e migliaia di ragazzi e ragazze s'imputridiscono il corpo e l'anima nelle 
vie fangose. Non vi sono scuole: mentre noi per un mese, organizziamo una Kermesse enorme, con sessanta dame nei chioschi, e gli ottanta o novanta ciechi di Caravaggio, che hanno già ereditato due o tre fortune, ricevono venticinquemila lire. Non vi sono scuole: e altre dame della Società Margherita e io con esse, organizzano, organizziamo, conferenze, recite, gite, per aiutare ventidue o ventisette ciechi a domicilio, comprando loro un pianoforte o un fonografo o una biccicletta! Non vi sono scuole, a Napoli, e le maestre muoiono di fame e le ragazze e i ragazzi del popolo vanno al vizio, alla corruttela, al disonore al crimine: e vi stupite delle statistiche dell'onta, del delitto, a Napoli, quando dimenticate che non vi sono scuole, che invano qualche anima buona di assessore grida, perchè se ne aprano delle altre, mentre il goffissimo progetto del quartiere della bruttezza, a Santa Lucia, chiede un milione e duecentomila lire, poichè ciò fa comodo a un assessore qualunque! Non vi sono scuole, a Napoli, e questi cattolici che sono al Municipio di Napoli, non si vergognano di far perdurare questa cosa infame, che è l'analfabetismo, di cui tutti arrossiamo, innanzi non agli stranieri, solamente, che ne ridono ironicamente, beffandoci, ma innanzi agli italiani di Lombardia e di Piemonte. Non so da quanti anni si sta delirando e spendendo intorno al Maschio Angioino, sempre e la cancrena più ributtante divora il popolo napoletano, confitto nelle tenebre dell'ignoranza: e neppure i cattolici che da Cristo Signore Nostro avrebbero dovuto apprendere l'amore dei piccoli e degli oscuri, fanno niente. I socialisti domandavano la refezione scolastica: e avevano ragione, ma prima della refezione che andrebbe a figliuoli delle persone agiate, aprire delle scuole, aprirne altre cento, dappertutto, ecco quella che è la carità sociale, la solidarietà sociale! Viceversa, noi ci occupiamo se il lampadaro di S. Carlo toglierà la visuale a coloro che vanno in quarta e quinta fila: questione gravissima. Costoro che si agitano per questa cosa bizantina, sono pregati d'informarsi un poco, così, per sapere, quanti degli abitanti ordinarii delle carceri di San Francesco, di Sant' Eframo e di Santa Maria ad Agnone sanno leggere. Dopo, si covrano la faccia con le mani: se hanno un poco di rossore!

\section{IL PADRE DEL POPOLO}

I miei occhi hanno visto l'imponente e toccante spettacolo; e il fremito che danno le cose grandi e sincere, ha sconvolto il mio spirito. Un popolo ha urlato di disperazione, ha gridato di collera, ha pianto di dolore, perchè Ettore Ciccotti non è più deputato di Vicaria: e per tre giorni e tre notti, questo furore di popolo, pieno di singulti e pieno di lacrime, si è espresso nelle forme antiche, puerili e semplici, della rivolta popolare: il sasso raccolto nelle vie suburbane e che fende l'aria, fischiando, il pezzo di 
legno greggio che non è neppure un bastone ma che difende ed offende, il vaso di fiori lanciato dalla finestretta del tugurio: e un desiderio folle, funebre, di morire, spingendosi avanti, contro le armi cariche e pronte a far fuoco, spingendosi avanti, le donne sotto i piedi dei cavalli dei soldati, così, ebbre di morte! Se più tragica, se infinitamente più tragica non fu l'avventura del popolo di Vicaria, si deve al medesimo Ettore Ciccotti che consigliò, a voce, per lettera, la calma, la pace, in nome del profondo vincolo fra lui e questo popolo di Vicaria: si deve alla sua partenza, alla sua assenza, atto di altruismo tenerissimo, con cui si sottrasse al terribile entusiasmo e ne placò, così, anche il disegno di rivoluzione e di morte: ancora una volta, egli salvò il quartiere Vicaria dal sangue e dalla strage. E l'ira folle, lentamente, si è sedata, poichè questi possenti impeti delle masse non possono e non debbono aver durata: ed è restato, dovunque serpeggiante, in cento episodii commoventi, il dolore di aver perduto Ettore Ciccotti, come deputato di Vicaria. Nei crocicchi, un organino si ferma e l'uomo dalla manovella, comincia a macinare una musica bizzarra: un altr'uomo canta: e la canzone parla di Ciccotti, il padre del popolo, e tutti si mettono a cantare, un coro, crescendo la folla: delle cartoline col ritratto di Ciccotti circolano, fra la gente: le donne le afferrano, le baciano, le conservano nel seno. Un venditore di giornali passa, è un vecchio: ha la testa fasciata: fu ferito, in una di quelle notti: e camminando a passo lento, con voce fioca, grida il giornale e aggiunge, come ritornello: ànn'acciso' u padre nostro Ciccotti. In un angolo di Porta Capuana, una donna parla, fra un gruppo di donne: è eccitata, ha le lacrime agli occhi, narrando non so quale benefizio che ella ebbe da Ciccotti; e le altre, a poco a poco, si mettono a gemere, intorno: e come se qualcuno fosse morto, esse esclamano: avimmo perdute nu patre, nu patre! Altrove, un uomo vestito bene, un signore, infine, ma noto nel quartiere, è circondato da altre donne, che gli raccontano le loro disgrazie, ed egli ascolta, pensoso, crollando il capo: e il ritornello, più malinconico, più triste, ricomincia, ancora: ce l'hanno levato, signò, ce l'hanno levato! Entrate, non nelle botteghe della borghesia di Vicaria, ma nei bassi di san Giovani a Carbonara, di via Santi Apostoli, delle traverse del Nuovo Corso Garibaldi, di Porta Capuana, e in ognuna di quelle tane ove manca l'aria e manca la luce e ove il popolo napoletano vive, per colpa dei suoi mali governanti, come se non fosse uomini e non fosse cristiani, e voi troverete il ritratto di Ettore Ciccotti, accanto a quello della Madonna. Nominate a uno di quei popolani, a una di quelle donne, quest'uomo: e vedrete il volto loro infiammarsi ed esaltarsi, poichè voi avrete loro nominato il padre, 
non quello che dette loro la natura, ma il padre della loro miseria, della loro abbiezione, del loro dolore!

$$
\begin{aligned}
& * \\
& * *
\end{aligned}
$$

E costoro, in Vicaria, non sono elettori: sono popolo. E un'altra cosa. È una folla di sventurati che sono nati con le mille eredità del morbo, della povertà e del vizio e per cui nulla e nessuno si mosse mai, perchè questi sventurati fossero, in nome di Dio, in nome della natura, considerati come fratelli, più infelici, più disgraziati, ma fratelli; sono sventurati; a cui nessuno pensò di dar pane e lavoro, poichè prima che il pane e il lavoro giungano sino ad essi, mille ladri eleganti lo debbono sottrarre o taglieggiare: sono sventurati a cui nessuno dà una scuola, poichè i signori del Comune delirano per gittare un milione, a una società che sta per fallire e non provvedono, a che le scuole sieno aperte: sono sventurati a cui il lavoro pesa, sulla vita, raro a trovarsi, difficile a durare, malissimo compensato, precario, incerto, irrisorio: sono sventurati che spesso, vengono dal crimine o ci vanno, ma non per colpa loro, per colpa di tutta un'altra società, cieca, sorda indifferente, dura come una roccia.

Non elettori! Popolo: popolo vero, folto, oscuro, a masse paurose, con volti ove si manifestano gli stenti e le tristezze, con voci roche, velate dalla fame e dalle malattie, con i germi ereditarii che un atavismo, ahi, di povertà, vi mise, con gli istinti del male esaltati dalla lunga esistenza di miserie, e di pianto, con l'inclinazione al male sì, al male, che vi pose questo centennale e crudele abbandono ostinato della loro truce sorte; e la Società infame si vela gli occhi per non vedere questo popolo, che fugge via, per obbliarne l'esistenza e crede che la fuga sia la salvezza. Oh voi non fuggiste, Cristo, Signore, questo popolo che, nel tempo dei tempi, era oppresso da ogni male e schiacciato dai possenti e dai protervi! Voi lo cercaste, dapertutto: ovunque vi fosse un misero, un sofferente, un peccatore, un malato, un criminale, voi gli tendeste la mano, lo abbracciaste, lo chiamaste figliuolo: voi lasciaste che la donna del male, emblema, di tutte le peccatrici, di tutte le criminali, si curvasse ai vostri piedi domandando perdono e perdonaste, in lei, tutti i peccati delle povere creature muliebri, fiacche, caduche, fragili, che la virtù non le sorregge.

Ah, non voi fuggite, questo popolo, o Leone Tolstoi, o il più cristiano fra $\mathrm{i}$ cristiani, voi che avete salutato come fratelli, solo quelli che soffrono, voi che avete rinfacciato alla società ipocrita e perversa tutti i suoi inganni e tutte le sue infamie, voi 
che siete sceso in mezzo a tutti i disgraziati e le disgraziate, e solo essi, nei vostri libri, salirono all'onore della vostra pietà e della vostra tenerezza. Padre del popolo, era il Signor Nostro Gesù: e padre fu ognuno che disprezzò i ricchi e i malvagi e che curò le piaghe fisiche morali degli infelici: e padre sarà chiamato, nella vita nostra, chi si curerà solo di asciugar le lacrime di chi piange, di sollevar le anime depresse, di ridare una coscienza morale a coloro che l'ebbero distrutta, dal loro destino. Questo nome di padre il popolo di Vicaria, lo ha dato ad Ettore Ciccotti, perchè egli non ha messo le mani sui suoi occhi, per non vedere l'orrore di quelle esistenze, perchè egli non è fuggito, via, compreso da un senso di terrore e d'impotenza: perchè egli è restato, coraggioso, paziente, indulgente, dove consolante, dove beneficante, dove cercando di rialzare lo spirito, dove soccorrendo il corpo: perchè, egli ha avuto pietà, ma non una pietà pomposa e oltraggiosa, non una pietà sterile e infeconda, ma una pietà umile e fraterna, ma una pietà efficace e operosa, ma una pietà civile e gentile. Mille volte, questo popolo di Vicaria obbliato, abbandonato, tradito, ha trovato in Ettore Ciccotti non l'ipocrita che mette mano al portafogli e dà due lire, e compera due lire di tranquillità di coscienza, ma un cuore paterno, pieno di quella celestiale indulgenza che è la forza dei soggiogatori del popolo, ma un'anima virile che, nell'istesso tempo, ha detto la parola che solleva e ha prestato l'opera che redime, che ha consolato il dolore e ha aperto gli spiriti alla speranza di una vita più cosciente e più civile. Non vi stupite se le donne violenti di Porta Capuana e le male donne di via Martiri d'Otranto lo adorino! Così la Maddalena adorò Cristo: così la Maslova, perduta e criminale, adorò Tolstoi. Il vincolo sociale è fondato sull'alta e nobile e riabilitante carità fraterna: il miracolo sociale, è creato solo da un sublime e ardente sentimento di pietà e di amore.

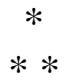

E che gli importa di esser deputato di Vicaria. a Ettore Ciccotti? L'uomo, in lui, è superiore a questa carica tenuta, spesso da gente vile o sciocca. La beltà della sua anima non soffre miscela di ambizione puerile: egli non è un arrivista: il socialismo non gli è servito per emergere: per cento altre forze intellettuali e morali, che sono in lui, egli sarebbe emerso. E non fu sempre socialista: e la sua storia della sua via di Damasco, tutta a onor, suo, è il romanzo di uno spirito retto e puro che si ribella, d'un colpo solo, alla infamia sociale, in tutti i ceti, infamia che non colpisce lui, ma chi sta intorno a lui: è la ribellione oscura e impetuosa di un altruista. 
Sia, sia, sempre il padre del popolo di Vicaria, Ettore Ciccotti! Non dimentichi questo popolo che egli ha amato, che lo ama: non lo abbandoni, di nuovo alla sua sorte tetra e truce: apporti, egli la luce della parola, la bellezza dell'esempio, la efficacia dell'azione a quella gente sventurata che, pure, è umana, è cristiana, ha i segni della intelligenza e del sentimento, nella persona. A ciò, non serve esser deputato. E, forse, domani, Ettore Ciccotti lo sarà di nuovo, se il giovine patrizio che ne prese il posto, non si decida, e forse è capace di farlo, a diventare, di Ettore Ciccotti, scolaro, cooperatore, fratello, in quartiere Vicaria. Il titolo di padre, è così bello, è così degno! Niuno che lo pronunzi, senza esserne commosso: ed in bocca a un popolo, esso significa preghiera e benedizione.

Napoli, Novembre del 1904

\section{UNA DONNA}

Avete mai provato il sottile e malinconico piacere, piene di segrete sorprese e d'intimi sussulti, di frugare fra $i$ vecchi ritratti in un antico albo di cui da anni, non si schiudeva il fermaglio, una polverosa cartella di cui, da tanto tempo non si scioglievano i nastri? Avete mai fissato gli occhi sui pallidi ritratti di colori che sono morti, poichè, misteriosamente, tutti i ritratti dei morti appaiono scolorati? Volti di morti, volti di persone scomparse, che, non rivedrete mai più, volti di creature che, forse vi amarono e che voi amaste male, forse, e, che non vi amarono a tempo, forse, volti già consunti dalla tristezza o floridi di una beltà quasi intangibile, volti di tanto vecchi ritratti, di persone che portarono via una parte del vostro cuore, che vi tolsero una luce dall'anima, forse, o che, forse, vi lasciarono un profondo e indelebile ricordo! Questo sottile piacere di scorrere con le dita trepide, fra gli antichi ritratti, dalla malinconia vi fa passare allo spasimo: e quando, sgomento dai fantasmi che voi stessi avete evocati, lasciate cader l'albo e chiudete la cartella, onde di amarezza seguitano a fluttuare nel vostro sangue. $\mathrm{O}$ passato, tu solamente sei vero! Ecco, io ho innanzi un tanto antico ritratto, di una donna: di una signora: è una fotografia, che avrà trent'anni, forse, e che fu data alla donna che degnamente, io ho più amata e venerata nel mondo, a mia madre.

Questo ritratto è di Teresa Ravaschieri e già in quel tempo in cui fu amichevolmente donato, non era un ritratto nuovo: veggo un viso ovale, sereno, sorridente, eminentemente giovanile; e dei bruni e folti capelli neri, ove si appoggia un diadema prezioso: un vestito da festa che scovre un collo e delle spalle statuarie, adorne di una collana ricchissima: una testa da cameo, infine, ove la purezza delle linee è animata dalla espressione più spirituale nella luce dei cari occhi larghi e limpidi, nel 
sorriso della bella bocca, in tutta la quiete viva e fresca della fisionomia. Il prezioso ritratto, dunque, mostra una Teresa Ravaschieri in tutta la pienezza della sua beltà e della sua grazia muliebre, quando la sua persona e il suo intelletto, il suo fascino e la sua cultura attiravano verso lei gli omaggi divoti d'italiani e di stranieri, quando il suo nome, illustre per tutti i suoi antenati, illustre per suo nonno, per suo padre, rappresentava, in Napoli, quello della vera gran dama, la gran dama per cui l'alta società napoletana, di allora, era veramente alta. Prezioso ritratto che ha fatto, che fa profondamente trasalire l'anima mia, che esalta, in un sogno di bellezza e di bontà la mia fantasia e che dà al mio cuore, che non sa obliare, con un nuovo fiotto l'inconsolabile rammarico, quello di non aver visto, l'anno scorso, trapassar l'anima grande di Teresa Ravaschieri, quello di non aver potuto, in gramaglia, seguire, a piedi, il suo corteo funebre, quello di non aver potuto baciare, piangendo, la pietra marmorea che chiude il suo sepolcro, come quello di una seconda madre.

Qual donna, mai, eguaglierà costei? Chi oserà mai fare quello che essa fece? La somma delle sue virtù morali non è, forse, grande quanto quella delle sue opere, non ha essa, forse, operato tutto il bene che ha pensato e che ha sentito? Chi mai realizzò un alto sogno di amore come ella volle e fece? Chi mai raggiunse uno scopo più lontano, più nobile e più puro, con la sola volontà del bene? Dove non giunse il suo desiderio di carità e dove non mise ella la testimonianza del suo desiderio soddisfatto? Che cosa ella non invocò sui poveri, sugli afflitti, sui derelitti e qual balsamo, per lei, non sanò le crudeli ferite di costoro? Balzano i ricordi belli, nella mia mente e Teresa Ravaschieri mi appare come in una selva di vivide rose fragranti, ed ognuna di esse è un beneficio, ognuna di esse è una carità, ognuna di esse è un atto di amore! Quante volte, al suo contatto spirituale, io sentii ringagliardire l'affievolita mia fede cristiana: poichè ella era una cristiana perfetta, umile senza cecità, tenera senza leziosaggine, speranzosa senza baldanza, fidente senza esitazione. Un giorno, parlavamo di Galilea, insieme, e del grande lago di Genesareth, ove Cristo sedò la tempesta, e della montagna di Hattine, ove Egli pronunciò l'inobliabile sermone: e gli occhi di Teresa Ravaschieri si riempirono di sogno e come in sogno, ella mi disse: senti, io son certa che se avessi avuto la fortuna di vivere là, in quei tempi, avrei seguito Gesù, dovunque, come le Marie: ed era vero, poichè la sua anima ardente era apostolica, poichè ella amava diffondere la sua fiamma vivida, e generatrice di vita dello spirito! Quante volte ella mi ha chiamata a sè per comunicarmi una sua idea schietta, provvida, generosa e io, come 
altri miseri esseri, con le mani e con le anime legate dall'incertezza e dalla debolezza, come tanti altri infelici che, guasti dal dubbio, temono di abbandonarsi alle imprese audaci, rischiose e magnifiche, le ponevo, miserabilmente, delle obbiezioni meschine sempre sgomentandomi delle complicazioni, in cui ella comprometteva la sua salute, la sua pace, il suo tempo. Ella crollava il capo: sorrideva: riconciliava il suo discorso, in cui tutto il suo progetto ideale di soccorso, di sussidio, di protezione appariva magicamente colorito: e a un tratto, io, come gli altri, eravamo colpiti dalla grazia, e innanzi a lei ci sentivamo stupiti e fiacchi, e sentivamo che una volontà alta e bella ci trascinava, e tutti eravamo travolti in un'onda di bene che, da lei emanava, che ci rendeva capaci di cento cose più forti di noi, che ci dava la forza di servirla, Teresa Ravaschieri, nei suoi miracoli di tenerezza che ci metteva dietro a lei, come discepoli di un Maestro divino. Ah Ella, sì, avrebbe seguito, col capo avvolto nel manto e i piedi nudi nei sandali, Gesù, per le altitudini del Thabor, per le pianure di Elsdrelon e per le balze della Samaria, fino a Gerusalemme, fino al Calvario, sin oltre il Calvario: ma alla sua parola di pietà, al suo sentimento di amore, a questa luce costante e generatrice di ogni bene che emanava da lei, ognuno di noi sarebbe con lei partito, dove ella volesse, con lei, ove ferveva il più crudele morbo, ove giacevano i morti del cataclisma, ove strideva il grido di guerra. Chi, chi mai dirà più a noi, come Teresa Ravaschieri la diceva, la parola che desta l'anima e che la sospinge alla divozione suprema? Chi più, chi più indicherà a noi, con la mano bianca e l'occhio scintillante, la via del sacrificio sublime? Ah che noi siamo soli, freddi, tristi e dubbiosi di ogni cosa e dubbiosi di ogni persona, e giammai, più udremo la voce che ci dava la forza di vivere, l'energia di vivere per gli altri, l'abnegazione di vivere per tutti gli altri, tutti, amici, indifferenti, estranei, nemici. Non è morta una donna, l'anno scorso, il dieci di settembre: si è dileguata la più incomparabile forza spirituale: è scomparsa la miglior parte di noi, quella che riassumeva le tre virtù dell'anima, la carità, la fede, la speranza: abbiamo perduto, con lei il segreto della nostra vita di cristiani operosi e di creature umane degne di questo nome, il senso della tenerezza fraterna, si è spento, in noi, poichè lei, l'Evocatrice, l'Animatrice di tutte le fraterne tenerezze, è spenta.

$$
\text { * }
$$

Giusto è che, oggi, in un tempio, i maggiori cittadini napoletani e le più pietose donne e quanti sono i più noti che amarono e ammirarono Teresa Ravaschieri, 
convengano per onorar la sua memoria e per pregar pace a lei. Tali feste funebri solenni, sono assai belle, e commoventi, anche. Ma se io penso che, in quel tempio, dovrebbero entrare tutti coloro che essa ha beneficati, esso è piccolo, troppo piccolo, infinitamente piccolo: la folla dei poveri, degli infelici, degli infermi, degli abbandonati, cui ella provvide di dignitosa elemosina, di ricovero, di sanità recuperata, di cure materne, la folla, a cui ella dette il suo amore e la sua fortuna, il suo tempo e la sua anima, la folla a cui ella dette sè stessa, in un lungo ed entusiasta olocausto, è immensa. Niun tempio la potrebbe contenere e ognuno di costoro, poichè gli oscuri, i derelitti non dimenticano, certo, ogni volta che il suo spirito si effonde nella preghiera, rammenterà il nome di Teresa Ravaschieri. Ed è, forse, più giusto domandare a Lei, dal suo eterno riposo che ella ci preghi pace: assai più giusto che noi, combattuti, trafitti, stanchi, oppressi, senza più guida nell'esistenza, chiediamo pace a Lei. Ella lottò e vinse, nel nome di Dio e nel nome della virtù d'amore che raccoglie tutta l'umanità. Assai prima di morire, ella era in pace. Ella aveva detto a Dio le parole estreme, assai prima di morire: e aveva avuto il dono della pace. È alla nostra nave pericolante, in gran tempesta, nella notte, che bisogna chiedere l'aiuto di uno spirito orante, nella beatitudine celeste: è al nostro naufragio che l'anima eletta deve dar soccorso, dal misterioso mondo delle anime. La grande anima aveva la consuetudine dei miracoli, per la forza della preghiera, e della bontà. Preghiamo che Ella continui!

Napoli, autunno 1904 


\section{Anexo 1}

Mapa de Nápoles em 1800 por John Stockdale

http://www.skyscrapercity.com/showthread.php?t=464004\&page $=5$ acessado em 20/07/2014

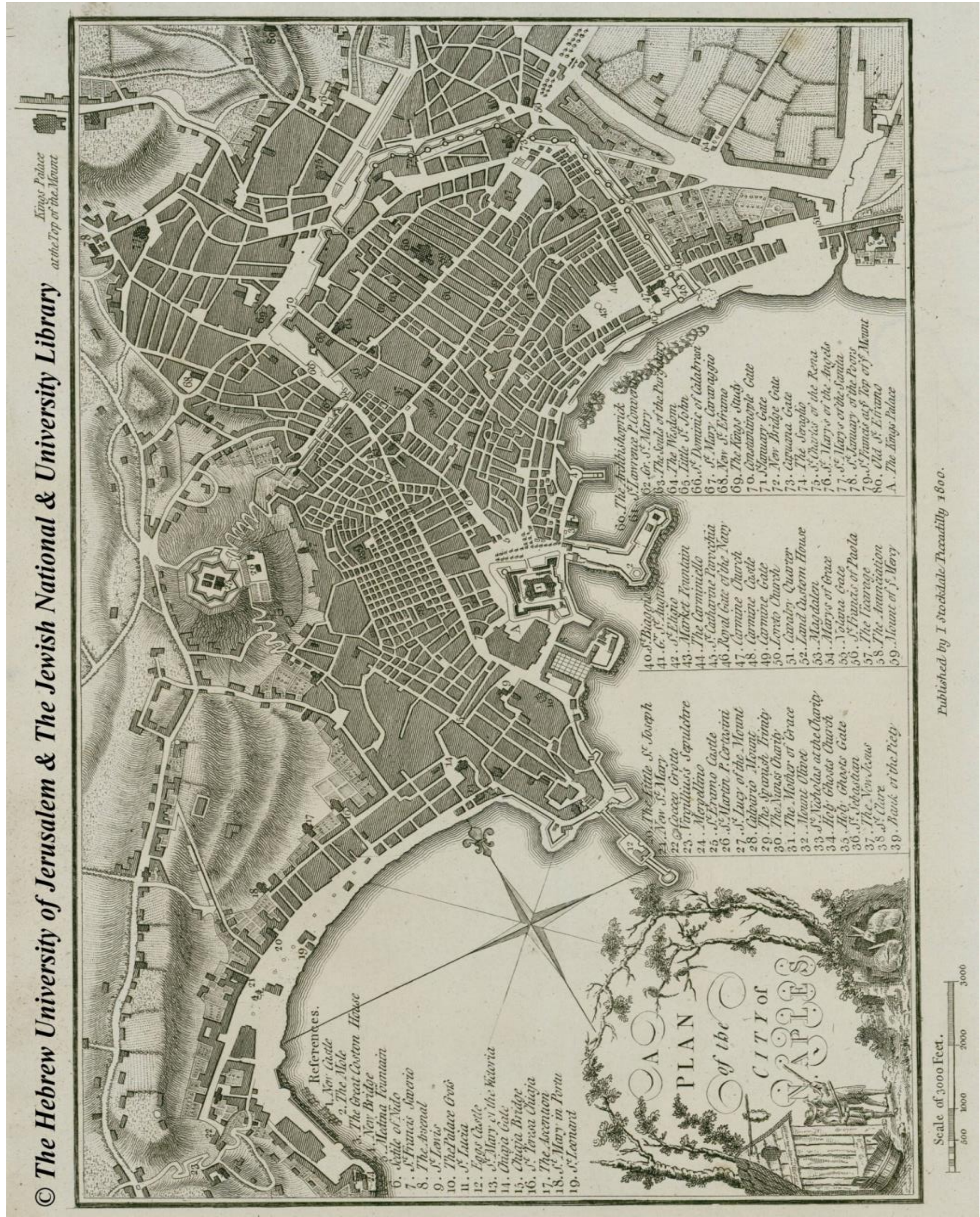




\section{Anexo 2}

Mapa atual do centro histórico de Nápoles http://www.smilecityitalia.net/alberghi/napoli/hotelnapoli/centro-storico/ acessado em 20/07/2014.

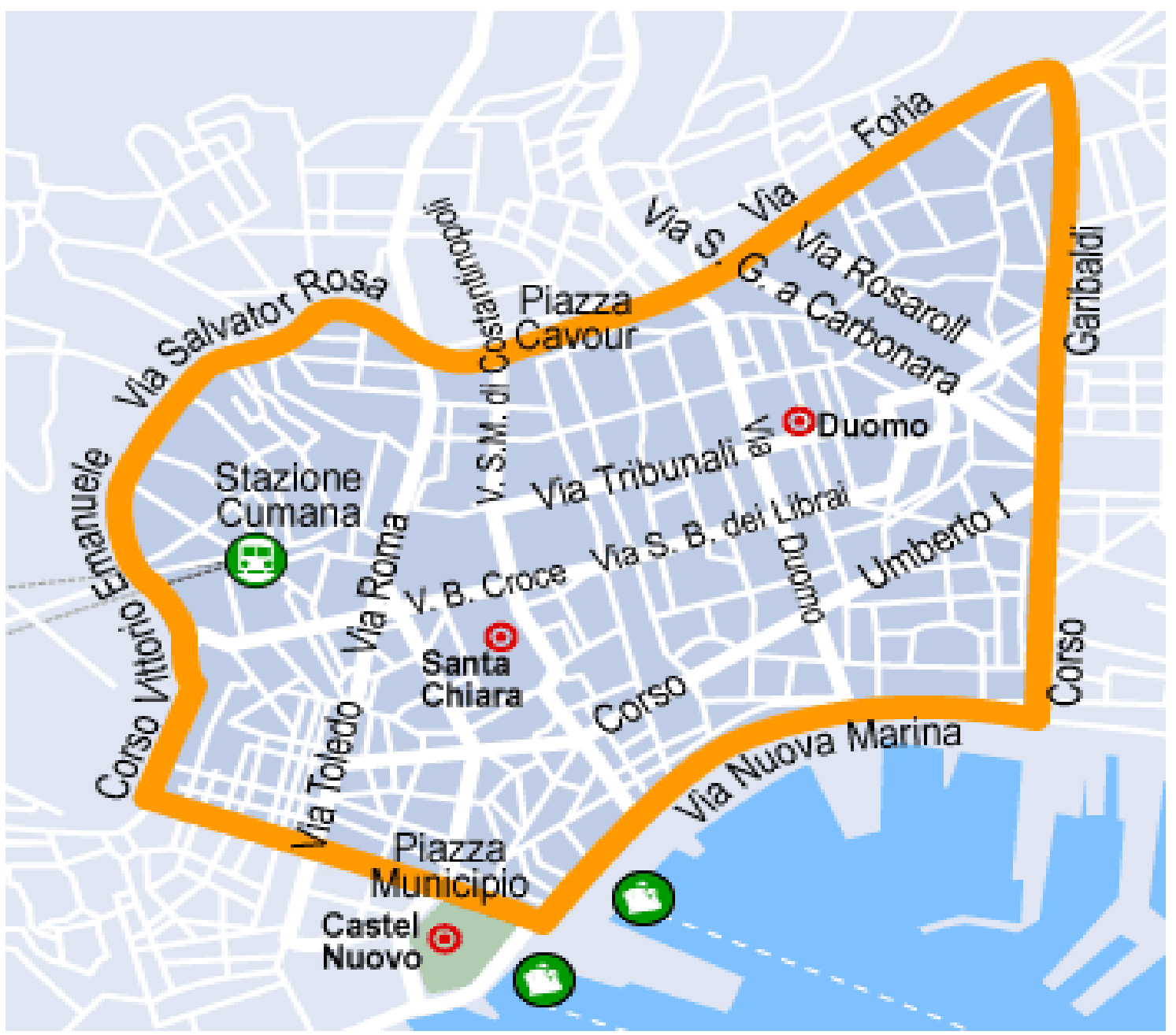




\section{Anexo 3}

Vincenzo Migliaro. "Vico Grotta e Vico Forno a Santa Lucia”. In: FARRUGIA, 2005, p.342.

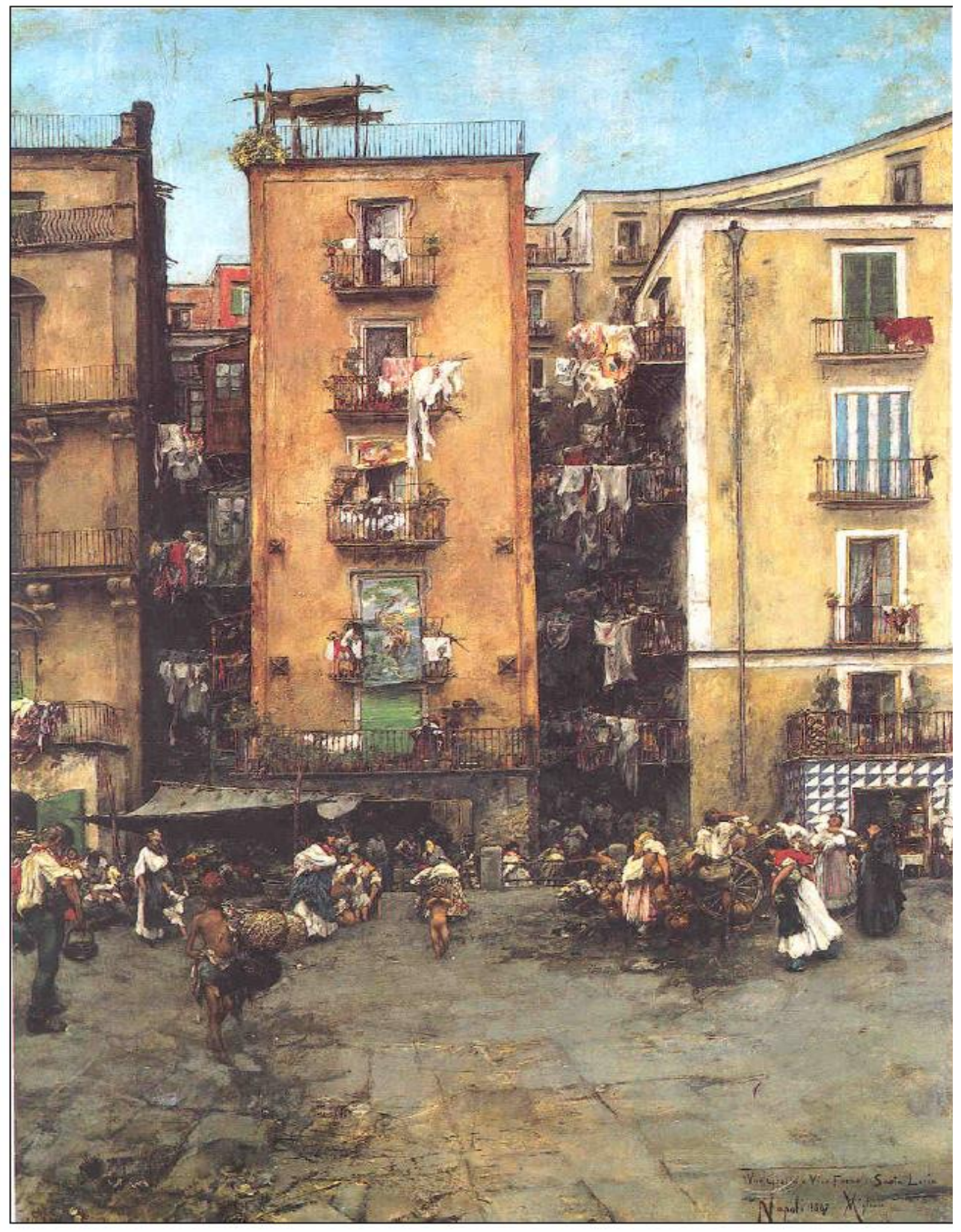




\section{Anexo 4}

Vincenzo Migliaro. "Vico Cannucce”. In: FARRUGIA, 2005, p.346.

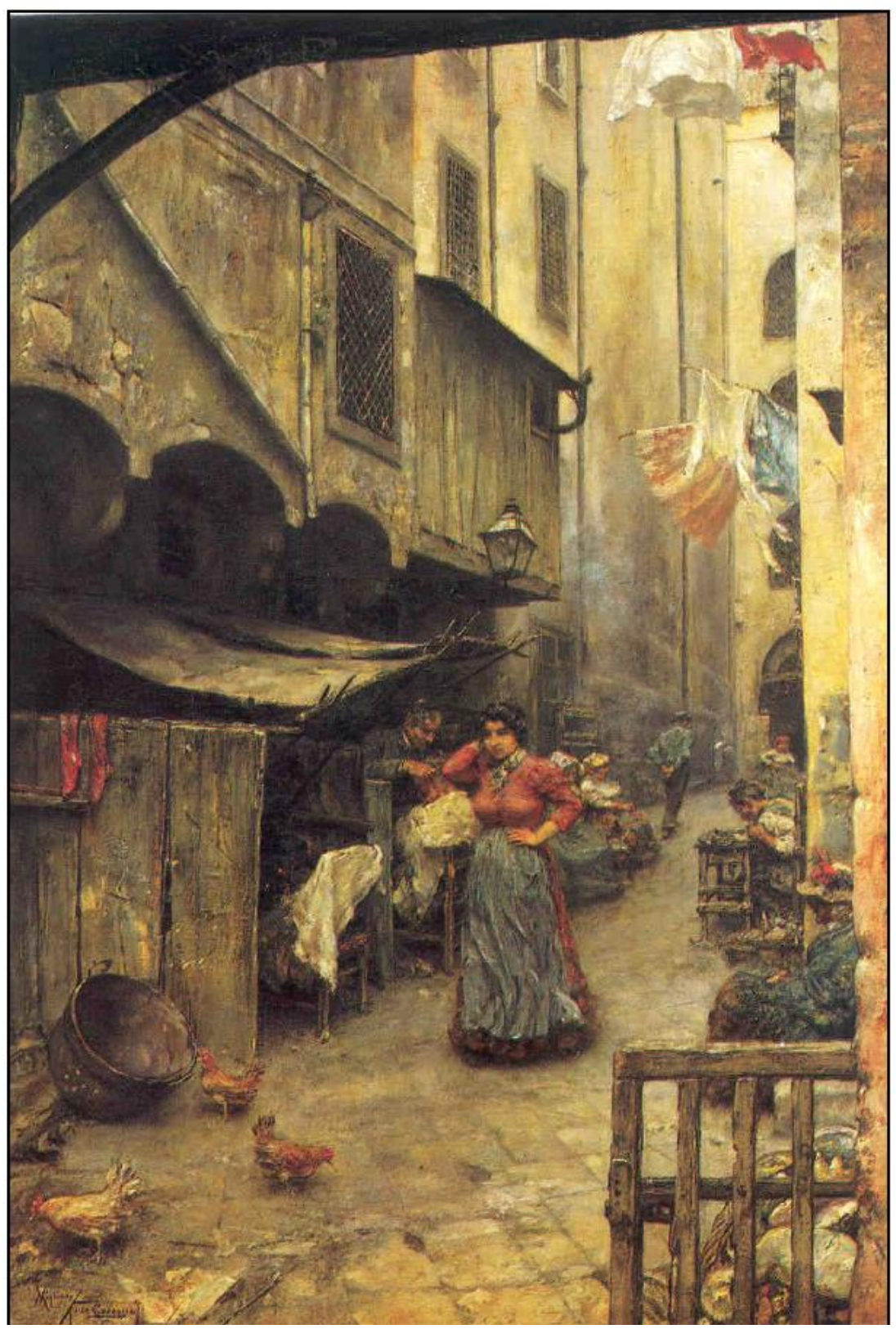




\section{Anexo 5}

Vincenzo Migliaro. "Strada di Porto". In: FARRUGIA, 2005, p.348

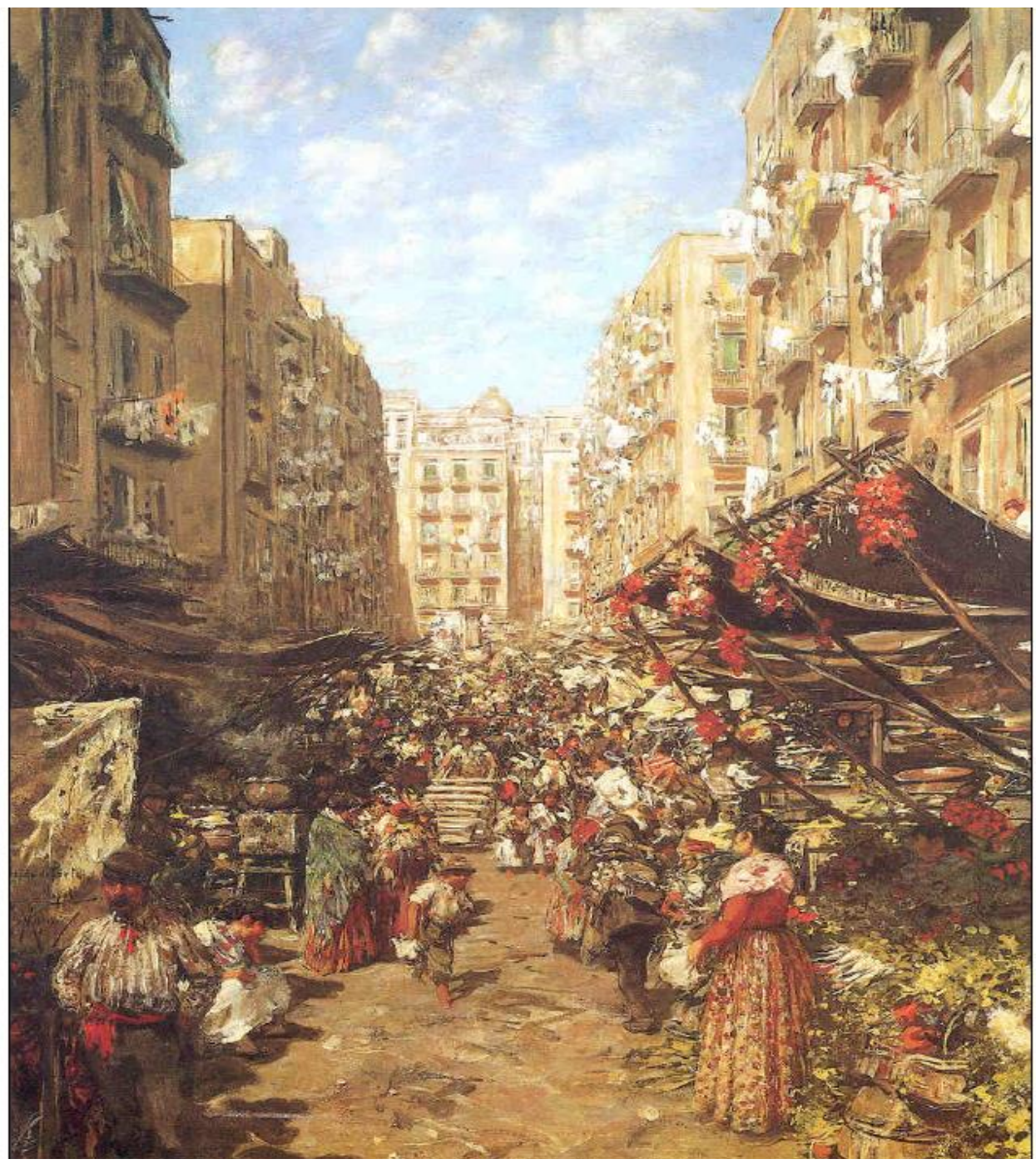




\section{Anexo 6}

Carlo Brancaccio. "Via Toledo" In: FARRUGIA, 2005, p. 394.

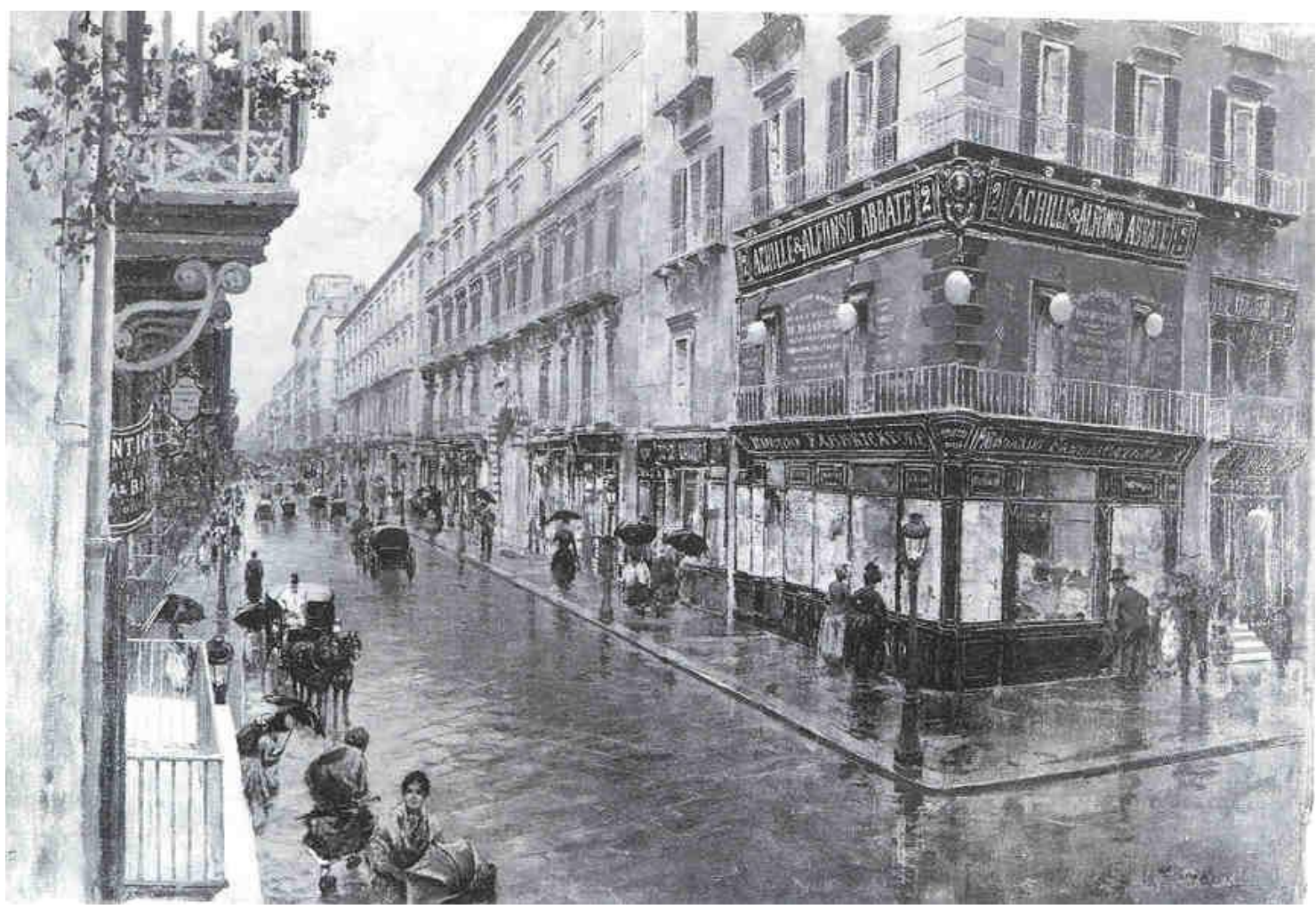

